Genetic control of methane emission, feed efficiency and metagenomics in dairy cattle 


\section{Thesis committee}

\section{Main supervisor}

Dr P. Løvendahl

Senior Researcher, Center for Quantitative Genetics and Genomics

Aarhus University, Tjele, Denmark

\section{Promoter}

Prof. Dr. H. Bovenhuis

Personal chair at Animal Breeding and Genomics

Wageningen University \& Research

\section{Thesis co-supervisors}

Dr J. Lassen

Researcher, Center for Quantitative Genetics and Genomics

Aarhus University, Tjele, Denmark

Dr Y. de Haas

Senior Scientist, Animal Breeding and Genomics

Wageningen University \& Research

\section{Other members}

Prof. Dr. J. Jensen, Aarhus University, Denmark

Prof. Dr. P. W. G. Groot Koerkamp, Wageningen University, The Netherlands

Dr. E. E. Connor, United States Department of Agriculture, USA

Prof. Dr. L. Lange, Danish Technical University, Denmark

This research was conducted under the joint auspices of the Graduate School of Science and Technology (GSST), Aarhus University and the Graduate School of Wageningen Institute of Animal Sciences (WIAS), Wageningen University and is part of the Erasmus Joint Doctorate Program "EGS-ABG". 


\title{
Genetic control of methane emission, feed efficiency and metagenomics in dairy cattle
}

\author{
Gareth Frank Difford
}

\section{Thesis}

submitted in fulfilment of the requirements for the joint degree of doctor between Aarhus University

by the authority of the Head if the Graduate School of Science and Technology

and

Wageningen University

by the authority of the Rector Magnificus, Prof.dr. A.P.J. Mol,

in the presence of the

Thesis Committee appointed by the Acadamic Board at Wageningen University and the Head of the Graduate School of Science and Technology at Aarhus University

to be defended in public

on Friday September 28, 2018

at 12 p.m. Foulum, Denmark 

Difford, G.F

Genetic control of methane emissions, feed efficiency and metagenomics in dairy cattle, 210 pages

Joint PhD thesis, Aarhus University, Denmark and Wageningen University, the Netherlands (2018)

With references, with summaries in English and Danish

ISBN 978-94-6343-328-0

DOI: https://doi.org/10.18174/458036 



\begin{abstract}
Difford, G.F (2018). Genetic control of methane emission, feed efficiency and metagenomics in dairy cattle

Joint PhD thesis, Aarhus University, Denmark and Wageningen University, the Netherlands
\end{abstract}

The dairy industry faces the challenges of increasing production, remaining economically viable whilst simultaneously minimising impacts on the environment. The cost of feed is the highest variable cost of milk production, thus, improved feed efficiency is a strong wish. However, $\mathrm{CH}_{4}$ is a potent greenhouse gas with an energy value estimated as $2-12 \%$ of the gross feed energy intake and thus represents a loss. There is, therefore, a need to identify the phenotypic and genetic relationships between efficiency of feed utilisation and $\mathrm{CH}_{4}$ production to ensure optimal breeding methods of increasing profitability and limiting environmental impact of dairy production.

Feed is degraded and $\mathrm{CH}_{4}$ is produced by rumen microbes and not by the cow. The mechanisms which influence the composition of the rumen microbial community and how they, in turn, influence the feed efficiency and $\mathrm{CH}_{4}$ production of the host, are not well understood.

Among the possible strategies, selective breeding has the benefit over others by being cumulative and persistent over generations. Genetic improvement through selection requires that phenotypes are recorded on large numbers of animals. Moreover, phenotypes must show variation, a portion of which must be genetic, and must have economic or societal value. Understanding the genetic co-variation behind and between these measures is crucial to simultaneous breeding for a more profitable and climate friendly dairy industry. However, the measurement of $\mathrm{CH}_{4}$ emissions, feed efficiency and the rumen microbiome under commercial conditions on a large scale is not a trivial task. The aim of this PhD project was to develop and integrate phenotyping measures for $\mathrm{CH}_{4}$ emission, feed efficiency and the rumen microbiome and to investigate their genetic potential for selective breeding.

Firstly, in Chapter 2, improvements where made to the sniffer method of $\mathrm{CH}_{4}$ breath concentration recording in dairy cattle during automatic milking. An algorithm was developed to efficiently detect and correct for variable and random drift in time series between instruments and to detect when the cow's head is out of the feed bin. Using linear mixed model methodology, repeated measures per cow were used to improve precision and control sources of inaccuracy such as sensor drift, background gas concentrations and diurnal variation, that were subsequently removed. Resultantly, highly repeatable phenotypes where obtained which 
demonstrated adequate agreement for the interchangeable use of two instruments. In Chapter 3, the ranking of cows under commercial conditions using the sniffer method was compared with the "gold standard" respiration chambers. Individual level correlations estimated as proxies for genetic correlations revealed a high correlation between sniffer-predicted $\mathrm{CH}_{4}$ production and $\mathrm{CH}_{4}$ production in the $\mathrm{RC}$. These findings offer a proof of concept that sniffer $\mathrm{CH}_{4}$ phenotypes recorded over a week of lactation show substantial promise as large scale indicator traits for $\mathrm{CH}_{4}$ production using RC.

In Chapter 4, genetic parameters were estimated between feed intake, milk production and $\mathrm{CH}_{4}$ breath concentration from sniffers over the course of the first lactation in Holstein cows in Denmark and The Netherlands. Through combining data between countries, genetic residual feed intake and breath gas concentrations were found to be significantly heritable, demonstrating that genetic improvement of feed efficiency and $\mathrm{CH}_{4}$ breath gas concentration is feasible in dairy cattle. The estimated genetic correlations from the largest dataset indicated that improved feed efficiency will also result in decreased gas emissions. Furthermore, including the breath gas concentrations in a multitrait genetic evaluation increased the accuracy of bull breeding values for gRFI, demonstrating an indirect economic value of $\mathrm{CH}_{4}$ and $\mathrm{CO}_{2}$ breath concentration phenotypes.

In Chapter 5, we estimated the relative abundance of rumen bacteria and archaea and found a portion of these to be heritable in dairy cattle. The results demonstrate that host additive genetics has an influence on the abundance of some rumen bacteria and archaea. We detected significant associations between certain bacterial genera and differences in $\mathrm{CH}_{4}$ production of the host cow, further contributing to knowledge of the underlying biological mechanisms driving $\mathrm{CH}_{4}$ production of the host. We further extended quantitative genetic methods to estimate rumen microbial kinships between cows in place of additive genetic relationships. This enabled the quantification of variation in host $\mathrm{CH}_{4}$ production explained by the rumen microbial composition, expressed in the new term 'microbiability', as the relative proportion of host variation explained by associated microbes. Crucially the microbiability and the heritability of dairy cattle $\mathrm{CH}_{4}$ production were largely independent. Thus, selective breeding for reduced $\mathrm{CH}_{4}$ production can be extended by methods perturbing the rumen microbiota towards reduced $\mathrm{CH}_{4}$ production.

In Chapter 6 (the general discussion), the value of method comparisons for phenotype development by comparatively quantifying sources of error between cheaper alternative methods and intensive gold standard methods was discussed. The primary constraint to breeding for improved feed efficiency and $\mathrm{CH}_{4}$ production remains the recording of feed intake on a large scale under commercial conditions 
and recording of "true" $\mathrm{CH}_{4}$ production. It was proposed that the accuracy of bull breeding values for both feed efficiency and $\mathrm{CH}_{4}$ production can be increased through the use of sniffer phenotypes in robot milking herds, using individual level correlations but a genetic correlation between sniffer phenotypes and $\mathrm{RC} \mathrm{CH}_{4}$ production are still needed. The records required for estimating genetic correlations with meaningful standard errors can only be achieved through substantial financial investments, development of cheaper alternative methods of phenotype recording or international collaborations.

Further to the general discussion, a portion of host phenotypic variation in $\mathrm{CH}_{4}$ production was found to be associated with the rumen bacterial and archaeal composition. However, research is needed to determine if microbial associations are causative and methods to direct desired changes in the rumen microbial composition are still needed to unlock the potential of this under-exploited resource. The methods developed for quantifying the microbial contribution to host phenotypic variation will be of value to inform research into complex microbial-associated phenotypes, such as diseases and digestion in dairy cattle, other livestock species and humans. This thesis therefore contributes to the understanding of the genetic variation in feed efficiency, methane emissions and rumen metagenome of dairy cows. 



\section{Resumé}

Mælkeproducenterne står over for udfordringer ved at øge produktionen, hvorvidt den forbliver økonomisk levedygtig samtidig med at miljøpåvirkningerne minimeres. Kostprisen ved foder er den højeste variable omkostning til mælkeproduktion, og derfor er forbedret fodereffektivitet et stærkt ønske. Metan $\left(\mathrm{CH}_{4}\right)$ er imidlertid en potent drivhusgas med en energiværdi anslået som 2-12\% af bruttoenergiindtaget og udgør således et tab. Der er derfor et behov for at identificere de fænotypiske og genetiske forhold mellem effektiviteten af foderudnyttelse og $\mathrm{CH} 4$-produktion for at sikre optimale avlsmetoder til øget Iønsomhed og begrænse miljøpåvirkning fra mælkeproduktionen.

Foderet nedbrydes og $\mathrm{CH}_{4}$ produceres af vom-mikrober men ikke af koen selv. De mekanismer, der påvirker sammensætningen af det vom-mikrobielle samfund, og hvordan de igen påvirker fodereffektiviteten og $\mathrm{CH}_{4}$-produktionen hos koen som vært, kendes ikke i tilstrækkeligt omfang.

Blandt de mulige strategier til at reducere klimaaftrykket har selektiv avl fordelene overfor andre ved at være kumulative og permanente over fremtidige generationer. Genetisk forbedring gennem udvælgelse kræver, at fænotyper registreres på et stort antal dyr. Desuden skal fænotyper vise variation, hvoraf en del skal være genetisk og skal have økonomisk eller samfundsmæssig værdi. At forstå den genetiske sam-variation bag og mellem disse egenskaber er afgørende for samtidig avlsarbejde mod en mere rentabel og klimavenlig mælkeproduktion. Måling af $\mathrm{CH}_{4}$-udledninger, fodereffektivitet og vom-mikrobiomet under kommercielle forhold i stor skala er imidlertid ikke en triviel opgave. Formålet med dette ph.d.projekt var at udvikle og integrere fænotypebestemmelser for $\mathrm{CH}_{4}$-emission, fodereffektivitet og vommikrobiomet og undersøge deres genetiske potentiale for selektiv avl. Resultaterne heraf er beskrevet i 4 af afhandlingens kapitler.

For det første, i kapitel 2, blev der foretaget forbedringer i forbindelse med sniffermetoden for $\mathrm{CH}_{4}$-åndedrætsmålinger hos køer under automatisk malkning. En algoritme blev udviklet til effektivt at finde og korrigere for drift i tidsserier mellem instrumenter og at udpege, når koens hoved er ude af fodertruget. Ved hjælp af en lineær mixed-model-metode blev gentagne mål pr. ko brugt til at forbedre præcision og reducere unøjagtighed, såsom sensordrift, baggrundskoncentrationer og døgnvariationer, der efterfølgende blev fjernet. Resultatet, i form af højt gentagelige fænotyper blev opnået, hvilket viste en god mulighed for at anvende data indsamlet fra to forskellige instrumenter. I kapitel 3 blev rangordningen af køer i private besætninger hvor $\mathrm{CH} 4$ er målt med sniffermetoden sammenlignet med "den gyldne standard" respirationskamre. Korrelationer på individuelt niveau blev beregnet som 
erstatning for genetiske korrelationer, og viste en stærk sammenhæng mellem sniffer $\mathrm{CH}_{4}$ produktion og $\mathrm{CH}_{4}$ produktion i RC. Disse resultater giver et bevis på, at sniffer $\mathrm{CH}_{4}$-fænotyper registreret over en uge med laktation viser et stort potentiale som storskala-indikatoregenskaber for $\mathrm{CH}$-produktion målt ved anvendelse af $\mathrm{RC}$.

I kapitel 4 blev genetiske parametre beregnet mellem foderoptagelse, mælkeproduktion og $\mathrm{CH}_{4}$-åndedræts-koncentration fra sniffere i løbet af den første laktation hos Holstein-køer i Danmark og Nederlandene. Ved at kombinere data fra begge lande blev genetisk residual foderoptagelse og åndedræts-koncentrationer fundet i væsentlig grad arvelige, hvilket viser, at genetisk forbedring af fodereffektivitet og $\mathrm{CH}_{4}$-koncentration er mulig hos malkekvæg. De beregnede genetiske korrelationer fra det største datasæt viste, at forbedret fodereffektivitet også vil resultere i faldende gasemissioner. Derudover øgede gaskoncentrationerne i en multiegenskabs-genetisk beregning nøjagtigheden af tyres avlsværdier for gRFI, hvilket demonstrerede en indirekte økonomisk værdi af fænotyper af $\mathrm{CH}_{4}$ og $\mathrm{CO}_{2}$ målinger.

I kapitel 5 vurderede vi den relative forekomst af vom-bakterier og -arkæer og fandt at en del af disse er arvelige hos malkekvæg. Resultaterne viser, at koen genetik, når den ses som vært har indflydelse på forekomsten af nogle vombakterier og archæer. Vi opdagede væsentlige sammenhænge mellem visse bakterielle slægter og forskelle i $\mathrm{CH}_{4}$-produktion fra værts-koen, hvilket yderligere bidrager til kendskab til de underliggende biologiske mekanismer, der bestemmer koens $\mathrm{CH}_{4}$ produktion. Vi videreudviklede de kendte kvantitative genetiske metoder til også at omfatte vommens mikrobielle slægtskab mellem køer udover de additivt genetiske forhold. Dette muliggjorde kvantificering af variation i værts- $\mathrm{CH}_{4}$-produktion forklaret af den vommikrobielle sammensætning udtrykt i den nye betegnelse 'mikrobiabilitet' som den relative andel af værtsvariation forklaret af tilhørende vommikrober. Mikrobiabiliteten og arveligheden af $\mathrm{CH}_{4}$ produktion var stort set uafhængig. Selektiv avl til reduceret $\mathrm{CH}_{4}$-produktion kan således udvides ved fremgangsmåder, der påvirker mikrobiomet mod reduceret $\mathrm{CH}_{4}$ produktion. I kapitel 6 (den generelle diskussion) blev værdien af metode-sammenligninger diskuteret $\mathrm{i}$ forhold til fænotyper ved kvantificerede fejlkilder hos billigere alternative metoder og intensive "guldstandard" metoder. Den primære begrænsning for avl for forbedret fodereffektivitet og $\mathrm{CH}_{4}$ produktion forbliver målinger af foderoptagelsen i stor skala under kommercielle forhold og registrering af "sand" $\mathrm{CH}_{4}$ produktion. Det blev foreslået, at nøjagtigheden af tyre-avlsværdier for både fodereffektivitet og $\mathrm{CH}_{4}$-produktion kan øges ved brug af snifferfænotyper i robotmalkebesætninger ved brug af individuelle niveaukorrelationer, men der er stadig brug for en genetisk korrelation mellem snifferfænotyper og $\mathrm{RC} \mathrm{CH}_{4}$-produktion. De indsatser der kræves 
til vurdering af genetiske korrelationer med meningsfulde standardfejl, kan kun opnås gennem betydelige finansielle investeringer, udvikling af billigere alternative metoder til fænotypemålinger eller internationale samarbejder. I forlængelse af den generelle diskussion viste det sig at en del af den fænotypiske variation i $\mathrm{CH}_{4}$ produktion hænger sammen med vom-bakterielle og arkæiske sammensætning. Imidlertid er der behov for yderligere forskning for at bestemme, om mikrobielle sammenhænge også er årsags-sammenhængende, og der er behov for metoder til at styre ønskede ændringer i den vom-mikrobielle sammenhæng for at udnytte potentialet for denne underudnyttede ressource. Metoderne udviklet til kvantificering af det mikrobielle bidrag til værts-fænotypisk variation vil være af værdi for videre forskning i komplekser mellem mikrobielle fænotyper, såsom sygdomme og fordøjelse i mælkekvæg, også hos andre dyrearter og mennesker. Denne afhandling bidrager derfor til forståelsen af den genetiske variation i fodereffektivitet, metanemissioner og vom-metagenom af malkekøer. 



\section{Contents}

$7 \quad$ Abstract

11 Resumé

$171-$ General introduction

$57 \quad 2$ - Interchangeability between methane measurements in dairy cows assessed by comparing precision and agreement of two non-invasive infrared methods

793 - Rapid Communication: Ranking cows' methane emissions under commercial conditions with sniffers versus respiration chambers

954 -Can greenhouse gases in breath be used to genetically improve feed efficiency of dairy cows?

1295 - Host genetics and the rumen microbiome jointly associate with methane emissions in dairy cows

$1616-$ General discussion

201 Acknowledgements

205 Curriculum Vitae

213 Colophon 



\section{1}

General introduction 



\subsection{Rational for research}

Dairy cattle and other livestock industries face the challenges of increasing production, remaining economically viable whilst simultaneously minimising impacts on the environment. According to a projection by the FAO, global food production needs to increase by approximately $70 \%$ to meet the needs of 9.7 billion people by 2050 (UN, 2015). Milk, being a complete source of fat, protein, lactose, vitamins and minerals, must further increase by roughly $80 \%$ by 2050 (Steinfeld et al., 2006). The natural resources to sustain expansion to meet these demands are finite as seen by total global cultivated land remaining largely constant since 1991 (O'Mara, 2012). Additionally, increases in milk production are associated with greater greenhouse gas emissions like methane and carbon dioxide, as well as greater feed intake. Accordingly, research into a more sustainable and profitable dairy industry by improving production efficiency whilst limiting environmental impact is becoming increasingly relevant to the producer and consumer. Specifically, research to mitigate the rising variable costs of feed by increasing feed efficiency and to decrease the environmental impact by reducing greenhouse gas (GHG) emissions and nutrient losses to the environment (Connor et al., 2013).

Methane $\left(\mathrm{CH}_{4}\right)$ is a potent greenhouse gas (GHG) with a climate change potential 32 times greater than carbon dioxide $\left(\mathrm{CO}_{2}\right)$ (Holmes et al., 2013) and an atmospheric half-life of 12 years, which is substantially shorter than $\mathrm{CO}_{2}(>100$ years)(IPCC, 2014). Therefore, reducing $\mathrm{CH}_{4}$ emissions from anthropogenic-related sources has been identified as a key area for mitigating climate change with immediate effects (Gerber et al., 2013; IPCC, 2014). Livestock accounts for $14.5 \%$ of anthropogenic-related $\mathrm{GHG}$ emission of which enteric $\mathrm{CH}_{4}$ emissions from ruminants directly accounts for $5.8 \%$ (3). The $\mathrm{CH}_{4}$ produced by dairy cattle and other ruminants is a natural by-product of enteric fermentation of high fibre feedstuffs by microbial enzymatic activity (Janssen and Kirs, 2008). Enteric fermentation results in the production of volatile fatty acids (VFA) (predominantly, acetate, propionate and butyrate) which is used as an energy resource by the cow (Moss et al., 2000; Martin et al., 2010). The production of acetate and butyrate releases metabolic hydrogen which is converted to $\mathrm{H}_{2}$ by hydrogenase-expressing bacterial species, whereas the production of propionate consumes $\mathrm{H}_{2}$ (Moss et al., 2000). An accumulation of dissolved $\mathrm{H}_{2}$ reduces the efficiency of carbohydrate degradation and microbial protein synthesis (McAllister and Newbold, 2008). Hydrogenase-expressing bacteria convert metabolic hydrogen from anaerobic fermentation into $\mathrm{H}_{2}$ which is then converted to $\mathrm{CH}_{4}$ via methanogenesis and finally leaves the rumen (McAllister and 
Newbold, 2008). Furthermore, $\mathrm{CH}_{4}$ has a caloric value approximately $2-12 \%$ of the gross energy intake (GEI) which represents a net loss of energy to the cow (Johnson and Johnson, 1995). Thus, enteric methanogenesis is a pathway for maintaining optimal conditions for ruminal fermentation but is also a potential indicator of energy loss and consequently production inefficiency.

Feed plays a crucial role in economic and environmental performances of dairy production units, as the cost of feed comprises the largest variable cost of dairy production ( $44 \%$ on average globally), but can be as high as $84 \%$ in some countries (Hemme et al., 2014). Furthermore, the composition of the feed affects not only the price but also the $\mathrm{CH}_{4}$ emitted. The primary income of dairy production is from milk and milk prices are volatile often failing to increases with feed prices, a situation over which the producer has limited control. A promising strategy to increase profitability is to reduce costs through retaining cows, which require less feed (input) to give contemporary levels of production (output) (i.e. increase feed efficiency). The quantity of feed consumed is directly proportional to the $\mathrm{CH}_{4}$ produced (Yan et al., 2010). Therefore, cows that require less feed to produce the same level of production as their contemporaries are expected to produce less $\mathrm{CH}_{4}$ in absolute terms (Waghorn and Hegarty, 2011). However, the organic matter composition of the feed, particularly fibre, also affects the $\mathrm{CH}_{4}$ emissions at the individual cow level (Hristov et al., 2013) as well as the entire production chain (Møller et al., 2014). Empirical studies on digestibility and digesta passage rate have associated deceased $\mathrm{CH}_{4}$ yield per kg of milk with reduced diet and poor cell wall digestion (CabezasGarcia et al., 2017), indicating that cows which are poor at extracting energy from fibre produce less methane. A greater understanding of the relationships between feed intake, feed efficiency and $\mathrm{CH}_{4}$ production is therefore needed to ensure concomitant increases in feed efficiency and limiting environmental impact.

The majority of enzymatic processes within the rumen such as cellulases to degrade cellulose and hemicellulose, as well as methyl-coenzyme $\mathrm{M}$ reductase to produce $\mathrm{CH}_{4}$, are encoded for in the genomes of the microorganisms inhabiting the rumen and not the host. The rumen is a highly specialised organ which provides an anaerobic environment hospitable to microorganisms and promotes the acquisition of commensal microbes. The relationship between ruminant host and rumen microbe has evolved over approximately 50 million years, to the extent where host cannot survive without the microbes and some of the rumen microbes cannot survive outside of the rumen. This partnership has been highly successful, leading to ruminants adapting and thriving in some of the harshest and most widely distributed environments, on high fibre diets which are mostly indigestible to many other domains of life. Increasingly, results are showing that the host may directly or 
indirectly exert some influence over the rumen microbial composition (Weimer et al., 2010; Roehe et al., 2016). Differences in rumen microbial communities have been associated with differences in $\mathrm{CH}_{4}$ emissions in sheep (Kamke et al., 2016) and feed efficiency in cattle (Hernandez-Sanabria et al., 2010; Hernandez-Sanabria et al., 2012; Carberry et al., 2012; Jewell et al., 2015). However, how the host and rumen microbiota interact to influence host phenotypes is not currently known, thus the link between causation and association is still lacking.

Although dairy cattle production has shown substantial increases in efficiency in the preceding decades, through improvements to individual milk yield as a result of advances in nutrition, genetics, and animal health, this was achieved in the absence of direct information concerning feed efficiency, $\mathrm{CH}_{4}$ emission or the rumen microbiome (Capper et al., 2013; Hill et al., 2015). Thus, by considering this information it may be possible to further improve efficiency while reducing the environmental impact of dairy cattle production. Genetic improvement has the benefit of cumulative gains over generations, which are persistent as opposed to short-term transient nutritional, or managerial strategies. However, genetic improvement requires that phenotypes be recorded on a large number of animals, preferably under the commercial conditions in which they are expected to perform. Furthermore, the traits of interest must be variable, a portion of the variability be heritable and have an economic or societal value. The studies above suggest that methane emissions and feed efficiency are linked through feed intake and the influence of the host and its rumen microbiome. Should these phenotypes be recorded on large numbers of related animals under commercial conditions, genetic investigations can determine the potential for breeding for these phenotypes.

\subsection{Biological considerations of methane emissions in dairy cattle}

An understanding of the underlying biology of $\mathrm{CH}_{4}$ emissions in dairy cattle precedes that of recording systems and genetic evaluations. The release of $\mathrm{CH}_{4}$ from the animal is primarily through three routes: first, through eructation directly from the rumen; second, $\mathrm{CH}_{4}$ is absorbed from the rumen and hindgut into the blood and exhaled through the lungs and third, $\mathrm{CH}_{4}$ is emitted from the hindgut as flatulence. In cattle and in sheep, it has been estimated using radiolabeled $\mathrm{CH}_{4}$, that approximately $98 \%$ of $\mathrm{CH}_{4}$ is expired through the breath and eructation and only $2 \%$ from flatulence (Murray et al., 1976). This has implications for the methods of measuring $\mathrm{CH}_{4}$ emitted by a cow as, although $98 \%$ is expired in the breath and 
eructation, recording only part of the emission (expiration vs flatulence) is not necessarily the same as measuring the entire emission (expiration and flatulence) (Muñoz et al., 2012). This is particularly true if there is animal variation in the proportions emitted through the three different routes, which could impacted by differences in digestibility.

The rate at which $\mathrm{CH}_{4}$ is emitted changes throughout the day and from day to day and as such, the cow is in a continually changing biological state in terms of $\mathrm{CH}_{4}$ emission. The within day diurnal variation is affected by the feeding behaviour, diet and feeding allowance and pattern (Crompton et al., 2010; Bell et al., 2018). The simplest way to avoid diurnal variations in principle is to record $\mathrm{CH}_{4}$ emissions for every second of the entire $24 \mathrm{hr}$ period to get the true daily $\mathrm{CH}_{4}$ emission. In practice few methods sample or record continually throughout a $24 \mathrm{hr}$ period and thus rely on an average estimate which is subject to experimental error. The number of measurements and timing of sampling required to obtain a representative sample of the daily $\mathrm{CH}_{4}$ emission will vary depending on multiple factors such as feeding time, feeding behaviour, feed intake and activity (eating, ruminating etc) (Hegarty, 2013). One approach is to sample throughout the day, over multiple consecutive days and take an average estimate or moving average (Arthur et al., 2017) or model the time of day (Lassen et al., 2012; van Engelen et al., 2018) and in this manner the effects of diurnal variations are reduced or removed.

The rate of $\mathrm{CH}_{4}$ emission also changes from day to day (Grainger et al., 2007), according to physiological state (growing, lactating and non-lactating) (Ricci et al., 2013), within lactation (early, mid, peak and late) (Rischewski et al., 2017), and from lactation to lactation. It is important to understand the phenotypic and genetic relationships between methane emissions recorded at different points in time during an animal's life to better understand the implications for selection based on $\mathrm{CH}_{4}$ emission recorded at a particular point in time, in order to optimise recording strategies.

\subsection{Methods: Evolution of individual methane recording methods}

Numerous methods of recording $\mathrm{CH}_{4}$ emission on individual dairy cattle in vivo are available, each with its own set of advantages, disadvantages and scope of application (Hammond et al., 2016a). The gold standard method is indirect calorimetry in respiration chambers which has been in use for more than 100 years (Krogh, 1916). As the gold standard for $\mathrm{CH}_{4}$ emission and other respiratory gases, 
respiration chambers $(\mathrm{RC})$ are regarded as the most accurate and precise method from which other methods are benchmarked. As will be discussed in detail below, $\mathrm{RC}$ are costly, time consuming, labour intensive and not necessarily representative of all environmental conditions. Not surprisingly, numerous technologies are under development which may be cheaper, less invasive, easier to implement, or have a wider scope of application than the gold standard method. This is evidenced by frequent reviews (e.g. Patra, 2012; Storm et al., 2012; Hammond et al., 2016; Hill et al., 2016). However, the relative accuracy, precision and linear association between alternative methods and the gold standard needs to be assessed to determine the relative value and equivalence or lack thereof, between the gold standard and the alternative method (Barnhart et al., 2007).

All methods measure the $\mathrm{CH}_{4}$ concentration and other gases often using infrared (IR) spectroscopy. The gold standard then converts this to $\mathrm{CH}_{4}$ emission rate (or flux) in litres or grams per day by recording active air flow during measurement (Gardiner et al., 2015). Three main emission phenotypes frequently used in dairy cattle are: first, methane production as $\mathrm{CH}_{4}$ emission rate (or flux) in $\mathrm{L} / \mathrm{d}$ or $\mathrm{g} / \mathrm{d}$; second, methane yield per unit of feed intake (e.g. $\mathrm{CH}_{4}$ production per kilogram dry matter intake (DMI)) and third, methane intensity per unit product (e.g. $\mathrm{CH}_{4}$ production per kilogram energy corrected milk yield (ECM)). It is clear that the latter two phenotypes are the quotient of $\mathrm{CH}_{4}$ production and other phenotypes recorded independently of the method recording $\mathrm{CH}_{4}$. Unless otherwise specified, $\mathrm{CH}_{4}$ emission within this thesis will refer to the first phenotype, the direct measurement of methane expressed as $\mathrm{CH}_{4}$ concentration or $\mathrm{CH}_{4}$ production. Different methods of recording $\mathrm{CH}_{4}$ emissions have been comprehensively reviewed by Hammond et al., (2016) to which the reader is directed for further details. However, a brief summary of available methods and considerations directly pertaining to genetic evaluations are necessary and further discussed below.

\subsubsection{Respiration chambers as the 'gold standard'}

Respiration chambers using indirect calorimetry are extremely diverse in cost, operation, design and complexity (Global Research Alliance, 2012). The basic principle is that animals are confined to airtight or near airtight chambers for a period of 24 hours or more. Air is actively circulated through the chamber, the airflow rate along with the concentration of gases going into and leaving the chamber are recorded. Methane production is determined as the product of airflow rate and the difference in methane concentrations between inflowing and outflowing air. Further corrections are made for the volume of gases using the known gas densities at 
standard temperature and pressure as well as humidity. Some respiration chambers make further corrections based on recovery tests.

$$
Q_{c(i)}=\left(\left[\mathrm{CH}_{4}\right]_{M(i)}-\left[\mathrm{CH}_{4}\right]_{B(i)}\right) \times C_{p(i)} \times Q_{\text {air }} \times 10^{6}
$$

Where $Q c(i)$ is the $\mathrm{CH}_{4}$ emission in Litres per time point (i), the concentration of $\mathrm{CH}_{4}$ measured is denoted by subscript $M$, the concentration of background $\mathrm{CH}_{4}$ is denoted by $B, C p(i)$ is the fractional capture rate at time $i$ and Qair is the volumetric air flow rate in litre per time point (i). Using the temperature and atmospheric pressure recorded at time point (i) it is possible to convert $\mathrm{CH}_{4}$ from volume to mass using the ideal gas law. Summing $Q c$ (i) over a 24 hour period results in $\mathrm{CH}_{4}$ production in litres per day or grams per day is the ideal gas law conversion is made.

Although, respiration chambers are regarded as the gold standard and thus, by definition are the most accurate and precise measure of gas production, they have two main sources of error which can affect accuracy and precision. These are the airflow rate (Qair) or ducting efficiency $(\mathrm{Cp})$ through the chamber and the mixing of gases within the chamber, which are jointly reflected in the response time (Hammond et al., 2016a). In a joint calibration procedure of respiration chambers in the UK, high within- and between-chamber and facility variation was observed, with airflow rate and chamber mixing at $15.3 \%$ and 3.4\%, respectively (Gardiner et al., 2015). If the absolute accuracy of $\mathrm{CH}_{4}$ release rate of the test gas is known with certainty and is constant over time, the recovery rate can be used as a correction factor to adjust measurements. In the UK study, after correction for differential recovery rates was made, the combined uncertainty between chambers and facilities was reduced to $2.1 \%$ (Gardiner et al., 2015). The use of correction factors is discouraged and good practice is to identify the source of error and correct it (McLean and Tobin, 1987). With some authors calling for the publishing of recovery tests pre- and post-experiment as a prerequisite for publication (Gerrits et al., 2018).

A further factor to consider is that confinement within a chamber can stress animals and alter their feeding behaviour resulting in a drop in DMI, the largest driver of $\mathrm{CH}_{4}$ emissions; this has led many to question the extrapolation of these results to commercial conditions particularly grazing systems (Pinares-Patiño et al., 2013). Some developments in respiration chamber methods have led to animal friendly chambers constructed from cheaper transparent materials, lowering the cost and invasiveness of the method with minimal disruption to the accuracy and precision of the measurement and showing no drop in the DMI of cows under confinement (Hellwing et al., 2012). 
The throughput and capital cost of respiration chambers is the biggest challenge towards usage in genetic evaluations. Assuming a single day of acclimation and 2 consecutive days of recording, a single chamber can record $\mathrm{CH}_{4}$ production on 120 cows a year. In practice, this is likely to be far less (30-50) a year, as was reported in the only large scale genetic evaluation of $\mathrm{CH}_{4}$ emission in 1042 growing angus steers and heifers (Donoghue et al., 2016a). This cohort of cattle demonstrates that $\mathrm{CH}_{4}$ production is repeatable $(\mathrm{t}=0.97$ ) over consecutive days (Donoghue et al., $2016 \mathrm{~b}$ ), heritable $\left(\mathrm{h}^{2}=0.27 \pm 0.07\right.$ ) (Donoghue et al., 2016a) and achieves moderate genomic prediction accuracies of $0.32 \pm 0.04$ (Hayes et al., 2016). However, no such large cohort studies have been reported for dairy cows in RC.

\subsubsection{The Sulphur hexafluoride tracer gas technique}

The Sulphur hexafluoride $\left(\mathrm{SF}_{6}\right)$ technique has been in use for two decades and was originally developed to record $\mathrm{CH}_{4}$ emission of animals whilst grazing in paddocks or on pasture (Johnson et al., 1994). The principle behind this method is that $\mathrm{CH}_{4}$ production can be measured if $\mathrm{SF}_{6}$ gas emission rate from the rumen is known and employed as a tracer gas. Small permeation tubes containing $\mathrm{SF}_{6}$ with a predetermined release rate are placed into the rumen of test animals. The $\mathrm{SF}_{6}$ gas is mixed with the rumen-produced gases and exhaled and eructed through the mouth and nostrils. Test animals are fitted with gas sampling apparatus consisting of a halter, to support capillary tubing inlets in close proximity to the mouth and nostrils, and connected to an evacuated canister under vacuum. Exhaled air is sampled continuously through capillary tubing with in-line flow restrictors for 24 hours or usually longer. The $\mathrm{CH}_{4}$ and $\mathrm{SF}_{6}$ contained within the canister is determined as a batch sampled over single or multiple days using gas chromatography. Daily $\mathrm{CH}_{4}$ emission is calculated using the ratio of background corrected $\mathrm{CH}_{4}: \mathrm{SF}_{6}$ the previously determined rate of release from the permeation tubes to give an estimate of $\mathrm{CH}_{4}$ production (Williams et al., 2011)(eq 2):

$$
R C H_{4}=R S F_{6} \times \frac{\left[\mathrm{CH}_{4}\right]_{M}-\left[\mathrm{CH}_{4}\right]_{B}}{\left[S F_{6}\right]_{M}-\left[S F_{6}\right\rfloor_{B}} \times \frac{M W C H_{4}}{M W S F_{6}} \times 1000
$$

Where $\mathrm{RCH}_{4}$ is the release rate of $\mathrm{CH}_{4}$ in grams per day, $\mathrm{RSF}_{6}$ is the predetermined release rate of $\mathrm{SF}_{6}$ tracer gas from the permeation tubes $(\mathrm{mg} / \mathrm{day})$. The measured concentrations of $\mathrm{CH}_{4}$ and $\mathrm{SF}_{6}$ are given with subscript $M$, the recorded background gas concentrations are given by subscript $B$ and the molecular weights are denoted by $M W$ and multiplied by the constant 1000 to obtain units in grams per day. 
The $\mathrm{SF}_{6}$ method has been compared to $\mathrm{RC}$ in a number of studies and has been found to differ in accuracy in the range of ( 3 - $8 \%$ ) which can, in part, be due to true method differences and also $\mathrm{CH}_{4}$ emitted as flatulence which is not captured by the $\mathrm{SF}_{6}$ method (Grainger et al., 2007; Muñoz et al., 2012). Only a single study has compared the precision of the two methods and found the coefficient of variation (CV) within animal to be marginally higher with the $\mathrm{SF}_{6}(\mathrm{CV}=6.1 \%)$ versus $\mathrm{RC}(\mathrm{CV}=$ $4.3 \%)$, when this is expressed as repeatability $(\mathrm{t})$, the $\mathrm{SF}_{6}$ was slightly less repeatable $(t=0.27)$ than the $R C(t=0.30)$ (Muñoz et al., 2012). The primary sources of inaccuracy and imprecision are variations in the release rate of $\mathrm{SF}_{6}$ from permeation tubes which decays over time. One method of correction is to model the rate of release using Michaelis-Menten kinetics (Moate et al., 2015). Another source of error is the rate of sampling from capillary tubes as flow restrictors. Deighton et al. (2014) detected that $16 \%$ inaccuracy was due to variation in sampling rate. This lead to the development of orifice plate flow controllers to reduce error in sampling flow rates (Deighton et al., 2014). The $\mathrm{SF}_{6}$ method is also reliant on accurate estimation of background gas concentrations which need to be relatively low in comparison to recording concentrations (Berndt et al., 2014). Williams et al. (2011) estimated that the method of background estimation can influence the accuracy of the $\mathrm{SF}_{6}$ methods by approximately $6 \%$ and recommends the use of 'sentinel' canisters for sampling purely background gas concentrations. Further recommendations are made for outdoor, indoor and mixed use of the $\mathrm{SF}_{6}$ methods (Berndt et al., 2014).

Large-scale genetic evaluation of $\mathrm{CH}_{4}$ emissions in dairy cattle is feasible using the $\mathrm{SF}_{6}$ method and is well suited to testing animals under grazing conditions. Limitations to the throughput of the method are the numbers of apparatus available and the labour and capacity of laboratory facilities recording captured gases in the canisters. The minimum recommended recording time is 5-7 consecutive days in groups of animals 15 or larger (Berndt et al., 2014) which would culminate in approximately 750 cattle per year. Studies have shown the $\mathrm{SF}_{6}$ method to be highly repeatable over $5-10$ days $(t=0.86$ ) (Arbre et al., 2016). To date, only a single study has reported heritability estimates for $\mathrm{CH}_{4}$ production with $\mathrm{SF}_{6}\left(h^{2}=0.33 \pm 0.15\right)$ which realised phenotyping on approximately 100 cows per year (Breider et al., 2018).

\subsubsection{The GreenFeed system}

The GreenFeed ${ }^{\circledR}$ (C-Lock Inc., Rapid City, South Dakota, USA) is a patented standalone automatic head chamber system where a concentrate feeder is fitted with a ventilation hood. During visits to the unit to consume concentrate, the exhaled and eructed gases are spot sampled by recording $\mathrm{CH}_{4}$ concentration, head 
position and airflow rate (Zimmerman, 2011; Huhtanen et al., 2015). A radio frequency identification system (RFID) allows for the investigator to control the frequency and timing of visits to the unit - for a detailed description see Hristov et al. (2015b). Measurements are short (3-7 min per visit) and made multiple times a day over a period of multiple, consecutive days. Visitation to the unit is voluntary and requires training and adaption to the unit. Daily $\mathrm{CH}_{4}$ emissions $(\mathrm{g} / \mathrm{d})$ are estimated using volumetric airflow rate adjusted to standard temperature and pressure in a manner analogous to respiration chambers (Huhtanen et al., 2015; Jonker et al., 2016):

$Q_{c(i)}=\sum_{i}^{n} V_{i} \times\left(\left(\left[\mathrm{CH}_{4}\right]_{M(i)}-\left[\mathrm{CH}_{4}\right]_{B(i)}\right) \times \frac{1}{C_{p(i)}} \times Q_{\text {air }} \times 10^{6}\right) / \sum_{i}^{n} V_{i}$

Where $\mathrm{Qc}(i)$ is the $\mathrm{CH}_{4}$ emission in litres per day, the concentration of $\mathrm{CH}_{4}$ measured is denoted by subscript $M$, the concentration of background $\mathrm{CH}_{4}$ is denoted by $B, V_{i}$ is the visit time, $C_{p(i)}$ is the fractional capture rate at time $i$ and $Q_{a i r}$ is the is the volumetric air flow rate in L/(i). The weighted average is found by summing the product in parenthesis and visit time $\left(V_{i}\right)$ and dividing my the summartion of $V_{i}$ for all visits of each cow (n). Using the temperature and atmospheric pressure recorded at time point (i) or over the period $\left(i-i_{n}\right)$, it is possible to convert $\mathrm{CH}_{4}$ from volume to mass using the ideal gas law.

The GreenFeed system has been compared to RC and has shown mixed results for agreement, with poor concordance $(C C C=0.1$ ) in dairy cattle (Hammond et al., 2015) but high concordance in beef cattle (CCC $=0.84$ ) (Velazco et al., 2015). In most studies, the accuracy was not significantly different from that of the RC, but the GreenFeed had higher variation and was less precise (Velazco et al., 2015; Jonker et al., 2016; Rischewski et al., 2017). Typical sources of imprecision for the GreenFeed include the duration and number of visits. In a study optimizing recording procedures using the GreenFeed, it was found that setting a minimum visit time threshold of 3 minutes and 30 visits per animal showed a significant $72 \%$ reduction in variance as compared to visits 2 minutes in length (Arthur et al., 2017). Since the diurnal variations in $\mathrm{CH}_{4}$ emission vary throughout the day and animals visit the GreenFeed voluntarily, the timing and number of visits affect the accuracy and precision of the method. Some studies report as few as $1.3-2.6$ visits per animal per day and failed to detect diurnal variation or treatment effects with the GF which were detected with other methods (Hammond et al., 2015; Arthur et al., 2017). Conversely, other studies report $3.4-4.4$ visits per animal per day and detected 
significant treatment and diurnal variations (Jonker et al., 2016; Waghorn et al., 2016). The number and duration of visits need to be considered when estimating daily $\mathrm{CH}_{4}$ production in order to account for diurnal variations. Some studies have used weighted average as in equation 3 above (Jonker et al., 2016), whilst others have used a moving average (Arbre et al., 2016; Arthur et al., 2017) or modelled repeated measures using statistical methods (Arthur et al., 2017). Thus, careful control is required of the operator to ensure adequate visitation to the unit and timing of the visits to ensure adequate statistical power of the method.

The capture rate, $\mathrm{Cp}$, is another potential source of error and presumed to be 1 in equation 3 above. However, the influence of wind speed is shown to decrease the capture efficiency to $85 \%$ of static conditions and increase the variability three fold (Huhtanen et al., 2015). Hence, recommendations have been made for corrections to the capture efficiency for outdoor and potentially indoor use of the GreenFeed system (Huhtanen et al., 2015). One of the primary drawbacks of the GreenFeed system is that animals need to be trained to visit the unit. Whilst animals that have been trained will readily use the unit in subsequent experiments (Velazco et al., 2017), some animals will never use the unit (Hammond et al., 2016). This animal-instrument interaction has implications for the design and balance of treatments and the screening of animals in genetic evaluations.

Manufacturer specifications recommend 15 to 25 animals per GreenFeed unit and 30 or more visits are recommended per animal, which can be achieved in 720 days depending on the frequency of visits (Arthur et al., 2017). If all animals visit the unit adequately, throughput per unit is likely to be 750 to 1,300 animals per year. Repeatability estimates for $\mathrm{CH}_{4}$ production using the GF system are high $(\mathrm{t}=0.77$ 0.78) over 7-20 days (Arbre et al., 2016). Despite adequate numbers for genetic analysis in beef cattle $(n=616)$ (Arthur et al., 2017) and dairy cattle $(n=713)$ (Hristov et al., 2018), the only heritability estimate reported is from a combined data analysis using GF and sniffers with the eructation method on 769 Holstein cows $\left(h^{2}=0.26 \pm\right.$ 0.07) (Biscarini, 2016).

\subsubsection{Breath sampling methods: 'sniffers'}

'Sniffers' or the sniffer method was originally developed for sampling hydrocarbon gases such as $\mathrm{CH}_{4}$ from marine liquid samples and using nondispersive infrared (NDIR) analysers to detect increasing concentrations near marine petroliferous and gas seeps (Dunlap et al., 1960). The term was somewhat erroneously applied to the recording of $\mathrm{CH}_{4}$ concentration using NDIR in the breath of dairy cattle, to distinguish the method from those discussed above (Pinares-Patiño et al., 2013) but is now commonly used and understood. The principle behind sniffers 
is to sample the breath of individual dairy cows either during automated milking or visits to concentrate feeders when the cow's head is placed in the feed bin in close proximity to a gas sensor inlet (Madsen et al., 2010; Garnsworthy et al., 2012; Negussie et al., 2016). The appeal of this method is that it can record $\mathrm{CH}_{4}$ concentrations (and other gases) on many animals, without disrupting animal behavior or farm management practices. The method is in formative stages of development and as yet, has not standardized protocols or best management practices, with a wide variety of experimental setups and sensors in use (Garnsworthy et al., 2012; Lassen et al., 2012; Negussie et al., 2016; Pszczola et al., 2017). Two methods are predominantly used for the conversion or estimation of $\mathrm{CH}_{4}$ production using sniffer methods, which differ in their sources of error and will be discussed below. The first method is the eructation peaks method described in Garnsworthy et al. (2012) and the second is the $\mathrm{CO}_{2}$ tracer gas method (Madsen et al., 2010). Both methods are short-term sampling methods and are thus subject to potential sources of error, such as diurnal variations discussed in the GF system above and method specific errors, which will be discussed below.

The Eructation Peaks method: This method follows a similar approach to $\mathrm{RC}$ and GF but with very low passive air sampling rates, namely $1 \mathrm{~L} / \mathrm{min}$ described in equation 4 below:

$$
Q_{c}=\left(P_{f} \times\left[\mathrm{CH}_{4}\right]_{B C} \times \frac{1}{\delta} \times Q_{e x}\right) \times 57.2+252
$$

Where $Q c$ is the $\mathrm{CH}_{4}$ production in grams per day and $P_{f}$ is the frequency of eructation events. $\left[\mathrm{CH}_{4}\right]_{\mathrm{BC}}$ is the mean background corrected $\mathrm{CH}_{4}$ concentration, calculated by taking the integral of $\mathrm{CH}_{4}$ concentration during a peak minus the $\mathrm{CH}_{4}$ concentration at the start of a peak. The symbol $\delta$ is the mean recovery efficiency and $Q_{e x}$ is the efficiency of breath sampling which is assumed to be 1 . The term within parenthesis is referred to as the methane emission rate, MERm in Garnsworthy et al. (2012). The entire term in parenthesis is multiplied by a regression coefficient 57.2 and adjusted for the intercept 252 from an orthogonal regression calibration function described in Garnsworthy et al. (2012). This method was found to correlate well ( $r=0.89$ ) with subsequent measurements in the RC for 12 Holstein-Friesian cows (Garnsworthy et al., 2012). The concordance between the sniffer and RC using the same 12 cows used to generate the calibration equation was high (CCC $=0.88$ ) (Garnsworthy et al 2016, personal communication). Although these results suggest good agreement between the two methods, in practice, the variability of sniffers using the eructation peaks method is far larger (CV = 27-67\%) (Garnsworthy et al., 
2012; Bell et al., 2014) than those reported for RC (CV = $3-34 \%$ ) (Grainger et al., 2007; Yan et al., 2010).

Potential sources of error which can increase variation (imprecision) include variable wind conditions and sampling distance due to cow head movement, which will influence the recovery efficiency $(\delta)$ (Huhtanen et al., 2015; Wu et al., 2018). Systematic errors which could affect accuracy include variation in cow exhalation rate, which will influence the efficiency of breath sampling $\left(Q_{e x}\right)$ (Wu et al., 2018) and inter-barn or inter-sampling point variation in air velocity and ventilation, which systematically changes accuracy between locations due to changes in recovery efficiency $(\delta)$. Furthermore, the calibration function generated from 12 cows explained $89 \%$ of the variation in $\mathrm{CH}_{4}$ production between cows in the $\mathrm{RC}$, with the certainty around the intercept $252 \pm 21.4$ S.E. and the regression coefficient $57.2 \pm 9.5$ which can affect both accuracy and precision of the method (Garnsworthy et al., 2012).

Sniffers using $\mathrm{CO}_{2}$ tracer gas method: The approximation of $\mathrm{CH}_{4}$ production using breath concentrations recorded by sniffers follows a similar approach to that of the $\mathrm{SF}_{6}$ method above. The ratio of $\mathrm{CH}_{4}$ to $\mathrm{CO}_{2}$ breath concentrations is recorded during milking and the predicted $\mathrm{CO}_{2}$ production, based on other animal characteristics, is used as a tracer gas. The equation is shown in 5 below:

$$
Q_{C}=\mathrm{PCO}_{2} \times \frac{\left[\mathrm{CH}_{4}\right]_{M}-\left[\mathrm{CH}_{4}\right]_{B}}{\left[\mathrm{CO}_{2}\right]_{M}-\left[\mathrm{CO}_{2}\right]_{B}}
$$

Where $Q_{c}$ is the estimated $\mathrm{CH}_{4}$ production $\mathrm{L} /$ day and $P C O_{2}$ is the predicted $\mathrm{CO}_{2}$ production using a prediction equation (Madsen et al., 2010). The measured concentrations of $\mathrm{CH}_{4}$ and $\mathrm{CO}_{2}$ are given with subscript $M$ and the recorded background gas concentrations are given by subscript $B$. Using the temperature and atmospheric pressure recorded at measurement, it is possible to convert $\mathrm{CH}_{4}$ from volume to mass using the ideal gas law.

The $\mathrm{CO}_{2}$ ratio method using sniffers installed in concentrate feeders together with a prediction equation based on metabolisable energy intake, is shown to be highly correlated $(r=0.80)$ and concordant $(C C C=0.70)$ with RC in 22 Finnish Ayrshire cows (Negussie et al., 2016). Potential sources of error are the same for this method as for sniffers using the eructation peak method and short-term spot sampling methods. A method specific source of error is the predicted $\mathrm{CO}_{2}$ used as a tracer gas, any cow specific bias, inaccuracy or imprecision in this prediction equation will affect the final 
estimate for $\mathrm{CH}_{4}$ production. In a study using 157 records of Danish Holstein cows from multiple experiments and diets it was reported that the predicted $\mathrm{CO}_{2}$ using the ECM, BW and days carried calf (DCC) was largely underestimating the relationships between $\mathrm{CO}_{2}$ production and ECM (Hellwing et al., 2013). As a result, the final estimation of $\mathrm{CH}_{4}$ production showed a high correlation $(r=0.74)$ but a significant systematic drop in accuracy of $147 \mathrm{~L} \mathrm{CH}_{4}$ /day. A principle shortcoming of the current prediction equations for $\mathrm{CO}_{2}$ production as a tracer gas is the unaccounted effects of mobilisation of fat particularly in early lactation (Madsen et al., 2010). There is a risk that a cow mobilising a substantial amount of body fat will have a low measured $\mathrm{CH}_{4}$ to $\mathrm{CO}_{2}$ ratio but an over predicted $\mathrm{CO}_{2}$ production and the resultant effects on the estimated $\mathrm{CH}_{4}$ production are not known.

The greatest advantages of sniffer methods is the high throughput, portable and non-invasive nature of the sampling, which is limited only by the number of animals visiting the automatic milking station or concentrate feeder. This allows for: 1) recording of $\mathrm{CH}_{4}$ under commercial farm conditions without altering natural behaviour. 2) Provides the possibility for continuous recording over longer periods of time, resulting in full within- and over lactation recording. 3) The cost effectiveness of some sniffers offers the possibility for rapid upscaling by permanently installing sensors in robotic milking herds and concentrate feeders. A single sniffer gas analyser can phenotype 2000 - 3000 cows per year. Lassen and Løvendahl (2016) recorded $\mathrm{CH}_{4}$ emission on 3121 cows over two summer periods in milking robot herds in Denmark. Methane production using the eructation peak method in AMS is repeatable over 7-10 days ( $t=0.89$ )(Bell et al., 2014) and the $\mathrm{CO}_{2}$ ratio method in AMS milking visit $\left(t=0.34\right.$ ) (Lassen et al., 2012) and the $\mathrm{CO}_{2}$ ratio method using concentrate feeders ( $t=0.40-0.46$ ) over lactation (Negussie et al., 2016). Methane production using the $\mathrm{CO}_{2}$ ratio technique in AMS is shown to be heritable for measurements over 7 days $\left(h^{2}=0.21-0.25\right)$ (Lassen and Løvendahl, 2016; Lassen et al., 2016; Zetouni et al., 2018) and over the entire lactation $\left(h^{2}=0.27\right.$ \pm 0.09 ) (Pszczola et al., 2017). Furthermore, the direct measurement of $\mathrm{CH}_{4}$ concentration in AMS per milking is shown to be heritable $\left(h^{2}=0.11 \pm 0.02\right)$ (van Engelen et al., 2018). The heritability of $\mathrm{CH}_{4}$ production using the eructation peak method and the GF combined was reported as ( $\left.h^{2}=0.26 \pm 0.07\right)$ (Biscarini, 2016).

It is clear that all methods have inherent problems, but some methods like $\mathrm{SF}_{6}$ and sniffers are more amenable to genetic evaluations in certain production systems as is evidence by heritability estimates in literature. Depending on the intended use of the method, a balance can be reached between accuracy, precision and correlation of a method and the number and duration of visits per cow and the number of cows. 


\subsection{Efficiency of feed and energy utilization in dairy cattle}

In contrast to $\mathrm{CH}_{4}$ emissions, research into genetic variation in feed efficiency of dairy cattle has a long history of research (Mason et al., 1957; Veerkamp et al., 1995) but implementation in current breeding indices is limited (Pryce et al., 2015). This was preceded by research using direct calorimetry to determine energy contents of feed, faeces and urine (Kellner, 1909), as well as indirect calorimetry (i.e. respiration chambers) which identified the relationships between heat production and gaseous exchange (Brouwer, 1965). This allowed for the quantification of the difference between gross energy (GE) (energy indigested in feed) and faecal energy into digestible energy (DE). Furthermore, the recording of gas emission (including $\mathrm{CH}_{4}$ emission) and urine energy allowed for further partitioning of DE into metabolisable energy (ME), which further partitions into net energy for maintenance, production and heat increment of feeding. This enables the determination of net energy of feeds and the devising of energy requirements of animals upon which many of the net energy systems are based (Van Es, 1978; Volden, 2011).

A key finding is that the digestibility of feeds (ratio of ME to $D E$ ) is, to a very small extent, influenced by between cow differences but, to a large extent, the composition of feeds (Cabezas-Garcia et al., 2017). However, variation in the partitioning of ME into different biological functions (energy sinks) such as milk production, growth, accretion of body fat reserves, maintenance of body tissue, activity and reproduction requirements have been observed between cows and diets (Bauman et al., 1985; Veerkamp and Emmans, 1995). Detecting a genetic component to these partial energy efficiencies is limited due to low throughput of calorimetric methods (Korver, 1988; Veerkamp and Emmans, 1995). Directing changes in the partial energy efficiencies towards promotion of energy sinks of economic value (i.e. milk production) relative to other energy sinks is the very definition of feed efficiency. Nonetheless, great improvements in energy partitioning to milk production have been realized in dairy cattle through selective breeding for milk yield without knowledge of genetic variation in partial efficiencies or feed intake phenotypes (Capper et al., 2009). This is due to the 'dilution of maintenance' where high producing dairy cows partition greater portions of ME to milk production than maintenance relative to low yielding cows of comparable size (Bauman et al., 1985; Connor et al., 2012). As feed intake and milk yield are highly genetically correlated, a biological limitation to improving feed efficiency through selection is expected, as digestibility of feed decreases in cows that consume higher levels of feed (in 
multiples of maintenance requirements) (Vandehaar et al., 2016). Resultantly, the effectiveness of improving feed efficiency by selecting for increased milk yield only will be diminished. Therefore, further genetic improvement of feed efficiency requires direct measurement of feed intake on larger numbers of related individuals under commercial conditions in order to identify cows with high milk yield relative to feed intake and other energy sinks.

\subsubsection{Recording of individual feed intake}

In practice, feed efficiency is a not a directly observable metric; rather, it is feed intake relative or conditional on production traits (Jensen et al., 1992). Not surprisingly, with such a broad definition, there is a wide variety of phenotype definitions (Berry and Pryce, 2014) but common to all of which is feed intake records. Likewise, feed intake phenotypes can vary greatly in dairy cattle. The simplest measure is the mass of feed intake ( $\mathrm{kg} /$ day) converted to $\mathrm{DMI}(\mathrm{kg} / \mathrm{day})$ to remove variation in moisture content of feeds. As the energy contents of feed varies greatly, this can be converted to GE (MJ/day) and to DE (MJ/day) based on predicted digestibility of feedstuffs but the use of these phenotypes are more limited in genetic evaluations (Van Arendonk et al., 1991).

Recording of DMI was initially conducted by offering individual cattle in tie stalls feed at a $5-10 \%$ refusal rate and manually weighing refusals periodically (Nielsen et al., 2003; Zom et al., 2012). This approach is time- and labour-consuming, with limited phenotyping throughput, as well as altered animal behaviour by restricting mobility. The gold standard method for recording individual cow DMI is with RFID access gates and automatic feed bins which records the mass of feed consumed at each visit which is summed for a 24 hour period (Tolkamp and Kyriazakis, 1997). This method facilitates recording of group housed animals without restrictions to mobility and limited changes to behaviour. Validation experiments have found deviations in specificity (cow is not present in feed bin but is detected) (87-99.8\%) and sensitivity (cow is present in feed bin and detected) (99.2-99.9\%) of the RFID transponders (DeVries et al., 2003; Bach et al., 2004; Chizzotti et al., 2015). Furthermore, differences in accuracies between automated bins and manual weighing ranging from 120 - 600 grams a day have been reported (DeVries et al., 2003; Chapinal et al., 2007; Chizzotti et al., 2015). Additionally, negative values were recorded after a cow has visited the feed bin and not consumed any feed as well as cows observed pushing feed out of the feed bin (Chapinal et al., 2007) and stealing behaviour between cows (Bossen and Weisbjerg, 2009). None of the validation studies reported correlations or concordance between methods but on the basis of sources of error listed above, deviations from 1 in the ranking of animals are 
expected. Regardless, automated feed bins have increased throughput of DMI recording in research and specialised herds to the point of facilitating multinational genetic investigations into DMI (Berry et al., 2014).

Despite these sources of error, records of DMI on individual cows are highly repeatable within lactation ( $t=0.66$ with a range $0.46-0.84$ ) (Sondergaard et al., 2002; Berry et al., 2014; Tempelman et al., 2015) and over lactation (Veerkamp et al., 2013). Furthermore, DMI is heritable $\left(h^{2}=0.34 .5\right.$ with a range $0.11-0.58$ ) (Koenen and Veerkamp, 1998; Berry et al., 2014) and the heritability varies over lactation (Manzanilla Pech et al., 2014; Li et al., 2017). Lastly, DMI is highly genetically correlated to milk production ( $\mathrm{rg}$ ranging from $0.20-0.73$ ) but none of the estimated correlations are high enough to suggest indirect selection using milk production alone would be sufficient for improving feed efficiency (Spurlock et al., 2012; Manzanilla Pech et al., 2014).

\subsubsection{Metabolic efficiency of lactating dairy cattle}

Calorimetric methods have identified two sources of efficiency: one, maintenance efficiency i.e. improving milk production relative to energy required to maintain body tissue and two, metabolic efficiency i.e. more efficient partitioning of energy toward milk production and other traits of economic and energetic importance. As smaller body size has lower maintenance requirements, improving maintenance efficiency is readily achieved by the addition of selection against body size to a breeding goal, which already selects for improved milk production (Pryce et al., 2015). On the other hand, improving metabolic efficiency is more challenging as it requires expressing feed intake independent of maintenance requirements and other energy sinks.

The definitions of feed efficiency phenotypes currently under investigation can be broadly categorized into ratio- or residual-based traits (Kennedy et al., 1993). Inherent deficiencies in ratio traits have been thoroughly discussed elsewhere (Veerkamp and Emmans, 1995; Connor et al., 2012) and will only be briefly addressed here. Ratio based traits, like gross feed efficiency (milk production/feed intake), fail to take into account variation in other energy sinks that are not explicitly included in the calculation. Critically, ratio traits are not genetically independent of the component traits and are rarely linearly associated with component traits (Sutherland, 1965). Ratio traits consequently cannot distinguish between maintenance efficiency and metabolic efficiency. Not surprisingly, including biased correlations based on non-linear relationships into a selection index results in suboptimal or unpredictable response to selection (Gunsett, 1984; Zetouni et al., 2017; Shirali et al., 2018). 
Residual based traits are a form of a restricted selection index where DMI is phenotypically or genetically independent on production traits or energy sinks (Kennedy et al., 1993). The most widely used method of estimating residual feed intake is using a phenotypic multiple regression of production traits on DMI and extracting the random residuals called phenotypic residual feed intake (RFIp). This method, in essence, removes the phenotypic variation between DMI and production traits and thus, the phenotypic correlations between DMI and production traits are expected to be zero but genetic correlations may deviate from zero (Veerkamp et al., 1995; Huttmann et al., 2009; Shirali et al., 2018). Extension to this two-step method are the single step RFIp models, which can account for heterogeneity between research stations and different dietary rations (Tempelman et al., 2015). This phenotype is shown to be repeatable within lactation ( $t=0.46-0.90)$ (Connor et al., 2013; Tempelman et al., 2015; Byskov et al., 2017) as well as over lactations (t $=0.20$ ) (Connor et al., 2013). Furthermore, it is heritable $\left(h^{2}=0.02-0.25\right)$ (Pryce et al., 2014; Tempelman et al., 2015) and also changes over lactation (Li et al., 2017). In many instances, RFIp remains genetically correlated to energy sinks such as milk production ( $r g=-0.16--0.53$ )(Veerkamp et al., 1995; Huttmann et al., 2009; de Haas et al., 2011; Spurlock et al., 2012) and so careful weighting of RFIp is still required in the selection index and makes defining correlations with other traits challenging.

A method closer to the selection indices used in practice is genetic RFI (RFIg) (Kennedy et al., 1993; Lu et al., 2015). In this method, DMI rendered genetically independent of component traits, by including DMI and energy sinks such as body weight, growth, body composition and milk production in a multi trait model the estimated genetic (co)variances can be used to derive a restricted selection index (i.e. RFIg). This allows for the partitioning of genetic components of metabolic efficiency and maintenance efficiency. This has led to increased focus on DMI directly as a means to improve feed efficiency, as selection for decreased DMI is a selection index is essentially equivalent to selection for RFIg (Veerkamp et al., 2013). However, it is still of interest to researchers to assess the genetic parameters of RFIg to ascertain the heritability and genetic correlations with other traits of interest. RFIg can be equivalent to RFIp in the special case that the genetic relationships between DMI and energy sink traits are identical to that of the phenotypic relationships (Kennedy et al., 1993). RFlg is found to repeatable within lactation ( $t=0.54$ ) and over lactations $(t=0.21)$, heritable $(0.14-0.41)$ and genetically correlated to RFIp (0.93) (Lu et al., 2015, 2016). A prerequisite of both RFIp and RFIg is that suitably large numbers of animals with records are required to accurately determine the partial efficiencies between DMI and energy sink traits. 


\subsection{Metagenomics of the rumen microbiome}

The microbes inhabiting the rumen, henceforth referred to as the rumen microbiome, have gained considerable research interest in recent years as is evidenced by reviews to which the reader is directed (Denman and McSweeney, 2014; Bickhart and Weimer, 2017; Tapio et al., 2017; Wallace et al., 2017). This is because the rumen microbiota form the 'missing' link between the host and its diet, their being responsible for the degradation of feed into end products like VFAs and microbial protein which is utilised by the host and end products like $\mathrm{CH}_{4}$ released into the environment (Sutton, 1985; Denman and McSweeney, 2014). Initial characterisation of the rumen microbiota was conducted using microscopy and culture based techniques which was further stimulated by the development of a culture medium of sterile rumen fluid (Hungate, 1947). Culture based techniques allow for the classification, functional annotation and genomic sampling of a particular organism. Currently, the Hungate1000 project has collected 410 rumen bacterial and archaeal pure cultures and have sequenced and catalogued the genomes (Seshadri et al., 2018). It is estimated that $10-15 \%$ of rumen bacteria, for example, are culturable (Morgavi et al., 2012; Denman and McSweeney, 2014).

The standard for culture independent microbial ecology and diversity is sequencing of single genes encoding ribosomal subunits, such as the 16S rRNA gene, circumventing the need for laboratory pure culture (Head et al., 1998). Sequencing and alignment of variable portions of highly conserved genes such as the $16 \mathrm{~S}$ and $18 \mathrm{~S}$ rRNA can be clustered, based on sequence identity, into operational taxonomic units (OTUs) which are indicative of species or strains. This is the most cost effective and a high throughput means of genotyping microbial populations (Bickhart and Weimer, 2017). The reference sequences of OTUs are then assigned taxonomy against open online databases generated from name sequences such as those from pure cultures. A limitation on single gene sequence techniques in the rumen is the paucity of cultured and functionally annotated microbiota, with as many as $74 \%$ of OTUs remain unassigned at genus level in some studies (Kong et al., 2010). In addition, full genome sequence studies have found that mesophilic anaerobic bacteria (such as those in the rumen) horizontally exchange genes between different phyla, exchanging as much as 35\% of metabolic genes (Caro-Quintero and Konstantinidis, 2014), which cannot be captured by simply sequencing the ribosomal 
genes. Costlier and thus, lower throughput limiting methods such as metagenomics (full genomic sequencing) or metatranscriptomics (full sequencing of transcribe rRNA) can overcome some of the limitations to single gene sequencing such as redundancies due to horizontal gene transfer (Bickhart and Weimer, 2017; Wallace et al., 2017). With decreasing costs of sequencing, these methods may become the standard for high throughput genotyping of microbial populations.

There are potential sources of error in ribotyping studies, for instance, up to 100 fold differences in microbial abundances have been detected between different DNA extraction methods (Henderson et al., 2013). Differences between $16 \mathrm{~S}$ rRNA abundances have been detected between the fluid, solid and epimural phases or rumen contents in some studies (Kong et al., 2010; Henderson et al., 2013) but not in others (Ji et al., 2017). Subsequent metagenomic approaches quantified the abundance variations at $0.07-0.48 \%$ between sample positions top, middle and bottom of the rumen (Ross et al., 2012). Few differences have been reported between communities sampled using rumen oral-esophageal tubing and rumen fistula (Henderson et al., 2013), whereas significant differences have been detected between oral-oesophageal tubing and non-invasive buccal swabs, although these differences explained variation is minimal $0.26 \%$ (Kittelmann et al., 2015). A careful design of sampling experiments are required to control or mitigate these sources of variation and standardised protocols are needed if genetic investigations are the primary focus.

Crucially, the spatial and temporal changes in the OTUs in an animal can be associated with biological changes in the animal (Morgavi et al., 2012). This has led to some key developments in ruminant microbial ecology: first, that rumen microbial composition changes depending on the sampling site, solid, liquid or epimural phase (Kong et al., 2010). Second, a core microbiome is present across cows across a broad geographical and dietary range (Henderson et al., 2015). Third, that microbial communities are host specific, reverting almost completely back to the original composition after near complete rumen transfaunation (Weimer et al., 2010). Fourth, communities can change in response to host related changes such as age or lactating vs non-lactating (Zhu et al., 2017). Finally, that communities can change in response to changes in feeding and diet (Tajima et al., 2001).

\subsubsection{Associating rumen microbes with the host phenotype}

A fundamental challenge in rumen microbiology is associating differences in rumen microbial composition and differences in phenotypes of the host and linking this with the biological and functional roles of individual microbes (Bickhart and Weimer, 2017). In the case of feed efficiency, early studies have detected 
significant associations between numerous OTUs, species or higher taxonomic levels in dairy cattle (Jami et al., 2014; Jewell et al., 2015; Shabat et al., 2016) and beef cattle (Guan et al., 2008; Hernandez-Sanabria et al., 2010; Myer et al., 2015). In the case of feed efficiency, direct knowledge of specific biochemical pathways in the rumen contributing to differences in host feed efficiency phenotypes are not known. Furthermore, taxonomical classifications and functional annotations for many rumen microbiota are severely limited, thus linking the functional role of specific microbiota with differences in the host phenotype is extremely challenging. In the case of $\mathrm{CH}_{4}$ production, the methanogenic pathways in archaea and some bacteria are well characterized. Initial results suggested that the abundance of archaea would be directly proportional to $\mathrm{CH}_{4}$ production as methanogenesis is the primary pathway for ATP synthesis in most archaea (Wallace et al., 2014). Subsequently, many studies have not detected associations between archaeal abundance and $\mathrm{CH}_{4}$ production, but have detected associations with non-methanogenic bacteria (Zhou et al., 2011; Danielsson et al., 2017). This could partly be due to the discovery of rumen archaea which metabolise methyl containing compounds and alcohol (Leahy et al., 2010; Poulsen et al., 2013), or studies demonstrating the same archaeal and McrA gene abundance, but differential gene expression in high and low emitting sheep (Shi et al., 2014). The mean archaea to bacteria ratio was from sire progeny groups was found to rank the same as $\mathrm{CH}_{4}$ emission in 50 crossbred beef steers resulting from a two breed rotational cross for Limousin and Angus (steers were 2/3 and $1 / 3$ of either breed) in respiration chambers (Roehe et al., 2016). Suggestive of host additive genetic influence on the microbiome and that bacteria and archaea affect host $\mathrm{CH}_{4}$ emission (Roehe et al., 2016). These results indicate that there is some host phenotype $(\mathrm{P})$ by rumen microbes interactions $(\mathrm{M})$.

\subsubsection{Rumen microbes and diet}

Dietary strategies for $\mathrm{CH}_{4}$ mitigation have been an intense area of research and are the subject of frequent review (Hristov et al., 2013; Knapp et al., 2014; Patra, 2016). These include plant, fungal and macro-algae metabolites, nitrates, nitrooxy and halogenated compounds as well as ionophores. Some of these strategies target the rumen microbes directly for example by inhibiting protozoa and associated archaea serve as hydrogen sinks or are toxic to archaea (Patra, 2016). In the case of ionophores reducing methane emissions also resulted in increased feed efficiency in dairy cattle (Duffield et al., 2008). The majority of these strategies have temporary effects and are not cumulative, but this could be overcome by rotating different additives (Klop et al., 2017). The temporary effects of these strategies suggest rapid microbial community adaption to substrate perturbation (Makkar and Becker, 1997; 
Klop et al., 2017). Conversely, 3-nitrooxypropanol is an additive with a narrow spectrum of specificity inhibiting the enzyme methyl co-enzyme-M reductase, the last step in the methanogenic pathway (Duval and Kindermann, 2012). This compound has been shown to persistently reduce $\mathrm{CH}_{4}$ production in daiy cows by $30 \%$ (Hristov et al., 2015a). These results indicate that there is a diet (D) by microbes (M) interaction.

\subsubsection{Rumen microbes and the host}

The near complete reversion of rumen bacteria to pre-switch composition after 95\% rumen contents switch between cows was the first evidence of host specificity (Weimer et al., 2010). Subsequently, Roehe et al., (2016) sequenced the full rumen metagenome of eight crossbred beef steers divergent for $\mathrm{CH}_{4}$ emission and detected associations between microbial-host cross talk genes TSTA3 and Fucl with host feed conversion ratio. Gonzalez-Recio et al. (2018) found significant associations between relative abundance of rumen microbiota and the first two principal coordinates of a genomic relationships matrix in ten Holstein and 8 Brown Swiss cows. A study involving 48 Israeli Holsteins detected potentially heritable rumen bacteria with 22 rumen bacterial OTUs with heritability estimates in excess of 0.7 (Sasson et al., 2017). Although the validity of heritability estimates in such a small number of animals can be called into question, these results do indicate some host (H) by $M$ interactions.

This evidence would suggest that differences between cows in complex phenotypes (i.e. methane emission and feed efficiency) can be explained by host $(H)$ $x$ microbes $(M) x$ diet (D) interactions (Holobiont concept) (Bickhart and Weimer, 2017). What is needed is substantially larger datasets to determine and quantify the relative contribution of host genetics to rumen microbes and their joint contribution to host phenotypes in order to identify phenotypes influenced by the collective host and microbiome as well as new opportunities for phenotype improvement. Under holobiont theory, the collective unit of host and associated microbes are considered to contribute to differences in host phenotypes upon which natural selection and random genetic drift can act (Zilber-Rosenberg and Rosenberg, 2008; Rosenberg and Zilber-Rosenberg, 2011; Bordenstein and Theis, 2015). There is literature to suggest co-evolutionary genomics of binary (host with specific microbe) host-microbes interactions, however evidence from complex microbial communities (like the rumen microbiome) and the host are lacking. (Yeoman et al., 2011; Bordenstein and Theis, 2015). The consequences of ignoring host-microbe interactions when breeding for $\mathrm{CH}_{4}$ emissions or feed efficiency could result in selective breeding against the every successful symbiosis between ruminant and rumen microbes, 
leading to suboptimal or unpredictable responses to selection, conversely heritable microbes have the potential to further improve breeding from complex traits which are under their influence.

\subsection{Research Aims:}

The main objective of this $\mathrm{PhD}$ project is to investigate and contribute to resolving the lacking understanding of genetic variation behind methane emission, feed efficiency and the rumen microbiome in dairy cattle, by applying integrative and multidisciplinary approaches to phenotype recording. To solve this major task, the PhD project was divided into two main research areas:

(i) Development and validation of a high throughput non-invasive method for recording $\mathrm{CH}_{4}$ emissions under commercial conditions (Chapters 23); and

(ii) Investigate the genetic relationships between $\mathrm{CH}_{4}$ emissions and the interrelations with feed efficiency (Chapter4) and the rumen microbiome (Chapter 5).

A total of four papers are presented as chapters in this PhD dissertation (full publication list is available in Curriculum Vitae) and the aim of each study is presented below.

Chapter 2 'Interchangeability between methane measurements in dairy cows assessed by comparing precision and agreement of two non-invasive infrared methods' The aim was to develop and validate a fast and efficient method for detecting and correcting fixed and variable shifts in times series. To compare two sniffer instruments for $\mathrm{CH}_{4}$ and $\mathrm{CO}_{2}$ breath concentrations in order to identify and quantify sources of disagreement and thereafter standardised instruments for joint recording.

[Published]

Chapter 3 'Rapid Communication: Ranking cows' methane emissions under commercial conditions with sniffers versus respiration chambers' The aim was to assess the consistency in ranking of dairy cows for $\mathrm{CH}_{4}$ emission phenotypes obtained using sniffers and respiration chambers.

[Manuscript draft]

Chapter 4 'Can greenhouse gases in breath be used to genetically improve feed efficiency of dairy cows?' The aim was to estimate genetic parameters for feed intake 
related traits and greenhouse gas traits in primiparous Holsteins in Denmark and The Netherlands. Secondly, assess the use of breath concentration GHG traits as largescale indicator traits for improving the accuracy of breeding values for DMI and genetic residual feed intake.

[Manuscript draft]

Chapter 5 'Host genetics and the rumen microbiome jointly associate with methane emissions in dairy cows' The aim was to detect and quantify associations between rumen microbes and $\mathrm{CH}_{4}$ production. To assess the heritability of rumen bacterial and archaeal relative abundance

[Published]

\section{References}

Arbre, M., Y. Rochette, J. Guyader, C. Lascoux, L.M. Gómez, M. Eugène, D.P. Morgavi, G. Renand, M. Doreau, and C. Martin. 2016. Repeatability of enteric methane determinations from cattle using either the SF6 tracer technique or the GreenFeed system. Anim. Prod. Sci. 56:238-243. doi:10.1071/AN15512.

Van Arendonk, J. a M., G.J. Nieuwhof, H. Vos, and S. Korver. 1991. Genetic aspects of feed intake and efficiency in lactating dairy heifers. Livest. Prod. Sci. 29:263-275. doi:10.1016/0301-6226(91)90103-w.

Arthur, P.F., I.M. Barchia, C. Weber, T. Bird-Gardiner, K.A. Donoghue, R.M. Herd, and R.S. Hegarty. 2017. Optimizing test procedures for estimating daily methane and carbon dioxide emissions in cattle using Short-Term breath measures. J. Anim. Sci. 95:645-656. doi:10.2527/jas2016.0700.

Bach, A., C. Iglesias, and I. Busto. 2004. Technical Note: A Computerized System for Monitoring Feeding Behavior and Individual Feed Intake of Dairy Cattle. J. Dairy Sci. 87:4207-4209. doi:10.3168/jds.S0022-0302(04)73565-1.

Barnhart, H.X., M.J. Haber, and L.I. Lin. 2007. An overview on assessing agreement with continuous measurements.. J. Biopharm. Stat. 17:529-569. doi:10.1080/10543400701376480.

Bauman, D.E., S.N. McCutcheon, W.D. Steinhour, P.J. Eppard, and S.J. Sechen. 1985. Sources of variation and prospects for improvement of productive efficiency in the dairy cow: a review. J. Anim. Sci. 60:583-592.

Bell, M.J., J. Craigon, N. Saunders, J.R. Goodman, and P.C. Garnsworthy. 2018. Does the diurnal pattern of enteric methane emissions from dairy cows change over time?. Animal 1-6. doi:10.1017/S1751731118000228.

Bell, M.J., S.L. Potterton, J. Craigon, N. Saunders, R.H. Wilcox, M. Hunter, J.R. Goodman, and P.C. Garnsworthy. 2014. Variation in enteric methane emissions among cows on commercial dairy farms. Animal 8:1540-1546. doi:10.1017/S1751731114001530.

Berndt, A., T.M. Boland; , M.H. Deighton, J.I. Gere, C. Grainger, R.S. Hegarty, a. D. 
Iwaasa, J.P. Koolaard, K.R. Lassey, D. Luo, R.J. Martin, C. Martin, P.J. Moate, G. Molano, C. Pinares-Patiño, B.E. Ribaux, N.M. Swainson, G.C. Waghorn, and S.R.O. Williams. 2014. Guidelines for Use of Sulphur Hexafluoride ( SF 6 ) Tracer Technique to Measure Enteric Methane Emissions from Ruminants.

Berry, D.P., M.P. Coffey, J.E. Pryce, Y. de Haas, P. Løvendahl, N. Krattenmacher, J.J. Crowley, Z. Wang, D. Spurlock, K. Weigel, K. Macdonald, and R.F. Veerkamp. 2014. International genetic evaluations for feed intake in dairy cattle through the collation of data from multiple sources.. J. Dairy Sci. 97:1-12. doi:10.3168/jds.2013-7548.

Berry, D.P., and J.E. Pryce. 2014. Feed Efficiency in Growing and Mature Animals. 10th World Congr. Genet. Appl. to Livest. Prod. 0:2009-2011.

Bickhart, D.M., and P.J. Weimer. 2017. Host-rumen microbe interactions may be leveraged to improve the productivity of dairy cows. J. Dairy Sci. 1-10. doi:10.3168/jds.2017-13328.

Biscarini, F. 2016. Bayesian Genomic Analysis of Methane Emissions in Dairy Cattle. Accessed July 16, 2018. http://www.methagene.eu/stsmreports/STSM20_Biscarini.pdf.

Bordenstein, S.R., and K.R. Theis. 2015. Host biology in light of the microbiome: Ten principles of holobionts and hologenomes. PLoS Biol. 13:1-23. doi:10.1371/journal.pbio.1002226.

Bossen, D., and M.R. Weisbjerg. 2009. Allocation of feed based on individual dairy cow live weight changes. Il: Effect on milk production. Livest. Sci. 126:273285. doi:10.1016/j.livsci.2009.07.011.

Breider, I.S., E. Wall, P.C. Garnsworhty, and J.E. Pryce. 2018. Genetic relationships between methane emission and milk yield, live weight and dry matter intake. Page in Proceedings of the World Congress on Genetics Applied to Livestock Production, 11.

Brouwer, E. 1965. Energy Metabolism. Academic Press, New York.

Byskov, M. V, A. Fogh, and P. Løvendahl. 2017. Genetic parameters of rumination time and feed efficiency research and commercial conditions. J. Dairy Sci. 19. doi:10.3168/jds.2016-12511.

Cabezas-Garcia, E.H., S.J. Krizsan, K.J. Shingfield, and P. Huhtanen. 2017. Betweencow variation in digestion and rumen fermentation variables associated with methane production. J. Dairy Sci. 100:4409-4424. doi:10.3168/jds.201612206.

Capper, J.L., R. a. Cady, and D.E. Bauman. 2009. The environmental impact of dairy production: 1944 compared with 2007.. J. Anim. Sci. 87:2160-2167. doi:10.2527/jas.2009-1781.

Caro-Quintero, A., and K.T. Konstantinidis. 2014. Inter-phylum HGT has shaped the metabolism of many mesophilic and anaerobic bacteria. ISME J. 9:958-967. doi:10.1038/ismej.2014.193.

Chapinal, N., D.M. Veira, D.M. Weary, and M.A.G. von Keyserlingk. 2007. Technical Note: Validation of a System for Monitoring Individual Feeding and Drinking 
Behavior and Intake in Group-Housed Cattle. J. Dairy Sci. 90:5732-5736. doi:10.3168/jds.2007-0331.

Chizzotti, M.L., F.S. Machado, E.E.L. Valente, L.G.R. Pereira, M.M. Campos, T.R. Tomich, S.G. Coelho, and M.N. Ribas. 2015. Technical note: Validation of a system for monitoring individual feeding behavior and individual feed intake in dairy cattle. J. Dairy Sci. 98:3438-3442. doi:10.3168/jds.2014-8925.

Connor, E.E., J.L. Hutchison, H.D. Norman, K.M. Olson, C.P. Van Tassell, J.M. Leith, and R.L.B. Vi. 2013. Use of residual feed intake in Holsteins during early lactation shows potential to improve feed efficiency through genetic selection. J. Anim. Sci. 91:3978-3988. doi:10.2527/jas2012-5977.

Connor, E.E., J.L. Hutchison, K.M. Olson, and H.D. Norman. 2012. TRIENNIAL LACTATION SYMPOSIUM: Opportunities for improving milk production effi ciency in dairy cattle. J. Anim. Sci. 90:1687-1694. doi:10.2527/jas2011-4528.

Crompton, L.A., C.K. Reynolds, J. France, A. Science, and U. Kingdom. 2010. Fluctuations in methane emission in response to feeding pattern in lactating dairy cows. D. Sauvant, J. Van Milgen, P. Faverdin, and N. Friggens, ed.

Danielsson, R., J. Dicksved, L. Sun, H. Gonda, B. Müller, A. Schnürer, and J. Bertilsson. 2017. Methane Production in Dairy Cows Correlates with Rumen Methanogenic and Bacterial Community Structure. Front. Microbiol. 8:1-15. doi:10.3389/fmicb.2017.00226.

Deighton, M.H., S.R.O. Williams, M.C. Hannah, R.J. Eckard, T.M. Boland, W.J. Wales, and P.J. Moate. 2014. A modified sulphur hexafluoride tracer technique enables accurate determination of enteric methane emissions from ruminants. Anim. Feed Sci. Technol. 197:47-63. doi:10.1016/j.anifeedsci.2014.08.003.

Denman, S.E., and C.S. McSweeney. 2014. The Early Impact of Genomics and Metagenomics on Ruminal Microbiology.. Annu. Rev. Anim. Biosci. 1-19. doi:10.1146/annurev-animal-022114-110705.

DeVries, T.J., M.A.G. von Keyserlingk, D.M. Weary, and K.A. Beauchemin. 2003. Technical Note: Validation of a System for Monitoring Feeding Behavior of Dairy Cows. J. Dairy Sci. 86:3571-3574. doi:10.3168/jds.S00220302(03)73962-9.

Donoghue, K.A., T. Bird-Gardiner, P.F. Arthur, R.M. Herd, and R.F. Hegarty. $2016 a$. Genetic and phenotypic variance and covariance components for methane emission and postweaning traits in Angus cattle. J. Anim. Sci. 94:1438-1445. doi:10.2527/jas2015-0065.

Donoghue, K.A., T. Bird-Gardiner, P.F. Arthur, R.M. Herd, and R.S. Hegarty. 2016b. Repeatability of methane emission measurements in Australian beef cattle. Anim. Prod. Sci. 56:213-217. doi:10.1071/AN15573.

Duffield, T.F., A.R. Rabiee, and I.J. Lean. 2008. A Meta-Analysis of the Impact of Monensin in Lactating Dairy Cattle. Part 2. Production Effects. J. Dairy Sci. 91:1347-1360. doi:10.3168/jds.2007-0608.

Dunlap, H.F., J.S. Bradley, and T.F. Moore. 1960. Marine seep detection-a 
exploration. Geophysics XXV:275-282.

Duval, S., and M. Kindermann. 2012. Use of nitrooxy organic molecules in feed for reducing enteric methane emissions in ruminants, and/or to improve ruminant performance. US Pat. No. WO 84629 (2012): A1.

van Engelen, S., H. Bovenhuis, P.P.J. van der Tol, and M.H.P.W. Visker. 2018. Genetic background of methane emission by Dutch Holstein Friesian cows measured with infrared sensors in automatic milking systems. J. Dairy Sci. 19. doi:10.3168/jds.2017-13441.

Van Es, A.J.H. 1978. Feed evaluation for ruminants. 1. Systems in use from May 1977 onwards in Netherlands. Livest. Prod. Sci. 5:331-345.

Gardiner, T.D., M.D. Coleman, F. Innocenti, J. Tompkins, A. Connor, P.C. Garnsworthy, J.M. Moorby, C.K. Reynolds, A. Waterhouse, and D. Wills. 2015. Determination of the absolute accuracy of UK chamber facilities used in measuring methane emissions from livestock. Meas. J. Int. Meas. Confed. 66:272-279. doi:10.1016/j.measurement.2015.02.029.

Garnsworthy, P.C., J. Craigon, J.H. Hernandez-Medrano, and N. Saunders. 2012. Onfarm methane measurements during milking correlate with total methane production by individual dairy cows. J. Dairy Sci. 95:3166-80. doi:10.3168/jds.2011-4605.

Gerber, P.., H. Steinfeld, B. Henderson, A. Mottet, C. Opio, J. Dijkman, A. Falcucci, and G. Tempio. 2013. Tackling Climate Change through Livestock - A Global Assessment of Emissions and Mitigation Opportunities.

Gerrits, W.J.J., Labussiere, E., Reynolds, C.K., Metges, C.C., Kuhla, B., Lund, P., Weisbjerg, M.R. and Dijkstra, J., 2018. Letter to the Editor: Recovery test results as a prerequisite for publication of gaseous exchange measurements. Journal of dairy science, 101(6), pp.4703-4704.

Global Research Alliance. 2012. Technical Manual on Respiration Chamber Designs. G.C. Waghorn and C.S. Pinares-Patiño, ed. Ministry of Agriculture and Fisheries, New Zealand.

Gonzalez-Recio, O., I. Zubiria, A. Hurtado, and R. Atxaerandio. 2018. Short communication: Signs of host genetic regulation in the microbiome composition in 2 dairy breeds : Holstein and Brown Swiss. J. Dairy Sci. 101:2285-2292. doi:10.3168/jds.2017-13179.

Grainger, C., T. Clarke, S.M. McGinn, M.J. Auldist, K. a Beauchemin, M.C. Hannah, G.C. Waghorn, H. Clark, and R.J. Eckard. 2007. Methane emissions from dairy cows measured using the sulfur hexafluoride (SF6) tracer and chamber techniques. J. Dairy Sci. 90:2755-2766. doi:10.3168/jds.2006-697.

Guan, L.L., J.D. Nkrumah, J.A. Basarab, and S.S. Moore. 2008. Linkage of microbial ecology to phenotype: Correlation of rumen microbial ecology to cattle's feed efficiency. FEMS Microbiol. Lett. 288:85-91. doi:10.1111/j.15746968.2008.01343.x.

Gunsett, F.C. 1984. Linear index selection to improve traits defined as ratios. J. Anim. Sci. 59:1185-1193. 
de Haas, Y., J.J.J. Windig, M.P.L.P.L. Calus, J. Dijkstra, M. de Haan, a. Bannink, R.F.F. Veerkamp, M. De Haan, a. Bannink, and R.F.F. Veerkamp. 2011. Genetic parameters for predicted methane production and potential for reducing enteric emissions through genomic selection.. J. Dairy Sci. 94:6122-34. doi:10.3168/jds.2011-4439.

Hammond, K.J., L.A. Crompton, A. Bannink, J. Dijkstra, D.R. Yáñez-Ruiz, P. O’Kiely, E. Kebreab, M.A. Eugenè, Z. Yu, K.J. Shingfield, A. Schwarm, A.N. Hristov, and C.K. Reynolds. 2016a. Review of current in vivo measurement techniques for quantifying enteric methane emission from ruminants. Anim. Feed Sci. Technol. 219:13-30. doi:10.1016/j.anifeedsci.2016.05.018.

Hammond, K.J., D.J. Humphries, L. a. Crompton, C. Green, and C.K. Reynolds. 2015. Methane emissions from cattle: Estimates from short-term measurements using a GreenFeed system compared with measurements obtained using respiration chambers or sulphur hexafluoride tracer. Anim. Feed Sci. Technol. 203:41-52. doi:10.1016/j.anifeedsci.2015.02.008.

Hammond, K.J., G.C. Waghorn, and R.S. Hegarty. 2016b. The GreenFeed system for measurement of enteric methane emission from cattle. Anim. Prod. Sci. 56:181-189. doi:10.1071/AN15631.

Hayes, B.J., K.A. Donoghue, C.M. Reich, B.A. Mason, T. Bird-Gardiner, R.M. Herd, and P.F. Arthur. 2016. Genomic heritabilities and genomic estimated breeding values for methane traits in Angus cattle. J. Anim. Sci. 94:902-908. doi:10.2527/jas2015-0078.

Head, I.M., J.R. Saunders, and R.W. Pickup. 1998. Microbial Evolution, Diversity, and Ecology: A Decade of Ribosomal RNA Analysis of Uncultivated Microorganisms. Microb. Ecol. 35:1-21.

Hegarty, R.S. 2013. Applicability of short-term emission measurements for on-farm quantification of enteric methane.. Animal 7 Suppl 2:401-8. doi:10.1017/S1751731113000839.

Hellwing, A.L.F., P. Lund, J. Madsen, and M.R. Weisbjerg. 2013. Comparison of enteric methane production predicted from the $\mathrm{CH} 4 / \mathrm{CO} 2$ ratio and measured in respiration chambers. Adv. Anim. Biosci. 4:6077-6085.

Hellwing, A.L.F., P. Lund, M.R. Weisbjerg, M. Brask, and T. Hvelplund. 2012. Technical note: test of a low-cost and animal-friendly system for measuring methane emissions from dairy cows. J. Dairy Sci. 95:6077-85. doi:10.3168/jds.2012-5505.

Hemme, T., M.M. Uddin, and O.A. Ndambi. 2014. Benchmarking Cost of Milk Production in 46 Countries. J. Rev. Glob. Econ. 254-270.

Henderson, G., F. Cox, S. Ganesh, A. Jonker, W. Young, and P.H. Janssen. 2015. Rumen microbial community composition varies with diet and host, but a core microbiome is found across a wide geographical range.. Sci. Rep. 5:14567. doi:10.1038/srep14567.

Henderson, G., F. Cox, S. Kittelmann, V.H. Miri, M. Zethof, S.J. Noel, G.C. Waghorn, and P.H. Janssen. 2013. Effect of DNA Extraction Methods and Sampling 
Techniques on the Apparent Structure of Cow and Sheep Rumen Microbial Communities 8:1-14. doi:10.1371/journal.pone.0074787.

Hernandez-Sanabria, E., L.L. Guan, L.A. Goonewardene, M. Li, D.F. Meiju, P.

Stothard, S.S. Moore, and M.C. Leon-Quintero. 2010. Correlation of particular bacterial pcr-denaturing gradient gel electrophoresis patterns with bovine ruminal fermentation parameters and feed efficiency traits. Appl. Environ. Microbiol. 76:6338-6350. doi:10.1128/AEM.01052-10.

Hill, J., C. McSweeney, A.-D.G. Wright, G. Bishop-Hurley, and K. Kalantar-zadeh. 2016. Measuring methane production from ruminants. Trends Biotechnol. 34:26-35. doi:10.1016/j.tibtech.2015.10.004.

Holmes, C.D., M.J. Prather, O.A. S $\varnothing$ vde, and G. Myhre. 2013. Future methane, hydroxyl, and their uncertainties: Key climate and emission parameters for future predictions. Atmos. Chem. Phys. 13:285-302. doi:10.5194/acp-13-2852013.

Hristov, A.., J. Oh, F. Giallongo, T.. Frederick, M.. Harper, H.. Weeks, A.. Branco, P.. Moate, M.. Deighton, S.R.. Williams, M. Kindermann, and S. Duval. 2015a. An inhibitor persistently decreased enteric methane emission from dairy cows with no negative effect on milk production. Proc. Natl. Acad. Sci. 112:1066310668. doi:10.1073/pnas.1504124112.

Hristov, A.N., E. Kebreab, M. Niu, J. Oh, A. Bannink, A.R. Bayat, T.M. Boland, and A.F. Brito. 2018. Symposium review : Uncertainties in enteric methane inventories, measurement techniques, and prediction models $16655-6674$. doi:10.3168/jds.2017-13536.

Hristov, A.N., J. Oh, J.L. Firkins, J. Dijkstra, E. Kebreab, G. Waghorn, H.P.S. Makkar, A.T. Adesogan, W. Yang, C. Lee, P.J. Gerber, B. Henderson, and J.M. Tricarico. 2013. SPECIAL TOPICS-Mitigation of methane and nitrous oxide emissions from animal operations: I. A review of enteric methane mitigation options. J. Anim. Sci. 91:5045-5069. doi:10.2527/jas2013-6583.

Hristov, A.N., J. Oh, F. Giallongo, T. Frederick, H. Weeks, P.R. Zimmerman, M.T. Harper, R.A. Hristova, R.S. Zimmerman, and A.F. Branco. 2015b. The Use of an Automated System (GreenFeed) to Monitor Enteric Methane and Carbon Dioxide Emissions from Ruminant Animals. J. Vis. Exp. 52904. doi:10.3791/52904.

Huhtanen, P., E.H. Cabezas-Garcia, S. Utsumi, and S. Zimmerman. 2015. Comparison of methods to determine methane emissions from dairy cows in farm conditions. J. Dairy Sci. 98:3394-3409. doi:10.3168/jds.2014-9118.

Hungate, R.E. 1947. Studies on cellulose fermentation: III. The culture and isolation for cellulose-decomposing Bacteria from the rumen of cattle 1. J. Bacteriol. 53:631-645.

Huttmann, H., E. Stamer, W. Junge, G. Thaller, and E. Kalm. 2009. Analysis of feed intake and energy balance of high-yielding first lactating Holstein cows with fixed and random regression models. Animal 3:181-188. doi:10.1017/S175173110800325X. 
IPCC. 2014. Climate Change 2014: Synthesis Report. Contribution of Working Groups I, II and III to the Fifth Assessment Report of the Intergovernmental Panel on Climate Change.

Jami, E., B.A. White, and I. Mizrahi. 2014. Potential Role of the Bovine Rumen Microbiome in Modulating Milk Composition and Feed Efficiency 9. doi:10.1371/journal.pone.0085423.

Janssen, P.H., and M. Kirs. 2008. Structure of the archaeal community of the rumen. Appl. Environ. Microbiol. 74:3619-3625. doi:10.1128/AEM.02812-07.

Jensen, J., I. Mao, B. Andersen, and P. Madsen. 1992. Phenotypic and genetic relationships between residual energy intake and growth, feed intake, and carcass traits of young bulls. J. Anim. Sci. 70:386-395.

Jewell, K.A., C.A. McCormick, C.L. Odt, P.J. Weimer, and G. Suen. 2015. Ruminal Bacterial Community Composition in Dairy Cows Is Dynamic over the Course of Two Lactations and Correlates with Feed Efficiency.. Appl. Environ. Microbiol. 81:4697-710. doi:10.1128/AEM.00720-15.

Ji, S., H. Zhang, H. Yan, A. Azarfar, H. Shi, G. Alugongo, S. Li, Z. Cao, and Y. Wang. 2017. Comparison of rumen bacteria distribution in original rumen digesta, rumen liquid and solid fractions in lactating Holstein cows. J. Anim. Sci. Biotechnol. 8:1-7. doi:10.1186/s40104-017-0142-z.

Johnson, K., M. Huyler, H. Westberg, B. Lamb, and P. Zimmerman. 1994. Measurement of methane emissions from ruminant livestock using a sulfur hexafluoride tracer technique. Environ. Sci. Technol. 28:359-362. doi:10.1021/es00051a025.

Johnson, K.A., and D.E. Johnson. 1995. Methane emissions from cattle Methane Emissions from Cattle. Anim. Sci. J. 73:2483-2492.

Jonker, A., G. Molano, C. Antwi, and G.C. Waghorn. 2016. Enteric methane and carbon dioxide emissions measured using respiration chambers, the sulfur hexafluoride tracer technique, and a greenfeed head-chamber system from beef heifers fed alfalfa silage at three allowances and four feeding frequencies. J. Anim. Sci. 94:4326-4337. doi:10.2527/jas2016-0646.

Kamke, J., S. Kittelmann, P. Soni, Y. Li, M. Tavendale, S. Ganesh, P.H. Janssen, W. Shi, J. Froula, E.M. Rubin, and G.T. Attwood. 2016. Rumen metagenome and metatranscriptome analyses of low methane yield sheep reveals a Sharpeaenriched microbiome characterised by lactic acid formation and utilisation. Microbiome 4:56. doi:10.1186/s40168-016-0201-2.

Kellner, O. 1909. The Scientific Feeding of Animals. Mcmillan company, New York. Kennedy, B.W., J.H.J. Van Der Werf, and T.H.E. Meuwissent. 1993. Genetic and Statistical Properties of Residual Feed Intake' 3239-3250.

Kittelmann, S., M.R. Kirk, A. Jonker, A. McCulloch, and P.H. Janssen. 2015. Buccal swabbing as a noninvasive method to determine bacterial, archaeal, and eukaryotic microbial community structures in the rumen. Appl. Environ. Microbiol. 81:7470-7483. doi:10.1128/AEM.02385-15.

Klop, G., J. Dijkstra, K. Dieho, W.H. Hendriks, and A. Bannink. 2017. Enteric methane 
production in lactating dairy cows with continuous feeding of essential oils or rotational feeding of essential oils and lauric acid. J. Dairy Sci. 1-13. doi:10.3168/jds.2016-12033.

Knapp, J.R., G.L. Laur, P. a Vadas, W.P. Weiss, and J.M. Tricarico. 2014. Invited review: Enteric methane in dairy cattle production: quantifying the opportunities and impact of reducing emissions.. J. Dairy Sci. 97:3231-61. doi:10.3168/jds.2013-7234.

Koenen, E.P.C., and R.F. Veerkamp. 1998. Genetic covariance functions for live weight, condition score, and dry-matter intake measured at different lactation stages of Holstein Friesian heifers. Livest. Prod. Sci. 57:67-77. doi:10.1016/S0301-6226(98)00159-6.

Kong, Y., R. Teather, and R. Forster. 2010. Composition, spatial distribution, and diversity of the bacterial communities in the rumen of cows fed different forages. FEMS Microbiol. Ecol. 74:612-622. doi:10.1111/j.15746941.2010.00977.x.

Korver, S. 1988. Genetic aspects of feed intake and feed efficiency in dairy cattle: A review. Livest. Prod. Sci. 20:1-13. doi:10.1016/0301-6226(88)90049-8.

Krogh, A. 1916. The respiratory exchange of animals and man. University of Copenhagen,.

Lassen, J., and P. Løvendahl. 2016. Heritability estimates for enteric methane emissions from Holstein cattle measured using noninvasive methods. J. Dairy Sci. 99:1959-1967. doi:10.3168/jds.2015-10012.

Lassen, J., P. Løvendahl, and J. Madsen. 2012. Accuracy of noninvasive breath methane measurements using Fourier transform infrared methods on individual cows. J. Dairy Sci. 95:890-8. doi:10.3168/jds.2011-4544.

Lassen, J., N.A. Poulsen, M.K. Larsen, and A.J. Buitenhuis. 2016. Genetic and genomic relationship between methane production measured in breath and fatty acid content in milk samples from Danish Holsteins. Anim. Prod. Sci. 56:298-303. doi:10.1071/AN15489.

Leahy, S.C., W.J. Kelly, E. Altermann, R.S. Ronimus, C.J. Yeoman, D.M. Pacheco, D. Li, Z. Kong, S. McTavish, C. Sang, S.C. Lambie, P.H. Janssen, D. Dey, and G.T. Attwood. 2010. The genome sequence of the rumen methanogen Methanobrevibacter ruminantium reveals new possibilities for controlling ruminant methane emissions.. PLoS One 5:e8926. doi:10.1371/journal.pone.0008926.

Li, B., B. Berglund, W.F. Fikse, J. Lassen, M.H. Lidauer, P. Mäntysaari, P. Løvendahl, D.J. Garrick, J.C.M. Dekkers, C.R. Baumrucker, M.J. VandeHaar, and Y. De Haas. 2017. Neglect of lactation stage leads to naive assessment of residual feed intake in dairy cattle.. J. Dairy Sci. 92:2270-2275. doi:10.3168/jds.201712775.

Lu, Y., M.J. Vandehaar, D.M. Spurlock, K.A. Weigel, L.E. Armentano, C.R. Staples, E.E. Connor, Z. Wang, N.M. Bello, and R.J. Tempelman. 2015. An alternative approach to modeling genetic merit of feed efficiency in dairy cattle. J. Dairy 
Sci. 98:6535-6551. doi:10.3168/jds.2015-9414.

Lu, Y., M.J. Vandehaar, D.M. Spurlock, K.A. Weigel, L.E. Armentano, C.R. Staples, E.E. Connor, Z. Wang, M. Coffey, R.F. Veerkamp, Y. de Haas, and R.J. Tempelman. 2016. Modeling genetic and nongenetic variation of feed efficiency and its partial relationships between component traits as a function of management and environmental factors. J. Dairy Sci. 0:26002605. doi:10.3168/jds.2016-11491.

Madsen, J., B.S. Bjerg, T. Hvelplund, M.R. Weisbjerg, and P. Lund. 2010. Methane and carbon dioxide ratio in excreted air for quantification of the methane production from ruminants. Livest. Sci. 129:223-227. doi:10.1016/j.livsci.2010.01.001.

Makkar, H.P.S., and K. Becker. 1997. Degradation of quillaja saponins by mixed culture of rumen microbes. Lett. Appl. Microbiol. 25:243-245. doi:10.1046/j.1472-765X.1997.00207.x.

Manzanilla Pech, C.I. V, R.F. Veerkamp, M.P.L. Calus, R. Zom, a van Knegsel, J.E. Pryce, and Y. De Haas. 2014. Genetic parameters across lactation for feed intake, fat- and protein-corrected milk, and liveweight in first-parity Holstein cattle.. J. Dairy Sci. 97:5851-5862. doi:10.3168/jds.2014-8165.

Martin, C., D.P. Morgavi, and M. Doreau. 2010. Methane mitigation in ruminants: from microbe to the farm scale. Animal 4:351-365. doi:10.1017/S1751731109990620.

Mason, I.L., A. Robertson, and B. Gjeltstad. 1957. The genetic connexion between body size, milk production and efficiency in dairy cattle. J. Dairy Res. 24:135143.

McAllister, T.A., and C.J. Newbold. 2008. Redirecting rumen fermentation to reduce methanogenesis. Aust. J. Exp. Agric. 48:7-13. doi:10.1071/EA07218.

McLean, A., and G. Tobin. 1987. Animal and Human Calorimetry. Cambridge University Press, Cambridge.

Møller, H.B., V. Moset, M. Brask, M.R. Weisbjerg, and P. Lund. 2014. Feces composition and manure derived methane yield from dairy cows: Influence of diet with focus on fat supplement and roughage type. Atmos. Environ. 94:36-43. doi:10.1016/j.atmosenv.2014.05.009.

Morgavi, D.P., W.J. Kelly, P.H. Janssen, and G.T. Attwood. 2012. Rumen microbial (meta)genomics and its application to ruminant production. Animal 1-18. doi:10.1017/S1751731112000419.

Moss, A.R., J.-P. Jouany, and J. Newbold. 2000. Methane production by ruminants : its contribution to global warming (Review article). Ann. Zootech. 49:231253. doi:10.1051/animres:2000119.

Muñoz, C., T. Yan, D.A. Wills, S. Murray, and A.W. Gordon. 2012. Comparison of the sulfur hexafluoride tracer and respiration chamber techniques for estimating methane emissions and correction for rectum methane output from dairy cows. J. Dairy Sci. 95:3139-48. doi:10.3168/jds.2011-4298.

Murray, B.Y.R.M., A.M. Bryant, and R.A. Leng. 1976. Rates of production of 
methane in the rumen and large intestine of sheep. Br. J. Nutr. 36:1-14.

Myer, P.R., T.P.L. Smith, J.E. Wells, L.A. Kuehn, and H.C. Freetly. 2015. Rumen microbiome from steers differing in feed efficiency. PLoS One 10:1-17. doi:10.1371/journal.pone.0129174.

Negussie, E., J. Lehtinen, P. Mäntysaari, A.R. Bayat, A.-E. Liinamo, E.A. Mäntysaari, and M.H. Lidauer. 2016. Non-invasive individual methane measurement in dairy cows. Animal 4:1-10. doi:10.1017/S1751731116002718.

Nielsen, H.M., N.C. Friggens, P. Løvendahl, J. Jensen, and K.L. Ingvartsen. 2003. Influence of breed, parity, and stage of lactation on lactational performance and relationship between body fatness and live weight. Livest. Prod. Sci. 79:119-133. doi:10.1016/S0301-6226(02)00146-X.

O'Mara, F.P. 2012. The role of grasslands in food security and climate change. Ann. Bot. 110:1263-1270. doi:10.1093/aob/mcs209.

Patra, A.K. 2012. Enteric methane mitigation technologies for ruminant livestock: A synthesis of current research and future directions. Environ. Monit. Assess. 184:1929-1952. doi:10.1007/s10661-011-2090-y.

Patra, A.K. 2016. Recent advances in measurement and dietary mitigation of enteric methane emissions in ruminants. Front. Vet. Sci. 3:1-17. doi:10.3389/fvets.2016.00039.

Pinares-Patiño, C.S., S.M. Hickey, E. a Young, K.G. Dodds, S. MacLean, G. Molano, E. Sandoval, H. Kjestrup, R. Harland, C. Hunt, N.K. Pickering, and J.C. McEwan. 2013. Heritability estimates of methane emissions from sheep.. Animal 7 Suppl 2:316-321. doi:10.1017/S1751731113000864.

Poulsen, M., C. Schwab, B.B. Jensen, R.M. Engberg, A. Spang, N. Canibe, O. Højberg, G. Milinovich, L. Fragner, C. Schleper, W. Weckwerth, P. Lund, A. Schramm, and T. Urich. 2013. Methylotrophic methanogenic Thermoplasmata implicated in reduced methane emissions from bovine rumen.. Nat. Commun. 4:1428. doi:10.1038/ncomms2432.

Pryce, J.E., O. Gonzalez-Recio, G. Nieuwhof, W.J. Wales, M.P. Coffey, B.J. Hayes, and M.E. Goddard. 2015. Hot topic: Definition and implementation of a breeding value for feed efficiency in dairy cows.. J. Dairy Sci. 98:7340-50. doi:10.3168/jds.2015-9621.

Pryce, J.E., W.J. Wales, Y. de Haas, R.F. Veerkamp, and B.J. Hayes. 2014. Genomic selection for feed efficiency in dairy cattle.. Animal 8:1-10. doi:10.1017/S1751731113001687.

Pszczola, M., K. Rzewuska, S. Mucha, and T. Strabel. 2017. Heritability of methane emissions from dairy cows over a lactation measured on commercial farms.. J. Anim. Sci.. doi:10.2527/jas2017.1842.

Ricci, P., J. a. Rooke, I. Nevison, and a. Waterhouse. 2013. Methane emissions from beef and dairy cattle: Quantifying the effect of physiological stage and diet characteristics. J. Anim. Sci. 91:5379-5389. doi:10.2527/jas.2013-6544.

Rischewski, J., A. Bielak, G. Nürnberg, M. Derno, and B. Kuhla. 2017. Rapid communication: Ranking dairy cows for methane emissions measured using 
respiration chamber or greenFeed techniques during early, peak, and late lactation. J. Anim. Sci. 95:3154-3159. doi:10.2527/jas2017.1530.

Roehe, R., R. Dewhurst, C.-A. Duthie, J. Rooke, N. McKain, D. Ross, J. Hyslop, A. Waterhouse, M. Watson, and J. Wallace. 2016. Bovine Host Genetic Variation Influences Rumen Microbial Methane Production with Best Selection Criterion for Low Methane Emitting and Efficiently Feed Converting Hosts based on Metagenomic Gene Abundance. PLoS Genet. 12:1-28. doi:10.1371/journal.pgen.1005846.

Rosenberg, E., and I. Zilber-Rosenberg. 2011. Symbiosis and development: The hologenome concept. Birth Defects Res. Part C - Embryo Today Rev. 93:5666. doi:10.1002/bdrc.20196.

Ross, E.M., P.J. Moate, C.R. Bath, S.E. Davidson, T.I. Sawbridge, K.M. Guthridge, B.G. Cocks, and B.J. Hayes. 2012. High throughput whole rumen metagenome profiling using untargeted massively parallel sequencing. BMC Genet. 13:53. doi:10.1186/1471-2156-13-53.

Sasson, G., S.K. Ben-shabat, and E. Seroussi. 2017. Heritable Bovine Rumen Bacteria Are Phylogenetically Related and Correlated with the Cow's Capacity To Harvest. MBio 8:1-12.

Seshadri, R., S.C. Leahy, G.T. Attwood, K.H. Teh, S.C. Lambie, A.L. Cookson, E.A. Eloe-fadrosh, G.A. Pavlopoulos, M. Hadjithomas, N.J. Varghese, D. Paezespino, R. Perry, G. Henderson, C.J. Creevey, N. Terrapon, P. Lapebie, E. Drula, V. Lombard, E. Rubin, N.C. Kyrpides, B. Henrissat, T. Woyke, N.N. Ivanova, and W.J. Kelly. 2018. Cultivation and sequencing of rumen microbiome members from the Hungate1000 Collection. Nat. Biotechnol. 36:359-367. doi:10.1038/nbt.4110.

Shabat, S.K. Ben, G. Sasson, A. Doron-Faigenboim, T. Durman, S. Yaacoby, M.E. Berg Miller, B. a White, N. Shterzer, and I. Mizrahi. 2016. Specific microbiomedependent mechanisms underlie the energy harvest efficiency of ruminants. ISME J. 10:1-15. doi:10.1038/ismej.2016.62.

Shi, W., C.D. Moon, S.C. Leahy, D. Kang, J. Froula, S. Kittelmann, C. Fan, S. Deutsch, D. Gagic, H. Seedorf, W.J. Kelly, R. Atua, C. Sang, P. Soni, D. Li, C.S. PinaresPatiño, J.C. McEwan, P.H. Janssen, F. Chen, A. Visel, Z. Wang, G.T. Attwood, and E.M. Rubin. 2014. Methane yield phenotypes linked to differential gene expression in the sheep rumen microbiome. Genome Res. 24:1517-1525. doi:10.1101/gr.168245.113.

Shirali, M., P.F. Varley, and J. Jensen. 2018. Bayesian estimation of direct and correlated responses to selection on linear or ratio expressions of feed efficiency in pigs. Genet. Sel. Evol. 1-12. doi:10.1186/s12711-018-0403-0.

Sondergaard, E., M.K. Sorensen, I.L. Mao, and J. Jensen. 2002. Genetic parameters of production, feed intake, body weight, body composition, and udder health in lactating dairy cows. Livest. Prod. Sci. 77:23-34.

Spurlock, D.M., J.C.M. Dekkers, R. Fernando, D. a Koltes, and a Wolc. 2012. Genetic parameters for energy balance, feed efficiency, and related traits in Holstein 
cattle.. J. Dairy Sci. 95:5393-402. doi:10.3168/jds.2012-5407.

Storm, I.M.L.D., A.L.F. Hellwing, N.I. Nielsen, and J. Madsen. 2012. Methods for measuring and estimating methane emission from ruminants. Animals 2:160183. doi:10.3390/ani2020160.

Sutherland, T.M. 1965. The correlation between feed efficiency and rate of gain, a ratio and its denominator. Biometrics 21:739-749.

Sutton, J.D. 1985. Digestion and absorption of energy substrates in the lactating cow. J. Dairy Sci. 68:3376-3393.

Tajima, K., T. Nagamine, H. Matsui, and M. Nakamura. 2001. Phylogenetic analysis of archaeal 16S rRNA libraries from the rumen suggests the existence of a novel group of archaea not associated with known methanogens. doi:10.1016/S0378-1097(01)00201-4.

Tapio, I., T.J. Snelling, F. Strozzi, and R.J. Wallace. 2017. The ruminal microbiome associated with methane emissions from ruminant livestock. J. Anim. Sci. Biotechnol. 8:2-11. doi:10.1186/s40104-017-0141-0.

Tempelman, R.J., D.M. Spurlock, M. Coffey, R.F. Veerkamp, L.E. Armentano, K.A. Weigel, Y. de Haas, C.R. Staples, E.E. Connor, Y. Lu, and M.J. VandeHaar. 2015. Heterogeneity in genetic and nongenetic variation and energy sink relationships for residual feed intake across research stations and countries.. J. Dairy Sci. 98:2013-26. doi:10.3168/jds.2014.8510.

Tolkamp, B.J., and I. Kyriazakis. 1997. Measuring diet selection in dairy cows: Effect of training on choice of dietary protein level. Anim. Sci. 64:197-207. doi:10.1017/S1357729800015745.

Vandehaar, M.J., L.E. Armentano, K. Weigel, D.M. Spurlock, R.J. Tempelman, and R. Veerkamp. 2016. Harnessing the genetics of the modern dairy cow to continue improvements in feed efficiency $14941-4954$. doi:10.3168/jds.2015-10352.

Veerkamp, R.F., and G.C. Emmans. 1995. Sources of genetic variation in energetic efficiency of dairy cows. Livest. Prod. Sci. 44:87-97. doi:10.1016/03016226(95)00065-0.

Veerkamp, R.F., G.C. Emmans, a. R. Cromie, and G. Simm. 1995. Variance components for residual feed intake in dairy cows. Livest. Prod. Sci. 41:111120. doi:10.1016/0301-6226(94)00056-D.

Veerkamp, R.F., J.E. Pryce, D.M. Spurlock, D.P. Berry, M.P. Coffey, P. Løvendahl, R. van der Linde, J. Bryant, F. Miglior, Z. Wang, M. Winters, N. Krattenmacher, N. Charfeddine, J. Pedersen, and Y. de Haas. 2013. Selection on Feed Intake or Feed Efficiency: A Position Paper from gDMI Breeding Goal Discussions. Interbull Bull.

Velazco, J.I., R.M. Herd, D.J. Cottle, and R.S. Hegarty. 2017. Daily methane emissions and emission intensity of grazing beef cattle genetically divergent for residual feed intake. Anim. Prod. Sci. 57:627-635. doi:10.1071/AN15111.

Velazco, J.I., D.G. Mayer, S. Zimmerman, and R.S. Hegarty. 2015. Use of short-term breath measures to estimate daily methane production by cattle. Animal 1-9. 
doi:10.1017/S1751731115001603.

Volden, H. 2011. NorFor - The Nordic Feed Evaluation System. EAAP Publication No. 130. Wageningen Academic Publishers, Wageningen, the Netherlands.

Waghorn, G.C., and R.S. Hegarty. 2011. Lowering ruminant methane emissions through improved feed conversion efficiency. Anim. Feed Sci. Technol. 166167:291-301. doi:10.1016/j.anifeedsci.2011.04.019.

Waghorn, G.C., a Jonker, and K. a Macdonald. 2016. Measuring methane from grazing dairy cows using GreenFeed 252-257. doi:10.1071/AN15491.

Wallace, R.J., J.A. Rooke, C.A. Duthie, J.J. Hyslop, D.W. Ross, N. McKain, S.M. De Souza, T.J. Snelling, A. Waterhouse, and R. Roehe. 2014. Archaeal abundance in post-mortem ruminal digesta may help predict methane emissions from beef cattle. Sci. Rep. 4:1-8. doi:10.1038/srep05892.

Wallace, R.J., T.J. Snelling, C.A. McCartney, I. Tapio, and F. Strozzi. 2017. Application of meta-omics techniques to understand greenhouse gas emissions originating from ruminal metabolism. Genet. Sel. Evol. 49:9. doi:10.1186/s12711-017-0285-6.

Weimer, P.J., D.M. Stevenson, H.C. Mantovani, and S.L.C. Man. 2010. Host specificity of the ruminal bacterial community in the dairy cow following near-total exchange of ruminal contents.. J. Dairy Sci. 93:5902-5912. doi:10.3168/jds.2010-3500.

Williams, S.R.O., P.J. Moate, M.C. Hannah, B.E. Ribaux, W.J. Wales, and R.J. Eckard. 2011. Background matters with the SF6tracer method for estimating enteric methane emissions from dairy cows: A critical evaluation of the SF6procedure. Anim. Feed Sci. Technol. 170:265-276. doi:10.1016/j.anifeedsci.2011.08.013.

Wu, L., P.W.G.G. Koerkamp, and N. Ogink. 2018. Uncertainty assessment of the breath methane concentration method to determine methane production of dairy cows. J. Dairy Sci. 101:1554-1564. doi:10.3168/jds.2017-12710.

Yan, T., C.S. Mayne, F.G. Gordon, M.G. Porter, R.E. Agnew, D.C. Patterson, C.P. Ferris, and D.J. Kilpatrick. 2010. Mitigation of enteric methane emissions through improving efficiency of energy utilization and productivity in lactating dairy cows.. J. Dairy Sci. 93:2630-2638. doi:10.3168/jds.2009-2929.

Yeoman, C.J., N. Chia, S. Yildirim, M.E.B. Miller, A. Kent, R. Stumpf, S.R. Leigh, K.E. Nelson, B.A. White, and B.A. Wilson. 2011. Towards an Evolutionary Model of Animal-Associated Microbiomes 570-594. doi:10.3390/e13030570.

Zetouni, L., M. Henryon, M. Kargo, and J. Lassen. 2017. Direct multitrait selection realizes the highest genetic response for ratio traits. J. Anim. Sci. 95:19211925. doi:10.2527/jas2016.1324.

Zetouni, L., M. Kargo, E. Norberg, and J. Lassen. 2018. Genetic correlations between methane production and fertility, health, and body type traits in Danish Holstein cows. J. Dairy Sci. 101:1-8. doi:10.3168/jds.2017-13402.

Zhou, M., Y.H. Chung, K.A. Beauchemin, L. Holtshausen, M. Oba, T.A. McAllister, and L.L. Guan. 2011. Relationship between rumen methanogens and 
methane production in dairy cows fed diets supplemented with a feed enzyme additive. J. Appl. Microbiol. 111:1148-1158. doi:10.1111/j.13652672.2011.05126.x.

Zhu, Z., S.J. Noel, G.F. Difford, W.A. Al-Soud, A. Brejnrod, S.J. Sørensen, J. Lassen, P. Løvendahl, and O. Højberg. 2017. Community structure of the metabolically active rumen bacterial and archaeal communities of dairy cows over the transition period. PLoS One 12. doi:10.1371/journal.pone.0187858.

Zilber-Rosenberg, I., and E. Rosenberg. 2008. Role of microorganisms in the evolution of animals and plants: The hologenome theory of evolution. FEMS Microbiol. Rev. 32:723-735. doi:10.1111/j.1574-6976.2008.00123.x.

Zimmerman, P. 2011. Method and System for Monitoring and Reducing Ruminant Methane Production. US Pat. No. 7966971B2.

Zom, R.L.G., G. André, and A.M. van Vuuren. 2012. Development of a model for the prediction of feed intake by dairy cows: 1 . Prediction of feed intake. Livest. Sci. 143:43-57. doi:10.1016/j.livsci.2011.08.014. 




\title{
Chapter 2
}

\section{Interchangeability between methane measurements in dairy cows assessed by comparing precision and agreement of two non-invasive infrared methods}

\author{
G.F Difford ${ }^{1,2}$, J. Lassen ${ }^{1}$, P. Løvendahl ${ }^{1}$ \\ ${ }^{1}$ Department of Molecular Biology and Genetics, Faculty of Science \\ and Technology, Aarhus University, PO Box 50, DK-8830 Tjele, Denmark; ${ }^{2}$ \\ Animal Breeding and Genomics Centre, Wageningen University, P.O. Box 338, \\ 6700 AH Wageningen, The Netherlands
}




\section{Abstract}

In this study we assess the interchangeability and statistical agreement of two prevalent instruments from the non-invasive "sniffer" method and compare their precision. Furthermore, we develop and validate an effective algorithm for aligning time series data from multiple instruments to remove the effects of variable and fixed time shifts from the instrument comparison. The $\mathrm{CH}_{4}$ and $\mathrm{CO}_{2}$ gas concentrations for both instruments were found to differ for population means $(P<0.05)$ and intra-cow variation (precision) $(P<0.05)$ and for inter-cow variation $(\mathrm{P}<0.05)$. The $\mathrm{CH}_{4}$ and $\mathrm{CO}_{2}$ gas concentrations from both instruments can be used interchangeably to increase statistical power for example, in genetic evaluations, provided sources of disagreement are corrected through calibration and standardisation. Additionally, averaging readings of cows over a longer period of time (one week) is an effective noise reduction technique which provides phenotypes with considerable inter-cow variation.

Key words: Equivalence, Instrument comparison, Interchangeability, Methane, Sniffer, Statistical agreement 


\subsection{Introduction}

Methane $\left(\mathrm{CH}_{4}\right)$ is an abundant and potent greenhouse gas with a global warming potential substantially larger than that of carbon dioxide $\left(\mathrm{CO}_{2}\right)$ (IPCC, 2014). Dairy cattle through enteric methanogenesis contribute up to $20 \%$ of global livestock greenhouse gas emissions (Gerber et al., 2013). Research into mitigation strategies such as nutritional additives, housing, vaccination and genetic improvement has gained impetus in recent years. The assessment of strategies requires accurate and repeatable individual measurements under commercial conditions. Multiple instruments and or techniques have been developed to measure enteric $\mathrm{CH}_{4}$ intensity and emissions from cattle and other ruminants, each with their own scope of applications, merits and demerits (Hill et al., 2016). No single method is perfect in all aspects and thus in many instances a reference method from which to make comparisons is lacking. An emerging method for the measurement of $\mathrm{CH}_{4}$ and $\mathrm{CO}_{2}$ concentrations in the breath of dairy cattle, which is high throughput, non-invasive and viable in commercial conditions, is the "sniffer" method (Lassen et al., 2012;

Garnsworthy et al., 2012a). Air is continuously sampled from the concentrate bin of automated milking systems (AMS) during individual milking and sample gas concentrations recorded. Two prevalent instruments are the Gasmet DX4000 (Gasmet; Gasmet Technologies Oy, Helsinki, Finland) (Lassen et al., 2012; Haque et al., 2014) and the Guardian NG/Gascard (Guardian Plus; Edinburgh Instruments Ltd., Livingston, UK) (Garnsworthy et al., 2012a,b; Bell et al., $2014 a, b)$. While the techniques and calculations differ, with the former employing a prediction equation based on the ratio of the two gas concentrations and production traits (Madsen et al., 2010) and the latter utilising a scaling factor and methane emission rate (Garnsworthy et al., 2012a), both methods rely on gas concentration readings. The cost of non-invasiveness is restricting the animal to instrument interface and introducing sources of error and imprecision between readings due to air turbulence within the AMS and movement of the cows head in the AMS concentrate bin (Huhtanen et al., 2015). Repeating spot samples over a number of days to obtain a phenotype e.g. average gas concentrations over a week, reduces sources of error by a function of $1+t(n-1) / n$ where $t$ is the intra-class correlation (repeatability) and $n$ the number of records; thus obtaining a representative value cap- able of ranking animals (Hegarty, 2013; Hill et al., 2016). No comparative studies have 
been conducted on the two instruments to determine their equivalence or lack thereof.

Assessing the statistical agreement between instruments is crucial to informing the manner in which information from multiple instruments can be combined, for example, towards genetic evaluations. When measurements from both instruments on large-scale numbers of individuals are available, a genetic correlation between methods exceeding 0.8 is suitable to ascertain equivalence for genetic evaluations (Robertson, 1959). However, one may wish to establish agreement or lack thereof prior to measuring large numbers of individuals. According to Barnhart et al. (2007a), methods may disagree due to different population means, differing between-subject variances and differing within-subject variances. Population means can be corrected through calibrations, but different variances either require the more cumbersome instrument variance reduction or standardisation techniques (Barnhart et al., 2007a). As Bland and Altman (1999) pointed out, the partitioning of the random error variance into within-subject variances (imprecision) cannot be done without replicate measurements per subject per instrument. Analysing replicate measures on cows from AMS is challenging as the number of visits per cow to the AMS (replicates) is variable. Furthermore, time has elapsed between measures and thus the underlying biology has changed between measures due to factors such as diurnal variation patterns of $\mathrm{CH}_{4}$ and $\mathrm{CO}_{2}$ concentrations (Lassen et al., 2012). Thus replicate measures per cow must be taken simultaneously with each instrument and treated as paired observations i.e. "linked" replicates (Carstensen, 2011).

Choosing the correct indices to assess agreement must be done with care, for instance, despite having been discouraged for decades as being irrelevant and misleading, some authors still compute Pearson's correlation coefficient in method comparison studies (Altman and Bland, 1983; Bland and Altman, 1986; Carstensen, 2011). Even if one of the methods is perfect, it will correlate poorly to a second less precise method (Barnhart et al., 2007a). Likewise, unscaled agreement indices such as the coefficients of variation within- and between-animals, as well as scaled agreement indices such as Lin's three forms of concordance correlation coefficients (CCC) and intra-class correlations coefficients (ICC), are reliant on between-animal variance. Therefore, imprecise methods recorded on heterogeneous populations will still appear to agree favourably (Barnhart et al., 2007a). An agreement index suited to repeated measures with large errors and less reliance on population heterogeneity is the coefficient of individual agreement (CIA) (Barnhart et al., 2007b). Methods are regarded as interchangeable only if individual measurements 
between instruments are similar to replicated measures within instrument (Barnhart et al., 2007a).

An additional challenge when comparing instruments with time-stamped measurements, is the clock synchronisation problem, where clocks can have fixed and variables shifts in time (Ridoux and Veitch, 2007). In the absence of synchronised time stamping, as is often the case when comparing readings from multiple instruments, it is possible to obtain a misleading result. Even the most precise instrument will compare poorly when timestamped by an inaccurate clock.

The objectives of this paper were: (1) Demonstrate a fast method for detecting fixed and variable shifts in time series. (2) Conduct a method comparison analysis in the presence of linked and variable number of replicates from each instrument. (3) Standardise instrument recordings to achieve satisfactory agreement for joint analysis.

\subsection{Materials and methods}

\subsubsection{Design animals and feeding}

Data was recorded over a three week period from end of April to mid May 2015 at the Danish Cattle Research Centre (DCRC, Foulum, Denmark). A total of 56 Holstein cows, average body weight $686.6 \pm 86.5 \mathrm{~kg}$ (mean $\pm \mathrm{sd}$ ), milk production $38.4 \pm 0.34 \mathrm{~kg} /$ day roughage dry matter $20.47 \pm 4.43 \mathrm{~kg} /$ day and concentrates $2.5 \pm$ $0.28 \mathrm{~kg} /$ day were recorded during the experimental period. Cows were of mixed parity $44 \% 1$ st parity, $35 \%$ 2nd parity, $21 \%$ 3rd parity at mixed stages of lactation 36\% early, 27\% mid and 38\% late (14-100 DIM early, 100-200 DIM mid, 200-305 late). The DCRC barn is a free stall housing system with cubicles. Cows had access to an AMS (DeLaval International AB, Tumba, Sweden) where they were provided up to $3 \mathrm{~kg}$ of concentrate a day within the concentrate bin. Cows were offered a TMR consisting of corn silage, rapeseed meal and soybean meal ad libitum in individualised feeding troughs (RIC-system, Insentec, Marknesse, The Netherlands). Data on feed intake (concentrate and roughage), weight and milk production are recorded continuously at the DCRC. The study was conducted without altering management protocols or feeding schemes conducted at the research centre. Cows had free access to AMS with a minimum visit cycle limitation of $4 \mathrm{~h}$, except during the two daily automated cleaning cycles. Cows presented for milking on average 2.4 \pm 0.86 visits/day (mean $\pm \mathrm{sd}$ ) during the trial period. The data in this study is generated on cows performing under typical commercial conditions which are representative of a general dairy cattle population in Denmark. 


\subsubsection{Breath sampling analysis}

$\mathrm{CH}_{4}$ and $\mathrm{CO}_{2}$ gas concentrations are routinely analysed at DCRC by using infrared gas analysers installed within each AMS (Guardian NG/Gascard, Edinburgh Instruments Ltd, Livingston, UK) with a range of $0-1 \% \mathrm{CH}_{4}$ and $0-5 \% \mathrm{CO}_{2}$ and logged with NOVUS FIELD LOGGER software (NOVUS Automation, www.fieldlogger.net). The air inlet was custom installed in the upper left rear side of the AMS feed bin so as to be aligned with the nostrils of a feeding cow as per the second experiment described by Garnsworthy et al. (2012a). Air is sampled continuously at a rate of 1 $\mathrm{L} / \mathrm{min}$ through a $4 \mathrm{~mm}$ polyurethane tube approximately $3 \mathrm{~m}$ in length with an inline particulate filter to remove dust and a permeable tube with pressurised dehumidified air to remove water vapour before reaching the sensors. The exhaust port of the analyser is vented a minimum of $3 \mathrm{~m}$ clear of any sampling point. Data is logged at $1 \mathrm{~s}$ intervals and stored perpetually though the use of remote access. Sensors were calibrated prior to the experiment by flushing the sensor inlet with a calibration gas containing $0.0 \% \mathrm{CH}_{4}$ and $0.0 \% \mathrm{CO}_{2}$ to set the lower range and then flushed with a calibration gas containing $1.0 \% \mathrm{CH}_{4}$ and $3.0 \% \mathrm{CO}_{2}$ to set the upper range (both gases in synthetic air HiQ 4.0; AGA, Fredericia, Denmark). Sensors were installed for the recording of entry and exit times within the same time series as the continuous gas concentrations.

The portable Fourier transformed infrared analyser FTIR (Gasmet DX 4000, Gasmet Technologies Oy, Helsinki, Finland) was installed at DCRC as per methods used for sampling through-out Denmark (Lassen and Løvendahl, 2016). The inlet was installed within the feed bin of the AMS in a manner analogous to the Guardian with the exception that the location was in the upper right rear of the bin to mirror and the inlet of the Guardian, in order to prevent the differential pumping rates from creating turbulence at the inlets. Air was sampled continuously through the integral pump at a rate of $4 \mathrm{~L} / \mathrm{min}$, starting with an inline particulate filter at the inlet via a 5 $\mathrm{m}$ long hose heated to $180{ }^{\circ} \mathrm{C}$ before entering the sensor unit. The exhaust gases were vented more than $3 \mathrm{~m}$ away from any sampling points. Data was logged continuously at 5 s intervals using Calcmet Software and stored on an integral laptop, thus the Guardian and Gasmet data was timestamped by different data logger software on different servers. The analyser provides reading for the multiple gases as well as water vapour, external and internal temperatures, $\mathrm{CH}_{4}$ at a range of $0.0-$ $0.5 \%$ and $\mathrm{CO}_{2}$ at a range of $0.0-5.0 \%$ (Teye et al., 2009). Prior to the start of the experiment, the inlet pipe heating elements are heated to $180{ }^{\circ} \mathrm{C}$ and the sensor chamber is flushed out with $100 \%$ nitrogen gas for 0 point calibration. The identification number (ID) of the cow, start and exit time of the first visit to the AMS 
after installation and calibration, is recorded to facilitate alignment with AMS data and determine initial fixed differences between time series.

The AMS records cow ID as well as total yield, status of visit, entry and exit times. Thus the AMS data is a third time series, time stamped by a separate server. Twice daily the AMS enters into an automated cleaning cycle of approximately 30 min in duration, during which no cow can enter the AMS. The cleaning cycles occur between 3:30 and 5:00 as well as 15:50 and 17:00 daily. The values recorded during the morning cleaning cycle are used to determine the ambient concentrations (Baseline) of $\mathrm{CO}_{2}$ and $\mathrm{CH}_{4}$ for each day.

\subsubsection{Algorithm steps for prediction of cow entry times and head lifting}

In order to align all three time series datasets to a common time, it was first necessary to account and correct for the fixed or variable time shifts between the servers used to timestamp the records. Since a cow exhaling into the concentrate bin of the AMS is accompanied by sudden and large changes in the concentrations of gases recorded by both instruments, it is possible to identify cow entry times in the datasets of the two instruments and align with the entry times of the AMS dataset. The algorithm used to identify cow entry was undertaken in progressive steps in the analysis. Firstly, the algorithm used Holt's double exponential smoothing to establish a time step to time step smoothed value, slope and forecast of $\mathrm{CO} 2$ gas concentrations for both instruments. Then the detection of cow entry was based upon the smoothed value and slope. An added benefit of the algorithm is it enables the filtering of data when the cow is deemed (indirectly) to have lifted its head in a manner similar to that implemented by Garnsworthy et al. (2012a) and Huhtanen et al. (2015). See Appendix A for a detailed description of the algorithm.

\subsubsection{Gas concentration variables}

Both the Guardian and the Gasmet series were brought into time alignment with the AMS dataset and expanded. The data where the cow's head is predicted to be out of the feed bin was filtered and means of $\mathrm{CO} 2$ and $\mathrm{CH} 4$ concentrations for each AMS visit were calculated for further analysis. Furthermore, the AMS time for the start of each visit was converted to $24 \mathrm{~h}$ angular radians and modelled in a Fourier series approach and ambient gas concentrations from the AMS morning cleaning cycles stored (Løvendahl and Bjerring, 2006; Lassen et al., 2012). 


\subsubsection{Statistical analysis}

Gas concentration data from both instruments was transformed by means of a natural logarithmic transformation to meet the requirements of normality of residuals. Data was analysed using linear mixed effects (LME) models with Kronecker product covariance structure in a doubly multivariate set-up (Hamlett et al., 2004; Roy, 2009), by means of the MIXED procedure of SAS with repeated measures linked through time (ver. 9,3; SAS Institute Inc., Cary, NC). A Kenward-Roger correction was utilised for computing the correct denominator degrees of freedom of fixed effects in the presence of repeated measures (Kenward and Roger, 1997). As the number of replicate measures per cow per day can vary from 2 to 5 and may not be equal between cows, the number of replications by each method on each cow is equal to $p_{i}$. Therefore, the number of observations on the ith subject $n_{i}$ is $2 p_{i}$. The LME for the ith cow can be written as:

$$
\begin{aligned}
y_{i}=\beta_{0}+\beta_{1} M_{i 1} & +\beta_{2} M_{i 2}+\beta_{3} \text { Date }+\sum_{g=1}^{3}\left[f_{1 g} \sin \emptyset+f_{2 g} \cos \emptyset\right]+\beta_{6} \text { Base } \\
& +b_{1 i} Z_{i 1}+b_{2 i} Z_{i 2}+\epsilon_{i}
\end{aligned}
$$

where every method replication response is denoted by subscript $i$, terms $M_{i 1}$ and $M_{i 2}$ indicate the instrument each response belongs to. The regression coefficients $b_{0}$ is the intercept, $b_{1}$ and $b_{2}$ are the respective fixed effects of instruments, $b_{3}$ is the fixed effect of date of measurement, $f_{1 g}$ and $f_{2 g}$ are fixed regression coefficients of Fourier series linear covariates of the time of day of measurement. Symbols $\varnothing$ denote the time of day as angular radians. $b_{6}$ is a fixed regression coefficient on the linear covariate of the daily background gas concentrations during the morning AMS cleaning cycle. Terms $b_{1 i}$ and $b_{2 i}$ are random effect parameters for each of the two instruments and $Z_{i 1}$ and $Z_{i 2}$ relate responses $y_{i}$ to methods. The above equation can be re-written in matrix notation equations for further clarification:

$$
y_{i}=X_{i} \beta+Z_{i} b_{i}+\epsilon_{i}
$$

with

$$
b_{i} \sim N_{m}(0, D)
$$

and

$$
\epsilon_{i} \sim N_{n i}\left(0, R_{i}\right)
$$


where $\left(y_{i}\right)$ is all the responses of the $i$ th cow, modelled as dependent on systematic effects $b$ given design matrix of fixed effects $X_{i}$, described for the equation above. Random effects of each instrument across cows is given by $b_{i}$ with incidence matrix $Z_{i}$. Variance-covariance matrix $D$ gives between cow variation and variancecovariance matrix $R_{i}$ gives within cow sources of variation.

The method described in detail by Roy (2009) was employed to formally test the significance of differences for the between- subject, within-subject and total variances of the two instruments by means of log likelihood ratio tests between models differing for various combinations of structured or unstructured varianceco-variance matrices $D$ and $R_{i}$. The CIA was calculated as per Barnhart et al. (2007a) for comparisons without a reference method.

Once sources of disagreement were identified, the $\left(y_{i}\right)$ responses of the Gasmet were calibrated and standardised to that of the Guardian mean and total variance for both gases by means of STANDARD procedure in SAS. The aforementioned models were re-run to evaluate the effects of calibration and standardisation on measurement agreement, the results of which are summarised in Table 2.2. Furthermore, the sum of the intercepts, random solutions and residuals for each instrument and gas variable was taken as the per visit gas concentration corrected for daily background, time of day and date. The corrected per visit gas concentrations were then used to calculate the mean corrected gas concentration per day and the mean corrected daily concentrations per week. A reduced version of the model equation above only including fixed effects of day or week of measurement was utilised to estimate means and variances of the averaged gas phenotypes, the results of which can be found in Table 2.3 below.

\subsection{Results and discussion}

\subsubsection{Time series alignment}

The alignment algorithm correctly identified a fixed time difference of $1 \mathrm{~h}$ between the Guardian time series and AMS time series due to inconsistent Daylight Saving Time (DST) implementation. Furthermore, a 320 s fixed difference was correctly identified between the Gasmet time series and AMS time series as per the differences between the start times recorded for the first cow after installation. The variable component of time drift between the time series of both instruments, the door sensors in the Guardian time series and the AMS time series can be seen in Fig. 1 below. 


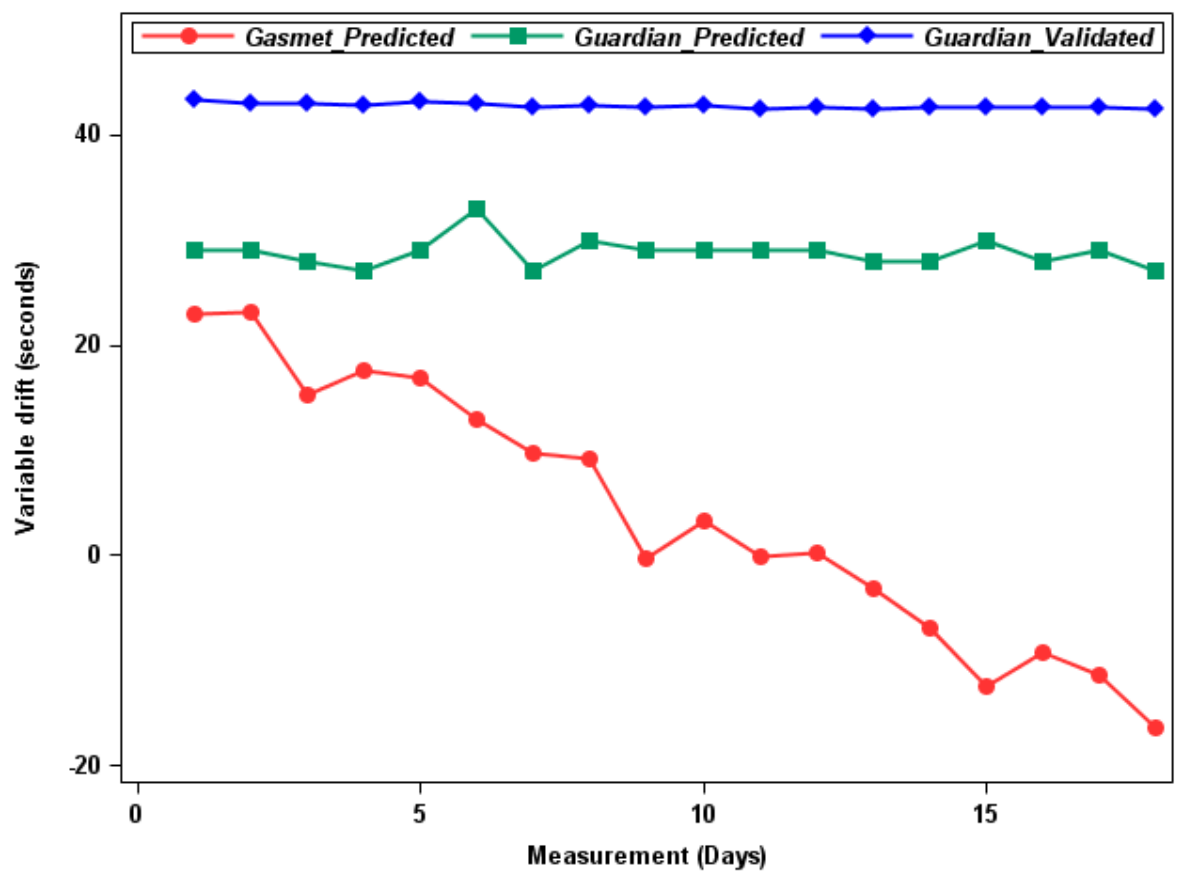

Figure 2.1 Variable clock drift between instrument time series (Gasmet_Predicted \& Guardian_Predicted), Guardian door sensors (Guardian Validation) and AMS time in seconds.

For the Guardian, the prediction algorithm correctly identified the variable drift with a constant difference of $8 \pm 4 \mathrm{~s}$ as compared with the door sensors in the AMS. The constant difference is attributed to the lag in time between the door opening and the first air sample containing the cow's breath reaching the gas sensor. The Gasmet time series drifted approximately $1 \mathrm{~s}$ per day whereas the Guardian time series drifted approximately $0.2 \mathrm{~s}$ per day. For the Guardian time series the detection rate of the alignment algorithm was verified at $97 \%$ for fixed and constant drift on a daily basis as compared to the door sensors. For the Gasmet only the observed (fixed) difference between the time series for the first day was possible. The alignment algorithm greatly improves the alignment of gas concentration signal with the associated cow accounting for fixed time shifts and variable time shifts. Thus the algorithm removes a potential source of bias and error from the subsequent instrument comparisons. A plot of sample data for $\mathrm{CH}_{4}$ concentrations (PPM) for four cow visits from both instruments after alignment can be found in Fig. 2 below. A visual inspection of Fig. 2 reveals that whilst visible differences exist between 
instrument readings, variable and fixed time drift are no longer a contributing factor to differences between instruments.

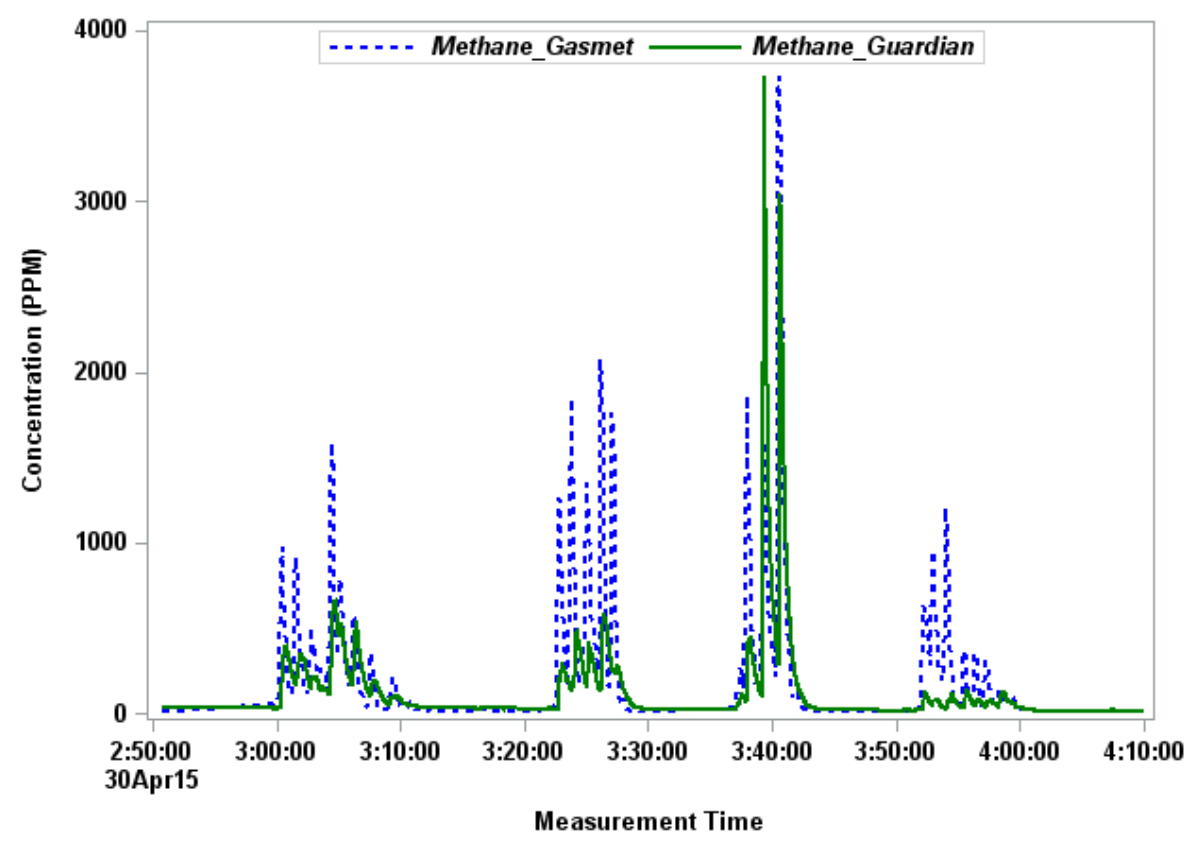

Figure $2.2 \mathrm{CH}_{4}$ gas signal for multiple cow visits after time alignment Guardian NG (Green solid line) Gasmet (Blue dashed line)

\subsubsection{Instrument comparison, calibration and standardisation}

The population means and all variance components differed $(P<0.05)$ for both gas concentrations between instruments (Table 2.1). As neither method is the reference method, we cannot report which instrument has the most accurate population means for either of the gas concentrations reported. The ICC estimates are moderate and similar in magnitude for each of the instruments and gas concentrations. Furthermore, they are directly comparable with those reported by Lassen et al. (2012) for the mean Gasmet gas concentrations on a per visit basis. Though discouraged in comparisons studies, we provide the Pearson's correlation coefficients, which were moderate and positive between instruments for both gases. Considering that all sources of (dis)agreement differed significantly, it is not surprising that the $\mathrm{CIA}$ estimates are moderate and low for $\mathrm{CH}_{4}$ and $\mathrm{CO}_{2}$ concentrations respectively, with the estimate for $\mathrm{CO}_{2}$ being particularly poor and worse than for $\mathrm{CH}_{4}$. Based on the criteria for statistical agreement of equivalence of 
Table 2.1 Sources of (dis)agreement for $\mathrm{CH}_{4}$ and $\mathrm{CO}_{2}$ concentrations per AMS visit after common time alignment

\begin{tabular}{lllll}
\hline & \multicolumn{2}{l}{$\begin{array}{l}\text { Methane concentration In(PPM) } \\
\text { Guardian }\end{array}$} & Gasmet & \multicolumn{2}{l}{$\begin{array}{l}\text { Carbon Dioxide concentration In(PPM) } \\
\text { Gasdian }\end{array}$} \\
\hline Mean \pm S.E. & $6.808^{\mathrm{a}} \pm 0.0176$ & $6.564^{\mathrm{b}} \pm 0.0292$ & $8.478^{\mathrm{a}} \pm 0.0371$ & $9.128^{\mathrm{b}} \pm 0.0239$ \\
Inter-Cow Variation & $0.017^{\mathrm{a}}$ & $0.045^{\mathrm{b}}$ & $0.075^{\mathrm{a}}$ & $0.031^{\mathrm{b}}$ \\
Intra-Cow Variation & $0.026^{\mathrm{a}}$ & $0.091^{\mathrm{b}}$ & $0.080^{\mathrm{a}}$ & $0.035^{\mathrm{b}}$ \\
Total Variation & $0.042^{\mathrm{a}}$ & $0.136^{\mathrm{b}}$ & $0.155^{\mathrm{a}}$ & $0.066^{\mathrm{b}}$ \\
Intra-Class Correlations & $0.39^{\mathrm{a}}$ & $0.33^{\mathrm{a}}$ & $0.48^{\mathrm{a}}$ & $0.47^{\mathrm{a}}$ \\
Pearson's Correlation & & 0.55 & & 0.44 \\
CIA & \multicolumn{2}{c}{0.54} & 0.18 \\
\hline
\end{tabular}

a,b estimates with subscripts differ $(P<0.05)$ 
means and total variability suggested by Roy (2009), and the threshold of "good" interchangeability (0.455) defined by Barnhart et al. (2007b), we can see that $\mathrm{CH}_{4}$ measures of both instruments can be used interchangeably but the $\mathrm{CO}_{2}$ cannot, without further remedy to the sources of disagreement.

After calibration and standardisation of the Gasmet measurements to those of the Guardian it can be seen that the population means, inter-cow variation and total variation no longer differ $(P>0.05)$ (Table 2.2). While lack of a reference method precludes inference about the accuracies, inference about precision is possible using the intra-cow variation. The intra-cow variation differed $(P<0.05)$ for both $\mathrm{CH}_{4}$ and $\mathrm{CO}_{2}$ between instruments, with the Gasmet having marginally higher estimates for both gases. The ICCS and Pearson's correlations are very similar to those computed before calibration and standardisation as they are largely unaffected by calibrations and variance scaling. The $\mathrm{CIA}$ estimates for $\mathrm{CH}_{4}$ and $\mathrm{CO}_{2}$ increased substantially with $145 \%$ and $356 \%$ increases respectively, and were thus more similar for $\mathrm{CH}_{4}$ than for $\mathrm{CO}_{2}$. Using the criteria of statistical agreement and interchangeability we see that for $\mathrm{CH}_{4}$ and $\mathrm{CO}_{2}$ the instruments can be used interchangeably. It will thus be beneficial to combine datasets from both instruments in the interests of increasing statistical power.

The descriptive statistics, ICC and Pearson's correlations for mean visit concentration per day and per week, after standardisation and calibration, are contrasted for $\mathrm{CH}_{4}$ and $\mathrm{CO}_{2}$ in Table 2.3 below. The population means do not differ for all pairs of gas concentration variables. The ICC estimates increase with each increase in time and thus, number of visits used to estimate mean values. The intracow variation decreased as a function of $1+r(n 1) / n$ where $r$ is the intra-class correlation and $\mathrm{n}$ is the number of repeated measures thus, the effect of noise is reduced while the animal variance remains constant i.e. averaging out imprecision.

The ICC estimates for $\mathrm{CH}_{4}$ and $\mathrm{CO}_{2}$ of the Guardian are in the order of magnitude of those reported by Bell et al. (2014b) for a similar phenotype estimated on per week of lactation basis. Differences between instruments were expected as instruments differed on multiple technical aspects e.g. gas concentration sensitivity ranges, differential pumping rates, differential sensitivities to temperature and humidity, etc. Moreover the Guardian instrument in this study is dedicated solely to measuring $\mathrm{CH}_{4}$ and $\mathrm{CO}_{2}$ intensities, whereas the Gasmet records and transforms IR spectra into ten different gases including $\mathrm{CH}_{4}$ and $\mathrm{CO}_{2}$. Auto-correlations between flanking spectral regions could be the cause of the marginal increase in imprecision observed with the Gasmet instrument. 
Table 2.2 Sources of (dis)agreement for $\mathrm{CH}_{4}$ and $\mathrm{CO}_{2}$ concentrations per AMS visit after common time alignment, calibration and standardization

\begin{tabular}{lllll}
\hline & \multicolumn{2}{l}{ Methane concentration In(PPM) } & \multicolumn{2}{l}{ Carbon Dioxide concentration In(PPM) } \\
& Guardian & Gasmet & Guardian & Gasmet \\
\hline Mean \pm S.E. & $6.806^{\mathrm{a}} \pm 0.0178$ & $6.791^{\mathrm{a}} \pm 0.0169$ & $8.479^{\mathrm{a}} \pm 0.0169$ & $8.439^{\mathrm{a}} \pm 0.0371$ \\
Inter-Cow Variation & $0.017^{\mathrm{a}}$ & $0.015^{\mathrm{a}}$ & $0.074^{\mathrm{a}}$ & $0.075^{\mathrm{a}}$ \\
Intra-Cow Variation & $0.028^{\mathrm{a}}$ & $0.031^{\mathrm{b}}$ & $0.078^{\mathrm{a}}$ & $0.086^{\mathrm{b}}$ \\
Total Variation & $0.045^{\mathrm{a}}$ & $0.046^{\mathrm{a}}$ & $0.151^{\mathrm{a}}$ & $0.161^{\mathrm{a}}$ \\
Intra-Class Correlations & 0.38 & 0.33 & 0.49 & 0.46 \\
Pearson's Correlation & & 0.49 & & 0.42 \\
CIA & & 0.78 & & 0.65 \\
\hline
\end{tabular}

$\overline{a, b}$ estimates with subscripts differ $(P<0.05)$ 
Table 2.2 Average daily and weekly gas concentrations for standardised measurements

\begin{tabular}{lcccc}
\hline & \multicolumn{2}{c}{ Methane Concentration } & \multicolumn{2}{c}{ Carbon Dioxide Concentration } \\
& Guardian & Gasmet & Guardian & Gasmet \\
\hline Mean Visit per Day Ln(PPM) & & & & \\
Mean \pm S.E. & $6.658^{\mathrm{a}} \pm 0.018$ & $6.641^{\mathrm{a}} \pm 0.017$ & $8.313^{\mathrm{a}} \pm 0.037$ & $8.272^{\mathrm{a}} \pm 0.037$ \\
Inter-Cow Variation & 0.017 & 0.016 & 0.074 & 0.072 \\
Intra-Cow Variation & 0.012 & 0.015 & 0.036 & 0.050 \\
Intra-Class correlations & 0.58 & 0.51 & 0.67 & 0.58 \\
Pearson's correlation & 0.45 & & 0.41 & $8.273^{\mathrm{a}} \pm 0.0371$ \\
Mean Visit per week Ln(PPM) & & & 0.071 \\
Mean \pm S.E. & $6.655^{\mathrm{a}} \pm 0.018$ & $6.642^{\mathrm{a}} \pm 0.017$ & $8.307^{\mathrm{a}} \pm 0.037$ & 0.074 \\
Inter-Cow Variation & 0.016 & 0.016 & 0.012 & 0.018 \\
Intra-Cow Variation & 0.003 & 0.005 & 0.87 & 0.80 \\
Intra-Class correlations & 0.84 & 0.47 & & 0.42 \\
Pearson's correlation & 0.49 & & & \\
\hline
\end{tabular}

$\overline{a, b}$ estimates with subscripts differ $(P<0.05)$ 


\subsection{Conclusion}

We detected fixed and variable shifts in time series between instruments and our algorithm was effective in aligning data series to a common clock time on a per day basis. Instead of genetic correlations between measurements exceeding 0.8 or simultaneous measurements with a reference method, we make use of statistical agreement and interchangeability to assess equivalence of methods. Measurements of $\mathrm{CH}_{4}$ and $\mathrm{CO}_{2}$ from both instruments can be used interchangeably provided sources of disagreement are identified and corrected for by means of calibration and standardisation. However, simultaneous repeated measures on multiple cows by both instruments are required to identify sources of disagreement. The ICC estimates show the inter-cow variation is considerable, particularly with measurements recorded over a one week period and is encouraging for genetic improvement of the phenotype. It is pertinent to note, the phenotypes estimated here are gas concentrations and not absolute emissions. Further comparisons between techniques which estimate emissions from concentration are required.

\subsubsection{Conflicts of Interest}

The authors have no affiliation with either company producing instruments and have no conflicts of interest to declare.

\subsubsection{Acknowledgements}

The authors would like to thank the staff at DCRC for their assistance and Mr. M. Bjerring for assistance in installation and maintenance of instruments. G.F. Difford benefited from an Erasmus-Mundus fellowship and a grant by the Innovation Fund Denmark project REMRUM, within the framework of the European Graduate School in Animal Breeding and Genetics. The authors would like to express gratitude to the EU COST-action METHAGENE network for the interesting discussions and input.

\subsection{Appendix}

\subsubsection{Algorithm steps for prediction of cow entry times and head lifting}

Step 1: Holt's double exponential smoothing:

The smoothed value $\left(\bar{L}_{t}\right)$, slope $\left(\bar{b}_{t}\right)$, and forecast $\left(\bar{F}_{t+1}\right)$ of $\mathrm{CO}_{2}$ gas concentrations for both instruments for each time point were established: 


$$
\begin{gathered}
\bar{L}_{t}=\alpha y_{t}+(1-\alpha)\left(\bar{L}_{t-1}+\bar{b}_{t-1}\right) \\
\bar{b}_{t}=\beta\left(\bar{L}_{t}-\bar{L}_{t-1}\right)+(1-\beta) \bar{b}_{t-1} \\
\bar{F}_{t+1}=\bar{L}_{t}+\bar{b}_{t}
\end{gathered}
$$

The smoothing factors $\alpha$ and $\beta$ gives relative weights to new information and was determined by means of a grid search though parameter space 0 to 1 to increments of 0.1 to minimize the Mean Square Forecast Error (MSFE):

$$
M S F E=\sum_{i=1}^{t}\left(\bar{F}_{t}-y_{t}\right)^{2} / t
$$

Step 2: Deviations from Smoothed Value:

For each time step, the deviation between the observed $\mathrm{CO}_{2}$ concentration and the smoothed value was calculated as the square of the simple difference:

$$
\bar{x}_{t}{ }^{2}=\left(y_{t}-\bar{L}_{t}\right)^{2}
$$

Step 3: Detection of Cow entry:

The square deviations of smoothed value were expected to be nearly free of diurnal variations and thus reach 0 between cow visits. Therefore square deviations exceeding a threshold $(\delta)$ indicated a sudden change. A rule was applied whereby a reading exceeding the threshold with three past square deviations below the threshold, along with three consecutively increasing slope values, was defined as the start of a cow entry.

Step 4: Detection of cow head lifting:

A second threshold $(\phi)$ was defined as the upper $95 \%$ confidence interval from the ambient $\mathrm{CO} 2$ concentrations found during the morning AMS cleaning cycles. If the slope increased for three consecutive time steps followed by three decreasing time steps, it was defined as a peak. Thus readings must contain peaks and the smoothed value exceeding the threshold $(\phi)$ to be defined as cow head inside the bin.

Step 5: Calculation of time displacement:

The time elapsed between each predicted cow entry point and the successive predicted entry point was extracted and stored in an $n \times 2$ array, where $n$ is the total number of predicted visits. Similarly, the time elapsed between each AMS entry time and the successive entry time was extracted and stored in a separate $\mathrm{n} x$ 2 array where $n$ is the number of visits. For both arrays each row was summed and 
match merged by use of SQL Procedure in SAS with a tolerance of 20 seconds and added limitation that matches must have the same date. Three consecutive correctly predicted cow entries are required to achieve a match with three consecutive AMS cow entry times. The difference between the times of the predicted cow entry and the AMS cow entry gives the time displacement between each time series. Time displacement estimates are further filtered by narrowing the range of displacement to +/- (01:01:00 hours) allowing for clock changes at Daylight Saving Time onset and reset. The mean of all displacement estimates for each day are then subtracted from the time variable of one of the datasets to bring the time series into 'common time' and allow merging by time.

Step 6: Optimization and validation:

A subset of the data from each instrument was used as a training set to optimize thresholds for cow entry prediction. This consisted of the 3:00 to 6:00 period during which a cleaning cycle occurred and readings are assumed to have fallen to ambient barn concentrations, and the 10:00 until 13:00 when many milkings follow in quick succession and thus readings between milkings are assumed to not always have fallen to ambient levels. If the threshold $(\delta)$ is set too high the detection rate in the later subset is low. Conversely, if the threshold is too low multiple false positives are predicted within each visit. Since the two scenarios are antagonistic, an optimization was performed. The $\alpha=0.9, \beta=0.1, \delta=500$ and $\phi$ ranged between 600 and 1000 for both instruments.

The Guardian had integral door sensor readings from the gates of the AMS. A $2 \times n$ array was constructed as per those above and match merged to the array from the AMS dataset. The displacement between the door sensors and AMS was then utilized as a known time displacement to validate the algorithm for the Guardian dataset only.

\section{References}

Altman, D.G., Bland, J.M., 1983. Measurement in medicine: the analysis of method comparison studies. Statistician 32, 307-317.

Barnhart, H.X., Haber, M.J., Lin, L.I., 2007a. An overview on assessing agreement with continuous measurements. J. Biopharm. Stat. 17 (4), 529-569.

Barnhart, H.X., Haber, M., Lokhnygina, Y., Kosinski, A.S., 2007b. Comparison of concordance correlation coefficient and coefficient of individual agreement in assessing agreement. J. Biopharm. Stat. 17 (4), 721-738. 
Bell, M.J., Potterton, S.L., Craigon, J., Saunders, N., Wilcox, R.H., Hunter, M., Goodman, J.R., Garnworthy, P.C., 2014a. Variation in enteric methane emissions among cows on commercial dairy farms. Animal 8 (9), 1540-1646.

Bell, M.J., Saunders, N., Wilcox, R.H., Horner, E.M., Goodman, J.R., Craigon, J., Garnsworthy, 2014b. Methane emissions among individual dairy cows during milking quantified by eructation peaks or ratio with carbon dioxide. J. Dairy Sci. 97, 6536-6546.

Bland, J.M., Altman, D.G., 1986. Statistical methods for assessing the agreement between two methods of clinical measurement. Lancet $i, 307-310$.

Bland, J.M., Altman, D.G., 1999. Measuring agreement in method comparison studies. Stat. Methods Med. Res. 8, 135-160.

Carstensen, B., 2011. Comparing Clinical Measurement Methods: a Practical Guide, vol. 108. John Wiley \& Sons.

Garnsworthy, P.C., Craigon, J., Hernandez-Medrano, J.H., Saunders, N., 2012a. Onfarm methane measurements during milking correlate with total methane production by individual dairy cows. J. Dairy Sci. 95, 3166-3180.

Garnsworthy, P.C., Craigon, J., Hernandez-Medrano, J.H., Saunders, N., 2012b. Variation among individual dairy cows in methane measurements made on farm during milking. J. Dairy Sci. 95, 3181-3189.

Gerber, P.J., Steinfeld, H., Henderson, B., Mottet, A., Opio, C., Dijkman, J., Falcucci, A., Tempio, G., 2013. Tackling Climate change Through Livestock - a Global Assessment of Emissions and Mitigation Opportunities. Food and Agriculture Organization of the United Nations (FAO), Rome.

Haque, M.N., Cornou, C., Madsen, J., 2014. Individual variation and repeatability of methane production from dairy cows estimated by the $\mathrm{CO} 2$ method in automatic milking system. Animal, 1-10.

Hamlett, A., Ryan, L., Wolfinge, R., 2004. On the use of PROC MIXED to estimate correlation in the presence of repeated measures. In: SAS Users Group International, Proceedings of the Statistical and Data Analysis Section, Paper 19829, pp. 1-7.

Hegarty, R.S., 2013. Applicability of short-term emission measurements for on-farm quantification of enteric methane. Animal 7 (s2), 401-408.

Hill, J., McSweeney, C., Wright, A.G., Bishop-Hurley, G., Kalantar-zadeh, K., 2016. Measuring methane production from ruminants. Trends Biotechnol. 34 (1), 26-35. Huhtanen, P., Cabezas-Garcia, E.H., Utsumi, S., Zimmerman, S., 2015. Comparison of methods to determine methane emissions from dairy cows in farm conditions. J. Dairy Sci. 98, 3394-3409. 
IPCC, 2014. Climate Change 2014: Synthesis Report. In: Core Writing Team, Pachauri, R.K., Meyer, L.A. (Eds.), Contribution of Working Groups Im II and III to the Fifth Assessment Report of the Intergovernmental Panel on Climate Change. IPCC, Geneva, Switzerland, p. 51.

Kenward, M.G., Roger, J.H., 1997. Small sample inference for fixed effects from restricted maximum likelihood. J. Biometrics 53, 983-997.

Lassen, J., Løvendahl, P., Madsen, J., 2012. Accuracy of non-invasive breath measurements using Fourier transform infrared methods on individual cows. J. Dairy Sci. 95, 890-898.

Lassen, J., Løvendahl, P., 2016. Heritability estimates for enteric methane production in dairy cattle using non-invasive methods. J. Dairy Sci. 99, 1959-1967.

Løvendahl, P., Bjerring, M.A., 2006. Detection of carryover in automated milk sampling equipment. J. Dairy Sci. 89 (9), 3645-3652.

Madsen, J., Bjerg, B.S., Hvelplund, T., Weisbjerg, M.R., Lund, P., 2010. Methane and carbon dioxide ratio in excreted air for quantification of methane production in ruminants. Livest. Sci. 129, 223-227.

Ridoux, J., Veitch, D., 2007. A methodology for clock benchmarking. In: Testbeds and Research Infrastructure for the Development of Networks and Communities, 2007. TridentCom 2007. 3rd International Conference on. IEEE, pp. 1-10.

Robertson, A., 1959. The sampling variance of the genetic correlation coefficient. Biometrics 15 (3), 469-485.

Roy, A., 2009. An application of linear mixed effects model to assess the agreement between two methods with replicated observations. J. Biopharm. Stat. 19, 150173.

Teye, F.K., Alkkiomaki, E., Simojoki, A., Pastell, M., Hautala, M., Ahokas, J., 2009. Instrumentation, measurement and performance of three air quality measurement systems for dairy buildings. Appl. Eng. Agric. 25, 247-256. 




\section{Chapter 3}

\section{Rapid Communication: Ranking cows' methane emissions under commercial conditions with sniffers versus respiration chambers}

G.F. Difford ${ }^{1,2}$, D. W. Olijhoek ${ }^{2,3}$, A. L. F. Hellwing 3 , P. Lund ${ }^{3}$, Y. de Haas², J. Lassen $^{1}$, P. Løvendahl ${ }^{1}$

${ }^{1}$ Department of Molecular Biology and Genetics, Faculty of Science and Technology, Aarhus University, PO Box 50, DK-8830 Tjele, Denmark; ${ }^{2}$ Animal Breeding and Genomics Centre, Wageningen University, P.O. Box 338, $6700 \mathrm{AH}$ Wageningen, The Netherlands; ${ }^{3}$ Department of Animal Science, Aarhus University, AU-Foulum, P.O. Box 50, DK-8830 Tjele, Denmark 


\section{Abstract}

The objective of the study was to assess the ranking of dairy cows using individual level correlations for methane $\left(\mathrm{CH}_{4}\right)$ emission phenotypes on-farm using sniffers and in respiration chambers. In total 20 lactating dairy cows, ten Danish Holstein and ten Danish Jerseys were recorded for three weeks of lactation prior to relocation and acclimation at the respiration chamber (RC) facility where they were each recorded on three occasions within the RC. Pairwise bivariate linear mixed models were used to determine the individual level correlations $\left(r_{1}\right)$ between sniffer phenotypes and RC phenotypes as proxies for genetic correlations. Despite differences in feeding and management, the predicted $\mathrm{CH}_{4}$ production on farm from sniffers correlated well with $\mathrm{CH}_{4}$ production in the $\mathrm{RC}\left(\mathrm{CH}_{4} \_\mathrm{RC}\right) r_{1}=0.77 \pm 0.18$ and the direct $\mathrm{CH}_{4}$ breath concentration ( $\mathrm{CH} 4 \_\mathrm{C}$ ) correlated nearly as well with $\mathrm{CH} 4 \mathrm{RC}_{r_{1}}=0.75 \pm 0.20$. The correlations between $\mathrm{CH}_{4}$ emission phenotypes on-farm from sniffers and CH4_RC exceeded that of energy corrected milk yield, live weight and dry matter intake demonstrating the potential of sniffers measurements as largescale indicator traits for $\mathrm{CH}_{4}$ emissions in dairy cattle.

Key words: Methane, sniffers, breath concentration, respiration chambers 


\subsection{Introduction}

Methane $\left(\mathrm{CH}_{4}\right)$ is a potent greenhouse gas produced by dairy cattle and other ruminants as a natural by-product of fermentation. Research on numerous mitigation strategies such as nutritional additives, vaccines, and genetic improvement, has gained impetus in recent years (Hill et al., 2016). Whilst a reliable and accurate measure of $\mathrm{CH}_{4}$ emission forms the basis of evaluating all of the aforementioned strategies, they differ in requirements of accuracy and precision as well as the number, frequency and duration of measurement (Hammond et al., 2016). For instance, genetic evaluations require measurements on large numbers of animals under the environmental conditions they are expected to perform (Falconer and Mackay, 1996).

Indirect calorimetry respiration chambers (RC) are the 'gold standard' for $\mathrm{CH}_{4}$ emission meaning $\mathrm{RC}$ are regarded as the most accurate and precise measurement from which different instruments or techniques are benchmarked (Grainger et al., 2007; Hill et al., 2016). The high accuracy and precision of RC have the benefit of detecting relatively small effects of diets and treatments on $\mathrm{CH}_{4}$ production with small numbers of animals (Patra, 2016). However, the cost for using $\mathrm{RC}$ are high and labor intensive, and are prohibitive to obtaining measurements on large numbers of animals (Grainger et al., 2007; Madsen et al., 2010). Furthermore, the effects of confinement within the chamber may alter animal behaviour and are not necessarily representative of all production systems like extensive grazing systems (Storm et al., 2012), although promising developments have led to reductions in costs and reduced stress due to confinement (Hellwing et al., 2012). Thus the merit of genetic selection under RC conditions and the expectation of reduced $\mathrm{CH}_{4}$ emissions under environmental conditions in which animals are expected to perform, have been called into question (Lassen and Løvendahl, 2016).

A method that has proven well suited to obtaining large numbers of records on individual animals under commercial conditions is the high-throughput, cost effective, and non-invasive 'sniffers' installed in the feed bin of automated milking stations (AMS) or concentrate feeders (Garnsworthy et al., 2012; Lassen et al., 2012; Negussie et al., 2016). The non-invasiveness is achieved by limiting the animal-to-instrument interface, so that the animal is not aware it is being measured and measurement does not disrupt farm activities. The disadvantages of this are a loss of precision due to variable barn gas dynamics and added noise if head movement of the cow and background barn gas levels are not accounted for (Huhtanen et al., 2015; Difford et al., 2016; Wu et al., 2018). Furthermore, sniffer methods record the concentration of gases in the captured breath of the cow during 
milking and are thus a spot measure of gas concentrations and not a full $24 \mathrm{hr}$ mass flux measure (Huhtanen et al., 2015). Rather they utilise the ratio of measures $\mathrm{CH}_{4}$ to carbon dioxide $\left(\mathrm{CO}_{2}\right)$ and predicted $\mathrm{CO}_{2}$ as a tracer gas to approximate $\mathrm{CH} 4$ production in litres per day (Madsen et al., 2010).

New methods which are cheaper, faster or less invasive are continually under development and are of value in situations where the gold standard proves expensive or prohibitive to recording on large numbers of animals. From the genetic evaluation perspective a new method can replace a gold standard method when their genetic correlation exceeds 0.80 (Robertson, 1959). Furthermore, if the genetic correlation is moderate to high and the new method is heritable, it can serve as an indicator trait (Negussie et al., 2017). However, the number of related animals with simultaneous measurements by both methods required to accurately estimate genetic correlations with meaningful standard errors, numbers in the order of thousands of animals (Visscher, 1998). Should measurements with both methods be made on different animals or animals at different points in time the number of animals required to accurate estimate genetic correlations will be far higher (Bijma and Bastiaansen, 2014). In the case of $\mathrm{CH}_{4}$ emission, the $\mathrm{RC}$ constitute a separate environment as most other methods cannot be recorded simultaneously within the $\mathrm{RC}$ and remain representative. Genetic correlations remain elusive, despite calls for international collaborations and the need for genetic correlations between different methods of recording methane emission in dairy cattle (Pickering et al., 2013). It is of interest to researchers and stakeholders to determine the potential difference between methods in ranking of animals prior to the investment in thousands of records using both methods, particularly when the gold standard is expensive and cost limiting. To this end, estimating the repeatability of each method and the individual level correlations between methods is of value. The repeatability of a method serves as the upper threshold for heritability estimates and individual level correlations serve as proxies for genetic correlations, respectively (Falconer and Mackay, 1996; Wolak et al., 2012).

The objective of the present study was to assess the consistency in ranking of dairy cows for $\mathrm{CH}_{4}$ emission phenotypes obtained using sniffers and respiration chambers. 


\subsection{Materials and methods}

\subsubsection{Design and animals}

This experiment was designed to compare $\mathrm{CH}_{4}$ measurements obtained by the non-invasive sniffer method during AMS milking of cows with the open circuit respiration chamber method, which is the intensive and traditional method. The link between the two methods was obtained by having 20 cows (ten Holstein and ten Jersey) measured first by the sniffer method in a semi-commercial setting and then transferred to the respiration chamber facility for repeated measurements during a feeding experiment.

\subsubsection{Sniffer AMS measurement}

Data on $\mathrm{CH}_{4}$ and $\mathrm{CO}_{2}$ gas concentrations from the breath of individual Holstein and Jersey cows recorded during milking at Danish Cattle Research Centre (DCRC, Foulum, Denmark), where sniffer sensors were installed in each of the three AMS (DeLaval International AB, Tumba, Sweden). The sniffer instrumentation is comprised of two sensors, the $\mathrm{CH}_{4}$ sensor (Guardian NG, Edinburgh Instruments Ltd, Livingston, UK) and the $\mathrm{CO}_{2}$ sensor (Gascard, Edinburgh Instruments Ltd, Livingston, UK).The equipment installation, technical specifications, and calibration procedures for the sensors are described elsewhere (Difford et al., 2016). The DCRC barn is a free-stall housing system with individual cubicles and two Holstein and one Jersey management groups, each with an AMS. Cows were offered TMR with an approximate forage to concentrate ratio of (70:30) ad libitum in individualized feeding troughs (RIC-system, Insentec, Marknesse, The Netherlands). Cows were provided up to $3 \mathrm{~kg}$ of concentrate per day (Table 3.1) within the feed bin of the AMS, based on levels of production and thus differences in the forage to concentrate ratio between cows is to be expected. Cows had free access to AMS and presented on average $2.4 \pm 0.86$ visits/d (mean $\pm S D$ ) during the period of measurement. Data on live weight is recorded 10 times every second during AMS milking and the processed as described in (Bossen et al., 2009). Milk production from the AMS and fat, protein and lactose percentage estimated from $48 \mathrm{hr}$ periods each week (Løvendahl and Bjerring, 2006). The estimated milk components were used to correct milk production for fat, protein, and lactose content (ECM) (Sjaunja et al., 1991).

Gas concentrations measured in the on-farm AMS was aligned and merged with the entrance and exit time for each cow visit to the AMS. Data was omitted when the cow's head was predicted to be outside the feed bin using the algorithm described in Difford et al. (2016). The $\mathrm{CH}_{4}$ and $\mathrm{CO}_{2}$ gas concentrations for the 
morning cleaning cycle, when the AMS is empty of any cow, were taken as the ambient barn concentrations for each day, and deducted from the means of each cow visit to obtain background corrected gas concentrations. The starting time for each visit in the AMS was converted to $24 \mathrm{~h}$ angular radians for further modelling of diurnal variation in a Fourier series approach (Lassen et al., 2012). The following model was used on all available DCRC data, within AMS to obtain daily visits corrected for sensor drift, daily variation, and time of day:

$$
y_{i j k l m}=\mu+d_{i}+b_{j}+\sum 3 k=1(f 1 k \sin \theta+f 2 k \cos \theta)+C_{l}+e_{i j k l m}
$$

where $y_{i j k l m}$ is the natural logarithm of background corrected AMS visit means of $\mathrm{CH}_{4}$ and $\mathrm{CO}_{2} ; d_{i}$ is the fixed effect of test day $i(i=23 \mathrm{~d})$; bj is the fixed effect of the first full day after each calibration $j(j=3) ; f 1 k$ and $f 2 k$ are the fixed regression coefficients of Fourier series linear covariates of the time of day of measurement, modelled as harmonic pairs. The time of day of visit expressed as $24 \mathrm{~h}$ angular radians is denoted by $\vartheta$. Term $C_{1}$ is the random effect parameter for each cow $C_{1} \sim N D$ $\left(0, l \sigma^{2} c\right)$, and $e_{i j k l m}$ is the random residuals $\sim N D\left(0, I \sigma^{2} e\right)$. In order to correct daily AMS visit means, the random residuals for each visit are combined with random cow solutions, intercept, calibration day, and the regression coefficients $f 1 k$ and $f 2 k$ multiplied by the angular radian corresponding to 12:00:00 a.m. Further, the $\mathrm{CH}_{4}$ concentration in parts per million and $\mathrm{CO}_{2}$ in ppm as the average per week of lactation, was obtained by taking the corrected means of visits weighted by the number of seconds for each visit. The average weekly breath concentrations on $\mathrm{CH}_{4}$ and $\mathrm{CO}_{2}$ were natural log transformed, here after defined as $\mathrm{CH}_{4} \_\mathrm{C}$ and $\mathrm{CO}_{2}$ C and combined with the weekly performance data from DCRC for ECM (ECM_C), LW $\left(L W \_C\right)$, and gestation length (GL). The average daily $\mathrm{CH}_{4}$ production per week of lactation ( $\mathrm{CH} 4$ _P ; $\mathrm{LCH} 4 / \mathrm{d}$ ) was calculated using the ratio of $\mathrm{CH}_{4}$ C $\mathrm{C}$ to $\mathrm{CO} 2$ _ $\mathrm{C}$ and the equation for $\mathrm{CO}_{2}$ production from heat production units utilizes ECM_C, LW_C, and $\mathrm{GL}$ (CIGR, 2002) and the conversion from heat production to $\mathrm{CO}_{2}$ to obtain predicted $\mathrm{CO}_{2}$ production (CO2_P; L CO2/d) (Pedersen et al., 2008) as suggested by Madsen et al. (2010). Data for the 10 Holstein and 10 Jersey cows from the last three weeks prior to relocation to the facilities with the $\mathrm{RC}$ was retained for further analysis together with $\mathrm{RC}$ records.

\subsubsection{Respiration chamber measurements}

The 10 lactating Holstein cows and 10 lactating Jersey cows were entered into a trial which contained two dietary treatments, a control and a high concentrate diet with respective forage to concentrate ratios of $(68: 32)$ and $(39: 61)$ in a cross- 
over design with back-cross (Olijhoek et al., 2018). The trial was divided into three periods with blocking consisting of four cows per block (five blocks in total per period) with the same cows in each block over periods. Each cow was recorded for duration of $3 \mathrm{~d}$ in period 1 and $2 \mathrm{~d}$ in periods 2 and 3. Methane and $\mathrm{CO} 2$ production in the $\mathrm{RC}\left(\mathrm{CH} 4\right.$ _RC and $\left.\mathrm{CO} 2 \_\mathrm{RC}\right)$ was calculated from the product of the total flow of outgoing air at standard temperature and pressure, and the difference between the gas concentrations in the outgoing air and the gas concentrations in the incoming air from the barn (background). Methane and $\mathrm{CO} 2$ concentration readings from when the chambers were opened twice daily for milking were omitted before calculating the average $\mathrm{CH} 4$ and $\mathrm{CO} 2$ production for each cow, during each period. The average LW and ECM from the RC visits ( $L W \_R C$ and ECM_RC) was retained for further comparisons. The records from these cows were retained for comparison with sniffer measures recorded at DCRC for the same 20 cows as in the RC.

\subsubsection{Statistical Analysis}

Pairwise bivariate animal repeatability models were performed to estimate the variance components and control for fixed effects for the RC traits and the onfarm traits. All analyses were performed using DMU version 6 (Madsen and Jensen, 2014). The model for the RC traits was as follows:

$$
\mathrm{Y}_{\mathrm{ijk} k m n}=\mu+B_{i}+P_{j}+L_{k}+D_{l}+C_{m}+e_{i j k l m n}
$$

Where $y_{i j k l m n}$ is the trait of interest (CH4_RC, CO2_RC, LW_RC and ECM_RC), $\mu$ is the intercept, $B$ is the $i^{\prime}$ th breed $\left(I=2\right.$ levels), $P$ is the $j^{\prime}$ th period effect $(j=3$ levels), $L$ is the $k^{\prime}$ th lactation number ( $k=3$ levels), $D$ is the I'th effect of diet $(I=2$ levels), $C_{m}$ is the random effect of the $m^{\prime}$ th $\operatorname{cow} N\left(0, \sigma^{2} c\right)$ and $e$ is the random residual $\mathrm{N}\left(0, \mathrm{l} \sigma^{2} \mathrm{e}\right)$.

The model for the on-farm traits was as follows:

$$
y_{i j k l m}=\mu+W_{i}+B R_{j}+L_{k}+C_{l}+e_{i j k l m}
$$

Where $\mathrm{y}_{\mathrm{ijk}} \mathrm{m}$ is the trait of interest $\left(\mathrm{CH} 4 \mathrm{P}, \mathrm{CO} 2 \_\mathrm{P}, \mathrm{CH} 4 \_\mathrm{C}, \mathrm{CO} 2 \_\mathrm{C}, \mathrm{LW} \_\mathrm{C}\right.$ and ECM_C), $\mu$ is the intercept, $W$ is the i'th week of lactation ( $=2$ levels), BR is the j'th breed nested within AMS ( $j=3$ levels), $L$ is the $k^{\prime}$ th lactation number effect $(k=3$ levels), $\mathrm{Cl}$ is the random effect of the l'th cow $\mathrm{N}\left(0, \mathrm{C} \sigma^{2} \mathrm{c}\right)$ and $\mathrm{e}$ is the random residual $\mathrm{N}\left(0, \mathrm{l} \sigma^{2} \mathrm{e}\right)$.

For all pairwise comparisons between RC and on-farm traits it was necessary to restrict residual covariance to zero as cows were recorded in different environments. Repeatability estimates $(t)$ were obtained from the variance components by using the equation (4):

$$
t=\frac{\sigma_{c}^{2}}{\left(\sigma_{c}^{2}+\sigma_{e}^{2}\right)}
$$


Individual level correlations $(r l)$, were computed as the correlation between random cow effects using variance components as shown in equation 4 :

$$
r I=\frac{\sigma^{2} c 1, c 2}{\sqrt{\sigma^{2} c 1} \cdot \sqrt{\sigma^{2} c 2}}
$$

The standard errors of the individual level correlations and repeatability estimates where derived using Taylor series approximations.

\subsection{Results and discussion}

The descriptive statistics for on-farm phenotypes and RC phenotypes can be found in Table 3.1. The $\mathrm{CH} 4$ and $\mathrm{CO} 2$ phenotypes followed a similar trend where the predicted mass flux phenotypes $\mathrm{CH} 4$ _P and CO2_P were closer to that of RC mass flux phenotypes $\mathrm{CH} 4 \_\mathrm{RC}$ and $\mathrm{CO} 2$ _RC but with lower means, higher variability and consequently higher coefficients of variation (CV). The breath concentration phenotypes were then further from the means of the RC and predicted mass flux phenotypes with lower means and higher variability and $\mathrm{CV}$. All $\mathrm{CH}_{4}$ and $\mathrm{CO}_{2}$ phenotypes where moderately to highly repeatable ranging from $\mathrm{t}=0.53$ for $\mathrm{CH} 4 \_\mathrm{C}$ to $t=0.87$ for $\mathrm{CO}_{2}$ P . Live weight and ECM were retained as control variables to ensure that the RC environment was not considerably different from that of the onfarm environment for these production traits. The means, SD and CV for LW and ECM were compared across environments with similar descriptive statistics and repeatability estimates for example LW_C and LW_RC had similar means 568.2 vs $564.5 \mathrm{~kg}$ and repeatability $\mathrm{t}=0.93$ and $\mathrm{t}=0.98$, respectively. Recognizing that in the case of the on-farm phenotypes, they are an average of many measurements from the AMS over a full week of lactation whereas RC phenotypes are the average of measurements over a $2-3 \mathrm{~d}$ period in the RC.

The individual level correlations between on-farm phenotypes and RC phenotypes are reported in Table 3.2. For the control phenotypes, ECM and LW the individual level correlations $\left(r_{1}\right)$ between on-farm AMS and RC were close to unity $0.86 \pm 0.15$ and $0.92 \pm 0.04$ respectively. These results indicate very similar ranking of cows across environments and that the effect of confinement within the RC was likely small. Many authors have reported that confinement within RC alters behavior and can induce stress resulting in a drop in feed intake (Beauchemin and McGinn, 2006; Llonch et al., 2016). However, the RC in the present study were constructed from transparent polycarbonate to reduce costs and increase cow welfare, as supported by a study describing that these RC provoked no drop in DMI, when comparing before and during measurement in the RC (Hellwing et al., 2012). 
Table 3.1. Descriptive statistics for on farm measurements and respiration chamber measurements.

\begin{tabular}{|c|c|c|c|c|c|}
\hline \multicolumn{6}{|l|}{ On farm ${ }^{2}$} \\
\hline CH4_P & $L / d$ & 573 & 73.9 & 12.9 & $0.58 \pm 0.11$ \\
\hline $\mathrm{CO} 2 \mathrm{P}$ & $L / d$ & 6771 & 578.7 & 8.5 & $0.87 \pm 0.11$ \\
\hline $\mathrm{CH} 4$ _C & ppm & 410 & 137.0 & 33.4 & $0.53 \pm 0.11$ \\
\hline $\mathrm{CO} 2 \_\mathrm{C}$ & ppm & 5746 & 1791.7 & 31.2 & $0.56 \pm 0.12$ \\
\hline $\mathrm{CH} 4 / \mathrm{CO} 2 \_\mathrm{C}$ & $\mathrm{ppm} / \mathrm{ppm}$ & 0.071 & 0.009 & 12.7 & $0.38 \pm 0.13$ \\
\hline ECM_C & $\mathrm{Kg} / \mathrm{d}$ & 38.1 & 5.93 & 18.1 & $0.71 \pm 0.08$ \\
\hline LW_C & $\mathrm{Kg}$ & 568.2 & 57.3 & 10.1 & $0.93 \pm 0.02$ \\
\hline DMI_C & $\mathrm{Kg} / \mathrm{d}$ & 22.2 & 4.9 & 21.5 & $0.73 \pm 0.07$ \\
\hline \multicolumn{6}{|c|}{ Respiration Chamber ${ }^{3}$} \\
\hline CH4_RC & $L / d$ & 521 & 56 & 10.7 & $0.61 \pm 0.12$ \\
\hline $\mathrm{CO} 2 \_\mathrm{RC}$ & $L / d$ & 6538 & 702.3 & 10.7 & $0.72 \pm 0.10$ \\
\hline $\mathrm{CH} 4 / \mathrm{CO}_{2}$ RC & $L / L$ & 0.081 & 0.006 & 7.7 & $0.57 \pm 0.14$ \\
\hline ECM_RC & $\mathrm{Kg} / \mathrm{d}$ & 28.3 & 5.6 & 19.8 & $0.65 \pm 0.12$ \\
\hline LW_RC & $\mathrm{Kg}$ & 564.5 & 62.3 & 11.0 & $0.98 \pm 0.01$ \\
\hline
\end{tabular}

$\mathrm{CH} 4 \mathrm{P}=$ predicted methane production; $\mathrm{CO}_{-} \mathrm{P}=$ predicted carbon dioxide production; $\mathrm{CH} 4 \_\mathrm{C}=$ methane breath concentration; $\mathrm{CO}_{2} \mathrm{C}=$ carbon dioxide breath concentration; $\mathrm{CH} 4 / \mathrm{CO}_{2} \mathrm{C}=$ ratio of methane to carbon dioxide breath concentration; $\mathrm{ECM} \_\mathrm{C}=$ Energy corrected milk yield; $\mathrm{LW} \_\mathrm{C}=$ live weight; $\mathrm{DMI} \mathrm{C}=$ dry matter intake. ${ }^{3}$ Respiration chamber phenotypes: $\mathrm{CH}_{-}$RC $=$methane production; $\mathrm{CO}_{-} \mathrm{RC}=$ carbon dioxide production; $\mathrm{CH} 4 / \mathrm{CO}_{-} \mathrm{RC}=$ ratio of methane to carbon dioxide production; $E C M \_R C=$ energy corrected milk yield; $L W \_R C=$ live weight. 
Table 3.2 Individual level correlations between on farm phenotypes and respiration chamber phenotypes

\begin{tabular}{lccccc}
\hline \multicolumn{7}{c}{ Respiration chamber $^{2}$} \\
\hline On farm & CH4_RC & CO2_RC & CH4/CO2_RC & ECM_RC & LW_RC \\
\hline CH4_P & $0.77 \pm 0.18$ & $0.63 \pm 0.10$ & $0.70 \pm 0.24$ & $0.68 \pm 0.21$ & $-0.09 \pm 0.29$ \\
CO2_P & $0.74 \pm 0.13$ & $0.79 \pm 0.14$ & $0.41 \pm 0.29$ & $0.58 \pm 0.22$ & $0.20 \pm 0.27$ \\
CH4_C & $0.75 \pm 0.20$ & $0.80 \pm 0.16$ & $0.03 \pm 0.39$ & $0.21 \pm 0.35$ & $0.60 \pm 0.22$ \\
CO2_C & $0.62 \pm 0.24$ & $0.76 \pm 0.18$ & $-0.35 \pm 0.38$ & $0.06 \pm 0.40$ & $0.69 \pm 0.18$ \\
CH4/CO2_C & $0.60 \pm 0.27$ & $0.29 \pm 0.37$ & $0.83 \pm 0.23$ & $0.68 \pm 0.23$ & $-0.66 \pm 0.24$ \\
ECM_C & $0.66 \pm 0.20$ & $0.54 \pm 0.23$ & $0.52 \pm 0.26$ & $0.86 \pm 0.15$ & $-0.14 \pm 0.27$ \\
LW_C & $0.54 \pm 0.22$ & $0.68 \pm 0.16$ & $-0.32 \pm 0.33$ & $-0.24 \pm 0.28$ & $0.92 \pm 0.04$ \\
DMI_C & $0.70 \pm 0.17$ & $0.64 \pm 0.18$ & $0.18 \pm 0.33$ & $0.33 \pm 0.26$ & $0.39 \pm 0.22$ \\
\hline
\end{tabular}

${ }^{1}$ On farm phenotypes: $\mathrm{CH} 4 \_\mathrm{P}=$ predicted methane production; $\mathrm{CO} 2 \_\mathrm{P}=$ predicted carbon dioxide production; $\mathrm{CH} 4 \_\mathrm{C}=$ methane breath concentration; $\mathrm{CO}_{-} \mathrm{C}=$ carbon dioxide breath concentration; $\mathrm{CH} 4 / \mathrm{CO} 2$ C $=$ ratio of methane to carbon dioxide breath concentration; ECM_C = Energy corrected milk yield; LW_C = live weight; DMI_C = dry matter intake. ${ }^{2}$ Respiration chamber phenotypes: $\mathrm{CH} 4$ RC = methane production; $\mathrm{CO} 2 \_\mathrm{RC}=$ carbon dioxide production; $\mathrm{CH} 4 / \mathrm{CO} 2 \_\mathrm{RC}=$ ratio of methane to carbon dioxide production; $E C M \_R C=$ energy corrected milk yield; $L W \_R C=$ live weight. 
The predicted mass flux phenotype $\mathrm{CH} 4$ _P showed the highest $r_{1}$ of any onfarm phenotype with $\mathrm{CH} 4$ RC $0.77 \pm 0.18$ which approaches the threshold of 0.80 for no significant re-ranking, however the standard errors thereof are large. This finding agrees with that of Hellwing et al (2013), who compared $\mathrm{CH}_{4}$ production calculated from the ratio of $\mathrm{CH}_{4}$ to $\mathrm{CO}_{2}$ measured within the $\mathrm{RC}$ and predicted $\mathrm{CO}_{2}$ production to $\mathrm{CH}_{4}$ production measured in the RC for 157 cow measurements in 8 feeding experiments and found an $\mathrm{R}^{2}$ of $55 \%$ which would corresponds to a correlation of 0.74 . The performance of $\mathrm{CH}_{4}$ P $\mathrm{P}$ is reliant on the accuracy of prediction of $\mathrm{CO}_{2}$ P as a tracer gas, the $\mathrm{r}_{1}$ between predicted mass flux ( $\mathrm{CO} 2$ _ $\mathrm{P}$ ) and actual measured $\mathrm{CO}_{2}$ production $\left(\mathrm{CO}_{2} \_\mathrm{RC}\right.$ ) was in a similar order of magnitude $\mathrm{r}_{\mathrm{I}}=$ $0.79 \pm 0.14$ to that of $\mathrm{CH} 4$ _P and $\mathrm{CH} 4$ _RC. A criticism of this $\mathrm{CO}_{2}$ prediction equation is that the metabolizable energy (ME) efficiency and mobilization of body tissues is not taken into account, which runs the risk of over predicting $\mathrm{CO}_{2}$ production of efficient cows (increased LW and ECM at a fixed level of intake) and under predicting $\mathrm{CO}_{2}$ production of inefficient cows (Madsen et al., 2010; Huhtanen et al., 2015). It may be possible to improve the $r_{1}$ between $\mathrm{CH}_{4}$-P and $\mathrm{CH}_{4}$ RC through improving the prediction accuracy of $\mathrm{CO} 2$ _RC by taking into account $\mathrm{ME}$ utilization. For instance Negussie et al (2016) compared CH4_P predicted from the ratio of $\mathrm{CH}_{4}$ to $\mathrm{CO}_{2}$ concentration in the breath of 20 lactating Nordic Red cattle in concentrate feeders and $\mathrm{CO} 2$ _P predicted from metabolizable energy intake and found $\mathrm{CH}_{4}$ _P to have a high concordance correlation coefficient 0.70 and phenotypic correlation 0.80 with CH4_RC.

Since all prediction equations have some level of inherent error and traits used in the prediction of $\mathrm{CO} 2$ _P, e.g. ECM_C, are already in the breeding goal, there is interest in assessing value of directly measured traits like $\mathrm{CH}_{-}$C and $\mathrm{CO} 2$ _C with $\mathrm{RC}$ traits. In this instance $\mathrm{CH} 4$ _C ranked animals comparatively well with $\mathrm{CH} 4$ RC $\mathrm{r}_{1}=$ $0.75 \pm 0.20$ as compared to $\mathrm{CH} 4 \_\mathrm{P}$ and $\mathrm{CH} 4 \_\mathrm{RC} r_{1}=0.77 \pm 0.18$ and exceeded that of both commercial control variables ECM_C, LW_C and DMI_C, which are routinely used to predicted $\mathrm{CH}_{4}$ production (Ramin and Huhtanen, 2013).

A number of authors have labelled breath gas concentration measures as imprecise (Huhtanen et al., 2015; Goopy et al., 2016; Wu et al., 2018) and this may be the case as seen by the lower repeatability estimates of $\mathrm{CH}_{4} \_\mathrm{C}$ and $\mathrm{CO} 2$ _C and the increased CV as compared to other phenotypes. However, the aforementioned studies often compare mass flux $\mathrm{CH}_{4}$ production (g/day) to $\mathrm{CH}_{4}$ breath concentrations using the coefficient of determination $\left(R^{2}\right)$ with the expectation that a deviation of $R^{2}$ from unity (1.0) indicates imprecision. However, the $R^{2}$ metric reflects a combination of between cow variation and residual error (imprecision), recognizing that $\mathrm{CH}_{4} \_\mathrm{C}$ is a separate, by likely correlated trait deviations of $\mathrm{R}^{2}$ from 
1.0 are to be expected regardless of imprecision. In the present study, we made use of individual level correlations which have been corrected for non-genetic effects which can inflate between subject variability (i.e. parity, diet, lactation stage, breed) and thus phenotypic correlations. Furthermore, repeated measures per cow allows for partitioning and removal of residual variance (imprecision) which can bias phenotypic correlations downwards (Adolph and Hardin, 2007; Dingemanse and Dochtermann, 2013). Thus individual level correlations are one-step closer to genetic correlations as compared to phenotypic correlations and the coefficient of determination and are not attenuated by imprecision (Bakdash and Marusich, 2017).

\subsection{Conclusions}

Methane emission traits derived from breath gas measurements during milking correlated the highest with methane production in respiration chambers, exceeding that of live weight, energy corrected milk yield and dry matter intake. However, breath gas phenotypes did not exceed a correlation of 0.80 with $\mathrm{CH} 4$ production in the RC and thus have potential to serve as large-scale indicator traits of $\mathrm{CH} 4$ production. Whilst individual level correlations can serve as a proxy for genetic correlations, genetic correlations between RC phenotypes and breath gas phenotypes are still needed for effective use in genetic selection indices. Given the difficulties in acquiring suitably large numbers of cows in RC, the most feasible current way to achieve this is through international collaborations and incorporation of genomic information.

\section{References}

Adolph, S.C., and J.S. Hardin. 2007. Estimating phenotypic correlations: Correcting for bias due to intraindividual variability. Funct. Ecol. 21:178-184. doi:10.1111/j.1365-2435.2006.01209.x.

Bakdash, J.Z., and L.R. Marusich. 2017. Repeated measures correlation. Front. Psychol. 8:1-13. doi:10.3389/fpsyg.2017.00456.

Beauchemin, K.A., and S.M. McGinn. 2006. Methane emission from beef cattle: effects of fumaric acid, essential oil and canola oil. J. Anim. Sci. 84:1489-1496. doi:10.2527/2006.8461489x.

Bijma, P., and J.W.M. Bastiaansen. 2014. Standard error of the genetic correlation: how much data do we need to estimate a purebred-crossbred genetic correlation?. Genet. Sel. Evol. 46:79. doi:10.1186/s12711-014-0079-z. 
Bossen, D., M.R. Weisbjerg, L. Munksgaard, and S. Højsgaard. 2009. Allocation of feed based on individual dairy cow live weight changes. I: Feed intake and live weight changes during lactation. Livest. Sci. 126:252-272. doi:10.1016/j.livsci.2009.07.010.

CIGR. 2002. 4th Report of Working Group on Climatization of Animal Houses: Heat and Moisture Production at Animal and House Levels. S. Pedersen and K. Sällvik, ed. Research Centre Bygholm. DIAS, Horsens, Denmark.

Difford, G.F., J. Lassen, and P. Løvendahl. 2016. Interchangeability between methane measurements in dairy cows assessed by comparing precision and agreement of two non-invasive infrared methods. Comput. Electron. Agric. 124:220-226. doi:10.1016/j.compag.2016.04.010.

Dingemanse, N.J., and N.A. Dochtermann. 2013. Quantifying individual variation in behaviour: mixed- effect modelling approaches. J. Anim. Ecol. 39-54. doi:10.1111/1365-2656.12013.

Falconer, D., and T. Mackay. 1996. Introduction to quantitative genetics (4th edn). Genet.

Garnsworthy, P.C., J. Craigon, J.H. Hernandez-Medrano, and N. Saunders. 2012. Onfarm methane measurements during milking correlate with total methane production by individual dairy cows. J. Dairy Sci. 95:3166-80. doi:10.3168/jds.2011-4605.

Grainger, C., T. Clarke, S.M. McGinn, M.J. Auldist, K. a Beauchemin, M.C. Hannah, G.C. Waghorn, H. Clark, and R.J. Eckard. 2007. Methane emissions from dairy cows measured using the sulfur hexafluoride (SF6) tracer and chamber techniques. J. Dairy Sci. 90:2755-2766. doi:10.3168/jds.2006-697.

Hammond, K.J., L.A. Crompton, A. Bannink, J. Dijkstra, D.R. Yáñez-Ruiz, P. O’Kiely, E. Kebreab, M.A. Eugenè, Z. Yu, K.J. Shingfield, A. Schwarm, A.N. Hristov, and C.K. Reynolds. 2016. Review of current in vivo measurement techniques for quantifying enteric methane emission from ruminants. Anim. Feed Sci. Technol. 219:13-30. doi:10.1016/j.anifeedsci.2016.05.018.

Hellwing, A.L.F., P. Lund, J. Madsen, and M.R. Weisbjerg. 2013. Comparison of enteric methane production predicted from the $\mathrm{CH} 4 / \mathrm{CO} 2$ ratio and measured in respiration chambers. Adv. Anim. Biosci. 4:6077-6085.

Hellwing, A.L.F., P. Lund, M.R. Weisbjerg, M. Brask, and T. Hvelplund. 2012. Technical note: test of a low-cost and animal-friendly system for measuring methane emissions from dairy cows. J. Dairy Sci. 95:6077-85. doi:10.3168/jds.2012-5505.

Hill, J., C. McSweeney, A.-D.G. Wright, G. Bishop-Hurley, and K. Kalantar-zadeh. 2016. Measuring methane production from ruminants. Trends Biotechnol. 34:26-35. doi:10.1016/j.tibtech.2015.10.004. 
Huhtanen, P., E.H. Cabezas-Garcia, S. Utsumi, and S. Zimmerman. 2015. Comparison of methods to determine methane emissions from dairy cows in farm conditions. J. Dairy Sci. 98:3394-3409. doi:10.3168/jds.2014-9118.

Lassen, J., and P. Løvendahl. 2016. Heritability estimates for enteric methane emissions from Holstein cattle measured using noninvasive methods. J. Dairy Sci. 99:1959-1967. doi:10.3168/jds.2015-10012.

Lassen, J., P. Løvendahl, and J. Madsen. 2012. Accuracy of noninvasive breath methane measurements using Fourier transform infrared methods on individual cows. J. Dairy Sci. 95:890-8. doi:10.3168/jds.2011-4544.

Llonch, P., S.M. Troy, D. Carol-Anne, S. Miguel, R. John, H.M. J., R. Rainer, and T.S. P. 2016. Changes in feed intake during isolation stress in respiration chambers may impact methane emissions assessment. Anim. Prod. Sci.. doi:https://doi.org/10.1071/AN15563.

Løvendahl, P., and M. a Bjerring. 2006. Detection of carryover in automated milk sampling equipment.. J. Dairy Sci. 89:3645-3652. doi:10.3168/jds.S00220302(06)72404-3.

Madsen, J., B.S. Bjerg, T. Hvelplund, M.R. Weisbjerg, and P. Lund. 2010. Methane and carbon dioxide ratio in excreted air for quantification of the methane production from ruminants. Livest. Sci. 129:223-227. doi:10.1016/j.livsci.2010.01.001.

Negussie, E., Y. de Haas, F. Dehareng, R.J. Dewhurst, J. Dijkstra, N. Gengler, D.P. Morgavi, H. Soyeurt, S. van Gastelen, T. Yan, and F. Biscarini. 2017. Invited review: Large-scale indirect measurements for enteric methane emissions in dairy cattle: A review of proxies and their potential for use in management and breeding decisions. J. Dairy Sci. 100:2433-2453. doi:10.3168/jds.2016-12030.

Negussie, E., J. Lehtinen, P. Mäntysaari, A.R. Bayat, A.-E. Liinamo, E.A. Mäntysaari, and M.H. Lidauer. 2016. Non-invasive individual methane measurement in dairy cows. Animal 4:1-10. doi:10.1017/S1751731116002718.

Patra, A.K. 2016. Recent advances in measurement and dietary mitigation of enteric methane emissions in ruminants. Front. Vet. Sci. 3:1-17. doi:10.3389/fvets.2016.00039.

Pedersen, S., V. Blanes-Vidal, H. Joergensen, A. Chwalibog, A. Haeussermann, M.J.W. Heetkamp, and A.J.A. Aarnink. 2008. Carbon Dioxide Production in Animal Houses: A literature review. Agric. Eng. Int. CIGR Ejournal X:1-19. doi:10.1017/CBO9781107415324.004.

Pickering, A.N.K., Y. De Haas, J. Basarab, K. Cammack, B. Hayes, R.S. Hegarty, J. Lassen, J.C. McEwan, S. Miller, S. Pinares-Patino, G. Shackell, P. Vercoe, and V.H. Oddy. 2013. Consensus methods for breeding low methane emitting animals. 
Ramin, M., and P. Huhtanen. 2013. Development of equations for predicting methane emissions from ruminants. J. Dairy Sci. 96:2476-2493. doi:10.3168/jds.2012-6095.

Sjaunja, L.O., L. Baevre, L. Junkkarinen, J. Pedersen, and J. Setala. 1991. A Nordic Proposal for an Energy Corrected Milk (ECM) Formula EAAP Publication 50: Performance Recording of Animals. State of the Art 1990, Centre for Agricultural Publishing and Documentation (PUDOC), Wageningen, the Netherlands.

Visscher, P.M. 1998. On the sampling variance of intraclass correlations and genetic correlations. Genetics 149:1605-1614.

Wolak, M.E., D.J. Fairbairn, and Y.R. Paulsen. 2012. Guidelines for estimating repeatability. Methods Ecol. Evol. 3:129-137. doi:10.1111/j.2041210X.2011.00125.x.

Wu, L., P.W.G.G. Koerkamp, and N. Ogink. 2018. Uncertainty assessment of the breath methane concentration method to determine methane production of dairy cows. J. Dairy Sci. 101:1554-1564. doi:10.3168/jds.2017-12710. 



\section{Chapter 4}

\section{Can greenhouse gases in breath be used to genetically improve feed efficiency of dairy cows?}

G. F. Difford ${ }^{1,2}$, P. Løvendahl' ${ }^{1}$, R. F. Veerkamp ${ }^{2}$, H. Bovenhuis ${ }^{2}$, M. H. P. W. Visker $^{2}$, J. Lassen ${ }^{3}$, Y. de Haas ${ }^{2}$

1 Department of Molecular Biology and Genetics, Faculty of Science and Technology, Aarhus University, PO Box 50, DK-8830 Tjele, Denmark; ${ }^{2}$ Animal Breeding and Genomics Centre, Wageningen University, P.O. Box 338, $6700 \mathrm{AH}$ Wageningen, The Netherlands; ${ }^{3}$ Viking Genetics, Ebeltoftvej 16, Assentoft, 8960 Randers, Denmark 



\section{Abstract}

There is considerable interest in improving feed utilization of dairy cattle whilst limiting losses to the environment (i.e. greenhouse gases (GHG)). In order to breed for feed efficient or climate friendly cattle, it is first necessary to obtain accurate estimates of genetic parameters and correlations of feed intake, greenhouse gases and production traits. Reducing dry matter take (DMI) whilst maintaining production has high economic value to farmers, but DMI is costly to record and thus limited to small research or nucleus herds. Conversely, enteric methane $\left(\mathrm{CH}_{4}\right)$ currently has no economic value, and is also costly to record and is limited to small experimental trials. However, breath gas concentrations of methane $(\mathbf{C H} 4 \mathbf{c})$ and carbon dioxide (CO2c) are relatively cheap and have a high throughput under commercial conditions by installing sniffers into automated milking stations. The objective of this study was to combine DMI records from Denmark (DNK) and The Netherlands (NLD) and assess the genetic correlations with body weight (BW), fat and protein corrected milk yield (FPCM) and GHG related traits: $\mathrm{CH} 4 \mathrm{C}$ and $\mathrm{CO} 2 \mathrm{c}$. Secondly, to assess the genetic potential for reducing DMI whilst maintaining FPCM and BW, and the added benefits of using $\mathrm{CH} 4 \mathrm{c}$ and $\mathrm{CO} 2 \mathrm{c}$ as indicators. Feed intake data was available on 812 primiparous cows in DNK and 2112 in NLD. Furthermore, $\mathrm{CH} 4 \mathrm{c}$ and $\mathrm{CO} 2 \mathrm{c}$ records were available on 478 primiparous cows in DNK and 660 in NLD. Genetic parameters were estimated using full trait animal models for DNK, NLD and combined from both countries. A restricted selection index for reducing DMI whilst maintaining FPCM and BW (genetic residual feed intake, gRFI) was heritable in and over both countries (DNK $=0.15, \mathrm{NLD}=0.17$, Combined $=0.14$ ), and genetically correlated to DMI (DNK =0.21, $\mathrm{NLD}=0.74$, Combined $=0.64$ ), but uncorrelated to FPCM and BW. The greenhouse gas related traits were heritable e.g. $\mathrm{CH} 4 \mathrm{c}(\mathrm{DNK}=0.26, \mathrm{NLD}=0.16$, Combined $=0.22$ ), and moderately genetically correlated to DMI (DNK $=0.58, \mathrm{NLD}=0.29$, Combined $=$ 0.41 ). The relatively cheap GHG related traits showed considerable potential to improve the accuracy of breeding values of the highly valuable breeding goal traits feed intake and feed efficiency.

Key words: Breath concentration, Feed efficiency, Methane, Sniffers 



\subsection{Introduction}

The dairy industry faces major challenges to remain profitable whilst maintaining environmental sustainability (for instance mitigating greenhouse gas emissions like methane $(\mathrm{CH} 4)$ and carbon dioxide ( $\mathrm{CO} 2)$ ). Feed plays a crucial role in economic and environmental performances of dairy production units, as feed constitutes the highest variable cost of production (Hemme et al., 2014). Feed composition affects not only $\mathrm{CH} 4$ emissions at an individual cow level (Hristov et al., 2013), but the entire dairy production chain as well (Møller et al., 2014). The primary income from milk is volatile as milk prices often fail to increase with feed prices (Hemme et al., 2014). A promising way to increase profitability is to reduce feed costs through reducing feed intake and improving or maintaining production in the breeding objective (Veerkamp, 1998; de Haas et al., 2012). In other words, identifying cows that require less feed to give the same levels of production as contemporaries.

However, feed efficiency is not a directly observable trait, rather it is a combination of multiple traits including feed intake and production. Feed efficiency is thus defined as feed intake conditional on a combination of production traits or energy sinks (e.g. fat and protein correct milk (FPCM), body weight (BW), etc.) (Jensen et al., 1992). The most prevalent feed intake trait is dry matter intake (DMI), as this accounts for differences in moisture content of feeds and is the most prevalent across countries (Berry et al., 2014). The recording of DMI is labor intensive, expensive and limited to small research or nucleus herds, resultantly the reliability of sire breeding values are low (de Haas et al., 2012). This could in principle be overcome by including heritable and correlated predictor traits measured on a large scale in commercial and research herds in conjunction with accurate small scale research and contract herds with DMI recording (Berry and Crowley, 2013; Manzanilla-Pech et al., 2016; Wallén et al., 2017).

Identifying the cows that genetically require lower feed intake whilst giving the same levels of production as contemporaries is challenging, as DMI is highly genetically correlated to production traits like FPCM and BW (Manzanilla Pech et al., 2014). Resultantly, selection for decreased DMI is expected to have correlated reductions is FPCM and BW, which would simultaneously decrease feed costs and income from milk production. Feed efficiency traits like feed conversion ratio (FCE = FPCM/DMI) and residual feed intake (RFI), fare no better as both retain genetic correlations with production traits (Manafiazar et al., 2015). Following a restricted selection index approach (Kennedy et al., 1993) defined genetic residual feed intake (gRFI) as DMI genetically independent of FPCM and BW, which overcomes the 
inherent deficiencies of ratio or phenotypic regression residual definitions of feed efficiency (Lu et al., 2015). However, the desirable statistical properties of gRFI can also hinder its uptake, since sufficiently large numbers of records on animals are required to accurately estimate the genetic correlation between DMI, FPCM and BW, which are likely only achievable through international collaborations (Berry et al., 2014). Furthermore, FPCM and BW can no longer serve as large-scale indicators of gRFI outside of their use as indicators of DMI, as they are genetically uncorrelated to gRFI. Given the difficulties in obtaining DMI records on large numbers of cows, there is a need for other easily recorded large scale traits genetically correlated to gRFI that are independent of FPCM and BW.

Studies using the intensive gold standard respiration chambers have shown high phenotypic correlations between mass fluxes of the greenhouse gas traits (GHG), CH4 and CO2 with DMI (Yan et al., 2010). Furthermore, the calorie value of $\mathrm{CH} 4$ has been estimated as $2 \%-12 \%$ of the gross energy intake of the cow (Johnson and Johnson, 1995). This has led to numerous prediction equations employing DMI and feed components to predict $\mathrm{CH} 4$ production (Ellis et al., 2007; Ramin and Huhtanen, 2013), and genetic and genomic parameters for predicted $\mathrm{CH} 4$ emission from DMI or metabolisable energy intake (de Haas et al., 2011; Negussie et al., 2014). Furthermore, predicted methane emission was found to be favorably genetically correlated to phenotypic RFI (de Haas et al., 2011). Thus turning this idea around, GHG traits like $\mathrm{CH} 4$ production could potentially serve as indicator traits for DMI and gRFI. However, respiration chambers (RC) have high capital and labor costs and have mostly proven prohibitive to large scale genetic evaluations, with the largest studies using RC reaching approximately 1000 individuals in growing beef or sheep breeds (Pinares-Patiño et al., 2013; Donoghue et al., 2016). Furthermore, confinement within the RC is known to impact natural animal behavior and can cause a drop in DMI, leading many to question the extrapolation of these results to intensive commercial and grazing systems (Pinares-Patiño and Clark, 2008). Thus, the potential of GHG traits recorded using RC as indicator traits remains limited.

Recently, a cost effective, non-invasive and high through put method of recording methane $(\mathrm{CH} 4 \mathrm{c})$ and carbon dioxide concentrations $(\mathrm{CO} 2 \mathrm{c})$ in the breath of individual cattle under commercial conditions, whilst milking in the automated milking stations (AMS) (Garnsworthy et al., 2012a; Lassen et al., 2012) or concentrate feeders has emerged, collectively known as sniffers (Negussie et al., 2016). Since sniffers record gas concentrations and not mass fluxes, researchers have used scaling factors and calibrations (Garnsworthy et al., 2012b) or predicted $\mathrm{CO} 2$ as a tracer gas to approximate $\mathrm{CH} 4$ mass fluxes (Madsen et al., 2010). These approximations have been shown to be heritable, genetically correlated with FPCM and BW and have good 
concordance with RC (Garnsworthy et al., 2012b; Lassen and Løvendahl, 2016; Negussie et al., 2016). The direct measures $\mathrm{CH} 4 \mathrm{c}$ and $\mathrm{CO} 2 \mathrm{c}$ have recently been reported as lowly heritable 0.11 and 0.12, respectively (van Engelen et al., 2018). However, the genetic correlations of $\mathrm{CH} 4 \mathrm{c}$ and $\mathrm{CO} 2 \mathrm{c}$ with feed intake and production traits are currently not known and their potential as indicator traits for DMI or gRFI is under-exploited.

The aims of this study were to estimate genetic parameters for feed intake related traits and greenhouse gas related traits in primiparous Holsteins in Denmark (DNK) and The Netherlands (NLD). Secondly, assess the use of breath concentration GHG traits as large-scale indicator traits for improving the accuracy of breeding values for DMI and gRFI.

\subsection{Materials and Methods}

\subsubsection{Design and animals}

Data on individual DMI, BW and FPCM as well as $\mathrm{CH} 4 \mathrm{C}$ and $\mathrm{CO} 2 \mathrm{c}$ was collected repeatedly over lactation in primiparous Danish Holstein and Dutch Holstein Friesian cows. Both countries have recorded DMI, BW and FPCM in indoor research herds over the last few decades, with numerous nutritional trials of various total mixed ration (TMR) feeds and expressed these as weekly averages for genetic evaluations. More recently, both countries have installed non-invasive sniffers in AMS at the research stations and in commercial herds for the repeated recording of $\mathrm{CH} 4 \mathrm{c}$ and $\mathrm{CO} 2 \mathrm{c}$, expressed as weekly averages. The commercial herds were included to improve the representativeness of genetic parameters estimated and convergence of multitrait animal models as these herds had $\mathrm{CH} 4 \mathrm{c}, \mathrm{CO} 2 \mathrm{c}, \mathrm{FPCM}$ and BW. The data collection, editing and analysis is presented below.

\subsubsection{Data Collection and Editing: Feed intake traits}

Denmark. A total of 29,084 weekly averaged records for DMI, BW and milk yield (MY) were available on 812 primiparous Danish Holstein cows which calved from 1995 - 2015. Cows that calved between 1995 to 2000 were located at Ammitsbøl Skovgaard research herd (Skovgaard, Vejle, Denmark), from November 2001 until present the cows were relocated to the Danish Cattle Research Center (DCRC; Foulum, Denmark), as previously reported (Li et al., 2017). The Skovgaard barn was a tie stall system, with milking conducted twice daily and proportional samples drawn to estimate milk fat, protein and lactose content. Body weight measurements taken once a week until 3 months after calving at which point they were weighed fortnightly. Cows were fed manually $3-5$ times a day to allow for $5 \%$ 
refusal and individual refusals recorded to determine feed intake, weekly samples of feed were taken to estimate dry matter content of the rations. The DCRC barn is a loose housing system where cows have free access to ad libitum feed in individual automated feed bins (RIC system, Insentec B.V., Marknesse, the Netherlands). Cows also had access to automatic milking stations (AMS; DeLaval AB, Tumba, Sweden) where they were offered up to $3 \mathrm{~kg}$ of concentrate a day within the integral AMS feed bins. The AMS was fitted with a weighing platform (Danvaegt, Hinnerup, Denmark) to record BW at each milking and a device delivering and recording the amounts of concentrates and refusals.

Cows were entered into numerous nutritional trials at DCRC and have remained on a largely unchanged control TMR diet in between trials, which consists of rolled barley, corn silage, grass clover silage, rapeseed meal, and soybean meal. The DM contents of the TMR and concentrates were determined from regular analysis and combined with averaged weekly feed intake to obtain DMI per cow per week of lactation. Although multiple trials calculated, energy contents of specific feed treatments, energy intake was largely unavailable for the majority of cows. The diets within a specific treatment are expected to be the same, whilst dietary differences between treatment levels are expected. Furthermore, the dietary composition of the control diets can be expected to change with the influences of year and seasons on feed ingredients (Nielsen et al., 2003). Thus, an experiment by treatment interaction term was created which corresponds to the experimental trial and specific treatment in the case of nutritional experiments and a year by season variable for the control diet. This method of modelling the changes in ration is consistent with modelling longitudinal intake data in other internal genetic evaluations such as the global dry matter initiative (gDMI) (Berry et al., 2014).

When combining the data from Skovgaard where milking was conducted twice daily and DCRC where milking was voluntary in AMS, the $3 \mathrm{~d}$ moving average approach described by ICAR (2016) was employed. In this approach daily MY is obtained from, the sum of yield over $3 \mathrm{~d}$ divided by milking intervals and multiplied by $24 \mathrm{~h}$. Milk composition was determined from every milking over a consecutive 48 h period each week using CombiFoss (Foss, Hillerød, Denmark) operated by Eurofins (Vejen, Denmark). Composition data from each milking were used to calculate yields of fat and protein which were smoothed by the moving average method to obtain daily yields. The calculated yields were averaged per week to get weekly records on the same time scale as DMI records. The DCRC records for BW, MY and DMI where filtered to remove weekly averages where more than two days records were missing. Cows which had less than 5 weekly records during their first lactation or an age of calving greater than 36 months were omitted. Although many of the experimental 
treatments were carefully blocked and balanced, these trials often included multiparous cows which were not the focus of the present study. Thus, a filter of a minimum of 5 cows per experimental treatment was added to ensure adequate degrees of freedom for effect estimation. The records after editing are summarized in Table 4.1 with datasets DNK1 and DNK2 corresponding to Skovgaard and DCRC, respectively.

The Netherlands. In total 47,356 weekly averaged records for DMI, BW and milk yield (MY) were included in analysis on 2112 primiparous Dutch Holstein cows which calved from 1986 - 2015. The Dutch data was comprised of multiple nutritional experiments conducted at multiple locations in The Netherlands (e.g. Aver Heino; Bosma Zathe, Ureterp; Cranendonck, Soerendonk; 't Gen, Lelystad; Minderhoudhoeve, Swifterbant; Waiboerhoeve Dairy unit 2, 3, Lelystad; Zegveld farm, Zegveld; Hoorn, Lelystad; New Waiboerhoeve, Lelystad; Dairy Campus, Lelystad). Data from these farms has been classified into four datasets (NLD1, NLD2, NLD3 and NLD4) based on previous studies which have described data collection (see Table 4.1) (Veerkamp et al., 2000; Beerda et al., 2007; Zom et al., 2012; van Knegsel et al., 2014). All herds made use of indoor housing and offered TMR that primarily consisted of grass silage, fresh grass, dehydrated grass, corn, corn silage, cereal, concentrates or beet pulp.

Differences in the recording method and frequencies exist between datasets and within datasets through time and will be mentioned briefly. Milking was conducted twice daily for most herds, with the exception of one herd $(n=50)$ where cows were milked three times a day and the AMS herds where milking frequency is based on voluntary milking.

Initially, dry matter intake was recorded manually at 1, 2, 3 or 5 times per week depending on the experiment (Veerkamp et al., 2000; Beerda et al., 2007; Zom et al., 2012). Later, feed intake was recorded using individual automated feed bins (RIC system, Insentec B.V., Marknesse, the Netherlands). Feed was offered to achieve a $10 \%$ refusal rate, with offered feed recorded automatically but refusals recorded manually (Zom et al., 2012). In general, BW was recorded either daily, three times a week using automatic weighing platforms or in the AMS integral automatic weighing platforms. Cows were entered into numerous nutritional trials, where the diets within treatments are expected to be the same but differ between trial treatments. The DM composition of diets was used to calculate DMI, but the specific dietary composition and energy of many diets were not available. Fat and protein contents of milk were estimated at minimum once per week in all datasets. Data editing steps included only retaining cows with a Holstein breed percentage of $75 \%$ 
or greater, minimum of 5 observations per experimental treatment and 5 records per cow and calved no later than 36 months of age.

Fat and protein corrected milk yield was calculated for both Denmark and The Netherlands using a single standardization equation of $4.0 \%$ fat and $3.3 \%$ protein as recommended in $(F A O, 2010)$ using the $\mathrm{FPCM}(\mathrm{kg})=(0.337 *$ milk yield $\mathrm{kg})+$ $(11.6 *$ fat yield kg) + (5.999* protein yield) $(C V B, 2008)$.

\subsubsection{Data Collection and Editing: Greenhouse gas traits}

Denmark. Data on the $\mathrm{CH} 4 \mathrm{C}$ and $\mathrm{CO} 2 \mathrm{c}$ of individual Holsteins cows during milking was available on 267 primiparous cows at DCRC from mid 2013 - November 2016, with simultaneous DMI, FPCM and BW records. The non-dispersive infrared (NDIR) $\mathrm{CH}_{4}$ sensor (Guardian NG, Edinburgh Instruments Ltd, Livingston, UK) and the NDIR $\mathrm{CO}_{2}$ sensor (Gascard, Edinburgh Instruments Ltd, Livingston, UK) were installed in each of the AMS. The equipment installation, technical specifications, and calibration procedures for the sensors are described elsewhere (Difford et al., 2016). The time stamped AMS visit data and breath gas concentration time series on a 1 second basis were merged using a time alignment algorithm (Difford et al., 2016). Gas data from AMS milkings shorter than 300s and marked as incomplete or interrupted by the AMS were removed. A cow head-lifting algorithm was used to filter out gas readings when the cow's head is predicted to be outside of the feed bin (Difford et al., 2016). The ambient barn concentrations of $\mathrm{CH} 4 \mathrm{c}$ and $\mathrm{CO} 2 \mathrm{c}$ were estimated once daily during the morning cleaning cycle of the AMS when the AMS is free of cows and subtracted from the mean $\mathrm{CH} 4 \mathrm{c}$ and $\mathrm{CO} 2 \mathrm{c}$ of each milking for that day.

Greenhouse gas measurements were also taken in two commercial herds in Denmark from November 2015 until March 2016 as part of the REMRUM project. A portable set of four NDIR sensors as above and one portable Fourier transform infrared (FTIR) Gasmet DX-4000 (Gasmet; Gasmet Technologies Oy, Helsinki, Finland), which registers gas concentrations on a $5 \mathrm{~s}$ basis. The use of the FTIR equipment in commercial herds is described elsewhere (Lassen and Løvendahl, 2016). The data from commercial herds was handled the same as the research herd described above. Sensors were installed in AMS (Astronaut A3, Lely Industries, NV, Maassluis, the Netherlands) equipped with weighing platforms. The milk components were taken from the national recording scheme (RYK, Skejby, Denmark) and cow fat and protein corrected milk yield (FPCM) (CVB, 2008; FAO, 2010) was estimated as in the Dutch population.

Data from the research and commercial herds were filtered to only include weekly averages where a maximum of 3 days were missing within each week of 
measurement and each cow had a minimum of 3 weekly measurements (Table 4.1). The effect of contemporary group and AMS are by necessity confounded at DCRC and are thus also confounded with the experiment by treatment interaction described for the feed intake traits. The commercial herds maintained the same diet whilst gases were recorded; a variable of year by season by AMS group nested within herd was used in place of the experiment by treatment term used in the research herds. Similarly, gas traits were filtered to ensure each experiment by treatment interaction term had at least 5 cows and a minimum of 5 weekly records per cow. The dataset from DCRC corresponding to DNK2 and commercial herds corresponding to DNK3 (Table 4.1).

The Netherlands. Data on the $\mathrm{CH} 4 \mathrm{c}$ and $\mathrm{CO} 2 \mathrm{c}$ breath gas concentrations of individual Holstein cows during milking was available on 277 primiparous cows at Dairy Campus Lelystad (NLD4) from October 2013 - November 2016, with simultaneous FPCM and BW records. The grouping of animals at NLD4 is such that the two AMS groups do not have automatic feed bins. Thus cows are tested for $70 \mathrm{~d}$ for DMI and then moved to the AMS groups where gas recording takes place, no simultaneous records for DMI and gases are available in The Netherlands. The FTIR sensor inlet was installed in the integral feed bins of two AMS (Astronaut A3, Lely Industries, NV, Maassluis, the Netherlands), where gases were drawn from each of the AMS on alternating days. The time stamped AMS visit data and breath gas concentration time series on a 5 second basis were merged. The air sampled for the first 20 seconds of each visit was discarded to ensure no carryover of gas readings from the previous cow's milking. Data from milkings that lasted shorter than 120 seconds and data collected after 600 seconds of the start of the milking were excluded. As well as data from milkings marked as error by the AMS were excluded. The ambient barn concentrations of $\mathrm{CH} 4 \mathrm{c}$ and $\mathrm{CO} 2 \mathrm{c}$ were estimated once daily during the morning cleaning cycle of the AMS when the AMS is free of cows and subtracted from the mean $\mathrm{CH} 4 \mathrm{c}$ and $\mathrm{CO} 2 \mathrm{c}$ of each milking for that day. After editing 5904 weekly average records were available on 277 primiparous Holstein cows corresponding to dataset NLD4 (Table 4.1).

Data on the $\mathrm{CH} 4 \mathrm{c}$ and $\mathrm{CO} 2 \mathrm{c}$ on 382 primiparous Dutch Holstein Friesian cows from 11 commercial herds over November 2013 - March 2016 as part of the TiFN project 'Reduced methane emission of dairy cows' (NLD5) (Table 4.1). Four portable NDIR sensors (SenseAir LPL $113 \mathrm{CH}_{4} / \mathrm{CO}_{2}$, Rise Acreo, Stockholm, Sweden) were installed in the integral feed bin of AMS (Lely, Astronaut A4, Lely Industries NV, Maassluis, the Netherlands) which record $\mathrm{CH} 4 \mathrm{c}$ and $\mathrm{CO} 2 \mathrm{c}$ twice per second. The sampling strategies, installation and phenotype calculation has been descried elsewhere (van Engelen et al., 2018). Briefly, the time series data was aligned to the 
AMS data by a function which maximizes the $\mathrm{CH} 4 \mathrm{c}$ and $\mathrm{CO} 2 \mathrm{c}$ during visits and minimizes $\mathrm{CH} 4 \mathrm{c}$ and $\mathrm{CO} 2 \mathrm{c}$ between visits. Visits which failed to exceed 90 seconds in length were excluded. The background concentrations for $\mathrm{CH} 4 \mathrm{c}$ was assumed to be $0 \mathrm{ppm}$ and $\mathrm{CO} 2 \mathrm{c} 400 \mathrm{ppm}$, these values were subtracted from the mean of 10 minimum recordings per visit and subtracted from the mean of the visit to approximate a background corrected $\mathrm{CH} 4 \mathrm{C}$ and $\mathrm{CO} 2 \mathrm{c}$ mean per milking. The $\mathrm{CH} 4 \mathrm{c}$ and $\mathrm{CO} 2 \mathrm{c}$ per milking were combined with the MY per milking. Where possible the mean BW per milking was retained, however the majority of AMS were not equipped with integral weighing platforms so BW was not available from all locations. Records on milk components during the sampling periods for each herd were acquired from the cooperative cattle improvement organization CRV (Arnhem, the Netherlands) to estimate FPCM.

Data from the research and commercial herds were filtered to only include weekly averages where a maximum of 3 days were missing within each week of measurement and each cow had a minimum of 3 weekly measurements (Table 4.1). The effect of contemporary group and AMS were by necessity confounded at Dairy Campus and are thus confounded with the experiment by treatment interaction described for the feed intake traits. The commercial herds maintained the same diet whilst gases were recorded; a variable of year by season by AMS group nested within herd was used in place of the experiment by treatment term used in the research herds. Similarly, gas traits were filtered to ensure each experiment by treatment interaction term had at least 5 cows and a minimum of 5 weekly records per cow (Table 4.1).

\subsubsection{Data Collection and Editing: Pedigrees}

Pedigree information of all animals was traced back to founder generations, by extracting the Danish and Dutch pedigrees from the Nordic Cattle Genetic Evaluation Database (NAV, Skejby, Denmark) and the cooperative cattle improvement organization CRV (Arnhem, the Netherlands). Pedigrees were merged and all aliases in the pedigree were removed through the use of the Interbull identification cross-reference tables and manual curation of the pedigree. Noninformative individuals in the pedigrees were removed with the DMU Trace program (Madsen, 2012). The total pedigree file consisted of 16,592 animals with a DNK pedigree of 9774 animals and NLD pedigree of 8042 animals. A total of 1074 sires were in common between the two pedigrees. 
Table 4.1. Description of available phenotypic records of dry matter intake (DMI), fat and protein corrected milk (FPCM), body weight (BW), methane breath concentration $(\mathrm{CH} 4 \mathrm{c})$ and carbon dioxide breath concentration $(\mathrm{CO} 2 \mathrm{c})$ for first parity Holstein Friesian cows in Denmark and The Netherlands.

\begin{tabular}{|c|c|c|c|c|c|c|c|c|}
\hline \multirow[b]{2}{*}{ Data set } & \multicolumn{3}{|c|}{ Denmark } & \multicolumn{5}{|c|}{ The Netherlands } \\
\hline & DNK1 & DNK2 & DNK3 & NLD1 & NLD2 & NLD3 & NLD4 & NLD5 \\
\hline of & 2 & 24 & 1 & 13 & 1 & 3 & 61 & 1 \\
\hline \multicolumn{9}{|l|}{ experiments } \\
\hline \# of rations & 2 & 112 & 2 & 47 & 27 & 27 & 268 & 10 \\
\hline $\begin{array}{l}\text { \# locations } \\
\text { \# of cows with }{ }^{1} \text { : }\end{array}$ & 1 & 1 & 2 & 1 & 1 & 2 & 9 & 10 \\
\hline DMI & 109 & 703 & 0 & 195 & 491 & 393 & 1,033 & 0 \\
\hline FPCM & 108 & 702 & 267 & 193 & 474 & 362 & 1,183 & 362 \\
\hline BW & 111 & 702 & 267 & 195 & 490 & 361 & 1,217 & 101 \\
\hline $\mathrm{CH} 4 \mathrm{c}$ & 0 & 211 & 267 & 0 & 0 & 0 & 277 & 382 \\
\hline $\mathrm{CO} 2 \mathrm{c}$ & 0 & 211 & 267 & 0 & 0 & 0 & 277 & 382 \\
\hline Total & 111 & 703 & 267 & 195 & 491 & 393 & 1,220 & 382 \\
\hline \multicolumn{9}{|c|}{ \# weekly records for ${ }^{1}:$} \\
\hline DMI & 4,090 & $\begin{array}{l}24,99 \\
4\end{array}$ & 0 & 4,105 & $\begin{array}{l}11,08 \\
6\end{array}$ & 9,270 & 15,731 & 0 \\
\hline FPCM & 3,472 & $\begin{array}{l}23,85 \\
3\end{array}$ & 790 & 2,503 & $\begin{array}{l}10,47 \\
6\end{array}$ & 9,141 & 19,679 & 668 \\
\hline BW & 2,813 & $\begin{array}{l}24,81 \\
2\end{array}$ & 800 & 3,925 & $\begin{array}{l}10,46 \\
0\end{array}$ & 8,875 & 21,935 & 679 \\
\hline $\mathrm{CH} 4 \mathrm{c}$ & 0 & 5,212 & 800 & 0 & 0 & 0 & 5,904 & 2,496 \\
\hline $\mathrm{CO} 2 \mathrm{c}$ & 0 & 5,212 & 800 & 0 & 0 & 0 & 5,904 & 2,496 \\
\hline Total & 4,355 & $\begin{array}{l}25,37 \\
1\end{array}$ & 800 & 4,105 & $\begin{array}{l}11,08 \\
6\end{array}$ & 9,270 & 22,895 & 2,496 \\
\hline $\begin{array}{l}\text { Weeks in } \\
\text { lactation }\end{array}$ & $1-44$ & $1-44$ & $1-44$ & $1-44$ & $1-44$ & $1-44$ & $1-44$ & $1-44$ \\
\hline $\begin{array}{l}\text { Gas recording } \\
\text { period }\end{array}$ & $\mathrm{N} / \mathrm{A}$ & $\begin{array}{l}2013- \\
2016\end{array}$ & $\begin{array}{l}2014- \\
2016\end{array}$ & $\mathrm{~N} / \mathrm{A}$ & $\mathrm{N} / \mathrm{A}$ & N/A & $\begin{array}{l}2013- \\
2016\end{array}$ & $\begin{array}{l}2014- \\
2016\end{array}$ \\
\hline DMI recording & $\begin{array}{l}1997- \\
2001\end{array}$ & $\begin{array}{l}2002- \\
2016\end{array}$ & $\mathrm{~N} / \mathrm{A}$ & $\begin{array}{l}1991 \\
- \\
2004\end{array}$ & $\begin{array}{l}1991 \\
- \\
2005\end{array}$ & $\begin{array}{l}1991 \\
- \\
1998\end{array}$ & $\begin{array}{l}1990- \\
2016\end{array}$ & N/A \\
\hline Published & $\begin{array}{l}\text { Nielse } \\
n \text { et al } \\
2003\end{array}$ & $\begin{array}{l}\text { Li et al } \\
2016\end{array}$ & $\begin{array}{l}\text { Unpub } \\
\text { lished }\end{array}$ & $\begin{array}{l}\text { Beer } \\
\text { da et } \\
\text { al } \\
2007\end{array}$ & $\begin{array}{l}\text { Veer } \\
\text { kamp } \\
\text { et al. } \\
2000\end{array}$ & $\begin{array}{l}\text { Unpu } \\
\text { blish } \\
\text { ed }\end{array}$ & $\begin{array}{l}\text { Zom et } \\
\text { al } 2012\end{array}$ & $\begin{array}{l}\text { Van } \\
\text { Engelen } \\
\text { et al } \\
2018\end{array}$ \\
\hline
\end{tabular}

${ }^{1} \mathrm{DMI}=$ Dry matter intake; $\mathrm{FPCM}=$ fat and protein corrected milk yield; $\mathrm{BW}=$ body weight; $\mathrm{CH} 4 \mathrm{c}=$ methane breath concentration and $\mathrm{CO} 2 \mathrm{c}=$ carbon dioxide breath concentration. 


\subsubsection{Statistical Analysis}

Cows had multiple records for $\mathrm{CH} 4 \mathrm{c}$ and $\mathrm{CO} 2 \mathrm{c}$ per day made at different times per day. The starting time for each visit in the AMS was converted to $24 \mathrm{~h}$ angular radians for further modelling of diurnal variation in a Fourier series approach (Lassen et al., 2012). A pre-correction model within AMS group for all herds in all countries was used to estimate the daily breath gas concentration free of the effects of diurnal variation, sensor drift after calibration and test day variation between calibrations:

$$
y_{i j k l m}=\mu+d_{i}+b_{j}+\sum^{3} k=1\left(f_{1 k} \sin \vartheta+f_{2 k} \cos \vartheta\right)+c_{l}+e_{i j k l m}
$$

where $y_{i j k l m}$ is the natural logarithm of background corrected AMS visit means of $\mathrm{CH} 4 \mathrm{c}$ and $\mathrm{CO} 2 \mathrm{c}$; $d_{i}$ is the fixed effect of test day $i ; b_{j}$ is the fixed effect of the first full day after each calibration $j ; f_{1 k}$ and $f_{2 k}$ are the fixed regression coefficients of Fourier series linear covariates of the time of day of measurement, modelled as harmonic pairs. Here $\theta$ denotes the time of day of visit expressed as $24 \mathrm{~h}$ angular radians. Term $c_{1}$ is the random effect parameters for each cow $c_{1} \sim N D\left(0, \sigma^{2}{ }_{c}\right)$, and $\mathrm{e}_{\mathrm{ijklm}}$ is the random residuals $\sim \mathrm{ND}\left(0,1 \sigma^{2} \mathrm{e}\right)$. In order to correct daily AMS visit means, the random residuals for each visit were summed with random cow solutions, intercept, calibration day, and the regression coefficients $f_{1 k}$ and $f_{2 k}$ multiplied by the angular radian corresponding to $12: 00: 00$ a.m. Further, the $\mathrm{CH} 4 \mathrm{c}$ and the $\mathrm{CO} 2 \mathrm{c}$ in natural log transformed parts per million as the average per week of lactation was obtained by taking the corrected means of visits weighted by the number of seconds for each visit where the cow head was positioned correctly in the feed bin.

Univariate repeatability mixed models were conducted by use of Proc Mixed in SAS (SAS 9.3, SAS Institute Inc.) where significance of fixed effects was tested using Kenward-Roger correction for the correct denominator degrees of freedom, for all traits within country. The residuals were tested for deviations from normality by means of Kolmogorov-Smirnov normality tests and severe violations were detected for $\mathrm{CH} 4 \mathrm{c}$ and $\mathrm{CO} 2 \mathrm{c}$ which were best remedied by a natural log transformation. The means and variances of $\mathrm{CH} 4 \mathrm{c}$ and $\mathrm{CO} 2 \mathrm{c}$ from different measuring equipment and AMS models (DeLaval and Lely A3 and A4 Astronauts) differed significantly. Based on the results of a pilot study combining data from multiple measuring equipment is was decided to standardize $\mathrm{CH} 4 \mathrm{c}$ and $\mathrm{CO} 2 \mathrm{c}$ within equipment and country to a mean of zero and standard deviation of one (Difford et al., 2016).

A five trait multi-trait analysis was performed to estimate the variance components and the heritability within each country and in a combined country dataset i.e., DMI, FPCM, BW, $\mathrm{CH} 4 \mathrm{C}$ and $\mathrm{CO} 2 \mathrm{c}$. All analyses were performed using 
DMU version 6 (Madsen and Jensen, 2014). The model used in the Danish dataset was as follows:

$$
y_{i j k l m}=\mu+W_{i}+E T C_{j}+a_{l}+p e_{l}+e_{i j k l m}
$$

Where $y_{i j k l m}$ is the trait of interest (DMI, BW, FPCM, CH4c or CO2c), $\mu$ is the intercept, $W$ is the $i^{\text {th }}$ week of lactation, ETC is the $j^{\text {th }}$ experiment by treatment contemporary group effect, $a_{1}$ is the random additive effect of the $I^{\text {th }}$ animal $N(0, A$ $\sigma^{2}{ }_{a}$ ) where $A$ is the pedigree derived numerator relationship matrix, pe is the permanent environmental effect distributed following $\mathrm{N}\left(0, \mathrm{l} \sigma_{\mathrm{pe}}^{2}\right)$ and $\mathrm{e}$ is the random residual $\mathrm{N}\left(0, \mathrm{l} \sigma^{2}{ }_{\mathrm{e}}\right)$. For the feed intake traits (DMI, BW and FPCM) the linear covariate age at first calving was significant and was included in model 2 as a fixed regression.

For the Dutch data it was necessary to place added restrictions on the permanent environmental covariance and residual covariance between $\mathrm{CH} 4 \mathrm{c}, \mathrm{CO} 2 \mathrm{c}$ and $\mathrm{DMI}$ as these were recorded at different time points such that they were undefined:

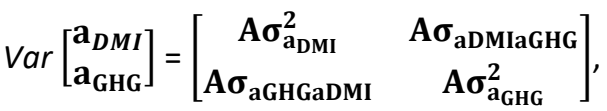

$$
\begin{aligned}
& \operatorname{Var}(p e)=\mathrm{PE}=\left[\begin{array}{cc}
\boldsymbol{\sigma}_{\mathrm{pe}_{\mathrm{FI}}}^{2} & \mathbf{0} \\
\mathbf{0} & \boldsymbol{\sigma}_{p \mathbf{e}_{\mathrm{GHG}}}^{2}
\end{array}\right] \text {, } \\
& \operatorname{Var}(e)=\mathbf{R}=\left[\begin{array}{cc}
\boldsymbol{\sigma}_{\mathbf{e}_{F I}}^{2} & \mathbf{0} \\
\mathbf{0} & \boldsymbol{\sigma}_{\mathbf{G H G}}^{2}
\end{array}\right] \text {, }
\end{aligned}
$$

For the combined dataset the models described in (2) above were then run without placing any restrictions on the covariances between $\mathrm{CH} 4 \mathrm{c}, \mathrm{CO} 2 \mathrm{c}$ and DMI.

Feed efficiency. The $5 \times 5$ variance covariance matrices estimated from the Danish, Dutch and combined country dataset were used to estimate genetic residual feed intake (gRFI) as per (Kennedy et al., 1993; Shirali et al., 2017). In which $\widehat{\boldsymbol{G}}$ and $\widehat{\boldsymbol{P}}$ are $5 \times 5$ additive genetic and phenotypic variance covariance matrices, respectively, for feed intake traits (FI), i.e. DMI, FPCM, BW, green house gas traits (GHG) i.e. CH4c and $\mathrm{CO} 2 \mathrm{c}$. Firstly, the multivariate genetic partial regression coefficients $\hat{b}_{1}$ and $\hat{b}_{2}$ of FPCM and BW on DMI are estimated respectively. The partial genetic regression coefficients were computed using genetic variance covariance matrices as $\widehat{b}_{D M I|F P C M, B W|}=\widehat{\boldsymbol{G}}_{D M I|F P C M, B W|} \widehat{\boldsymbol{G}}^{-\mathbf{1}}{ }_{F P C M, B W}$ in which $\widehat{\boldsymbol{G}}_{F P C M, B W}$ is a $2 \times 2$ genetic variance covariance matrix of FPCM and BW, $\widehat{\boldsymbol{G}}_{D M I|F P C M, B W|}$ is a $1 \times 2$ covariance vector of FPCM and BW on DMI, resulting in a $1 \times 2$ vector of genetic partial regression coefficients. 
The genetic RFI which has DMI genetically orthogonal of FPCM and BW estimated using genetic partial regression coefficients computed above in the following covariance function:

$$
B=\left[\begin{array}{ccccc}
I_{D M I} & 0 & 0 & 0 & 0 \\
0 & I_{F P C M} & 0 & 0 & 0 \\
0 & 0 & I_{B W} & 0 & 0 \\
0 & 0 & 0 & I_{C H 4 c} & 0 \\
0 & 0 & 0 & 0 & I_{C O 2 c} \\
I_{D M I} & -\hat{b}_{1} & -\hat{b}_{2} & 0 & 0
\end{array}\right]
$$

Thus $B$ is a $6 \times 5$ identify matrix which is pre- and post multiplied on the $5 x$ $5 \widehat{\boldsymbol{G}}$ and $\widehat{\boldsymbol{P}}$ matrices (i.e. $B \widehat{\boldsymbol{G}} B^{\prime}$ ) to obtain a $6 \times 6$ genetic and phenotypic variance covariance matrices including the newly computed gRFI which has the favorable properties of being genetically uncorrelated to FPCM and BW i.e. $\widehat{G}_{R F I|F P C M, B W|}=$ $\widehat{\boldsymbol{G}}_{D M I|F P C M, B W|}-\widehat{b}_{D M I|F P C M, B W|} \widehat{\boldsymbol{G}}_{F P C M, B W}=0$.

\subsubsection{Selection index calculations}

Selection index theory was used to evaluate different recording strategies with $\mathrm{FI}$ and GHG trait combinations ( $\mathrm{I}$ ) on the selection goals $(\mathrm{H})$ defined by DMI or RFI for bulls with daughter records by calculating selection accuracy $\left(r_{H, I}\right)$ (Falconer and Mackay, 1996):

$$
r_{H, I}=\sqrt{\frac{\boldsymbol{b}^{\prime} \boldsymbol{P} \boldsymbol{b}}{\boldsymbol{v}^{\prime} \boldsymbol{G} \boldsymbol{v}}}
$$

Where, $r_{H, l}$ is the accuracy of the index, $\mathbf{b}$ is the $6 \times 1$ vector of weighing factors for each of the records used in making selection decisions. $\mathbf{P}$ is the $6 \times 6$ matrix of phenotypic (co)variance among records of each trait; $\mathbf{v}$ is the $6 \times 1$ vector of relative economic values and $\mathrm{G}$ is the genetic (co)variance matrix among traits. To focus on recording strategies for RFI or DMI, we arbitrarily assigned a value of one to the respective selection goal and zero to all other traits in $\mathbf{v}$. As there is a large disparity in the throughput of different traits, combinations were evaluated assuming bulls had 100 daughters with single average weekly records of $\mathrm{CH} 4 \mathrm{c}, \mathrm{CO} 2 \mathrm{c}$, BW and ECM (a realistic assumption in AMS herds) and 10 daughters with single weekly average DMI records (a realistic assumption with research and nucleus herds) using the excel macro of (van der Werf, 2017).

\subsection{Results}




\subsubsection{Descriptive statistics}

Descriptive statistics of FI related and GHG related traits for DNK and NLD are shown in Table 4.2. The averages for FI related traits were marginally higher for DNK than for NLD with DMI $19.5 \mathrm{~kg} / \mathrm{d}$ in DNK and $18.8 \mathrm{~kg} / \mathrm{d}$ in NLD, FPCM was 28.9 $\mathrm{kg} / \mathrm{d}$ in DNK and $28.3 \mathrm{~kg} / \mathrm{d}$ in NLD and BW was larger $604.2 \mathrm{~kg}$ in DNK than in NLD 556.6. The GHG traits were likewise comparable between the countries, with $\mathrm{CH} 4 \mathrm{c}$ higher in NLD and $5.9 \mathrm{ln}(\mathrm{ppm} / \mathrm{d})$ than DNK $5.6 \mathrm{ln}(\mathrm{ppm} / \mathrm{d})$. Whilst, CO2c was higher in DNK $8.5 \ln (\mathrm{ppm} / \mathrm{d})$ compared with $8.3 \ln (\mathrm{ppm} / \mathrm{d})$ in NLD.

\subsubsection{Genetic parameters}

The estimated genetic variances, heritability and repeatability for Danish, Dutch and the combined datasets are shown in Table 4.3. In general, all estimates were higher for traits in DNK as compared to NLD and the combined country dataset, FI related traits had higher heritability and repeatability than GHG related traits.

Feed intake related traits. Estimated heritability for DMI was 0.41 in DNK, 0.21 in NLD and 0.29 in the combined datasets with SE ranging from 0.03 to 0.06 . The repeatability of DMI was more consistent with 0.64 in DNK and 0.59 in NLD and the combined dataset. Heritability estimates for FPCM followed a similar pattern as DMI across datasets with the highest estimate in DNK of 0.48 , lowest in NLD 0.20 and intermediate in the combined dataset 0.35 . Body weight was the most heritable trait in all datasets with 0.57 in DNK, 0.49 in NLD and 0.45 in the combined dataset.

Greenhouse gas related traits. The $\mathrm{h}^{2}$ estimates of $\mathrm{CH} 4 \mathrm{c}$ and $\mathrm{CO} 2 \mathrm{c}$ were similar within and across datasets. The heritability of $\mathrm{CH} 4 \mathrm{c}$ was highest in DNK 0.26 , followed by the combined dataset 0.22 and NLD 0.16 . Similarly, heritability of CO2c was 0.23 in DNK and the combined dataset and 0.15 in NLD. The SE of $h^{2}$ was reduced in the combined country data (0.06) such that the $95 \%$ confidence intervals for $\mathrm{h}^{2}$ of $\mathrm{CH} 4 \mathrm{c}$ and $\mathrm{CO} 2 \mathrm{c}$ did not include zero. Both weekly average $\mathrm{CH} 4 \mathrm{c}$ and $\mathrm{CO} 2 \mathrm{c}$ were highly repeatable in DNK 0.72 and 0.73 , in NLD 0.67 and 0.61 and in the combined dataset 0.69 and 0.70 , respectively. 
Table 4.2. Descriptive statistics (No. of weekly records, mean value, standard deviation (sd), minimum (min), maximum (max)) of feed intake related traits and greenhouse gas related traits for each country.

\begin{tabular}{|c|c|c|c|c|c|c|c|c|c|c|c|}
\hline \multirow[b]{2}{*}{ Trait $^{1}$} & \multirow[b]{2}{*}{ Unit } & \multicolumn{5}{|c|}{ Denmark } & \multicolumn{5}{|c|}{ The Netherlands } \\
\hline & & $\begin{array}{l}\text { No. } \\
\text { weekly } \\
\text { records }\end{array}$ & mean & sd & $\min$ & $\max$ & $\begin{array}{l}\text { No. } \\
\text { weekly } \\
\text { records }\end{array}$ & mean & $\mathrm{sd}$ & $\min$ & $\max$ \\
\hline DMI & $\mathrm{kg} / \mathrm{d}$ & 24,994 & 19.5 & 3.1 & 6.6 & 37.2 & 39,464 & 18.8 & 3.2 & 5.0 & 31.9 \\
\hline FPCM & $\mathrm{kg} / \mathrm{d}$ & 23,906 & 28.9 & 5.8 & 3.0 & 53.0 & 41,454 & 28.3 & 5.0 & 2.9 & 54.8 \\
\hline BW & $\mathrm{kg}$ & 24,908 & 604.2 & 64.9 & 387.0 & 869.0 & 44,649 & 556.6 & 56.9 & 321.8 & 851.6 \\
\hline $\mathrm{CH} 4 \mathrm{C}$ & $\operatorname{Ln}(p p m)$ & 4888 & 5.6 & 0.49 & 3.4 & 7.1 & 8400 & 5.9 & 0.36 & 3.2 & 7.4 \\
\hline $\mathrm{CO} 2 \mathrm{c}$ & $\operatorname{Ln}(p p m)$ & 4888 & 8.5 & 0.30 & 7.4 & 9.68 & 8400 & 8.3 & 0.42 & 6.5 & 9.3 \\
\hline
\end{tabular}

${ }^{1} \mathrm{DMI}=$ Dry matter intake; $\mathrm{FPCM}=$ fat and protein corrected milk yield; $\mathrm{BW}=$ body weight; $\mathrm{CH} 4 \mathrm{c}=$ natural logarithm of methane breath concentration and $\mathrm{CO} 2 \mathrm{c}=$ natural logarithm of carbon dioxide breath concentration. 
Genetic Residual Feed Intake. For gRFI, the genetic partial regression coefficients of FPCM and BW on DMI differed between the countries with 0.403 and 0.03 in NLD and 0.211 and 0.016 for DNK, respectively. However the relative ratio of regression coefficents was similar across countries. Thus the $h^{2}$ of gRFI was similar in DNK $\left(h^{2}=0.15 \pm 0.04\right)$ to NLD $\left(h^{2}=0.17 \pm 0.04\right)$ (Table 4.3). In all datasets the heritability of gRFI is lower than that of DMI and significant from zero. The estimates of $G$ and $P$ from the combined country increased certainty around the resulting regression coefficients of 0.295 and 0.017 for FPCM and BW on DMI respectively and a low but significant heritability $\left(h^{2}=0.14 \pm 0.03\right)$ (Table 4.3 ).

\subsubsection{Genetic and phenotypic correlations}

Genetic and phenotypic correlations between FI related traits and GHG related traits within DNK, NLD and the combined dataset are presented in Table 4.4. In general, the genetic correlations between $\mathrm{FI}$ traits and GHG traits were similar in all datasets with the exception of gRFI as is discussed below. Furthermore, the standard errors of genetic correlations were far larger in DNK than in NLD and substantially reduced in the combined country dataset, following a trend of increases in numbers of cows.

Feed Intake related traits. DMI was highly genetically and phenotypically correlated with FPCM and moderately with BW. With genetic correlations for FPCM in DNK $\left(r_{\mathrm{g}}=0.79 \pm 0.05\right), \operatorname{NLD}\left(r_{\mathrm{g}}=0.68 \pm 0.05\right)$ and combined $\left(r_{\mathrm{g}}=0.67 \pm 0.05\right)$. Genetic correlations between DMI and BW were somewhat different across datasets with $(0.09 \pm 0.16)$ in DNK and $(0.38 \pm 0.07)$ and combined $(0.39 \pm 0.07)$, although the magnitude of standard errors is limiting inferences into differences. Genetic correlations between FPCM and BW ranged from negative $(-0.51 \pm 0.17)$ in DNK close to zero in NLD and in the combined dataset $(-0.05 \pm 0.08)$. Whilst phenotypic correlations between FPCM and BW were very similar ranging from $(-0.02 \pm 0.05)$ in DNK to $(0.08 \pm 0.02)$ in NLD.

Greenhouse Gas related traits. The genetic correlations between GHG traits and $\mathrm{FI}$ traits were very similar for both countries. DMI was moderately genetically correlated to $\mathrm{CH} 4 \mathrm{c}$, ranging from 0.29 in NLD to 0.58 in DNK, similarly for CO2c estimates ranging from 0.34 in the combined dataset to 0.42 in NLD. The GHG traits also showed similar patterns for genetic correlations with FPCM and BW in both countries, where genetic correlations were positive with FPCM ranging from $(0.24-0.54)$ and low with BW ranging from $(-0.13-0.00)$. The genetic and phenotypic correlations between $\mathrm{CH} 4 \mathrm{c}$ and $\mathrm{CO} 2 \mathrm{c}$ were consistently very high with $\mathrm{r}_{\mathrm{g}}$ ranging from 0.95 in DNK and NLD to 0.96 in the combined dataset. 
Table 4.3. Estimated genetic $\left(\sigma^{2}\right)$ and phenotypic $\left(\sigma^{2}\right)$ variances, heritability $\left(h^{2}\right)$ and repeatability of weekly averages $\left(t^{2}\right)$ with corresponding standard errors (se) in parenthesis from within country and combined country multitrait models.

\begin{tabular}{|c|c|c|c|c|c|c|c|c|c|}
\hline \multicolumn{4}{|c|}{ Denmark } & \multicolumn{3}{|c|}{ The Netherlands } & \multicolumn{3}{|c|}{ Combined Country } \\
\hline Trait $^{1}$ & $\sigma_{a}^{2}$ & $h^{2}$ (se) & $t^{2}(s e)$ & $\sigma_{a}^{2}$ & $h^{2}(\mathrm{se})$ & $t^{2}(s e)$ & $\sigma_{a}^{2}$ & $h^{2}(s e)$ & $t^{2}(s e)$ \\
\hline DMI & 2.38 & $0.41_{(0.06)}$ & $0.64_{(0.02)}$ & 1.08 & $0.21_{(0.04)}$ & $0.59_{(0.01)}$ & 1.63 & $0.29_{(0.03)}$ & $0.59_{(0.01)}$ \\
\hline FPCM & 18.87 & $0.48_{(0.07)}$ & $0.82_{(0.01)}$ & 3.73 & $0.20_{(0.02)}$ & $0.76_{(0.01)}$ & 8.57 & $0.35_{(0.01)}$ & $0.73_{(0.01)}$ \\
\hline BW & 1220.0 & $0.57_{(0.13)}$ & $0.89_{(0.01)}$ & 107 & $0.49_{(0.00)}$ & $0.86_{(0.00)}$ & 1162.7 & $0.45_{(0.00)}$ & $0.86_{(0.01)}$ \\
\hline $\mathrm{CH} 4 \mathrm{C}$ & 0.25 & $0.26_{(0.11)}$ & $0.72_{(0.02)}$ & 0.10 & $0.16_{(0.16)}$ & $0.67_{(0.01)}$ & 0.24 & $0.22_{(0.06)}$ & $0.69(0.01)$ \\
\hline $\mathrm{CO} 2 \mathrm{c}$ & 0.23 & $0.23_{(0.12)}$ & $0.73_{(0.02)}$ & 0.11 & $0.15_{(0.15)}$ & $0.61_{(0.02)}$ & 0.23 & $0.23_{(0.06)}$ & $0.70_{(0.01)}$ \\
\hline gRFI & 0.86 & $0.15_{(0.04)}$ & $0.72_{(0.02)}$ & 0.60 & $0.17_{(0.03)}$ & $0.43_{(0.01)}$ & 0.53 & $0.14_{(0.03)}$ & $0.48_{(0.01)}$ \\
\hline
\end{tabular}

${ }^{1} \mathrm{DMI}=$ Dry matter intake; $\mathrm{FPCM}=$ fat and protein corrected milk yield; $\mathrm{BW}=$ body weight; $\mathrm{CH} 4 \mathrm{c}=$ natural logarithm of methane breath concentration and $\mathrm{CO} 2 \mathrm{c}=$ natural logarithm of carbon dioxide breath concentration. 
Genetic Residual Feed Intake. Within and across countries gRFI was genetically uncorrelated to FPCM and BW (Table 4.4). However, in DNK the genetic correlation between DMI and gRFI was far smaller $\left(r_{g}=0.21 \pm 0.61\right)$ than in The Netherlands $\left(r_{\mathrm{g}}=0.74 \pm .06\right)$. The genetic correlations between gRFI and GHG traits were negative in Denmark with $\left(r_{g}=-0.17 \pm 0.85\right)$ and $\left(r_{g}=-0.22 \pm 0.95\right)$ between $\mathrm{CH} 4 \mathrm{c}$ and $\mathrm{CO} 2 \mathrm{c}$ with gRFI respectively. Similarly, in The Netherlands $\left(r_{\mathrm{g}}=-0.52 \pm 0.32\right)$ and $\left(r_{g}=-0.44 \pm 0.32\right)$ for $\mathrm{CH} 4 \mathrm{c}$ and $\mathrm{CO} 2 \mathrm{c}$ with gRFI respectively. In the combined country dataset gRFI remained genetically uncorrelated to FPCM ( $r g=0.05 \pm 0.09$ ) and $\mathrm{BW}(\mathrm{rg}=0.00 \pm 0.09)$. Whilst a strong positive genetic correlation with a substantially reduced standard error persisted with DMI ( $r g=0.64 \pm 0.04)$ (Table 4.4). In the combined dataset the genetic correlations between both $\mathrm{CH} 4 \mathrm{c}$ and $\mathrm{CO} 2 \mathrm{c}$ with gRFI were positive $\left(r_{\mathrm{g}}=0.33 \pm 0.15\right)$ and $\left(r_{\mathrm{g}}=0.32 \pm 0.15\right)$.

\subsubsection{Prediction accuracy of selection indices for DMI and gRFI}

The accuracy of bull selection goals for DMI or gRFI based on the combined country estimated $\mathrm{G}$ and $\mathrm{P}$ (co)variance matrices for several recording strategies for daughters using different combinations of FI and GHG traits are presented in Table 4.5. For both $\mathrm{DMI}$ and gRFI indices, including DMI daughter records gave higher accuracies than indices including only GHG or FPCM and BW. For DMI, accuracy with GHG traits was lower (0.43) than FPCM and BW (0.75) although, the accuracy of FPCM, BW and GHG traits (0.78) was comparable to the same index including DMI (0.83). Conversely, for accuracy of gRFI the contribution of FPCM and BW was negligible (0.05) as compared to the modest contributions of GHG traits (0.30). Furthermore, the accuracy of gRFI based on DMI and GHG traits (0.47) exceed the accuracy of DMI alone (0.42) and was equivalent to DMI, FPCM and BW (0.47). The highest accuracy for gRFI (0.53) was achieved using all recoding traits including DMI. 
Table 4.4. Genetic (below diagonal) and phenoypic (above diagonal) correlations between feed intake-related traits ${ }^{1}$, greenhouse as related traits ${ }^{2}$ and feed efficiency restricted indices ${ }^{3}$, with corresponding standard errors in parenthesis for Denmark, The Netherlands and the combined dataset.

\begin{tabular}{|c|c|c|c|c|c|c|}
\hline \multirow[t]{2}{*}{ Traits } & \multicolumn{6}{|l|}{ Denmark } \\
\hline & DMI & FPCM & BW & gRFI & $\mathrm{CH} 4 \mathrm{c}$ & $\mathrm{CO} 2 \mathrm{c}$ \\
\hline DMI & & $0.56_{(0.02)}$ & $0.30_{(0.05)}$ & $0.20_{(0.03)}$ & $0.35(0.05)$ & $0.23_{(0.05)}$ \\
\hline FPCM & $0.79_{(0.05)}$ & & $-0.02(0.05)$ & $-0.47(0.02)$ & $0.31_{(0.05)}$ & $0.17(0.05)$ \\
\hline BW & $0.09_{(0.16)}$ & $-0.51(0.17)$ & & $-0.41(0.02)$ & $0.12(0.06)$ & $0.09_{(0.06)}$ \\
\hline \multirow[t]{2}{*}{ gRFI } & $0.21_{(0.64)}$ & $0.002(0.58)$ & 0.004 & & $-0.06(0.04)$ & $0.04_{(0.04)}$ \\
\hline & & & $(0.71)$ & & & \\
\hline $\mathrm{CH} 4 \mathrm{c}$ & $0.58(0.19)$ & $0.54_{(0.20)}$ & $0.00_{(0.26)}$ & $-0.17(0.85)$ & & $0.91_{(0.00)}$ \\
\hline \multirow[t]{2}{*}{$\mathrm{CO} 2 \mathrm{c}$} & $0.36_{(0.23)}$ & $0.37_{(0.20)}$ & $-0.02(0.28)$ & $-0.22(0.95)$ & $0.95_{(0.04)}$ & \\
\hline & The Nethe & nds & & & & \\
\hline DMI & & $0.47_{(0.01)}$ & $0.31_{(0.02)}$ & $0.85_{(0.00)}$ & $-0.02(0.08)$ & $-0.01(0.08)$ \\
\hline FPCM & $0.68(0.05)$ & & $0.08(0.02)$ & $0.06_{(0.02)}$ & $0.11_{(0.03)}$ & $0.11_{(0.03)}$ \\
\hline BW & $0.38(0.07)$ & $-0.05(0.08)$ & & $-0.06(0.02)$ & $0.06_{(0.04)}$ & $0.08(0.03)$ \\
\hline gRFI & $0.74_{(0.06)}$ & $0.00_{(0.15)}$ & $0.00_{(0.11)}$ & & $-0.09(0.09)$ & $-0.10_{(0.09)}$ \\
\hline $\mathrm{CH} 4 \mathrm{c}$ & $0.29(0.14)$ & $0.24(0.13)$ & $-0.13(0.14)$ & $-0.52(0.32)$ & & $0.87_{(0.00)}$ \\
\hline \multirow[t]{2}{*}{$\mathrm{CO} 2 \mathrm{c}$} & $0.42(0.14)$ & $0.35_{(0.12)}$ & $-0.12(0.13)$ & $-0.44(0.32)$ & $0.95(0.02)$ & \\
\hline & Combinec & taset & & & & \\
\hline DMI & & $0.59_{(0.01)}$ & $0.29_{(0.02)}$ & $0.72_{(0.01)}$ & $0.29_{(0.03)}$ & $0.22(0.03)$ \\
\hline FPCM & $0.67_{(0.05)}$ & & $0.05_{(0.02)}$ & $-0.11_{(0.01)}$ & $0.20_{(0.03)}$ & $0.14_{(0.03)}$ \\
\hline BW & $0.39_{(0.07)}$ & $-0.05(0.08)$ & & $-0.07(0.02)$ & $0.03(0.04)$ & $0.03(0.04)$ \\
\hline gRFI & $0.64(0.04)$ & $0.05_{(0.09)}$ & $0.00_{(0.09)}$ & & $0.20_{(0.03)}$ & $0.16_{(0.04)}$ \\
\hline $\mathrm{CH} 4 \mathrm{C}$ & $0.41_{(0.12)}$ & $0.35(0.11)$ & $-0.06(0.11)$ & $0.33_{(0.15)}$ & & $0.92(0.00)$ \\
\hline $\mathrm{CO} 2 \mathrm{c}$ & $0.34_{(0.12)}$ & $0.27_{(0.11)}$ & $-0.08(0.11)$ & $0.32(0.15)$ & $0.96_{(0.00)}$ & \\
\hline
\end{tabular}

${ }^{1}$ Feed intake-related traits: $\mathrm{DMI}=$ dry matter intake; fat and protein corrected milk yield $=\mathrm{FPCM}$; and body weight $=\mathrm{BW} .{ }^{2}$ Greenhouse gas related traits: natural logarithm of methane breath concentration $=\mathrm{CH} 4 \mathrm{c}$; and natural logarithm of carbon dioxide breath concentration $=\mathrm{CO} 2 \mathrm{c} .{ }^{3} \mathrm{Feed}$ efficiency restricted indices: genetic residual feed intake $=$ gRFI. 


\subsection{Discussion}

\subsubsection{Genetic parameters}

Feed intake related traits. Investigations into the $\mathrm{Fl}$ related traits $\mathrm{DMI}$, FPCM and BW; have been an area of intense research in both countries with both being members of international collaborative consortia like gDMI (Berry et al., 2014). The heritability estimate for DMI (0.41) was slightly higher than reported previously for Nordic Holsteins $(0.20-0.40)$ by Li et al. (2016). However, Li et al. (2016) estimated $h^{2}$ for $1-24$ weeks of lactation with an increasing trend from 0.20 to 0.40 , whilst we reported entire lactation $\mathrm{h}^{2}$ from weeks 1-44. Similarly, the $\mathrm{h}^{2}$ estimate for DMI in NLD was within the lower range of reported values from previous studies (0.15 - 0.41) (Koenen and Veerkamp, 1998; Vallimont et al., 2010). In the present study, parameters are estimated over the course of the entire first lactation, recognizing that previous findings from both populations demonstrate that the genetic parameters of DMI, FPCM and BW change over the course of lactation (Manzanilla Pech et al., 2014; Li et al., 2016). The genetic correlations between both countries have been estimated as close to unity (0.80-0.99) (de Haas et al., 2012), indicating the potential to estimate parameters jointly over the two populations. Indeed, for the combined population DMI had $\left(h^{2}=0.29 \pm 0.03\right)$ comparable to a large study with over 10,000 animals from 9 countries in the gDMI consortium (Berry et al., 2014).

The $\mathrm{h}^{2}$ estimates for BW are well within the reported ranges in DNK for multiparous Nordic cattle breeds (0.52 - 0.77) (Sondergaard et al., 2002; Sloniewski et al., 2005) and primiparous Dutch Holstein Friesian cows (0.22 - 0.74) (Koenen and Veerkamp, 1998; Manzanilla Pech et al., 2014). Similarly, $h^{2}$ estimates for FPCM were within range of previous findings in NLD $(0.22-0.43)$ (Manzanilla Pech et al., 2014). However, the $h^{2}$ estimate for FPCM was larger than those reported for ECM in DNK (0.27-0.39) (Sondergaard et al., 2002; Lassen and Løvendahl, 2016). Recognizing that the two trait definitions differ due to different linear combinations of milk yield, fat yield and protein yield, with FPCM 1.9\% MY, 64.7\% fat yield and 33.4\% protein yield (CVB, 2008) and ECM 1.2\% MY, 60.5\% fat yield and, 38.2\% protein yield (Sjaunja et al., 1991). The choice of FPCM was driven by need to make findings of this study comparable to international research efforts for GHG mitigation (FAO, 2010).

Greenhouse gas related traits. The $\mathrm{h}^{2}$ estimates of $\mathrm{CH} 4 \mathrm{c}$ and $\mathrm{CO} 2 \mathrm{c}$ were consistent across datasets with estimates in the combined country dataset of 0.22 and 0.23 , both significant from 0 , respectively. These are substantially larger than those reported for primi- and multiparous Dutch Holsteins Friesians in commercial 
herds $\mathrm{CH} 4 \mathrm{c}\left(\mathrm{h}^{2}=0.11 \pm 0.02\right)$ and $\mathrm{CO} 2 \mathrm{c}\left(\mathrm{h}^{2}=0.12 \pm 0.02\right)$ (van Engelen et al., 2018), of which the primiparous cows are part of this study. However, the estimates of (van Engelen et al., 2018) are based on the mean $\mathrm{CH} 4 \mathrm{c}$ and $\mathrm{CO} 2 \mathrm{c}$ per milking, whilst the present study makes use of an average per week of lactation and thus far more repeated measures per animal as was shown to be an effective error reduction technique with sniffers (Difford et al., 2016). The present estimates are also larger than the ratio of $\mathrm{CH} 4 \mathrm{c}$ to $\mathrm{CO} 2 \mathrm{c}(\mathrm{CH} 4 \mathrm{c} / \mathrm{CO} 2 \mathrm{c})$ in multiparous Danish Holstein $\left(\mathrm{h}^{2}=0.16\right.$ \pm 0.04 ) (Lassen and Løvendahl, 2016) and Dutch Holstein Friesians cows $\left(h^{2}=0.03 \pm\right.$ 0.01) (van Engelen et al., 2018). Although $\mathrm{CH} 4 \mathrm{c}$ and $\mathrm{CO} 2 \mathrm{c}$ are short term breath concentration measures, the $\mathrm{h}^{2}$ estimates are comparable to that of $24 \mathrm{hr}$ total mass flux $\mathrm{CH}_{4}$ production from respiration chambers in over 1000 growing Aberdeen Angus ( $h^{2}=0.22 \pm 0.06$ ) (Donoghue et al., 2016) and 1225 dual purpose mixed and composite sheep $\left(h^{2}=0.29 \pm 0.05\right)$ using portable accumulation chambers (PinaresPatiño et al., 2013).

\subsubsection{Genetic correlations}

Feed Intake related traits. DMI was highly genetically and phenotypically correlated with FPCM and moderately with BW. With genetic correlations for FPCM in DNK $\left(r_{\mathrm{g}}=0.79 \pm 0.05\right)$, NLD $\left(r_{\mathrm{g}}=0.68 \pm 0.05\right)$ and combined $\left(r_{\mathrm{g}}=0.67 \pm 0.05\right)$ in range of estimates in repeatability model studies $(0.57-0.86)$ (Huttmann et al., 2009; Manzanilla Pech et al., 2014; Manzanilla-Pech et al., 2016). Genetic correlations between $\mathrm{DMI}$ and $\mathrm{BW}$ were somewhat different across datasets with $(0.09 \pm 0.16)$ in DNK and $(0.38 \pm 0.07)$ and combined $(0.39 \pm 0.07)$, although the magnitude of standard errors is limiting inferences into differences, the estimates were close to the ranges reported in literature (0.17-0.45) (Huttmann et al., 2009; Manzanilla-Pech et al., 2016). Genetic correlations between FPCM and BW ranged from negative $(-0.51 \pm 0.17)$ in DNK close to zero in NLD and in the combined dataset $(-0.05 \pm 0.08)$ falling within ranges of estimates in literature (ECM and FPCM) $(-0.36$ - 0.04) (Huttmann et al., 2009; Manzanilla Pech et al., 2014; Lassen and Løvendahl, 2016).

Greenhouse gas related traits. These are the first reported genetic correlations for breath gas concentration measures and FI related traits which makes comparisons and validations from literature challenging. Recently, genetic correlations have been reported for $\mathrm{CH}_{4}$ production using the SF6 method in 314 multiparous Australian Holsteins under grazing conditions (Breider et al., 2018). The genetic correlations between $\mathrm{CH} 4 \mathrm{c}$ and mass flux $\mathrm{CH}_{4}$ production is not currently known and would be of value to assess the merit of $\mathrm{CH} 4 \mathrm{C}$ as an indicator trait for $\mathrm{CH}_{4}$ 
production. The phenotypic correlation between $\mathrm{CH} 4 \mathrm{c}$ and a mass flux of $\mathrm{CH}_{4}$ production is unlikely to be unity, based on $\mathrm{R}^{2}$ values from comparisons of using the artificial reference cow or GreenFeed (C-Lock Inc, SD, USA) (Huhtanen et al., 2015; Wu et al., 2018). However, it is likely positive and in the range of $\left(r_{p}=0.29-0.97\right)$ depending on extraneous factors like cow muzzle position from the sniffer inlet and wind speed (Huhtanen et al., 2015; Wu et al., 2018). Moreover, the correlation between $\mathrm{CH}_{4}$ production and $\mathrm{FI}$ related traits can provide some insight into the expected nature of $\mathrm{CH} 4 \mathrm{C}$ and $\mathrm{FI}$ traits. Breider et al (2018) found $\mathrm{CH}_{4}$ production to be moderate genetically correlated to DMI $\left(r_{\mathrm{g}}=0.34 \pm 0.22\right), \mathrm{MY}\left(r_{\mathrm{g}}=0.26 \pm 0.27\right)$ and BW ( $\left.r_{\mathrm{g}}=0.42 \pm 0.16\right)$. Similarly, (Lassen and Løvendahl, 2016) reported genetic correlations between the ratio of $\mathrm{CH} 4 \mathrm{c} / \mathrm{CO} 2 \mathrm{c}$ with ECM of $\left(r_{\mathrm{g}}=0.04 \pm 0.06\right)$ and $\left(r_{\mathrm{g}}=\right.$ $-0.12 \pm 0.08)$ with BW in multiparous Danish Holsteins. Supporting the notion that genetic correlations between $\mathrm{FI}$ related traits and $\mathrm{CH} 4 \mathrm{c}$ are in the expected range.

Interestingly, the genetic and phenotypic correlations between $\mathrm{CH} 4 \mathrm{c}$ and CO2c were close to unity with (0.95 and 0.91, in DNK respectively and 0.95 and 0.87 in NLD). Studies using the intensive gold standard method have reported phenotypic correlations as high as 0.96 between mass flux $\mathrm{CH}_{4}$ production and $\mathrm{CO}_{2}$ production (Aubry and Yan, 2015), however no studies have reported genetic correlations between these traits. With such high genetic correlations between the two gases, it is imperative that these results are confirmed in future studies, preferably employing as alternative methods of gas measurement to ensure these correlations are not an artifact of the gas sampling method.

\subsubsection{The relationship between GHG traits and feed efficiency}

Both GHG traits had weak to moderate negative genetic correlations with gRFI in DNK and NLD datasets with large SE (Table 4.4). In DNK, 478 primiparous cows had repeated weekly records for GHG traits, $44 \%$ of which had full lactation concurrent records for GHG traits and FI traits. In NLD 660 primiparous cows had repeated weekly records for GHG traits for part of lactation, $42 \%$ of which had DMI records in the first 70 days in milk, resultantly no cows had concurrent GHG and FI traits. Combining the two datasets greatly reduced the standard errors on genetic correlations between GHG and FI traits, likely due to having larger numbers of cows with full lactation concurrent records with DMI and GHG traits. Interestingly, in the combined county dataset moderate positive genetic correlations between gRFI and $\mathrm{CH} 4 \mathrm{c}\left(r_{\mathrm{g}}=0.33 \pm 0.15\right)$ and $\mathrm{CO} 2 \mathrm{c}\left(r_{\mathrm{g}}=0.32 \pm 0.15\right)$ which were significant from zero.

The relationship between $\mathrm{CH}_{4}$ emission and feed efficiency is a hotly contended topic, with inconsistent results between phenotypic RFI and $\mathrm{CH}_{4}$ 
production. Positive phenotypic correlations ( $r p=0.10-0.56$ ) between residual energy intake and $\mathrm{CH}_{4}$ production predicted from energy intake and the ratio of $\mathrm{CH} 4 \mathrm{C}$ / CO2c from sniffers in concentrate feeders were reported for 412 lactating Nordic red cattle in a long term study (Negussie et al., 2014). Similarly, a study using the GreenFeed system found efficient phenotypic RFI groups to have significantly reduced $\mathrm{DMI}, \mathrm{CH}_{4}$ and $\mathrm{CO}_{2}$ production as compared to inefficient RFI groups (Hailemariam et al., 2016). To date only a single genetic correlation of $\left(r_{g}=0.72\right)$ between $\mathrm{CH}_{4}$ production predicted from gross energy intake and phenotypic RFI has been reported (de Haas et al., 2011). Breider et al (2018) investigated the responses to selection in $\mathrm{DMI}, \mathrm{MY}, \mathrm{BW}$ and $\mathrm{CH}_{4}$ production from $\mathrm{SF} 6$, using restricted selection indices in Australian Holsteins on pasture. However, the index for reducing DMI and restricting $\mathrm{MY}$ and $\mathrm{BW}$ (gRFI) showed a correlated increase in $\mathrm{CH}_{4}$ production, indicating genetically feed efficient cows produce more $\mathrm{CH}_{4}$ production. However, using the estimated parameters from Breider et al (2018) and the methods described in Kennedy et al (1993) it is possible to estimated genetic correlation between gRFI and $\mathrm{CH}_{4}$ production which was small $r_{\mathrm{g}}=-0.004$ (Breider et al., 2018).

The inconsistencies in identifying the genetic correlation between GHG traits and feed efficiency in the aforementioned studies could be due to differences in environment and diet (grazing vs TMR), trait definitions (gRFI vs phenotypic RFI) and $\mathrm{CH}_{4}$ emission $\left(\mathrm{CH}_{4}\right.$ production vs $\mathrm{CH} 4 \mathrm{c}$ ) as well as $\mathrm{CH}_{4}$ measurement methods (Sniffers, GreenFeed and SF6). Within the present study however, the differences in genetic correlations between gRFI and GHG traits within countries and the combined dataset are due to the uncertainty around estimating gRFI and GHG traits due to limited concurrent full lactation records within country, as genetic correlations between FI traits and GHG traits did not differ substantial from the within country estimates. From the findings in the present study genetic improvement in gRFI will likely have favorable correlated responses in $\mathrm{CH} 4 \mathrm{c}$ and $\mathrm{CO} 2 \mathrm{c}$, but far larger studies are needed to obtain more accurate estimates. Moreover, the genetic correlation between $\mathrm{CH} 4 \mathrm{c}$ recorded during milking and full $24 \mathrm{hr}$ mass flux $\mathrm{CH}_{4}$ production is not currently known (Pickering et al., 2013). Should the genetic correlation between $\mathrm{CH} 4 \mathrm{C}$ and $\mathrm{CO} 2 \mathrm{c}$ traits prove to be positive with mass flux $\mathrm{CH}_{4}$ production, there is scope to use breath gas concentration measures as large scale indicator traits for reducing $\mathrm{CH}_{4}$ emissions in dairy cattle. The findings of these studies and the relative instability of gRFI within countries highlights the difficulties in estimating feed efficiency in small research or nucleus herds and this impacts the certainty around correlations with $\mathrm{CH}_{4}$ emissions. However, they do suggest that reducing DMI whilst 
maintain FPCM and BW is feasible and will likely result in decreases in $\mathrm{CH} 4 \mathrm{C}$ and $\mathrm{CH}_{4}$ production.

\subsubsection{Defining feed efficiency as a restricted selection index}

Kennedy et al (1993) demonstrated that defining genetic partial regression coefficients of energy sinks (gRFI) derived from multi-trait analyses could overcome the limitations of missing data and lactation stage bias inherent in RFI by defining gRFI as the portion of DMI breeding values that are genetically independent of energy sinks. This multi-trait approach has further advantages of allowing extension to random regression models over lactation (Lu et al., 2015; Moraes et al., 2015; Shirali et al., 2015), and extended to horizontal modelling which allows for adjustment of traits measured infrequently for example traits recorded during the dry periods (Shirali et al., 2017). However, this method assumes that the genetic (G) and phenotypic $(\mathrm{P})$ (co)variance matrices are estimated without error, which is rarely true in practice and thus the partial genetic regression coefficients can be biased.

Estimating $\mathrm{G}$ and $\mathrm{P}$ and subsequently gRFI within country was challenging as cows with records for DMI were limiting, particularly in DNK with 812 primiparous cows with DMI records, as compared to NLN with near triple this number. Combining datasets reduced the uncertainty around genetic correlations between gRFI and $\mathrm{FI}$ related traits. Despite the near unity genetic correlation in DMI in the two countries (de Haas et al., 2012), the possible presence of genotype by environment interaction between the two countries for gRFI and the possible introduction of bias to estimates from unknown extraneous factors in spatial and temporal data with additive genetics cannot be discounted. Neither country had sufficient numbers of cows with DMI records to estimate gRFI within country with high levels of certainty. The combined dataset allowed for estimation of feed efficiency (gRF), which remained genetically uncorrelated to FPCM $\left(r_{g}=0.05 \pm 0.09\right)$ and BW $\left(r_{g}=0.00 \pm 0.09\right)$ but highly correlated to DMI $\left(r_{g}=0.64 \pm 0.04\right)$. Thus selecting for improved (reduced) gRFI will have a correlated reduction in DMI and likely have little to no unfavorable correlated genetic responses in FPCM and BW. Thus, it is feasible to select for reduced DMI without reducing FPCM and BW, effectively breeding for cows that require less feed to maintain production levels of contemporaries.

Prediction accuracy of selection indices for DMI and gRFI. When assessing the potential of a large scale indicator trait to a scarcely recorded and expensive goal trait, it is important to not only account for the genetic correlations but also the value of increased numbers of records of the indicator trait. The accuracy of selection indices for DMI and gRFI were assessed for bulls using different combinations of FI 
and GHG traits based on the estimated combined country genetic and phenotypic (co)variances and numbers of daughters with single weekly averaged records. For DMI, including GHG traits had limited gains as compared to including FPCM and BW. However, for accuracy of gRFI the contribution of FPCM and BW was negligible (0.05) as compared to the modest contributions of GHG traits (0.30). The addition of DMI records to GHG traits increased accuracy further (0.47) and the highest accuracy of gRFI was achieved recording all traits (0.53). Similarly, Manzanilla-Pech et al (2016) evaluated the accuracy of selection indices for DMI and RFI using conformation traits (stature, chest width and body depth) along with BW and milk energy output in the USA and NLD Holstein populations. The bull accuracies for DMI using conformation traits were 0.43 in NLD and 0.63 in USA and further increased to 0.79 in NLD and 0.97 in USA with the addition of BW and milk energy output (Manzanilla-Pech et al., 2016). Although, Manzanilla-Pech et al (2016) predicted bull EBVs for phenotypic RFI, thus some genetic correlations between RFI and component traits remain, the maximum accuracies obtained using all available traits were low for NLD 0.17 but substantial for USA 0.97, the discrepancy likely due to differences in genetic correlations between RFI and predictor traits. In the present study, gRFI remained largely genetically uncorrelated to BW and FPCM which resulted in low accuracies of bull EBVs only using these traits (0.05), however, only using GHG traits increase accuracies 6 fold to 0.30 demonstrating the value of these traits as indicators of feed efficiency. In a recent study, Zetouni et al (2018) found modest correlations (-0.20 0.01 ) between stature, chest width and body depth) and $\mathrm{CH}_{4}$ production predicted from the ratio of $\mathrm{CH} 4 \mathrm{c} / \mathrm{CO}_{2} \mathrm{c}$ and production traits, indicating $\mathrm{CH} 4 \mathrm{c}$ and $\mathrm{CO} 2 \mathrm{c}$ are likely not co-explaining the same genetic variation in DMI and RFI as body conformation traits. Given these findings, the achieved accuracy of bull EBVs for gRFI in the present study maybe be further increased by the addition of body conformation traits. 
Table 4.5. Selection accuracies for bulls for dry matter intake (DMI) and genetic residual feed intake (gRFI) using differing recording schemes with feed intake related traits $^{1}$ and greenhouse gas related traits ${ }^{2}$.

\begin{tabular}{|c|c|c|}
\hline Selection Indices* & Accuracy (DMI) & Accuracy (gRFI) \\
\hline $\mathrm{DMI}_{10}$ & 0.66 & 0.42 \\
\hline $\mathrm{CH} 4 \mathrm{c}_{100}+\mathrm{CO}_{2} \mathrm{c}_{100}$ & 0.43 & 0.30 \\
\hline $\mathrm{BW}_{100}+\mathrm{FPCM}_{100}$ & 0.75 & 0.05 \\
\hline $\mathrm{DMI}_{10}+\mathrm{CH}_{4} \mathrm{c}_{100}+\mathrm{CO}_{2} \mathrm{c}_{100}$ & 0.70 & 0.47 \\
\hline $\mathrm{DMI}_{10}+\mathrm{BW}_{100}+\mathrm{FPCM}_{100}$ & 0.81 & 0.47 \\
\hline $\mathrm{BW}_{100}+\mathrm{FPCM}_{100}+\mathrm{CH} 4 \mathrm{c}_{100}+\mathrm{CO}_{2} \mathrm{c}_{100}$ & 0.78 & 0.31 \\
\hline $\begin{array}{l}\mathrm{DMI}_{10}+\mathrm{BW}_{100}+\mathrm{FPCM}_{100}+\mathrm{CH} 4 \mathrm{c}_{100}+ \\
\mathrm{CO}_{2} \mathrm{c}_{100}\end{array}$ & 0.83 & 0.53 \\
\hline
\end{tabular}

*Subscripts denote the number of daughters with a single weekly average record for a given trait within a selection index. ${ }^{1}$ Feed intake-related traits: $\mathrm{DMI}=$ dry matter intake; fat and protein corrected milk yield = FPCM; and body weight = BW. ${ }^{2}$ Greenhouse gas related traits: natural logarithm of methane breath concentration $=\mathrm{CH} 4 \mathrm{c}$; and natural logarithm of carbon dioxide breath concentration $=\mathrm{CO} 2 \mathrm{c}$.

Implications. GHG traits, FPCM and BW show considerable potential as indicator traits for improving the accuracy of bull EBVs for DMI or gRFI. However, these indicator traits are no substitution for DMI traits, which remain the most costly and limiting trait. In a simulation study Wallén et al., (2017) estimated that genotyped contract herds with 4000 primiparous cows per year phenotype for RFI was feasible for a national breeding scheme giving genomic reference population accuracies comparable to progeny testing schemes with 250 daughter per sire. In the context of the present study; collating data from multiple research herds in DNK and NLD, over a period of three decades approached 3000 primiparous cows with DMI records. Resultantly, historical and geographical structure within the dataset which could potentially bias the estimation of genetic and phenotypic variation covariance matrices on which gRFI is estimated. This potential problem would be circumvented if suitably large numbers of cows are recorded over lactation for DMI and GHG traits concurrently each year under commercial conditions. By installing sniffer sensors in commercial AMS herds which had integral weighing scales, it was possible to obtain records on over 1000 primiparous cows with GHG traits, BW and FPCM in a tenth of the time it took to obtain 3000 primiparous cows with DMI records. This demonstrates a proof of concept as to how these predictor traits can readily be generated on a large scale under commercial conditions and can supplement DMI records recorded on a small scale in contract herds. Recent, promising developments in 3D camera technologies for measuring feed intake under commercial conditions 
could further supplement availability of DMI and GHG data over lactation, but are still under development (Lassen et al., 2018). Furthermore, should the genetic correlation between $\mathrm{CH} 4 \mathrm{c}$ and mass flux $\mathrm{CH}_{4}$ production using accurate and intensive methods be positive and there is an economic incentive to reduce $\mathrm{CH}_{4}$ emission, there is scope for $\mathrm{CH} 4 \mathrm{c}$ to act as a large scale indicator trait for genetic selection of climate friendly cows.

\subsection{Conclusion}

This study showed significant genetic variation for the concentration of methane and carbon dioxide in the breath of lactating Holstein cattle. Furthermore, a restricted selection index approach demonstrated genetic variation for more feed efficient cows with reduced DMI but little to no decreases in FPCM and BW. The genetic correlations between GHG traits, FI traits and feed efficiency open up the possibility for GHG traits as large scale indicator traits for feed efficiency.

\subsection{Acknowledgements}

The authors would like to acknowledge the generosity of the anonymous Danish and Dutch farmers and research herds who allowed GHG sampling of their cows. The kind assistance of Dr Per Madsen and Dr Mahmoud Shirali with calculations for standard errors of correlations between gRFI and other traits. Dr Ghyslaine Schopen, Dr Sabine van Engelen, Dr Wijbrand Ouweltjes and Mr Martin Bjerring for their curatorship of the Dutch and Danish datasets and technical expertise. G.F. Difford benefited from an Erasmus-Mundus fellowship and a grant by the Innovation Fund Denmark project REMRUM, within the framework of the European Graduate School in Animal Breeding and Genetics. The authors would like to express gratitude to the EU COST-action METHAGENE network for the interesting discussions and input.

\section{References}

Aubry, A., and T. Yan. 2015. Meta-analysis of calorimeter data to establish relationships between methane and carbon dioxide emissions or oxygen consumption for dairy cattle. Anim. Nutr. 1:128-134. 
doi:10.1016/j.aninu.2015.08.015.

Beerda, B., W. Ouweltjes, L.B.J. Šebek, J.J. Windig, and R.F. Veerkamp. 2007. Effects of Genotype by Environment Interactions on Milk Yield, Energy Balance, and Protein Balance. J. Dairy Sci. 90:219-228. doi:10.3168/jds.S00220302(07)72623-1.

Breider, I.S., E. Wall, P.C. Garnsworhty, and J.E. Pryce. 2018. Genetic relationships between methane emission and milk yield, live weight and dry matter intake. Page in Proceedings of the World Congress on Genetics Applied to Livestock Production, 11.

CVB. 2008. Tabellenboek Veevoeding (Dutch Feed Table Booklet). Centraal Veevoeder Bureau, Lelystad, The Netherlands.

Difford, G.F., J. Lassen, and P. Løvendahl. 2016. Interchangeability between methane measurements in dairy cows assessed by comparing precision and agreement of two non-invasive infrared methods. Comput. Electron. Agric. 124:220-226. doi:10.1016/j.compag.2016.04.010.

van Engelen, S., H. Bovenhuis, P.P.J. van der Tol, and M.H.P.W. Visker. 2018. Genetic background of methane emission by Dutch Holstein Friesian cows measured with infrared sensors in automatic milking systems. J. Dairy Sci. 19. doi:10.3168/jds.2017-13441.

Falconer, D., and T. Mackay. 1996. Introduction to quantitative genetics (4th edn). Genet.

FAO. 2010. Greenhouse Gas Emissions from the Dairy Sector. A Life Cycle Assessment. Accessed December 5, 2017. http://www.fao.org/docrep/012/k7930e/k7930e00.pdf.

de Haas, Y., M.P.L. Calus, R.F. Veerkamp, E. Wall, M.P. Coffey, H.D. Daetwyler, B.J. Hayes, and J.E. Pryce. 2012. Improved accuracy of genomic prediction for dry matter intake of dairy cattle from combined European and Australian data sets.. J. Dairy Sci. 95:6103-12. doi:10.3168/jds.2011-5280.

de Haas, Y., J.J.J. Windig, M.P.L.P.L. Calus, J. Dijkstra, M. de Haan, a. Bannink, R.F.F. Veerkamp, M. De Haan, a. Bannink, and R.F.F. Veerkamp. 2011. Genetic parameters for predicted methane production and potential for reducing enteric emissions through genomic selection.. J. Dairy Sci. 94:6122-34. doi:10.3168/jds.2011-4439.

Hailemariam, D., G. Manafiazar, J. Basarab, F. Miglior, G. Plastow, and Z. Wang. 2016. Greenhouse gas emission related traits differ in RFI divergent lactating dairy cows. J. Anim. Sci. 94:191. doi:Https://doi.org/10.2527/jam2016-0394.

Huhtanen, P., E.H. Cabezas-Garcia, S. Utsumi, and S. Zimmerman. 2015. Comparison of methods to determine methane emissions from dairy cows in farm conditions. J. Dairy Sci. 98:3394-3409. doi:10.3168/jds.2014-9118.

Huttmann, H., E. Stamer, W. Junge, G. Thaller, and E. Kalm. 2009. Analysis of feed intake and energy balance of high-yielding first lactating Holstein cows with fixed and random regression models. Animal 3:181-188. doi:10.1017/S175173110800325X. 
Kennedy, B.W., J.H.J. Van Der Werf, and T.H.E. Meuwissent. 1993. Genetic and Statistical Properties of Residual Feed Intake' 3239-3250.

van Knegsel, A.T.M., G.J. Remmelink, S. Jorjong, V. Fievez, and B. Kemp. 2014. Effect of dry period length and dietary energy source on energy balance, milk yield, and milk composition of dairy cows. J. Dairy Sci. 97:1499-1512. doi:10.3168/jds.2013-7391.

Koenen, E.P.C., and R.F. Veerkamp. 1998. Genetic covariance functions for live weight, condition score, and dry-matter intake measured at different lactation stages of Holstein Friesian heifers. Livest. Prod. Sci. 57:67-77. doi:10.1016/S0301-6226(98)00159-6.

Lassen, J., and P. Løvendahl. 2016. Heritability estimates for enteric methane emissions from Holstein cattle measured using noninvasive methods. J. Dairy Sci. 99:1959-1967. doi:10.3168/jds.2015-10012.

Lassen, J., P. Løvendahl, and J. Madsen. 2012. Accuracy of noninvasive breath methane measurements using Fourier transform infrared methods on individual cows. J. Dairy Sci. 95:890-8. doi:10.3168/jds.2011-4544.

Lassen, J., J.R. Thomasen, R.H. Hansen, G.G.B. Nielsen, E. Olsen, P.R.. Stentebjerg, N.W.H. Hansen, and S. Borchersen. 2018. Individual measure of feed intake on in-house commercial dairy cattle using 3D camera system. Page in Proceedings of the World Congress on Genetics Applied to Livestock Production, 11., Auckland.

Li, B., B. Berglund, W.F. Fikse, J. Lassen, M.H. Lidauer, P. Mäntysaari, P. Løvendahl, D.J. Garrick, J.C.M. Dekkers, C.R. Baumrucker, M.J. VandeHaar, and Y. De Haas. 2017. Neglect of lactation stage leads to naive assessment of residual feed intake in dairy cattle.. J. Dairy Sci. 92:2270-2275. doi:10.3168/jds.201712775.

Lu, Y., M.J. Vandehaar, D.M. Spurlock, K.A. Weigel, L.E. Armentano, C.R. Staples, E.E. Connor, Z. Wang, N.M. Bello, and R.J. Tempelman. 2015. An alternative approach to modeling genetic merit of feed efficiency in dairy cattle. J. Dairy Sci. 98:6535-6551. doi:10.3168/jds.2015-9414.

Madsen, P. 2012. DMU trace, A program to trace the pedigree for a sub set of animals from a larger pedigree file.

Madsen, P., and J. Jensen. 2014. A user's guide to DMU, version 6, release 5.0. Cent. Quant. Genet. Genomics Dept. Mol. Biol. Genet. Univ. Aarhus Res. Cent. Foulum Box 50, 8830 Tjele Denmark.

Manzanilla-Pech, C.I. V, R.F. Veerkamp, R.J. Tempelman, M.L. van Pelt, K.A. Weigel, M. VandeHaar, T.J. Lawlor, D.M. Spurlock, L.E. Armentano, C.R. Staples, M. Hanigan, and Y. De Haas. 2016. Genetic parameters between feed-intakerelated traits and conformation in 2 separate dairy populations-the Netherlands and United States.. J. Dairy Sci. 99:443-57. doi:10.3168/jds.2015-9727.

Manzanilla Pech, C.I. V, R.F. Veerkamp, M.P.L. Calus, R. Zom, a van Knegsel, J.E. Pryce, and Y. De Haas. 2014. Genetic parameters across lactation for feed 
intake, fat- and protein-corrected milk, and liveweight in first-parity Holstein cattle.. J. Dairy Sci. 97:5851-5862. doi:10.3168/jds.2014-8165.

Moraes, L.E., E. Kebreab, a. B. Strathe, J. Dijkstra, J. France, D.P. Casper, and J.G. Fadel. 2015. Multivariate and univariate analysis of energy balance data from lactating dairy cows. J. Dairy Sci. 98:4012-4029. doi:10.3168/jds.2014-8995.

Nielsen, H.M., N.C. Friggens, P. Løvendahl, J. Jensen, and K.L. Ingvartsen. 2003. Influence of breed, parity, and stage of lactation on lactational performance and relationship between body fatness and live weight. Livest. Prod. Sci. 79:119-133. doi:10.1016/S0301-6226(02)00146-X.

Shirali, M., V.H. Nielsen, S.H. Moller, and J. Jensen. 2015. Longitudinal analysis of residual feed intake in mink using random regression with heterogeneous residual variance. Animal 1597-1604. doi:10.1017/S1751731115000956.

Shirali, M., A.B. Strathe, T. Mark, B. Nielsen, and J. Jensen. 2017. Joint analysis of longitudinal feed intake and single recorded production traits in pigs using a novel Horizontal model. J. Anim. Sci. 0:0. doi:10.2527/jas.2016.0606.

Sloniewski, K., I.L. Mao, J. Jensen, and P. Madsen. 2005. Changes in body weight and frame and its genetic variation during the productive life of dairy cows. Acta Agric. Scand. A Anim. Sci. 55:128-136. doi:10.1080/09064700500478564.

Sondergaard, E., M.K. Sorensen, I.L. Mao, and J. Jensen. 2002. Genetic parameters of production, feed intake, body weight, body composition, and udder health in lactating dairy cows. Livest. Prod. Sci. 77:23-34.

Veerkamp, R.F., J.K. Oldenbroek, H.J. Van der Gaast, and J.H.J. Van Der Werf. 2000. Genetic Correlation Between Days Until Start of Luteal Activity and Milk Yield , Energy Balance, and Live Weights. J. Dairy Sci. 83:577-583. doi:10.3168/jds.S0022-0302(00)74917-4.

Wallén, S.E., M. Lillehammer, and T.H.E. Meuwissen. 2017. Strategies for implementing genomic selection for feed efficiency in dairy cattle breeding schemes. J. Dairy Sci. 100:6327-6336. doi:10.3168/jds.2016-11458.

Werf, J.H.J. Van Der. 2017. Teaching Software Used for Quantitative Genetics at UNE. Accessed June 5, 2017. https://jvanderw.une.edu.au/software.htm.

Wu, L., P.W.G.G. Koerkamp, and N. Ogink. 2018. Uncertainty assessment of the breath methane concentration method to determine methane production of dairy cows. J. Dairy Sci. 101:1554-1564. doi:10.3168/jds.2017-12710.

Zetouni, L., M. Kargo, E. Norberg, and J. Lassen. 2018. Genetic correlations between methane production and fertility, health, and body type traits in Danish Holstein cows. J. Dairy Sci. 101:1-8. doi:10.3168/jds.2017-13402.

Zom, R.L.G., G. André, and A.M. van Vuuren. 2012. Development of a model for the prediction of feed intake by dairy cows: 1 . Prediction of feed intake. Livest. Sci. 143:43-57. doi:10.1016/j.livsci.2011.08.014. 



\title{
Chapter 5
}

\section{Host genetics and the rumen microbiome jointly associate with methane emissions in dairy cows}

\author{
Gareth Frank Difford ${ }^{1,2}$, Damian Rafal Plichta ${ }^{3,4}$, Peter Løvendahl ${ }^{1}$, \\ Jan Lassen ${ }^{1,5}$, Samantha Joan Noel ${ }^{6}$, Ole Højberg ${ }^{6}$, André-Denis G. Wright ${ }^{7}$, \\ Zhigang Zhu ${ }^{6}$, Lise Kristensen ${ }^{1}$, Henrik Bjørn Nielsen ${ }^{3,4}$, Bernt Guldbrandtsen ${ }^{1}$, \\ Goutam Sahana ${ }^{1}$
}

1 Department of Molecular Biology and Genetics, Faculty of Science and Technology, Aarhus University, PO Box 50, DK-8830 Tjele, Denmark; ${ }^{2}$ Animal Breeding and Genomics Centre, Wageningen University, P.O. Box 338, $6700 \mathrm{AH}$ Wageningen, The Netherlands; ${ }^{3}$ Center for Biological Sequence Analysis, Dept. of Systems Biology, Technical University of Denmark, DK-2800 Kongens Lyngby, Denmark; ${ }^{4}$ Clinical-Microbiomics A/S, DK-2100 Copenhagen, Denmark; ${ }^{5}$ Viking Genetics, Ebeltoftvej 16, Assentoft, 8960 Randers, Denmark; ${ }^{6}$ Department of Animal Science, Aarhus University, Blichers Allé 20, Box 50, 8830, Tjele, Denmark;

${ }^{7}$ School of Animal and Comparative Biomedical Sciences, University of Arizona, 1177 E. Lowell Street, Tucson, AZ, USA 85721. 



\section{Abstract}

Background. Cattle and other ruminants produce large quantities of methane ( 110 million metric tonnes per annum), which is a potent greenhouse gas affecting global climate change. Methane $\left(\mathrm{CH}_{4}\right)$ is a natural by-product of gastro-enteric microbial fermentation of feedstuffs in the rumen and contributes to $6 \%$ of total $\mathrm{CH}_{4}$ emissions from anthropogenic-related sources. The extent to which the host genome and rumen microbiome influence $\mathrm{CH}_{4}$ emission is not yet well known.

Results. This study confirms individual variation in $\mathrm{CH}_{4}$ production was influenced by individual host (cow) genotype, as well as the host's rumen microbiome composition. Abundance of a small proportion of bacteria and archaea taxa were influenced to a limited extent by the host's genotype and certain taxa were associated with $\mathrm{CH}_{4}$ emissions. However, the cumulative effect of all bacteria and archaea on $\mathrm{CH}_{4}$ production was $13 \%$, the host genetics (heritability) was $21 \%$ and the two are largely independent.

Conclusion. This study demonstrates variation in $\mathrm{CH}_{4}$ emission is likely not modulated through cow genetic effects on the rumen microbiome. Therefore, the rumen microbiome and cow genome could be targeted independently, by breeding low methane-emitting cows and in parallel, by investigating possible strategies that target changes in the rumen microbiome to reduce $\mathrm{CH}_{4}$ emissions in the cattle industry.

Key words: Host microbe interaction, Methane emission, Microbiability, Ruminotypes 



\subsection{Introduction}

Methane $\left(\mathrm{CH}_{4}\right)$ is a potent greenhouse gas (GHG) with a climate change potential 32 times greater than carbon dioxide $\left(\mathrm{CO}_{2}\right)$ (Holmes et al., 2013) and an atmospheric half-life of 12 years, which is substantially shorter than $\mathrm{CO}_{2}$ (>100 years) (IPCC, 2014). Therefore, reducing $\mathrm{CH}_{4}$ emissions from anthropogenic-related sources has been identified as a key area for mitigating climate change with immediate effects (Gerber et al., 2013; IPCC, 2014). Livestock accounts for $14.5 \%$ of anthropogenic-related $\mathrm{GHG}$ emissions and enteric $\mathrm{CH}_{4}$ emissions from ruminants accounts for 5.8\% (Gerber et al., 2013). Furthermore, $\mathrm{CH}_{4}$ emissions from livestock is predicted to markedly increase due to an expected doubling in the global milk and meat demand by 2050 (Alexandratos et al., 2006).

Ruminants, the most widespread livestock species, can digest a wide variety of high fiber feedstuffs due to the distinct microbiome in their rumen. Methane is a natural by-product of gastro-enteric fermentation of high fiber plant biomass by microbial enzymatic activity in the rumen (Hill et al., 2016). Bacteria, protozoa, and fungi in the rumen produce $\mathrm{CO}_{2}$ and hydrogen $\left(\mathrm{H}_{2}\right)$, which are converted to $\mathrm{CH}_{4}$, primarily by archaea known as methanogens. Approximately $99 \%$ of $\mathrm{CH}_{4}$ emitted from cattle is released in the breath by eructation and respiration(Janssen and Kirs, 2008). The emission of $\mathrm{CH}_{4}$ is also a crucial pathway for maintaining $\mathrm{H}_{2}$ balance and ruminal $\mathrm{pH}$, as the optimal conditions for anaerobic fermentation by the rumen microbial community is limited to a narrow range of partial pressure of $\mathrm{H}_{2}$ and $\mathrm{pH}$ (McAllister and Newbold, 2008). Hydrogenaseexpressing bacteria convert metabolic hydrogen from anaerobic fermentation into $\mathrm{H}_{2}$ which is then converted to $\mathrm{CH}_{4}$ via methanogenesis (McAllister and Newbold, 2008). Furthermore, emitted $\mathrm{CH}_{4}$ has a caloric value and represents a 2-12\% net loss of a cow's gross energy intake (Johnson and Johnson, 1995; Yan et al., 2010). Consequently, cattle and other ruminants with increased efficiency to digest high fiber feedstuffs but reduced $\mathrm{CH}_{4}$ production could in principal benefit the global climate and concurrently improve the profitability and sustainability of cattle production.

Mitigation to decrease $\mathrm{CH}_{4}$ production by cattle to date has been largely unsuccessful, as the available measures are temporary and not cumulative. Large international research approaches target the rumen microbial communities through feed additives (chemical or biological), feed formulations, and anti-methanogen vaccines (Moss et al., 2000). However, rumen microbial species rapid adaptation to changes in the substrate results in resistance to treatments and $\mathrm{CH}_{4}$ production returns to pre-treatment levels (Hristov et al., 2013). Conversely, rumen 
transplantation studies (transfaunation) show that the rumen bacterial community recovered to near pre-transfaunation composition after a short period of time (Weimer et al., 2010). This indicated the existence of a degree of host influence on rumen microbial composition(Weimer et al., 2010). Host genotype in cattle was reported to explain inter-animal differences in $\mathrm{CH}_{4}$ production (Donoghue et al., 2016; Lassen and Løvendahl, 2016) and the rumen microbial community influenced $\mathrm{CH}_{4}$ production (Roehe et al., 2016). However, empirical evidence linking the host's genetic influence over the rumen microbial community and $\mathrm{CH}_{4}$ production is rather limited (Roehe et al., 2016).

A promising strategy is genetic selection for low $\mathrm{CH}_{4}$ emitting cows, as it is sustainable, persistent, and cumulative over subsequent generations. Whether the host influences the rumen microbial community, and consequently $\mathrm{CH}_{4}$ production, or the two interact to affect $\mathrm{CH}_{4}$ production is currently unknown. If reduced $\mathrm{CH}_{4}$ production in cows is a consequence of poor symbiosis with rumen microbes and thus fiber digestibility, there is a risk selection for reduced $\mathrm{CH}_{4}$ production will act against the very symbiosis which has aided ruminants and rumen microbes' coexistence. Thus, the extent to which the rumen microbiome is under the host genetic influence needs elucidation. If host genetics impose a strong influence on rumen microbial composition, traits influenced by rumen microbes could be improved by using rumen microbial composition as indicator traits in selection. However, should host genetics impose a strong influence on rumen microbial composition and selection for $\mathrm{CH}_{4}$ production proceed without cognizance of rumen microbial composition, there is a risk of unfavorable correlated responses in rumen microbial composition.

We hypothesized that: 1 ) the relative composition of the microbiome in the rumen is heritable i.e. controlled by host genome and 2 ) variation in methane emission from rumen is influenced by both the cow genome and rumen microbial content.

\subsection{Materials and Methods}

\subsubsection{Experimental design}

All handling of animals was conducted according to a protocol approved by The Animal Experiments Inspectorate, Danish Veterinary and Food Administration, Ministry of Environment and Food of Denmark (Approval number 2016-15-020100959).

Methane emissions from 750 lactating Holstein cows in five commercial herds were recorded using a portable Fourier Transform Infrared unit (FTIR; Gasmet 
DX-4000, Gasmet Technologies, Helsinki, Finland)(Lassen et al., 2012; Lassen and Løvendahl, 2016) and one research herd using a permanently installed nondispersive infrared (NDIR; Guardian NG/Gascard Edinburgh Instruments Ltd., Livingston, UK) (Difford et al., 2016a). Briefly, the FTIR and NDIR equipment were installed within the feed bins of automated milking systems (AMS) in each commercial herd with the FTIR for seven consecutive days and the NDIR were permanently placed in the research herd. The FTIR and NDIR device inlets were installed in the AMS feed bins and methane $\left(\mathrm{CH}_{4}\right)$ and carbon dioxide $\left(\mathrm{CO}_{2}\right)$ gas concentrations (ppm) sampled continuously every $5 \mathrm{~s}$ and $1 \mathrm{~s}$, respectively(Lassen et al., 2012; Difford et al., 2016a). Cows were milked individually in the AMS and milked on average $(18.2 \pm 3.4)$ times during the seven-day period, for durations ranging from five minutes to 12.2 minutes. Mean $\mathrm{CH}_{4}$ and $\mathrm{CO}_{2}$ gas concentrations were corrected for environmental factors, including diurnal variation and day to day differences using a linear mixed model following (Difford et al., 2016a) to approximate daily averages. Measurement stability was assessed by model repeatability and used as data quality control. All herds practiced indoor feeding strategies with ad libitum access to feed and water. A total mixed ration (TMR) was provided, consisting primarily of rolled barley, corn silage, grass clover silage, rapeseed meal, soybean meal and up to $3 \mathrm{~kg}$ of concentrate supplement given during milking. Although all commercial herds employed a standardized TMR recipe, ingredient-specific differences among farms were expected to contribute to differences in TMR dietary values over herds.

Weekly mean values for milk yield and body weight were combined with weekly gas concentrations, as described in (Lassen et al., 2012) and applied to predict cow heat production(CIGR, 2002). During each week of $\mathrm{CH}_{4}$ and $\mathrm{CO}_{2}$ recording at different herds, milk samples were collected to estimate milk fat and protein percentages. Cow fat and protein corrected milk yield (FPCM) was estimated following the national recording scheme (RYK, Skejby, Denmark) (Sjaunja et al., 1991). Methane production (L/day) was estimated using the $\mathrm{CH}_{4}$ to $\mathrm{CO}_{2}$ ratio and predicted $\mathrm{CO}_{2}$ emission (Pedersen et al., 2008) from the conversion of cow heat production units to $\mathrm{CO}_{2}$ production, following (Madsen et al., 2010a) and then converted to $(\mathrm{g} / \mathrm{d})$ using $\mathrm{CH}_{4}$ density at standard temperature and pressure.

Holstein cow pedigree records were traced in the Danish national database (NAV, Skejby, Denmark) as far back as 1926 to construct a pedigree-based relationship matrix for the quantitative genetic analysis.

\subsubsection{Sampling rumen liquid fraction}


Immediately following the $\mathrm{CH}_{4}$ recording period, rumen content samples were drawn from individual cows by oral insertion of the probe "Flora Rumen Scoop" (Geishauser et al., 2012). Approximately $40 \mathrm{~mL}$ of the liquid fraction containing particulate matter was drawn from the rumen using this method. Trained technicians conducted the sampling to ensure correct probe insertion into the rumen following a previously established protocol (Geishauser et al., 2012), recognizing that the location of the flora rumen scoop may differ somewhat from sampling to sampling. The entire "Flora Rumen Scoop" was rinsed vigorously between animal sampling to minimize cross-contamination. Samples were labeled, immediately placed on ice, and transferred to the laboratory within two hours for further processing. Each $40 \mathrm{~mL}$ sample was mixed vigorously, a subsample of $1.2 \mathrm{~mL}$ rumen fluid was collected, and transferred to a $1.5 \mathrm{~mL}$ vial, then snap frozen in liquid nitrogen, before storing at $-80{ }^{\circ} \mathrm{C}$, until shipped on dry ice to a commercial sequencing company (GATC Biotech, Constance, Germany) for analysis.

\subsubsection{DNA extraction, bacterial and archaeal 16S rRNA gene amplification, and sequencing}

DNA extraction, sequencing library construction and sequencing were conducted by GATC Biotech (Constance, Germany). Rumen samples were defrosted at $4{ }^{\circ} \mathrm{C}$ overnight and vortexed until homogenous. A representative sample $(500 \mu \mathrm{l})$ containing rumen liquid and solids was used for DNA isolation using the Qiagen QIAamp stool kit (Valencia, United States of America) following the manufacturer's instructions, modified for the larger sample size(Johnson et al., 2005).

Two primer sets were used to create 16S rRNA libraries, one set for all bacteria and one set for all archaea. Universal bacterial 16S rRNA gene primers (covering the V1-V3 variable regions) 27F: 5'-AGAGTTTGATCCTGGCTCAG-3' and 534R: 5'-ATTACCGCGGCTGCTGG-3' were used to generate the bacterial amplicon libraries (expected amplicon size 508 bp)(Ward et al., 2012). Universal archaeal 16S rRNA gene primers (covering the V4-V6 variable regions) S-D-Arch-0519-a-S-15 5'CAGCMGCCGCGGTAA-3' and S-D-Arch-1041-a-A-18 5'-GGCCATGCACCWCCTCTC-3' were used to generate the archaeal amplicon libraries (expected amplicon size 542 bp) (Klindworth et al., 2013). Following protocols standardized by GATC Biotech, PCR amplifications were conducted with GoTaq Green polymerase (Promega, Madison, USA) with $30 \mathrm{PCR}$ cycles and a $60^{\circ} \mathrm{C}$ annealing temperature for the archaeal amplicon libraries and 25 PCR cycles with a $60{ }^{\circ} \mathrm{C}$ annealing temperature for the bacterial amplicon libraries. The $16 \mathrm{~S}$ rRNA amplicons were purified using the Axyprep Fragment Select bead purification system (Axygen Biosciences, New York, USA), according to the manufacturer's instructions. The size and purity of the PCR product 
was verified on a Fragment Analyzer using a High Sensitivity NGS Fragment Analysis Kit (Advanced Analytical Technologies, Ankeny, USA). Multiplex indices and Illumina overhang adapters were added to both amplicon libraries in a second PCR amplification round (six cycles), followed by Fragment Analyzer analysis to confirm the correct size of the amplicons (Advanced Analytical Technologies, Ankeny, USA). Ninety-six libraries were pooled in equimolar concentrations and sequenced with an Illumina sequencing instrument using the $300 \mathrm{bp}$ paired-end read mode, according to the manufacturer's specifications. Approximately half the samples were run using the illumina MiSeq platform and half with the HiSeq platform. The $300 \mathrm{bp}$ paired end protocol was adapted to HiSeq by GATC Biotech. The specific samples entered into sequencing batches within each sequencing platform were recorded for subsequent significance testing to examine possible differences between sequencing batches and sequencing platforms in statistical analyses.

\subsubsection{Bacterial and archaeal 16S rRNA gene sequence processing and OTU table construction.}

Bacterial and archaeal sequence reads underwent quality control, processing and were clustered into operational taxonomic units (OTUs) using the LotuS pipeline (Hildebrand et al., 2014) with the following options: Sequence truncation length and minimum sequence length after barcode and primer removal was $230 \mathrm{bp}$. Minimum average sequence quality score was 27 , the maximum number of ambiguous bases was 0 , maximum homonucleotide run was set to 8 . Sequences were filtered away if any of the $50 \mathrm{bp}$ segments in a sequence had average scores below 25 or if the expected number of errors exceeded 2.5 in the binomial error model. The low-quality sequence ends were trimmed by applying a sliding window quality filter with a width of $20 \mathrm{bp}$ and a minimum average quality score within the window of 25 . Sequences were truncated if the probabilistic accumulated error exceeded 0.75 . The reads were de-replicated and sequences with a minimum of 10 replicates were retained for OTU clustering within the Lotus pipeline. Sequence pairs were merged with Flash (Magoč and Salzberg, 2011) and clustered into OTUs based on sequence similarity (97\%) with UPARSE(Edgar, 2013) and chimeric sequences removed with UCHIME reference-based chimera detection (Edgar et al., 2011). Representative sequences from each OTU were aligned with ClustalO (Sievers et al., 2011) and a phylogenetic tree built with FastTree2(Price et al., 2010). Representative sequences, the OTU table, and phylogenetic trees were transferred to QIIME (version 1.9.0)(Caporaso et al., 2010), where further analyses were performed. Taxonomy was assigned to each OTU using the RDP classifier with a confidence level of 0.8(Wang et al., 2007) using greengenes (gg_13_8_otus) as the reference database. 
Unclassified OTUs and OTUs classified to non-target kingdoms were filtered from the OTU tables, i.e. only OTUs classified as k_Bacteria were maintained for the bacterial primer set and similarly OTUs classified as k_Archaea maintained for the archaeal primer set. Finally, samples with $<50,000$ sequences were removed and OTUs containing $<10$ sequences were filtered out of the OTU table.

\subsubsection{Statistical models: Additive Genetic Variance Estimation}

The linear mixed model utilized to estimate additive genetic variance is as follows:

$$
y_{i j k l}=\mu+h_{j}+p_{k}+b_{1}\left(\operatorname{dim}_{l}\right)+b_{2}\left(e^{-0.065 \times \operatorname{diml}}\right)+a_{i}+e_{i j k l}
$$

where $y_{i j k l m}$ is the observed phenotype, e.g. methane emission in grams/day; $\mu$ is the model intercept; $h_{j}$ is the herd fixed effect ( $\mathrm{j}=6$ levels); $p_{k}$ is the parity fixed effect ( $\mathrm{k}=4$ levels); $b_{1}$ is days in milk fixed regression coefficient ( $\operatorname{dim} \mathrm{I}=$ 1-350); and $b_{2}$ is the Wilmink term fixed regression coefficient generated on dim to account for non-linearity in early lactation (Wilmink, 1987). Term $a_{i}$ is individual animal random additive genetic effects $\sim \operatorname{NID}\left(0, A \sigma^{2}{ }_{a}\right)$, where $\sigma^{2}{ }_{a}$ is the additive genetic variance and $\mathbf{A}$ is the pedigree derived numerator relationship matrix ( $i=750$ animals); and $\mathrm{e}_{i j k l}$ is the random residual $\sim \operatorname{NID}\left(0, \sigma^{2} \mathrm{e}\right)$, where $\sigma^{2}{ }_{\mathrm{e}}$ is the error variance. The additive host genetic effects on relative rumen bacterial and archaeal abundance was estimated applying the same general equation as model 1 above, with the addition of the sequencing batch fixed effects nested within the sequencing platforms (11 levels). The analyses were performed using the DMU software (Madsen et al., 2010b).

\subsubsection{Statistical models: Rumen Microbial Variance Estimation}

The relationship among cows based on their similarity in rumen microbiome composition was estimated by constructing a microbial relationship matrix (M) inspired by Ross et al. (2012), where a metagenomic relationship matrix was created from a vector of aligned rumen microbial contig sequences. The matrix was computed as a variance-covariance matrix from rumen bacterial and archaeal abundance as follows:

$$
\boldsymbol{M}=\frac{X \boldsymbol{X}^{\prime}}{n}
$$

where $\mathbf{X}$ is the matrix of natural log transformed bacterial and archaeal relative abundance for all animals and $\mathrm{n}$ is the number of bacterial and archaeal OTUs within the population. Matrix $\mathbf{X}$ is derived from OTU tables after filtering out OTUs, which were absent from more than $50 \%$ of the samples and were homogeneous. The matrix $\mathbf{X}$ was subsequently scaled and centered within sequencing instrument 
(Miseq or Hiseq) to account for differences between instruments and recombined into a single matrix prior to the calculation of $\mathbf{M}$.

The variance explained by microbial composition was estimated employing models similar to equation 1 , where the random effect of $m_{i}$ was fit separately and jointly with $a_{i}$, i.e. random additive genetic effects. Term $m_{i}$ is the rumen microbial effect for the $i^{\text {th }}$ animal $\sim \operatorname{NID}\left(0, M \sigma^{2}{ }_{m}\right)$, where $\sigma^{2}{ }_{m}$ is the rumen microbial variance and $\mathbf{M}$ is the microbial relationship matrix, described in (2), i= 750 animals.

\subsubsection{Association between rumen bacterial and archaeal OTU's and host methane emission}

The association between the relative abundance of each bacterial and archaeal OTU abundance with host methane production was conducted using linear mixed model analyses as proposed by Yu et al. (2006), with the exception that OTU effects were estimated in place of allele substitution effects for genetic variants, as performed in genetic association analysis. The significance threshold was calculated using a Benjamini Hochberg false discovery rate correction for multiple testing. There were 189 archaeal and 3894 bacterial OTUs tested, and the microbiome wide significant threshold at FDR of $15 \%$ was in $-\log _{10}(P)$ scale 2.17 .

\subsubsection{Microbial Community Analysis}

A principal coordinate analysis (PoCA) was conducted to investigate similarities or dissimilarities using a distance matrix from the archaeal and bacterial rumen community composition. The Bray-Curtis coefficient was employed separately for the archaeal and bacterial OTU tables to create sample-summary matrices, which were further explored using non-metric multidimensional scaling (NMDS)(Bray and Curtis, 1957). The effects of environmental and genetic parameter effects on community structures were evaluated using the following model:

$$
y_{i j k l}=\mu+s b_{j}+p_{k}+b_{1}\left(\operatorname{dim}_{1}\right)+b_{2}\left(e^{-0.065 \times \operatorname{diml} l}\right)+a_{i}+e_{i j k l}
$$

where $y_{i j k l m}$ is the observed phenotype, e.g. PCOA 1 and PCOA2 for bacteria or archaea; $\mu$ is the model intercept; $s b_{j}$ is the sequencing batch run fixed effect nested within the sequencing platform ( $\mathrm{j}=11$ levels); $p_{k}, b_{1}, \operatorname{dim}_{l}, b_{2}, a_{i}$, and $\mathrm{e}_{i j k l}$ are as described in equation (1). Additive genetic effects of host could not be detected from the bacterial and archaeal community structures for PCOA 2 and only herd environmental effects were significant. The distribution of a priori defined high and low emitters along PCoA1 was tested for bacterial and archaeal community structures, respectively by means of Mann-Whitney tests.

\subsection{Results}




\subsubsection{Variation in methane emission and its heritability in lactating dairy cattle}

Methane concentration in the exhalation-breath of 750 lactating Holstein dairy cows from farmer herds in Denmark was measured individually during automated machine milking for one week. Within-week methane measurements had a high repeatability coefficient of $0.70 \pm 0.02$ (estimate $\pm \mathrm{SE}$ ). Estimated average daily methane emission was $395.8 \pm 63.5 \mathrm{~g} / \mathrm{d}$ (mean $\pm \mathrm{SD}$ ), which was consistent with reports from the literature(Lassen et al., 2016). Considerable variation in estimated $\mathrm{CH}_{4}$ emission among cows was observed. The top $10 \%$ methane emitting cows $(519.28 \pm 28.5 \mathrm{~g} / \mathrm{d})$ had a $41 \%$ mean difference from the low $10 \%$ emitting cows (303.8 $\pm 11.9 \mathrm{~g} / \mathrm{d}$ ) (Supplemental Fig S5.1). Results from linear mixed model with pedigree records indicated methane emission was moderately heritable, $0.19 \pm 0.09$ (heritability coefficient, $\mathrm{h}^{2} \pm \mathrm{S}$.E), which was consistent with previous findings in lactating Holstein cows in Denmark (Lassen and Løvendahl, 2016).

\subsubsection{Rumen bacterial and archaeal community composition}

We identified 3,894 bacterial operational taxonomic units (OTUs, $\geq 97 \%$ identity) and 189 archaeal OTUs, which were present in a minimum of $50 \%$ of the cow samples ( $50 \%$ threshold maximizes the variation in a binary trait i.e. presence or absence). Taxonomic classification revealed generic bacterial and archaeal composition. The predominant bacterial phylum found was Bacteroidetes $72.2 \% \pm$ 6.5 (mean \pm SD), followed by Firmicutes $(18.3 \% \pm 5.6)$ and Tenericutes $(2.8 \% \pm 1.0)$. Absconditabacteria, Spirochaetes, Fibrobacteres, and Proteobacteria each comprised less than $2 \%$, and another 20 phyla constituted $1 \%$ of all sequence reads.

The archaeal community was dominated by two families, Methanobacteriaceae and Methanomassiliicoccaceae $(35 \% \pm 22.1)$ of the orders Methanobacteriales $(64.2 \% \pm 22.2$; mean \pm SD) and the recently proposed order Methanomassiliicoccales and class Thermoplasmata (lino et al., 2013), respectively. The remaining archaeal community was comprised of 10 families, which were low in abundance, cumulatively accounting for less than $1 \%$ of all archaeal sequence reads.

\subsubsection{Additive genetic variance estimates of rumen microbiota}

OTU abundance and OTU abundance collapsed at genus and family levels were used as microbial phenotypes. The heritability thereof was estimated using a linear mixed model with pedigree records (known as 'animal models'), which partitions total variance into additive genetic and environmental variance(Henderson, 1975). We calculated 95\% confidence intervals for OTU $\mathrm{h}^{2}$ estimates and found for $6 \%$ of bacterial and $12 \%$ of archaeal OTUs, the estimates 
were significantly higher than zero $(P<0.05)$, ranging from $16-44 \%$ (Fig. 5.1 ) and 18 - 33\% (Fig. 5.2), respectively. Due to the high number of independent tests, we calculated false discovery rate (FDR) corrected $P$ - values for $h^{2}$ estimates with a FDR threshold of $15 \%$ (Supplementary Table 5.1).

Heritability of bacterial and archaeal abundance was further estimated at the genus level. In total eight bacterial genera out of 144 showed significant $h^{2}$ estimates ranging from 0.17 to 0.25 (Table 5.1). Only a single archaeal genus, Methanobrevibacter, had a $\mathrm{h}^{2}$ estimate significantly different from zero $(0.22 \pm 0.09)$. However, Methanosphaera and Methanomicrococcus might also be under host additive genetic control with heritability estimates approaching significance thresholds (Table 5.1).

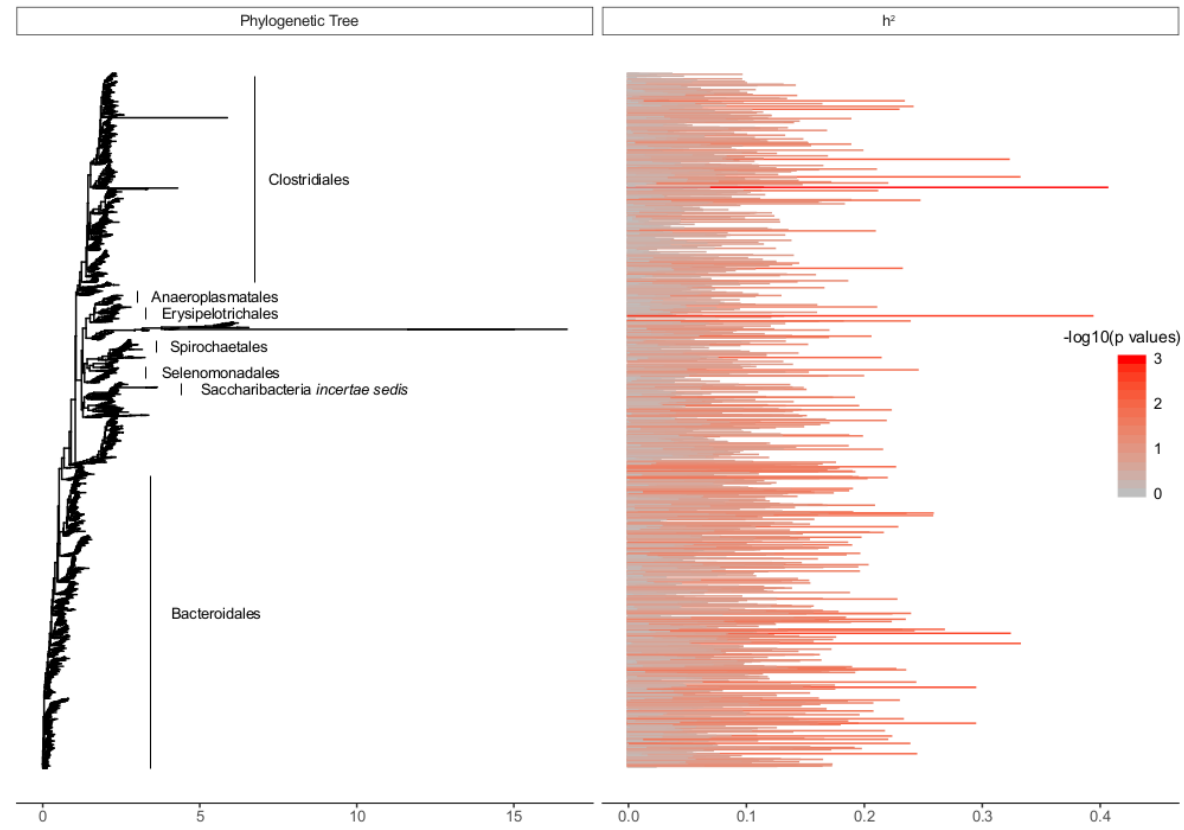

Figure 5.1 Phylogeny of 3,894 rumen bacterial OTU. Branch lengths represent substitution number per site calculated by FastTree2(81). Heritability estimates $\left(\mathrm{h}^{2}\right)$ for each OTU abundance are plotted with a horizontal bar and colored by taxonomic group classification. 


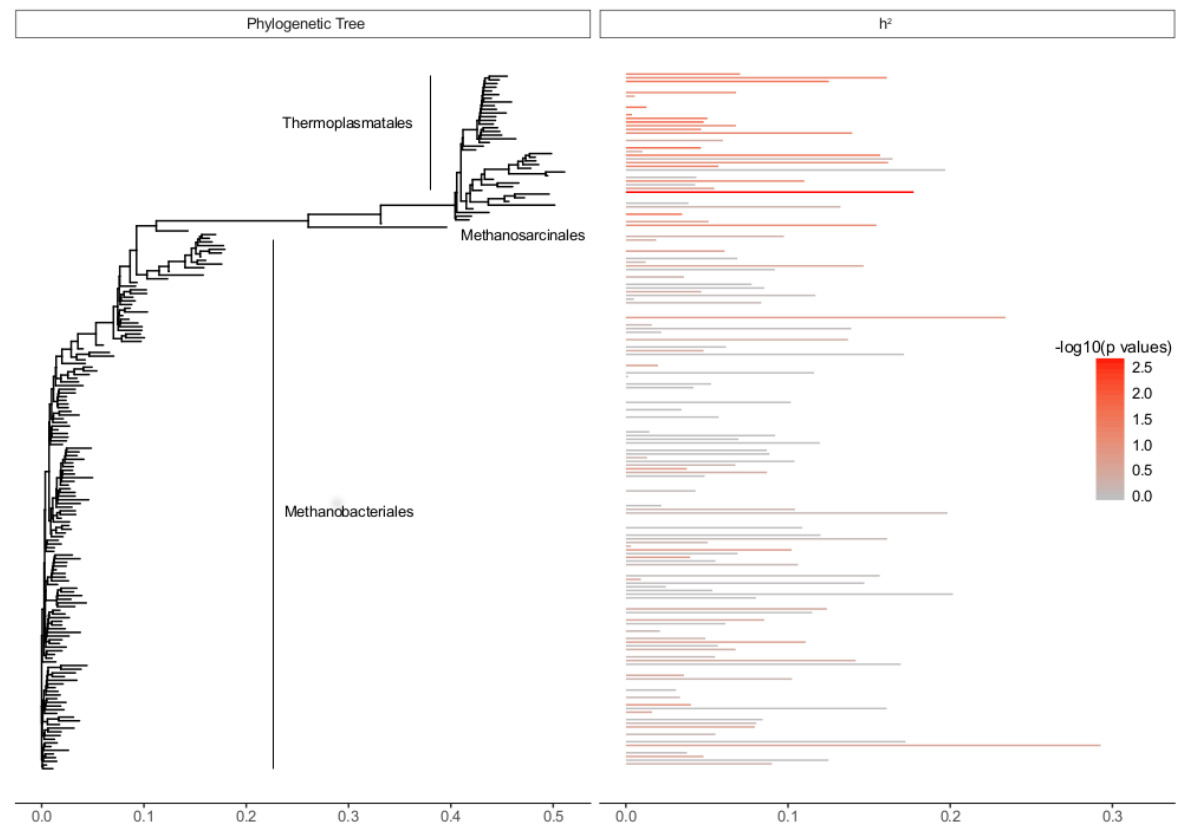

Figure 5.2 Phylogeny of 189 rumen archaeal OTU abundance. Branch lengths represent substitution number per site calculated by FastTree2(81). Heritability estimates $\left(\mathrm{h}^{2}\right)$ for each OTU abundance is plotted with a horizontal bar and colored by taxonomic group classification.

\subsubsection{Association between microbiota abundance and methane production}

Associations between relative bacterial and archaeal OTUs, genera abundance, and host $\mathrm{CH}_{4}$ emissions were tested, while simultaneously controlling for environmental factors and familial structures common in livestock due to relatedness among study samples (Yu et al., 2006; Tsilimigras and Fodor, 2016). The OTU or genera log-transformed abundance present in $>50 \%$ of cows were fit as an explanatory variable in a linear mixed model for $\mathrm{CH}_{4}$ production. Numerous significant OTUs were detected but failed to pass the threshold for multiple testing (FDR $\leq 0.15)$ (Supplementary Table 5.1). This was a hypothesis-generating analysis and not directed at specific hypothesis testing therefore we reported the significance and FDR corrected values (Supplementary Table 5.1). Seven genera in total were detected, which exceeded the significance threshold at FDR of $15 \%$. The $-\log _{10} P$ values are plotted in Figure 5.3. 
Table 5.1 Estimated heritability $\left(\mathrm{h}^{2}\right)$ and P-value for the relative abundances of bacterial and archaeal genera.

\begin{tabular}{lllll}
\hline Genus & $\begin{array}{l}\text { Relative } \\
\text { abundance } \\
(\%)\end{array}$ & $h^{2} \pm \mathrm{SE}$ & $\begin{array}{l}\text { 95\% Confidence } \\
\text { Interval }\end{array}$ & $P$-value \\
\hline Bacteria & & & & \\
\hline Paludibacter & 0.01 & $0.25 \pm 0.10$ & $(0.05-0.45)$ & 0.015 \\
Unclassified & 0.01 & $0.25 \pm 0.09$ & $(0.04-0.41)$ & 0.08 \\
$\begin{array}{l}\text { Spirochaetaceae } \\
\text { R4-45b }\end{array}$ & 0.01 & $0.23 \pm 0.09$ & $(0.05-0.41)$ & 0.014 \\
$\begin{array}{l}\text { F16 } \\
\text { Unclassified }\end{array}$ & 0.8 & $0.22 \pm 0.09$ & $(0.04-0.40)$ & 0.018 \\
$\begin{array}{l}\text { Endomicrobia } \\
\text { Unclassified }\end{array}$ & 0.04 & $0.21 \pm 0.09$ & $(0.02-0.40)$ & 0.027 \\
Victivallaceae & 0.08 & $0.20 \pm 0.09$ & $(0.01-0.39)$ & 0.36 \\
$\begin{array}{l}\text { Unclassified } \\
\text { Proteobacteria }\end{array}$ & 0.02 & $0.19 \pm 0.09$ & $(0.01-0.37)$ & 0.042 \\
$\begin{array}{l}\text { Sporobacter } \\
\text { Archaea }\end{array}$ & 0.01 & $0.17 \pm 0.08$ & $(0.00-0.34)$ & 0.046 \\
\hline $\begin{array}{l}\text { Methanobrevibacter } \\
\text { Methanosphaera }\end{array}$ & 55.8 & $0.22 \pm 0.09$ & $(0.04-0.42)$ & 0.02 \\
Methanomicrococcus & 0.7 & $0.18 \pm 0.10$ & $(-0.00-0.36)$ & 0.055 \\
\hline & & $0.18 \pm 0.09$ & $(-0.02-0.38)$ & 0.08 \\
\hline
\end{tabular}




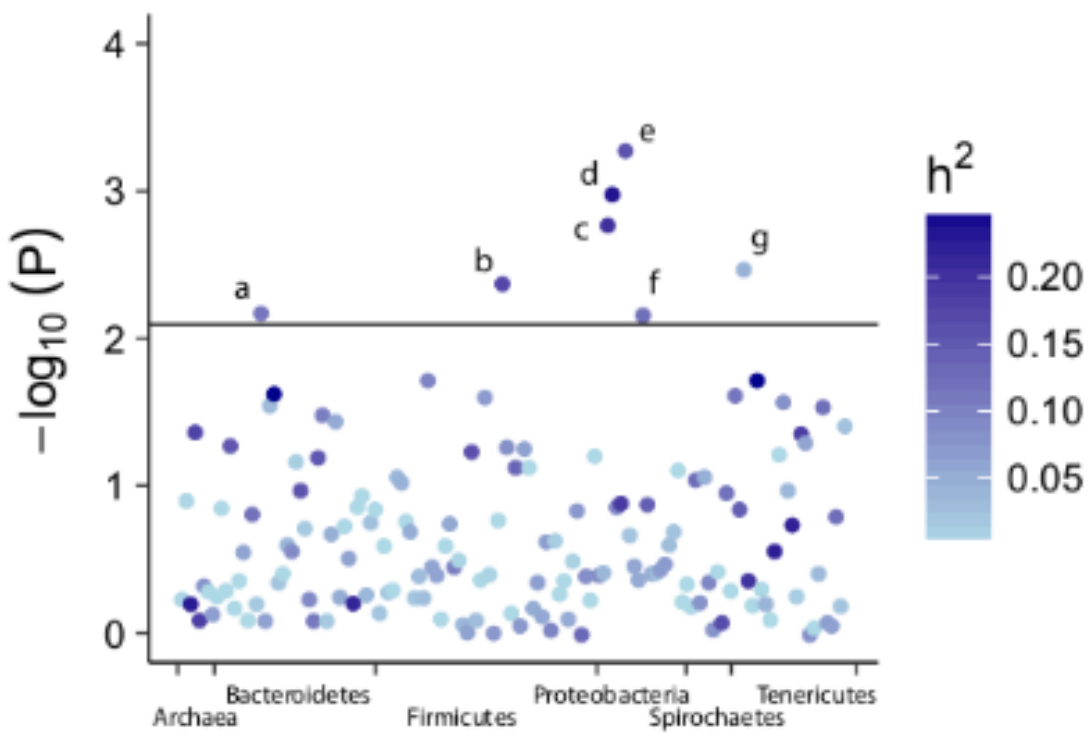

Figure 5.3. Manhattan plot of rumen bacterial and archaeal genera associations with methane emissions (g/day) colored by heritability $\left(h^{2}\right)$ estimates. Color gradient indicates genera $h^{2}$ with light blue $\left(h^{2}=0\right)$ ranging to dark blue $\left(h^{2}=0.30\right)$. The $y$-axis is $-\log _{10}(P)$ for association tests. The horizontal line represents the BenjaminiHochberg FDR 15\% for multiple testing significance thresholds. Genera above the threshold are a) Unclassified BS11 group; b) Sporobacter; c) Unclassified Victivallaceae; d) Unclassified Lentisphaeria; e) Unclassified Alphaproteobacteria; f) Unclassified Rickettsiales; and g) Sphaerochaeta.

\subsubsection{Variation in methane emission attributed to cows' additive genetics and rumen microbiome}

The relative proportion of variation in $\mathrm{CH}_{4}$ emissions due to rumen microbial composition and host additive genetic components was estimated individually and jointly using linear mixed models. Likelihood ratio tests revealed that fitting either random effect of rumen microbial composition or individual cow's polygenic component fitted the data significantly better than the null model i.e. including only fixed effects $(P<0.001)$. The model fitting both random effects (microbial composition and polygenic component) was significantly better $(P<$ 0.001 ) than models including only one random effect. The proportion of variance in $\mathrm{CH}_{4}$ production explained by the microbiome, here defined as microbiability $\left(\mathrm{m}^{2}\right)$, was calculated in analogy to the heritability $\left(h^{2}\right)$ (Difford et al., 2016b; Camarinha- 
silva et al., 2017). The contrast between the two intra-class correlation coefficients $\mathrm{h}^{2}$ and $\mathrm{m}^{2}$ with their respective standard errors for all models are depicted in Figure 5.5. The $\mathrm{m}^{2}$ of $\mathrm{CH}_{4}$ emission estimated individually was $0.15 \pm 0.08$ (estimate \pm S.E) and the $h^{2}$ estimated individually was $0.19 \pm 0.09$. Simultaneous estimates of both effects indicated slightly lower microbiability $(0.13 \pm 0.08)$, whereas $h^{2}$ exhibited a corresponding increase $(0.21 \pm 0.09)$ as compared to the preceding models fitting only one of the random effects. The combined microbial abundance and additive genetic effects were responsible for $\sim 34 \%$ of the total phenotypic variation in $\mathrm{CH}_{4}$ emissions.

\subsection{Discussion}

\subsubsection{Additive genetic variation in methane emissions and bacterial and archaeal taxa abundance}

The results of this study show that estimated $\mathrm{CH}_{4}$ emissions from a dairy cow were partially under the influence of host (cow's) additive genetics, which explained $19 \%$ of the total variation. Of the rumen bacterial OTUs, a modest $\sim 6 \%$ were associated with host additive genetics exhibiting significant heritability estimates (16 - 44\%) (Fig. 5.1). Similarly, only 12\% of archaeal OTU abundance was influenced by host additive genetics, with heritability estimates ranging from 18 33\% (Fig. 5.2). However, bacterial and archaeal heritability estimates failed to pass the threshold for multiple testing. Our test was conservative as a large number of taxa were analyzed with many OTUs having little or no influence by the host genome. Studies with larger sample sizes would give more reliable estimates of the heritabilities, especially for lower heritable OTUs. The $h^{2}$ estimates observed in this study were consistent with findings of intestinal microbiota in mice (Leamy et al., 2014; Org et al., 2015) and humans (Goodrich et al., 2014, 2016) and confirm that the majority of variation in rumen microbial abundance is due to factors other than host additive genetics (Rothschild et al., 2017). Interestingly, the patterns of $h^{2}$ with phylogeny differed between the bacteria and the archaea (Fig.5.1 and Fig.5.2). Heritable OTUs were distributed throughout the bacterial microbiome whereas archaea showed increased heritability within the Thermoplasmatales. This highlights the value of collating phylogeny with heritability estimates to focus research into possible mechanisms which predispose differential relative abundance of certain taxa across genetically related cows. The method employed to sample rumen contents is high-throughput and less invasive than surgical procedures, making it better suited to sampling large numbers of cows under commercial farm conditions. Large sample size is critical in genetic evaluations. However, it is important to note 
that the floral rumen scoop is inserted into an undefined portion of the rumen and likely samples the liquid phase. Recognizing that rumen microbial communities differ between liquid, solid and epimural phases (Kong et al., 2010), studies testing the repeatability and representativeness of sampling are needed.

\subsubsection{Associating rumen microbial taxa abundance with $\mathrm{CH}_{4}$ emissions}

We utilized linear mixed model analysis to test for associations between bacterial and archaeal OTUs, genera and families with estimated $\mathrm{CH}_{4}$ emissions, while concurrently accounting for effects such as parity, lactation stage, herd of origin and familial structure from the pedigree. Several bacterial genera associated with $\mathrm{CH}_{4}$ emission were detected. Out of these, four were found either to be affected by methane inhibitors or related to $\mathrm{H}_{2}$ production and other methanogenesis substrates. Three were moderately heritable $(0.17-0.25)$ (Supplementary Table 5.1). One of the identified bacteria, Sporobacter, with a mean relative abundance of $0.01 \%$ (Ruminococcaceae, Clostridiales, Firmicutes), belongs to a group with only a single cultured representative, Sporobacter termitidis, isolated from the intestine of wood-feeding termites (Nasutitemes lujae), also known for producing large amounts of $\mathrm{CH}_{4}$. However, when this isolate was co-cultured with an archaea species, Methanospirillum hungatei, $\mathrm{CH}_{4}$ was not produced. $S$. termitidis was found to generate acetate and methylsulfides, but not $\mathrm{H}_{2}$ or $\mathrm{CO}_{2}$, therefore interspecies $\mathrm{H}_{2}$ transfer did not occur and facilitate $\mathrm{CH}_{4}$ production (Grech-Mora et al., 1996). The recent discovery and proposed archaeal order Methanomassiliicoccales species found to utilize methylsulfides and $\mathrm{H}_{2}$ in methanogenesis(Borrel et al., 2014), provides a possible mechanism for methylsulfide producers to contribute to $\mathrm{CH}_{4}$ production when $\mathrm{H}_{2}$ producers are present. Methanomassilicoccales was prevalent in our samples (mean relative abundance 35\%); therefore, Sporobacter could potentially be contributing to $\mathrm{CH}_{4}$ production via a similar pathway.

We also detected Sphaerochaeta with a mean relative abundance of $0.01 \%$, associated with estimated $\mathrm{CH}_{4}$ production. Genomes from cultured Sphaerochaeta isolates revealed acetate, formate, ethanol, $\mathrm{H}_{2}$, and $\mathrm{CO}_{2}$ were potential fermentation end products (Caro-Quintero et al., 2012), many of which are methanogenic archaea substrates (Knapp et al., 2014). Furthermore, seed extracts from Perilla frutescens (Lamiaceae), a medicinal herb, decreased $\mathrm{CH}_{4}$ production in vitro from rumen samples of lactating dairy cows and decreased Sphaerochaeta abundance(Wang et al., 2016). Interestingly, Caro-Quintero et al. (2012) reported up to $40 \%$ of the genes from Spaerochaeta species were exchanged with members of Clostridiales (Firmicutes) and this inter-order-species horizontal gene transfer was 
most extensive in mesophilic anaerobic bacteria, such as the conditions found in termite and ruminant guts (Caro-Quintero and Konstantinidis, 2014). Here 16S rRNA gene sequencing is used as a proxy for metabolic activity but cannot account for inter-order-species horizontal gene transfer. Therefore, full metagenome sequence may have an advantage over the 16S rRNA gene to describe rumen microbial contents.

One bacterial genus detected in the present study, which is positively associated with estimated $\mathrm{CH}_{4}$ production, is classified in the yet uncultured BS11 gut group of the Bacteroidales (mean relative abundance 1.4\%). The relative abundance of the BS11 group reportedly decreased concomitantly with $\mathrm{CH}_{4}$ production by dietary methanogenic inhibitors, such as $P$. frutescens seed extract, mentioned previously(Wang et al., 2016), monesin and essential oil supplementation in dairy cattle (Boadi et al., 2004; Schären et al., 2017), and bromochloromethane in Japanese goats (Denman et al., 2015). Thus, supporting our finding of a positive association between BS11 and $\mathrm{CH}_{4}$ production. Solden et al. (2016) employed metagenomics sequencing and shotgun proteomics approaches to phylogenetically and metabolically resolve the BS11 gut group. They resolved two genera within the group and both exhibited multiple pathways to ferment hemicellulose, a capability previously unknown for BS11. The resulting fermentation end products included acetate, butyrate, propionate, $\mathrm{CO}_{2}, \mathrm{H}_{2}$ (Solden et al., 2016) the latter two being methanogenesis substrates. Genes encoding 'fucose sensing' pathways were found for only one of the proposed BS11 genera, offering a possible mechanism for interaction between genes in the BS11 group and the host (Roehe et al., 2016). However, further studies are needed to elucidate the links between $\mathrm{CH}_{4}$ inhibitors, host genes and $\mathrm{CH}_{4}$ production.

Due to the absence of cultured rumen bacteria isolates, an understanding of the metabolic function in many bacterial genera remains in its infancy. However, from the isolates discussed above, results suggested $\mathrm{CH}_{4}$ emissions depend on abundance of bacterial taxa that produce substrates for methanogenesis, such as $\mathrm{H}_{2}$. Remarkably, associations between archaeal relative abundance and estimated $\mathrm{CH}_{4}$ production were not detected in the present study, despite the knowledge that archaea are directly responsible for $\mathrm{CH}_{4}$ production. A meta-transcriptome study in sheep found archaeal transcription pathways and not simply abundance, contributed to inter-animal differences in $\mathrm{CH}_{4}$ production (Shi et al., 2014). This study was congruent with conclusions reached in two recent reviews, which examined results from dairy cattle and other ruminant studies employing 16S rRNA (Tapio et al., 2017) and 'meta-omics' approaches (Wallace et al., 2017), where bacteria 
abundance produced and utilized $\mathrm{H}_{2}$ or stabilized $\mathrm{pH}$, which affected $\mathrm{CH}_{4}$ emissions and feed efficiency and archaeal activity matched substrate availability.

\subsubsection{Associating rumen community structure with methane emissions}

The combined effects of the bacterial and archaeal community structure (beta diversity) on estimated $\mathrm{CH}_{4}$ emissions were investigated by conducting PCoA on the archaeal and bacterial communities, which revealed 2-3 clusters for archaea (Fig. 4a) and two clusters for bacteria (Fig. 4b). Beta diversity is a non-parametric distance measure used in microbiology and ecology to assess the differences between environments or samples (in this case cows) as opposed to alpha diversity which takes into account the diversity within cows. Clusters of a similar nature were first reported in intestinal bacterial community types in humans (Wu et al., 2011; Arumugam et al., 2013), chimpanzees (Moeller et al., 2012), mice (Hildebrand et al., 2013) and pigs (Ramayo-Caldas et al., 2016), referred to as "enterotypes", and found associated with specific host phenotypes. This concept was extended to sheep rumen bacterial communities and referred to as "ruminotypes"(Kittelmann et al., 2014). The ruminotypes observed herein followed a continuous gradient and did not form discrete clusters, which is consistent with the latest findings in microbiome stratification (Knights et al., 2014). Importantly, we found that animal and farm factors like herd of origin, parity and lactation stage, as well as technical factors, i.e. sequencing batch, contributed to the observed variation and stratification in ruminotypes. Similar findings were reported in rumen bacterial richness at different lactation stages and over different parities (Jewell et al., 2015), suggesting later parities (higher parity cows are older) decreased bacterial richness and increased production (Lima et al., 2015). We detected a moderate heritable genetic component acting along PCo1 axis, with $\mathrm{h}^{2}$ of $20 \%$ for bacterial and $39 \%$ for archaea, when controlling for lactation stage and parity, demonstrating the first evidence of host additive genetic influence on rumen bacterial and archaeal community structure (beta diversity). All the above-mentioned factors contribute to microbiome structure and associations with host phenotypes. 
a

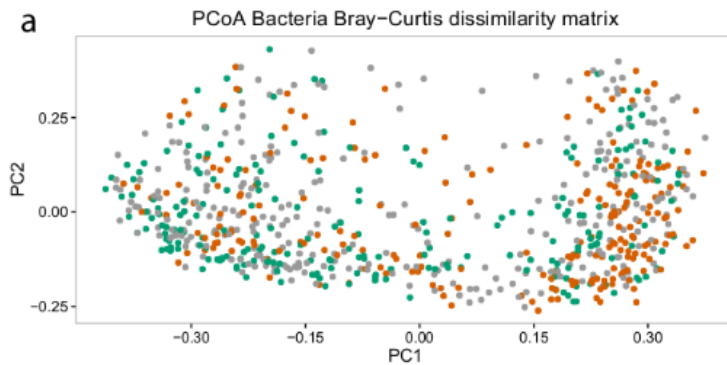

PC1 score distribution

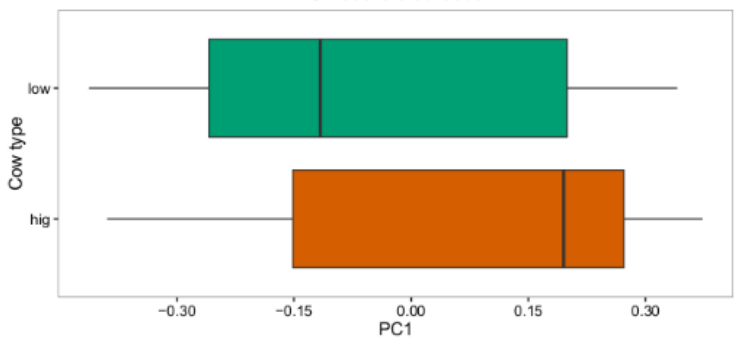

b PCoA Archaeal Bray-Curtis dissimilarity matrix

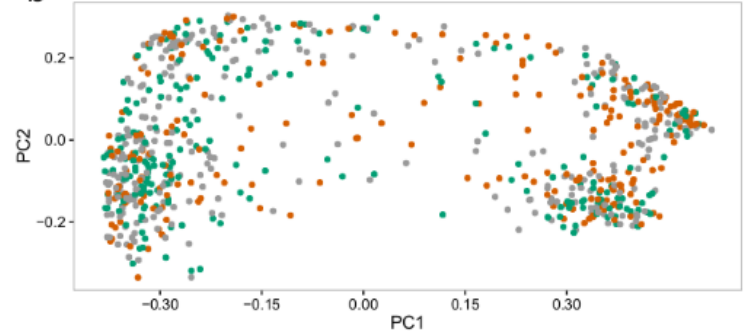

PC1 score distribution

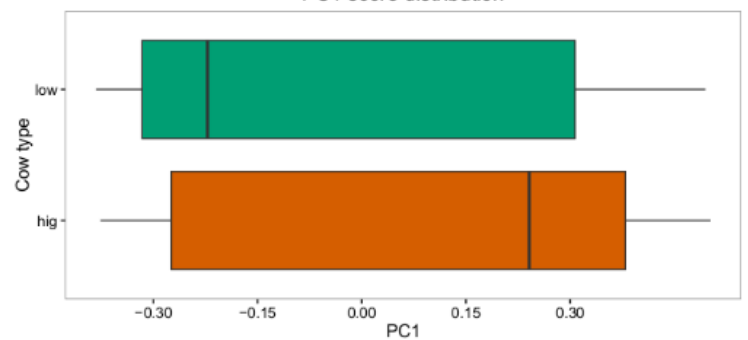

Figure 5.4 Principal coordinate analysis (PCoA) of rumen bacterial community diversity (a) and archaeal community diversity (b) based on $16 \mathrm{~S}$ rRNA amplicon sequencing contrasting 10\% highest methane emitters (orange), $10 \%$ lowest methane emitters (blue), and $80 \%$ intermediate emitters (grey). Distribution of high and low emitters along PCo1 showed significant differences $(P<0.001)$ for both figures. 
An association was detected between the highest and lowest $\mathrm{CH}_{4}$ emitters and bacterial and archaeal ruminotypes along PCo1, however, ruminotype cluster memberships were not exclusive to high and low emitters. This suggested ruminal bacterial and archaeal community structure provided a modest contribution to $\mathrm{CH}_{4}$ emission. Kittelmann et al. (2014) surveyed microbial community composition in multiple sheep cohorts with low and high $\mathrm{CH}_{4}$ yield (methane emission per kg dry matter intake, $\mathrm{CH} 4 / \mathrm{DMI})$. A ruminotype " $\mathrm{S}$ " associated with low $\mathrm{CH}_{4}$ yield and enriched with Sharpea azabuensis was reported. A follow up study in sheep also found low $\mathrm{CH}_{4}$ yielding sheep to be associated with ruminotype " $\mathrm{S}$ ", enriched with Sharpea spp. It was hypothesized a smaller rumen size and higher turnover rate promoted faster growing bacteria, such as Sharpea, which favor hetero-fermentative growth on soluble sugars, resulting in lower $\mathrm{H}_{2}$ production and subsequently decreased $\mathrm{CH}_{4}$ formation by hydrogenotrophic methanogens (Kamke et al., 2016). Smuts et al. (1995) reported passage rate (and consequently turnover rate) in sheep was heritable, indicating a possible mechanism for host genetics to influence ruminotypes. Methane emission phenotypes differed between the sheep and the present study. Kittelmann et al. (2014) assessed the amount of $\mathrm{CH}_{4}$ production per unit of DMI but not $\mathrm{CH}_{4}$ production directly. DMI measurements are not currently recorded on dairy cattle under commercial farms due to the high costs and therefore, $\mathrm{CH}_{4}$ emissions in the present study could not be corrected for feed intake. In light of the differences in phenotype definitions and similarities in ruminotypes between studies, it would be of interest in future work to obtain DMI records on cows and test if the ruminotypes observed show an increased relationship with $\mathrm{CH}_{4}$ yield. The heritability estimates for PCo1 and PCo2 indicates these measures could potentially be used as indicator traits in genetic selection should they be highly correlated to a trait of interest, however PCo1 and PCo2 (beta diversity) does not account for the total rumen microbial variation within and between individuals.

The method employed to measure $\mathrm{CH}_{4}$ production in the present study is high throughput and non-invasive, making it practically viable for measuring large numbers of animals under commercial farm conditions. However, the cost trade off of this method is that it makes use of milk yield and body weight in the estimation of $\mathrm{CH}_{4}$ production. Validation of this method with the 'gold standard method' (climate respiration chambers) has yielded highly correlated ( $r=0.8-0.89)$ and concordant (concordance correlation coefficient $=0.84$ ) results in dairy cattle (Garnsworthy et al., 2012; Negussie et al., 2016). However, the effects of body weight and milk yield on estimation of $\mathrm{CH}_{4}$ cannot be discounted and further research into the relationships between these variables and the rumen microbiome would be of value. 


\subsubsection{Quantifying variation in $\mathrm{CH}_{4}$ due to cow additive genetic effects and rumen microbiome}

In this study, we quantified the combined effects of all rumen bacterial and archaeal OTUs simultaneously on estimated host $\mathrm{CH}_{4}$ emissions using a microbial relationship matrix among cows. This is a parametric approach similar to assessing both alpha and beta diversity, as total rumen microbial variation within and between individuals is taken into account simultaneously. We expressed the combined effects as the variance ratio due to microbial composition to the total variance in estimated $\mathrm{CH}_{4}$ emissions ( $\mathrm{m}^{2}$, microbiability), an analogy to $\mathrm{h}^{2}$. Estimated $\mathrm{CH}_{4}$ emissions had $15 \% \mathrm{~m}^{2}$, indicating the combined rumen bacteria and archaea abundance of dairy cattle was associated with a considerable amount of variation in estimated $\mathrm{CH}_{4}$ emissions among animals. Ross et al. (2012) first proposed the generation of metagenomic relationship matrices in dairy cattle and reported a $\mathrm{CH}_{4}$ emission prediction accuracy of 0.47 , explaining $22 \%$ of the total variation in $\mathrm{CH}_{4}$ production (Ross et al., 2013). However, Ross et al. (2013) did not have sufficient data to estimate $h^{2}$ or microbiability $\left(\mathrm{m}^{2}\right)$ in $\mathrm{CH}_{4}$ production. A study with 207 pigs employing 16S rRNA sequencing of gut microbes, found eight of the 49 bacterial genera to be heritable and estimated $\mathrm{m}^{2}$ and $\mathrm{h}^{2}$ for feed intake $\left(\mathrm{m}^{2}=0.16, \mathrm{~h}^{2}=0.42\right)$, daily gain $\left(\mathrm{m}^{2}\right.$ $\left.=0.28, h^{2}=0.11\right)$ and feed conversion ratio $\left(\mathrm{m}^{2}=0.21, \mathrm{~h}^{2}=0.19\right)$ (Camarinha-silva et al., 2017). Only daily gain had higher $h^{2}$ compared with $\mathrm{m}^{2}$. These findings suggest agreement with holobiont theory, where variation in the genome and microbiome can cause variation in some complex traits, on which artificial, natural selection and genetic drift can act (Zilber-Rosenberg and Rosenberg, 2008; Bordenstein and Theis, 2015). However, the aforementioned study did not have adequate numbers of animals to estimate $\mathrm{m}^{2}$ and $\mathrm{h}^{2}$ simultaneously to assess the relative interactions between additive genetics and the microbiome. Thus, it was unable to assess if host additive genetics co-influences the microbiome and variation in phenotypes.

In contrast, we estimated $\mathrm{m}^{2}$ and $\mathrm{h}^{2}$ concurrently to examine the shared information between the two effects. Microbiability of estimated $\mathrm{CH}_{4}$ production decreased by two percentage points to $13 \%$ and $\mathrm{h}^{2}$ exhibited a corresponding increase from 19 to $21 \%$. This result indicated host genetic effects do interact with the microbial community composition but are not the primary mechanism for host genetic effects on estimated $\mathrm{CH}_{4}$ emissions. A possible explanation for the negligible amount of shared influence between the two relationship matrices might be the small percentage of heritable bacterial and archaeal OTUs. This implies that the rumen bacterial and archaeal communities affected estimated host $\mathrm{CH}_{4}$ emissions independently and host genetics influenced a small portion of these bacteria and 
archaea. The combined host additive genetics and rumen microbial community composition explained $\sim 34 \%$ of the total variance in estimated $\mathrm{CH}_{4}$ emissions in dairy cattle. Thus, breeding for low $\mathrm{CH}_{4}$ production can be expected to result in limited correlated genetic responses to shape the rumen microbiome and breeding can likely proceed without taking cognizance of the rumen microbiome for this trait. However, larger studies estimating genetic correlations between rumen microbiota and $\mathrm{CH}_{4}$ emissions and better functional annotation of rumen microbiota are needed to confirm this.

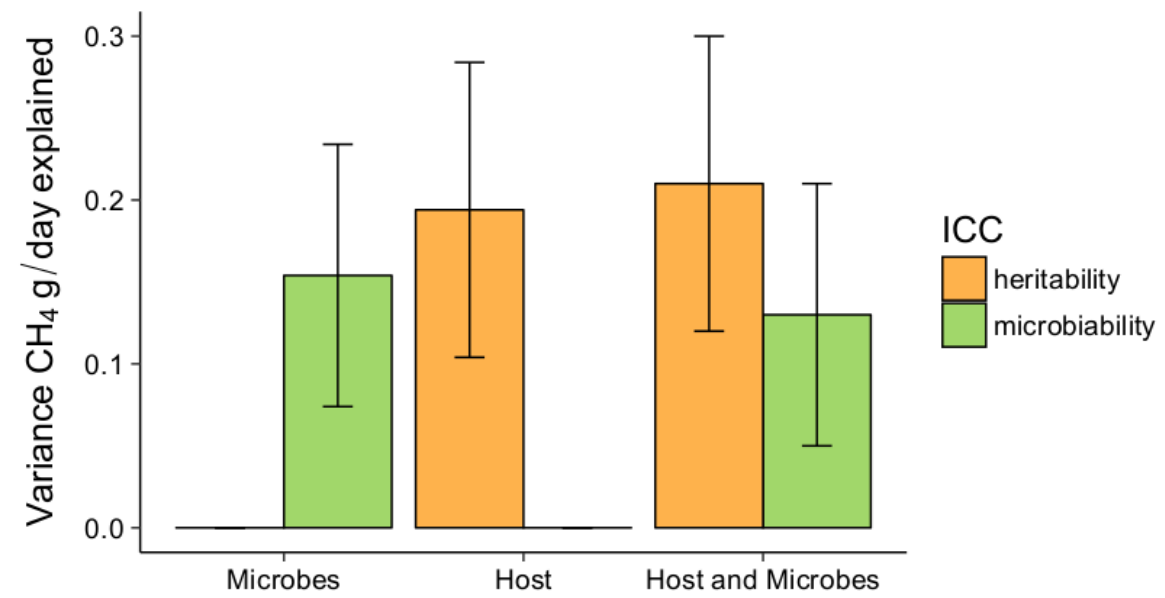

Figure 5.5. Proportion of variance in $\mathrm{CH} 4$ explained by different sources (Intra-class correlation coefficients, ICC) due to additive genetic effects (heritability) and rumen microbe content (microbiability), with respective standard errors when fit separately or jointly.

Microbiability estimates can be used as a tool for quantifying the cumulative effects of microbial abundance on phenotypes, e.g. complex diseases and quantitative traits. However, further research is required to elucidate the biological mechanisms shaping microbiability. For example, animal factors known to affect $\mathrm{CH}_{4}$ production and rumen microbial populations, such as passage rates or individual differences in feed intake might influence microbiability estimates. Human intestinal microbiome studies finds that numerous disease phenotypes are associated with microbial richness, species abundance, and microbial community structure (Le Chatelier et al., 2013; Falcony et al., 2016). Subsequent work using stool consistency and opaque markers as proxies for colonic transit time found all three metrics and disease phenotypes are partially confounded with colonic transit time (Roager et al., 
2016; Vandeputte et al., 2016). Similarly, in sheep studies, low $\mathrm{CH}_{4}$ yielding sheep are associated with lower retention time and smaller rumens (Goopy et al., 2014), relationships with specific rumen microbial clusters (Kittelmann et al., 2014) and different bacterial and archaeal species (Kamke et al., 2016). Therefore, studies are needed to determine if microbial differences among subjects associated with phenotypic differences are causative or are consequences of unknown extraneous factors. It is also necessary to clarify the mechanisms which allow rumen microbes to be passed on to successive generations, to assess the efficacy of perturbations of the rumen microbiome such as probiotics and rumen transplants aimed at desired changes to the rumen microbiome and associated changes in phenotypes (Bickhart and Weimer, 2017). Regardless of the underlying biology, quantifying the relative contribution of rumen microbes and additive genetics to complex phenotypes helps characterize whether the host genome and microbiome are acting jointly as a holobiont and highlights the merits of targeting microorganisms to achieve a specific change in a phenotype or selective breeding. Furthermore, providing additional information, such as relative abundance of rumen fungi and protozoa, or 'metaomics', including meta-transcriptomics or meta-proteomics data can be readily adopted and incorporated into this methodology, offering insights into economically important livestock and disease traits in humans.

\subsection{Conclusion}

Methane production by dairy cows is not only influenced by factors such as feed intake and composition among others, but also the cow's individual genetic composition and rumen microbial composition. Each cow's additive genetic effects influence a modest amount of variation in the abundance of a small percentage of rumen bacterial and archaeal taxa, and thereby contribute to variation in rumen microbiome composition and function. We detected associations between $\mathrm{CH}_{4}$ emissions and rumen bacteria abundance, which are known to produce methanogenesis substrates, suggesting bacteria driven $\mathrm{CH}_{4}$ production pathways. Although we detected a heritable component to ruminotypes, the association to $\mathrm{CH}_{4}$ production was weak. Concurrently, host additive genetic effects and rumen microbes contributed to inter-animal differences in $\mathrm{CH}_{4}$ production, however negligible interaction was observed between microbiability and heritability. Consequently, cow additive genetic effects on $\mathrm{CH}_{4}$ emissions were largely unmodulated by cow additive genetic effects on rumen bacteria and archaea abundance. Strategies to reduce $\mathrm{CH}_{4}$ emissions in ruminants can be optimized by a 
multifaceted approach, for instance, selective breeding to unlock host's genetic potential and strategies which may effect desired changes in the rumen microbiota like rumen transplantation, and probiotics.

\subsection{Acknowledgements}

The authors are grateful to five anonymous dairy farmers and the DCRC research herd, which contributed herd data and rumen samples to the study. Mr. Martin Bjerring kindly assisted in methane equipment installation and maintenance and Mr. John M. Obidah provided his expertise in rumen fluid sampling. The project REMRUM, project number 11-105913 under the Danish Strategic Research Council, Danish Research Council for Independent Research, Technology and Production. The first author acknowledges the Erasmus-Mundus Fellowship under the European Graduate School of Animal Breeding and Genetics.

\section{References}

Alexandratos, N., J. Bruinsma, G. Boedeker, J. Schmidhuber, S. Broca, P. Shetty, and M.G. Ottaviani. 2006. World agriculture: towards 2030/2050 Prospects for food, nutrition, agriculture and major commodity groups.

Arumugam, M., J. Raes, E. Pelletier, D. Le Paslier, J. Batto, M. Bertalan, N. Borruel, and F. Casellas. 2013. Enterotypes of the human gut microbiome. Nature 473:174-180. doi:10.1038/nature09944.Enterotypes.

Bickhart, D.M., and P.J. Weimer. 2017. Host-rumen microbe interactions may be leveraged to improve the productivity of dairy cows. J. Dairy Sci. 1-10. doi:10.3168/jds.2017-13328.

Boadi, D., C. Benchaar, J. Chiquette, and D. Massé. 2004. Mitigation strategies to reduce enteric methane emissions from dairy cows: Update review. Can. J. Anim. Sci. 84:319-335. doi:10.4141/A03-109.

Bordenstein, S.R., and K.R. Theis. 2015. Host biology in light of the microbiome: Ten principles of holobionts and hologenomes. PLOS Biol. 13:1-23. doi:10.1371/journal.pbio.1002226.

Borrel, G., N. Parisot, H.M. Harris, E. Peyretaillade, N. Gaci, W. Tottey, O. Bardot, K. Raymann, S. Gribaldo, P. Peyret, P.W. O'Toole, and J.-F. Brugère. 2014. Comparative genomics highlights the unique biology of Methanomassiliicoccales, a Thermoplasmatales-related seventh order of methanogenic archaea that encodes pyrrolysine. BMC Genomics 15:679. doi:10.1186/1471-2164-15-679.

Bray, J.R., and J.T. Curtis. 1957. An Ordination of the Upland Forest Communities of Southern Wisconsin. Ecol. Monogr. 27:325-349. doi:10.2307/1942268.

Camarinha-silva, A., M. Maushammer, R. Wellmann, M. Vital, and S. Preuss. 2017. Host genome influence on gut microbial composition and microbial 
prediction of complex traits in pigs. Genetics 206:1637-1644. doi:10.1534/genetics.117.200782/-/DC1.1.

Caporaso, J.G., J. Kuczynski, J. Stombaugh, K. Bittinger, F.D. Bushman, et al. 2010. correspondence QIIME allows analysis of high- throughput community sequencing data Intensity normalization improves color calling in SOLiD sequencing. Nat. Publ. Gr. 7:335-336. doi:10.1038/nmeth0510-335.

Caro-Quintero, A., and K.T. Konstantinidis. 2014. Inter-phylum HGT has shaped the metabolism of many mesophilic and anaerobic bacteria. ISME J. 9:958-967. doi:10.1038/ismej.2014.193.

Caro-Quintero, A., K.M. Ritalahti, K.D. Cusick, F.E. Löffler, and K.T. Konstantinidis. 2012. The chimeric genome of sphaerochaeta: Nonspiral spirochetes that break with the prevalent dogma in spirochete biology. MBio 3:1-9. doi:10.1128/mBio.00025-12.

Le Chatelier, E., T. Nielsen, J. Qin, E. Prifti, F. Hildebrand, et al. 2013. Richness of human gut microbiome correlates with metabolic markers. Nature 500:541546. doi:10.1038/nature12506.

CIGR. 2002. 4th Report of Working Group on Climatization of Animal Houses: Heat and Moisture Production at Animal and House Levels. S. Pedersen and K. Sällvik, ed. Research Centre Bygholm. DIAS, Horsens, Denmark.

Denman, S.E., G.M. Fernandez, T. Shinkai, M. Mitsumori, and C.S. McSweeney. 2015. Metagenomic analysis of the rumen microbial community following inhibition of methane formation by a halogenated methane analog. Front. Microbiol. 6:1-12. doi:10.3389/fmicb.2015.01087.

Difford, G.F., J. Lassen, and P. Løvendahl. 2016a. Interchangeability between methane measurements in dairy cows assessed by comparing precision and agreement of two non-invasive infrared methods. Comput. Electron. Agric. 124:220-226. doi:10.1016/j.compag.2016.04.010.

Difford, G.F., J. Lassen, and P. Løvendahl. 2016b. Genes and microbes, the next step in dairy cattle breeding. Page in EAAP-67th Annual Meeting.

Donoghue, K.A., T. Bird-Gardiner, P.F. Arthur, R.M. Herd, and R.F. Hegarty. 2016. Genetic and phenotypic variance and covariance components for methane emission and postweaning traits in Angus cattle. J. Anim. Sci. 94:1438-1445. doi:10.2527/jas2015-0065.

Edgar, R.C. 2013. UPARSE: highly accurate OTU sequences from microbial amplicon reads.. Nat. Methods 10:996-8. doi:10.1038/nmeth.2604.

Edgar, R.C., B.J. Haas, J.C. Clemente, C. Quince, and R. Knight. 2011. UCHIME improves sensitivity and speed of chimera detection. Bioinformatics 27:21942200. doi:10.1093/bioinformatics/btr381.

Falcony, G., M. Joossens, S. Vieira-Silva, J. Wang, Y. Darzi, et al. 2016. Populationlevel analysis of gut microbiome variation. Science (80-. ). 352:560-564. doi:10.1126/science.aad3503.

Garnsworthy, P.C., J. Craigon, J.H. Hernandez-Medrano, and N. Saunders. 2012. Onfarm methane measurements during milking correlate with total methane 
production by individual dairy cows. J. Dairy Sci. 95:3166-80. doi:10.3168/jds.2011-4605.

Geishauser, T., N. Linhart, A. Neidl, and A. Reimann. 2012. Factors associated with ruminal pH at herd level.. J. Dairy Sci. 95:4556-67. doi:10.3168/jds.20125380.

Gerber, P.., H. Steinfeld, B. Henderson, A. Mottet, C. Opio, J. Dijkman, A. Falcucci, and G. Tempio. 2013. Tackling Climate Change through Livestock - A Global Assessment of Emissions and Mitigation Opportunities.

Goodrich, J.K., E.R. Davenport, M. Beaumont, M.A. Jackson, R. Knight, C. Ober, T.D. Spector, J.T. Bell, A.G. Clark, and R.E. Ley. 2016. Genetic Determinants of the Gut Microbiome in UK Twins. Cell Host Microbe 19:731-743. doi:10.1016/j.chom.2016.04.017.

Goodrich, J.K., J.L. Waters, A.C. Poole, J.L. Sutter, O. Koren, R. Blekhman, M. Beaumont, W. Van Treuren, R. Knight, J.T. Bell, T.D. Spector, A.G. Clark, and R.E. Ley. 2014. Human genetics shape the gut microbiome. Cell 159:789-799. doi:10.1016/j.cell.2014.09.053.

Goopy, J.P., A. Donaldson, R. Hegarty, P.E. Vercoe, F. Haynes, M. Barnett, and V.H. Oddy. 2014. Low-methane yield sheep have smaller rumens and shorter rumen retention time. Br. J. Nutr. 111:578-585. doi:10.1017/S0007114513002936.

Grech-Mora, I., M.-L. Fardeau, B.K.C. Patek, B. Ollivier, A. Rimbault, G. Prensier, J.-L. Garcia, and E. Garnier-Sillam. 1996. Isolation and Characterization of Sporobacter termitidis gen. nov., sp. nov., from the Digestive Tract of the Wood-Feeding Termite Nasutitermes lujae. Int. J. Syst. Bacteriol. 46:512-518.

Henderson, C.R. 1975. Best linear unbiased estimation and prediction under a selection model published by: international biometric society stable. Biometrics 31:423-447.

Hildebrand, F., T.L.A. Nguyen, B. Brinkman, B. Yunta, Roberto Garcia Cauwe, P. Vandenabeele, A. Liston, and J. Raes. 2013. Inflammation-associated enterotypes, host genotype, cage and inter-individual effects drive gut microbiota variation in common laboratory mice. Genome Biol. 14:R4. doi:10.1186/gb-2013-14-1-r4.

Hildebrand, F., R. Tadeo, A.Y. Voigt, P. Bork, and J. Raes. 2014. LotuS: an efficient and user-friendly OTU processing pipeline. Microbiome 2:30. doi:10.1186/2049-2618-2-30.

Hill, J., C. McSweeney, A.-D.G. Wright, G. Bishop-Hurley, and K. Kalantar-zadeh. 2016. Measuring methane production from ruminants. Trends Biotechnol. 34:26-35. doi:10.1016/j.tibtech.2015.10.004.

Holmes, C.D., M.J. Prather, O.A. Søvde, and G. Myhre. 2013. Future methane, hydroxyl, and their uncertainties: Key climate and emission parameters for future predictions. Atmos. Chem. Phys. 13:285-302. doi:10.5194/acp-13-2852013.

Hristov, A.N., J. Oh, J.L. Firkins, J. Dijkstra, E. Kebreab, G. Waghorn, H.P.S. Makkar, 
A.T. Adesogan, W. Yang, C. Lee, P.J. Gerber, B. Henderson, and J.M. Tricarico. 2013. SPECIAL TOPICS-Mitigation of methane and nitrous oxide emissions from animal operations: I. A review of enteric methane mitigation options. J. Anim. Sci. 91:5045-5069. doi:10.2527/jas2013-6583.

lino, T., H. Tamaki, S. Tamazawa, Y. Ueno, M. Ohkuma, K. Suzuki, Y. Igarashi, and S. Haruta. 2013. Candidatus Methanogranum caenicola: a Novel Methanogen from the Anaerobic Digested Sludge, and Proposal of Methanomassiliicoccaceae fam. nov. and Methanomassiliicoccales ord. nov., for a Methanogenic Lineage of the Class Thermoplasmata. Microbes Environ. 28:244-250. doi:10.1264/jsme2.ME12189.

IPCC. 2014. Climate Change 2014: Synthesis Report. Contribution of Working Groups I, II and III to the Fifth Assessment Report of the Intergovernmental Panel on Climate Change.

Janssen, P.H., and M. Kirs. 2008. Structure of the archaeal community of the rumen. Appl. Environ. Microbiol. 74:3619-3625. doi:10.1128/AEM.02812-07.

Jewell, K.A., C.A. McCormick, C.L. Odt, P.J. Weimer, and G. Suen. 2015. Ruminal Bacterial Community Composition in Dairy Cows Is Dynamic over the Course of Two Lactations and Correlates with Feed Efficiency.. Appl. Environ. Microbiol. 81:4697-710. doi:10.1128/AEM.00720-15.

Johnson, D.J., L.R. Martin, and K. a Roberts. 2005. STR-typing of human DNA from human fecal matter using the QIAGEN QIAamp stool mini kit.. J. Forensic Sci. 50:802-808.

Johnson, K.A., and D.E. Johnson. 1995. Methane emissions from cattle Methane Emissions from Cattle. Anim. Sci. J. 73:2483-2492.

Kamke, J., S. Kittelmann, P. Soni, Y. Li, M. Tavendale, S. Ganesh, P.H. Janssen, W. Shi, J. Froula, E.M. Rubin, and G.T. Attwood. 2016. Rumen metagenome and metatranscriptome analyses of low methane yield sheep reveals a Sharpeaenriched microbiome characterised by lactic acid formation and utilisation. Microbiome 4:56. doi:10.1186/s40168-016-0201-2.

Kittelmann, S., C.S. Pinares-Patiño, H. Seedorf, M.R. Kirk, S. Ganesh, J.C. McEwan, and P.H. Janssen. 2014. Two different bacterial community types are linked with the low-methane emission trait in sheep. PLoS One 9:1-9. doi:10.1371/journal.pone.0103171.

Klindworth, A., E. Pruesse, T. Schweer, J. Peplies, C. Quast, M. Horn, and F.O. Glöckner. 2013. Evaluation of general 16S ribosomal RNA gene PCR primers for classical and next-generation sequencing-based diversity studies. Nucleic Acids Res. 41:1-11. doi:10.1093/nar/gks808.

Knapp, J.R., G.L. Laur, P. a Vadas, W.P. Weiss, and J.M. Tricarico. 2014. Invited review: Enteric methane in dairy cattle production: quantifying the opportunities and impact of reducing emissions.. J. Dairy Sci. 97:3231-61. doi:10.3168/jds.2013-7234.

Knights, D., T.L. Ward, C.E. McKinlay, H. Miller, A. Gonzalez, D. McDonald, and R. Knight. 2014. Rethinking "Enterotypes”. Cell Host Microbe 16:433-437. 
doi:10.1016/j.chom.2014.09.013.

Kong, Y., R. Teather, and R. Forster. 2010. Composition, spatial distribution, and diversity of the bacterial communities in the rumen of cows fed different forages. FEMS Microbiol. Ecol. 74:612-622. doi:10.1111/j.15746941.2010.00977.x.

Lassen, J., and P. Løvendahl. 2016. Heritability estimates for enteric methane emissions from Holstein cattle measured using noninvasive methods. J. Dairy Sci. 99:1959-1967. doi:10.3168/jds.2015-10012.

Lassen, J., P. Løvendahl, and J. Madsen. 2012. Accuracy of noninvasive breath methane measurements using Fourier transform infrared methods on individual cows. J. Dairy Sci. 95:890-8. doi:10.3168/jds.2011-4544.

Lassen, J., N.A. Poulsen, M.K. Larsen, and A.J. Buitenhuis. 2016. Genetic and genomic relationship between methane production measured in breath and fatty acid content in milk samples from Danish Holsteins. Anim. Prod. Sci. 56:298-303. doi:10.1071/AN15489.

Leamy, L.J., S. a Kelly, J. Nietfeldt, R.M. Legge, F. Ma, K. Hua, R. Sinha, D. a Peterson, J. Walter, A.K. Benson, and D. Pomp. 2014. Host genetics and diet, but not immunoglobulin A expression, converge to shape compositional features of the gut microbiome in an advanced intercross population of mice. Genome Biol. 15:552. doi:10.1186/s13059-014-0552-6.

Lima, F.S., G. Oikonomou, S.F. Lima, M.L.S. Bicalho, E.K. Ganda, J.C. de Oliveira Filho, G. Lorenzo, P. Trojacanec, and R.C. Bicalho. 2015. Prepartum and Postpartum Rumen Fluid Microbiomes: Characterization and Correlation with Production Traits in Dairy Cows. Appl. Environ. Microbiol. 81:1327-1337. doi:10.1128/AEM.03138-14.

Madsen, J., B.S. Bjerg, T. Hvelplund, M.R. Weisbjerg, and P. Lund. 2010a. Methane and carbon dioxide ratio in excreted air for quantification of the methane production from ruminants. Livest. Sci. 129:223-227. doi:10.1016/j.livsci.2010.01.001.

Madsen, P., J. Jensen, R. Labouriau, O.F. Christensen, and S. G. 2010b. DMU - A Package for Analyzing Multivariate Mixed Models in quantitative Genetics and Genomics. Pages 2-4 in 10th World Congress on Genetics Applied to Livestock Production.

Magoč, T., and S.L. Salzberg. 2011. FLASH: Fast length adjustment of short reads to improve genome assemblies. Bioinformatics 27:2957-2963. doi:10.1093/bioinformatics/btr507.

McAllister, T.A., and C.J. Newbold. 2008. Redirecting rumen fermentation to reduce methanogenesis. Aust. J. Exp. Agric. 48:7-13. doi:10.1071/EA07218.

Moeller, A.H., P.H. Degnan, A.E. Pusey, M.L. Wilson, B.H. Hahn, and H. Ochman. 2012. Chimpanzees and humans harbour compositionally similar gut enterotypes.. Nat. Commun. 3:1179. doi:10.1038/ncomms2159.

Moss, A.R., J.-P. Jouany, and J. Newbold. 2000. Methane production by ruminants : its contribution to global warming (Review article). Ann. Zootech. 49:231- 
253. doi:10.1051/animres:2000119.

Negussie, E., J. Lehtinen, P. Mäntysaari, A.R. Bayat, A.-E. Liinamo, E.A. Mäntysaari, and M.H. Lidauer. 2016. Non-invasive individual methane measurement in dairy cows. Animal 4:1-10. doi:10.1017/S1751731116002718.

Org, E., B.W. Parks, J.W.J. Joo, B. Emert, W. Schwartzman, E.Y. Kang, M. Mehrabian, C. Pan, R. Knight, R. Gunsalus, T.A. Drake, E. Eskin, and A.J. Lusis. 2015. Genetic and environmental control of host-gut microbiota interactions. Genome Res. 25:1558-1569. doi:10.1101/gr.194118.115.

Pedersen, S., V. Blanes-Vidal, H. Joergensen, A. Chwalibog, A. Haeussermann, M.J.W. Heetkamp, and A.J.A. Aarnink. 2008. Carbon Dioxide Production in Animal Houses: A literature review. Agric. Eng. Int. CIGR Ejournal X:1-19. doi:10.1017/CBO9781107415324.004.

Price, M.N., P.S. Dehal, and A.P. Arkin. 2010. FastTree 2 - Approximately maximumlikelihood trees for large alignments. PLoS One 5. doi:10.1371/journal.pone.0009490.

Ramayo-Caldas, Y., N. Mach, P. Lepage, F. Levenez, C. Denis, G. Lemonnier, J.-J. Leplat, Y. Billon, M. Berri, J. Doré, C. Rogel-Gaillard, and J. Estellé. 2016. Phylogenetic network analysis applied to pig gut microbiota identifies an ecosystem structure linked with growth traits. ISME J. 10:2973-2977. doi:10.1038/ismej.2016.77.

Roager, H.M., L.B.S. Hansen, M.I. Bahl, H.L. Frandsen, V. Carvalho, R.J. et al. 2016. Colonic transit time is related to bacterial metabolism and mucosal turnover in the gut. Nat. Microbiol. 1:16093. doi:10.1038/nmicrobiol.2016.93.

Roehe, R., R. Dewhurst, C.-A. Duthie, J. Rooke, N. McKain, D. Ross, J. Hyslop, A. Waterhouse, M. Watson, and J. Wallace. 2016. Bovine Host Genetic Variation Influences Rumen Microbial Methane Production with Best Selection Criterion for Low Methane Emitting and Efficiently Feed Converting Hosts based on Metagenomic Gene Abundance. PLoS Genet. 12:1-28. doi:10.1371/journal.pgen.1005846.

Ross, E.M., P.J. Moate, C.R. Bath, S.E. Davidson, T.I. Sawbridge, K.M. Guthridge, B.G. Cocks, and B.J. Hayes. 2012. High throughput whole rumen metagenome profiling using untargeted massively parallel sequencing. BMC Genet. 13:53. doi:10.1186/1471-2156-13-53.

Ross, E.M., P.J. Moate, L.C. Marett, B.G. Cocks, and B.J. Hayes. 2013. Metagenomic predictions: from microbiome to complex health and environmental phenotypes in humans and cattle.. PLoS One 8:e73056. doi:10.1371/journal.pone.0073056.

Rothschild, D., O. Weissbrod, E. Barkan, T. Korem, D. Zeevi, P.I. Costea, A. Godneva, I.N. Kalka, N. Bar, N. Zmora, M. Pevsner-Fischer, D. Israeli, N. Kosower, G. Malka, B.C. Wolf, T. Avnit-Sagi, M. Lotan-Pompan, A. Weinberger, Z. Halpern, S. Carmi, E. Elinav, and E. Segal. 2017. Environmental factors dominate over host genetics in shaping human gut microbiota composition. bioRxiv 555:150540. doi:10.1101/150540. 
Schären, M., C. Drong, K. Kiri, S. Riede, M. Gardener, U. Meyer, J. Hummel, T. Urich, G. Breves, and S. Dänicke. 2017. Differential effects of monensin and a blend of essential oils on rumen microbiota composition of transition dairy cows. J. Dairy Sci. 100:2765-2783. doi:10.3168/jds.2016-11994.

Shi, W., C.D. Moon, S.C. Leahy, D. Kang, J. Froula, S. Kittelmann, C. Fan, S. Deutsch, D. Gagic, H. Seedorf, W.J. Kelly, R. Atua, C. Sang, P. Soni, D. Li, C.S. PinaresPatiño, J.C. McEwan, P.H. Janssen, F. Chen, A. Visel, Z. Wang, G.T. Attwood, and E.M. Rubin. 2014. Methane yield phenotypes linked to differential gene expression in the sheep rumen microbiome. Genome Res. 24:1517-1525. doi:10.1101/gr.168245.113.

Sievers, F., A. Wilm, D. Dineen, T.J. Gibson, K. Karplus, W. Li, R. Lopez, H. McWilliam, M. Remmert, J. Söding, J.D. Thompson, and D.G. Higgins. 2011. Fast, scalable generation of high-quality protein multiple sequence alignments using Clustal Omega.. Mol. Syst. Biol. 7:539. doi:10.1038/msb.2011.75.

Sjaunja, L.O., L. Baevre, L. Junkkarinen, J. Pedersen, and J. Setala. 1991. A Nordic Proposal for an Energy Corrected Milk (ECM) Formula EAAP Publication 50: Performance Recording of Animals. State of the Art 1990, Centre for Agricultural Publishing and Documentation (PUDOC), Wageningen, the Netherlands.

Smuts, M., H.H. Meissner, and P.B. Cronjé. 1995. Retention time of digesta in the rumen: its repeatability and relationship with wool production of Merino rams.. J. Anim. Sci. 73:206-210.

Solden, L.M., D.W. Hoyt, W.B. Collins, J.E. Plank, R.A. Daly, E. Hildebrand, T.J. Beavers, R. Wolfe, C.D. Nicora, S.O. Purvine, M. Carstensen, M.S. Lipton, D.E. Spalinger, J.L. Firkins, B.A. Wolfe, and K.C. Wrighton. 2016. New roles in hemicellulosic sugar fermentation for the uncultivated Bacteroidetes family BS11. ISME J. 11:691-703. doi:10.1038/ismej.2016.150.

Tapio, I., T.J. Snelling, F. Strozzi, and R.J. Wallace. 2017. The ruminal microbiome associated with methane emissions from ruminant livestock. J. Anim. Sci. Biotechnol. 8:2-11. doi:10.1186/s40104-017-0141-0.

Tsilimigras, M.C.B., and A.A. Fodor. 2016. Compositional Data Analysis of the Microbiome: Fundamentals, Tools, and Challenges. Ann. Epidemiol. 26:330335. doi:10.1016/j.annepidem.2016.03.002.

Vandeputte, D., G. Falony, S. Vieira-Silva, R.Y. Tito, M. Joossens, and J. Raes. 2016. Stool consistency is strongly associated with gut microbiota richness and composition, enterotypes and bacterial growth rates.. Gut 65:57-62. doi:10.1136/gutjnl-2015-309618.

Wallace, R.J., T.J. Snelling, C.A. McCartney, I. Tapio, and F. Strozzi. 2017. Application of meta-omics techniques to understand greenhouse gas emissions originating from ruminal metabolism. Genet. Sel. Evol. 49:9. doi:10.1186/s12711-017-0285-6.

Wang, J., M. Liu, Y. Wu, L. Wang, J. Liu, L. Jiang, and Z. Yu. 2016. Medicinal herbs as 
a potential strategy to decrease methane production by rumen microbiota: a systematic evaluation with a focus on Perilla frutescens seed extract. Appl. Microbiol. Biotechnol. 100:9757-9771. doi:10.1007/s00253-016-7830-z.

Wang, Q., G.M. Garrity, J.M. Tiedje, and J.R. Cole. 2007. Naive Bayesian classifier for rapid assignment of rRNA sequences into the new bacterial taxonomy. Appl. Environ. Microbiol. 73:5261-5267. doi:10.1128/AEM.00062-07.

Ward, D. V., D. Gevers, G. Giannoukos, A.M. Earl, B.A. Meth, et al. Evaluation of 16s rDNA-based community profiling for human microbiome research. PLoS One 7. doi:10.1371/journal.pone.0039315.

Weimer, P.J., D.M. Stevenson, H.C. Mantovani, and S.L.C. Man. 2010. Host specificity of the ruminal bacterial community in the dairy cow following near-total exchange of ruminal contents.. J. Dairy Sci. 93:5902-5912. doi:10.3168/jds.2010-3500.

Wilmink, J.B.M. 1987. Adjustment of test-day milk, fat and protein yield for age, season and stage of lactation. Livest. Prod. Sci. 16:335-348. doi:10.1016/0301-6226(87)90003-0.

Wu, G.D., J. Chen, C. Hoffmann, K. Bittinger, Y. Chen, S.A. Keilbaugh, M. Bewtra, D. Knights, W.A. Walters, R. Knight, R. Sinha, E. Gilroy, K. Gupta, R. Baldassano, L. Nessel, and H. Li. 2011. Linking Long-Term Dietary Patterns with Gut Microbial Enterotypes. Science (80-. ). 334:105-109. doi:10.1126/science.1208344.

Yan, T., C.S. Mayne, F.G. Gordon, M.G. Porter, R.E. Agnew, D.C. Patterson, C.P. Ferris, and D.J. Kilpatrick. 2010. Mitigation of enteric methane emissions through improving efficiency of energy utilization and productivity in lactating dairy cows.. J. Dairy Sci. 93:2630-2638. doi:10.3168/jds.2009-2929.

Yu, J., G. Pressoir, W.H. Briggs, I. Vroh Bi, M. Yamasaki, J.F. Doebley, M.D. McMullen, B.S. Gaut, D.M. Nielsen, J.B. Holland, S. Kresovich, and E.S. Buckler. 2006. A unified mixed-model method for association mapping that accounts for multiple levels of relatedness.. Nat. Genet. 38:203-208. doi:10.1038/ng1702.

Zilber-Rosenberg, I., and E. Rosenberg. 2008. Role of microorganisms in the evolution of animals and plants: The hologenome theory of evolution. FEMS Microbiol. Rev. 32:723-735. doi:10.1111/j.1574-6976.2008.00123.x. 



\section{6}

General discussion 



\subsection{Overview}

The main research area of this $\mathrm{PhD}$ project is to investigate the genetic variation contributing to methane emission, feed efficiency and the rumen microbiome. The use of multidisciplinary approaches such as method comparison, quantitative genetics and microbiology was proposed to better understand the genetic basis of the abovementioned fields.

The following general discussion is organised into several sections. The first section is dedicated to the discussion of the primary findings of Chapter $2-3$ on the development, comparison and performance of sniffers for $\mathrm{CH}_{4}$ emission recording. The second section is dedicated to the findings of Chapter 4 , where we investigate the use of sniffers for $\mathrm{CH}_{4}$ evaluation in practice and their genetic correlations to feed efficiency. Lastly, the findings of Chapter 5 investigated genetic variation in rumen microbial abundance, and integrating this information into better understanding biology and genetic basis of $\mathrm{CH}_{4}$ production. At the end of the chapter, conclusions are drawn and some recommendations for future research are made.

\subsection{Development of non-invasive sniffer methane phenotypes}

The use of sniffers for recording breath gas concentrations and estimating $\mathrm{CH}_{4}$ production is, like other methods, under continuous development. For genetic evaluations, defining the genetic correlation between the alternative method and the gold standard is crucial to evaluating the relative merit of the alternative method. This can be seen by the breeders equation where response to selection in the gold standard $\left(R_{\mathrm{gs}}\right)$ is a function of the heritability of the alternative method $h^{2}{ }_{\mathrm{A}}$, their genetic correlation $r_{g}$ and intensity of selection (I) $\left(R_{g s}=I \cdot h_{A} \cdot r_{g}\right)$. If the genetic correlation is suitably high $\left(r_{\mathrm{g}}>0.80\right)$ (Robertson, 1959), and the alternative method is as heritable or higher, the alternative method can replace the gold standard. If the genetic correlation is moderate $r_{\mathrm{g}}>|0.3|$, it may still be useful as an indicator trait. However, measurements using both methods on $10^{3}-10^{4}$ related individuals are needed to estimate a genetic correlation with meaningful standard errors (Visscher, 1998). Even larger numbers are required if measurements are made on different animals or animals at different points in time, or environments (Bijma and Bastiaansen, 2014). The high cost, limited throughput and time or invasiveness of the gold standard drives the need for alternative methods. Other ways of assessing the merit of an alternative method are therefore needed prior to the investment in recording thousands of animals usually required for estimating genetic correlations. 


\section{Text Box 1. Accuracy and precision of phenotypes and random solutions}

The statistical terms accuracy and precision are not synonymous at the phenotypic level (measurement) and genetic level (random solutions), see Barnhart et al, (2007a) for a discussion of definitions on agreement with continuous measurements. Phenotypic accuracy is a measure of 'systematic error' (also commonly called mean or intercept bias) and is the fixed difference between what is measured by a method and the known or 'true value'. The gold standard method is taken to be the method, which measures the 'true value' with the least systematic error, and by definition is the most accurate method. Precision is a measure of the 'random error' and is the closeness of multiple measurements taken using the same method on a subject under the conditions the 'true value' has not changed or the change in 'true values' is accounted for statistically or by careful design. The phenotypic variance of measurements can then be decomposed into the between-subject variation $\left(\sigma^{2}\right.$ ) (the variation between 'true values' in a population) and the within-subject variation $\left(\sigma^{2}\right.$ ) (the random error or residual variation around 'true values'). An alternative method can therefore be more precise than the gold standard method if the residual error of the alternative method is smaller than that of the gold standard. Precision cannot be determined in the absence of repeated measures per subject. The repeatability $(t)$ of a method under the conditions of assessing precision described above, is a metric for comparing precision between methods. Defined as the ratio of between-subject variation to the total subject variation $\left(t=\sigma^{2}{ }_{b} /\left(\sigma^{2}{ }_{b}+\sigma^{2}{ }^{2}\right)\right.$. The accuracy of random solutions such as estimated 'true values' from repeated measures per subject or estimated breeding values from records on relatives is the correlation between the true random solutions and estimated random solution from a linear mixed model. This definition is somewhat confusingly similar to precision of phenotypes as is seen by the equation for random solution accuracy $r_{a y}=\sigma_{b}^{2} / V\left(\sigma_{b}(t+(1-t) / n) \cdot \sigma_{y}^{2}\right)$ see Mrode, R., 2003 for proofs and extension to estimated breeding values. From this equation, it can be seen that the accuracy of random solutions are directly proportional to the repeatability or phenotypic precision and increases as the number of records per individual $(n)$ increases. 
Instrument or method comparison and validation studies, which identify and quantify phenotypic sources of (dis)agreement such as accuracy, precision and correlation (Barnhart et al., 2007a) are a viable first step. Knowledge of sources of (dis)agreement is indispensable as it facilitates further corrective steps, continued development of the method and informs the scope of the usage prior to investment in recording thousands of animals.

Precision can only be assessed if repeated measures are made per individual, which allows for partitioning of variance into between- and within-subject variance (precision). This facilitates the estimation of individual level correlations using between-subject (co)variances. Importantly, the repeatability serves as the upper threshold for heritability estimates and individual level correlations between methods serve as proxies for genetic correlations (Wolak et al., 2012; Dingemanse and Dochtermann, 2013).

The accuracy of a method refers to measurements being close to the 'true value' of interest, a prerequisite of which is the gold standard, which is assumed to record the 'true value' (Hartnack, 2014). In the case of $\mathrm{CH}_{4}$ emission, this is indirect calorimetry in RC. In the general introduction, we challenge the recording of the 'true value' of $\mathrm{CH}_{4}$ emissions from dairy cattle, as it changes within day and from day to day. Furthermore, the RC often compare poorly within and between research facilities (Gardiner et al., 2015) and animal behaviour changes due to confinement within $\mathrm{RC}$ can change the true value of $\mathrm{CH}_{4}$ emission due to changes in feed intake and may not necessarily be representative of the true value of $\mathrm{CH}_{4}$ emission under grazing conditions (Pinares-Patiño et al., 2013). Regardless of the shortcomings of the RC method, assessment of method accuracy cannot be conducted without defining a gold standard. Precision is the variability between repeated measures on the same subject, thus, it is a measure of the random error (precision) of a method (ISO, 1994). Repeatability is the ratio of between subject variance to the total variance and used as a metric for precision but also the correlation between repeated measures of the same method. To this end, the repeatability of a method can be informative because if a method is not repeatable, it will not agree with another method (Hanneman, 2008). 


\section{Text Box 2. Correlations at phenotypic, individual and genetic levels}

Pearson's product moment correlation is a popular method for assessing the linear association between two measurements. This metric assumes independence of error between measurements. In the case of single measurements per subject with two methods the phenotypic correlation is the ratio of covariance the product of standard deviations of each method $\left(r_{p}\right.$ $=\sigma_{p 1, p 2}^{2} /\left(\sigma_{p 1} \cdot \sigma_{p 2}\right)$. However, if multiple measurements are taken per subject, as is the case when assessing precision, then the random errors on each subject are likely not independent. In this case, partitioning the variation into between- $\left(\sigma_{b}^{2}\right)$ and within-subject variation $\left(\sigma^{2}\right)$ can account for nonindependence. To this end, the individual level correlations is more appropriate, as this estimates the correlation between estimated random subject solutions for each method $R_{1}=\sigma^{2}{ }_{b 1, b 2} /\left(\sigma_{b 1} \cdot \sigma_{b 2}\right)$. In the case that one or both methods are measured with imprecision $(t<1)$ and the random errors are not correlated between methods, then $r_{p}$ in the presence of repeated measures is biased downwards and a bias predictor of the correlation between 'true values'. In the case of genetic correlations, the genetic relationships between individuals also affects the independence of measures. For repeated measures, the between-subject variation is further partitioned into additive genetic variation $\left(\sigma^{2}{ }_{a}\right)$ and permanent environmental variation $\left(\sigma^{2}\right.$ pe which includes non-additive genetics, maternal, common environmental and learned effects etc. If the permanent environmental variation is the same sign as the genetic variation (not always the case), then the individual level correlation is a better predictor of the genetic correlations than phenotypic correlations.

A prerequisite of method agreement is a positive linear association between measurements from each method. The most common metric for assessing linear associations is correlation, or Pearson's product-moment correlation. However, a high correlation $(r=1)$ does not ensure perfect agreement as it fails to take into account differences in accuracy $\left(\mu_{1} \neq \mu_{2}\right)$ or precision $\left(\sigma^{2}{ }_{\mathrm{e} 1} \neq \sigma_{\mathrm{e} 2}^{2}\right)$ (Altman and Bland, 1983). Conversely, measurements of two methods can have the same means (accuracy $\left.\mu_{1}=\mu_{2}\right)$ and the same magnitude precision $\left(\sigma^{2}{ }_{e 1}=\sigma_{e 2}^{2}\right)$ but have no linear association $(r=0)$, thus high accuracy and precision is meaningless. Furthermore, accuracy, precision and correlation are interrelated facets of agreement. For instance, as imprecision increases, the statistical power to detect significant differences in accuracy decreases. Moreover, the correlation between 
two variables is biased downwards in the presence of repeated measurements when one or both methods is measured with error (i.e. $\mathrm{t}<1$ ) (Spearman, 1904; Adolph and Hardin, 2007). The implications are that method comparison studies must use repeated measures per subject per method to estimate precision, but must also account for the attenuating effects of random error on the phenotypic correlation by estimating the individual level correlations. This is readily done in bivariate linear mixed effect models, commonly known in genetics as bivariate repeatability animal models (Hamlett et al., 2004; Roy, 2009; Downs and Dochtermann, 2014).

\section{Text Box 3. Assessing agreement with CCC and CIA}

Agreement between measurements from two methods requires that all three facets of (dis)agreement: accuracy, precision and correlation are assessed. Failing to assess all three facets can lead to miss-leading conclusions. Scaled agreement indices such as the concordance correlation coefficient (CCC) and the coefficient of Individual agreement (CIA) summarise all three facets into a single value ranging from $0-1$, where 0 indicates no agreement and 1 indicates full agreement (Barnhart et al., 2007b). The CCC for repeated measures is:

$$
C C C=\left(2 \cdot \sigma_{b 1} \cdot \sigma_{b 2} \cdot r_{1}\right) /\left(2 \sigma_{b 1} \cdot \sigma_{b 2}+\left(\mu_{1}-\mu_{2}\right)^{2}+\left(\sigma_{b 1}-\sigma_{b 2}\right)^{2}+\sigma_{e 1}^{2}+\sigma_{e 2}^{2}\right)
$$

The CIA can only be estimated for repeated measures as:

$$
\mathrm{CIA}=\left(2 \cdot \sigma^{2}{ }_{\mathrm{e} 1} \cdot \sigma_{\mathrm{e} 2}^{2}\right) /\left(2\left(1-r_{1}\right) \sigma_{\mathrm{b} 1} \cdot \sigma_{\mathrm{b} 2}+\left(\mu_{1}-\mu_{2}\right)^{2}+\left(\sigma_{\mathrm{b} 1}-\sigma_{\mathrm{b} 2}\right)^{2}+\sigma_{\mathrm{e} 1}^{2}+\sigma_{\mathrm{e} 2}^{2}\right)
$$

In general for both $\mathrm{CCC}$ and $\mathrm{CIA}$, as the individual level correlations increase and difference in means $\left(\mu_{1}-\mu_{2}\right)$ (accuracy), differences in the between subject variation $\left(\sigma_{b 1}-\sigma_{b 2}\right)$ decrease, the resulting agreement increases. However, for the CCC as the between subject variation increases so too does the CCC. As the between subject variation in population specific, comparing methods on a heterogeneous population may inflate the CCC between methods. Conversely, for the $\mathrm{CIA}$, if one or both of the methods has higher imprecision (i.e. within-subject variation increases $\sigma^{2}{ }_{\mathrm{e} 1}+\sigma_{\mathrm{e} 2}^{2}$ ), the $\mathrm{CIA}$ maybe inflated. The two metrics are therefore complementary in assessing method agreement. Using the threshold of bioequivalence from the Food and Drug Administration, the threshold for good agreement with $\mathrm{CIA}>0.455$ and $\mathrm{CIA}>$ 0.80 for excellent agreement (Barnhart et al .,2007b). McBride, G.B. (2005) suggested a threshold of CCC $<0.90$ as poor, $0.95<$ CCC $<0.99$ as substantial and CCC $>0.99$ as almost perfect. 
A prerequisite of genetic and many other studies is the individual identification of cows for linking phenotypic information to familial relationship information (Falconer and Mackay, 1996). To this end, it is useful to know the sensitivity, or the true positive identification rate (where the cow is measured by sniffers and identified) and specificity, or the true negative identification rate (where the cow is not being measured and not identified). In Chapter 2, we developed and validated a time alignment algorithm and detected a systematic time series difference of 1 hour and 1 minute and a constant drift of two seconds per day between the digital clocks time stamping the gas recording and the AMS visitation. The 1 hour systematic time difference was due to inconsistent application of daylight saving time, which would result in a specificity of $50 \%$ and sensitivity of $50 \%$ over a 1 year period. After the application of the time alignment algorithm, both metrics where restored to $100 \%$ during the recording period. To the best of our knowledge, this potentially large source of error has not been reported elsewhere in $\mathrm{CH}_{4}$ recording or the integration of time series in other automated recording devices including AMS, feed bins and activity recording devices. Sensitivity and specificity assessments are needed before method comparisons can proceed because inaccurate subject identification will result in poor comparisons, regardless of the methods compared.

\subsubsection{Predicting $\mathrm{CH}_{4}$ production from sniffers with the $\mathrm{CO}_{2}$ ratio method}

In Chapter 3, we compare $\mathrm{CH}_{4}$ emissions using sniffers with subsequent measurements in RC for 10 Danish Holstein and 10 Danish Jersey cows, with the express purpose of assessing individual level correlations. Although time elapsed between the two methods, as well as a change in diet (underlying biology of the 'true values' will have changed), we can still compare the accuracy of the two methods, recognising the limitations of our study will cause an underestimation of agreement.

The $\mathrm{CH}_{4}$ production estimated from sniffers using the $\mathrm{CO}_{2}$ ratio method differed significantly $(P<0.05)$ by an overestimation of $9.9 \%$ corresponding to $52 \mathrm{~L}$ $\mathrm{CH}_{4}$ /day. Negussie et al. (2016) compared 21 Nordic red cows in the RC, with estimated $\mathrm{CH}_{4}$ production, using a sniffer installed in a concentrate feeder and predicted $\mathrm{CO}_{2}$ tracer gas from estimated metabolisable energy intake and found a non-significant $6 \%$ under prediction of $36.4 \mathrm{~L} /$ day. In the case of the comparison in Chapter 3, we cannot determine the cause of inaccuracy due to the confounding effects of diet and time but together with the results of Negussie et al. (2016), we can infer that sniffer methods using the $\mathrm{CO}_{2}$ ratio method are less accurate $(6-10 \%)$ or potentially as accurate as the RC. 
Comparing sub-components of the sniffer $\mathrm{CO}_{2}$ ratio method for accuracy, the predicted $\mathrm{CO}_{2}$ tracer gas in Chapter 3 is $3.5 \%$ higher than recorded $\mathrm{CO}_{2}$ production in the $\mathrm{RC}$ and not significantly different $(P>0.05)$. In a study evaluating the accuracy of the predicted $\mathrm{CH}_{4}$ production using $\mathrm{CO}_{2}$ tracer gas against measured $\mathrm{CH}_{4}$ production in the RC, Hellwing et al. (2013) found a significant systematic difference in accuracy of $16.6 \%$ or 96 L/day under prediction in 157 records on lactating Danish Holstein cows in 8 experiments covering 30 experimental diets. Similarly, a study comparing predicted $\mathrm{CH}_{4}$ production from predicted $\mathrm{CO}_{2}$ tracer gas and recorded $\mathrm{CO}_{2}$ tracer gas in the $\mathrm{RC}$, a non-significant under prediction of $3.9 \%$ or $5.8 \mathrm{~L} /$ day was observed in Dexter Heifers (Haque et al., 2017). From the findings of these studies, it appears that the prediction of $\mathrm{CO}_{2}$ tracer gas contributes a negligible amount of deviations from accuracy across a range of breeds and diets. Differences due to the predicted $\mathrm{CO}_{2}$ tracer gas were systematic and can be corrected for by the addition of a constant correction factor or through statistical modelling. However, prediction equations based on the relationship between $\mathrm{CO}_{2}$ production and other phenotypes, such as milk production, can change over generations due to genetic selection and thus requires periodic re-evaluation. Furthermore, the prediction equations for $\mathrm{CO}_{2}$ production, described in Madsen et al. (2010), do not take into account mobilization of body reserves and thus remain a potential source of bias, particularly in early lactation.

The recorded ratio of $\mathrm{CH}_{4}$ to $\mathrm{CO}_{2}$ in the AMS was however, $12 \%$ under that of the recorded ratio in the $\mathrm{RC}(P>0.01)$ (Chapter 3$)$. In a comparison study using the GF system with or without active airflow (similar to sniffers), Huhtanen et al. (2015) found that the recorded ratio of $\mathrm{CH}_{4}: \mathrm{CO}_{2}$ production (mass flux measure) inconsistently differed from that of the ratio of $\mathrm{CH}_{4}: \mathrm{CO}_{2}$ concentration (concentration measure 'sniffer'). In the first experiment, a standard GF concentrate feeder system was used and the ratio of $\mathrm{CH}_{4}: \mathrm{CO}_{2}$ concentration under-recorded significantly as compared to the ratio of $\mathrm{CH}_{4}: \mathrm{CO}_{2}$ production $(P<0.001)$ by $1.3 \%$ in Nordic red cattle (Huhtanen et al., 2015). However, in the second experiment, the GF system was retrofitted to AMS and significantly over-recorded as compared to the ratio of $\mathrm{CH}_{4}: \mathrm{CO}_{2}$ production $(\mathrm{P}<0.001)$ by $7.8 \%$ in Holstein Friesian cows (Huhtanen et al., 2015). Unfortunately, it is not possible to quantify from these studies whether one or both gases is contributing to the inaccuracy. From these studies, it is clear that deviations in the accuracy of the $\mathrm{CH}_{4}: \mathrm{CO}_{2}$ ratio will have consequences for the accuracy of predicted $\mathrm{CH}_{4}$ production. Further work is required to ascertain the direct causes of inaccuracy due to partial confounders such as breed, installation device, sensor and diet. Particularly if the deviation in the $\mathrm{CH}_{4}: \mathrm{CO}_{2}$ is due to inaccuracy of the sensor for $\mathrm{CH}_{4}, \mathrm{CO}_{2}$ or both. This point is illustrated by the 
findings in Chapter 2, where significant differences between $\mathrm{CH}_{4}$ and $\mathrm{CO}_{2}$ concentrations were detected using two different sniffer sensors in the same AMS feed bin.

As is reported in Chapter 3, the repeatability of average weekly predicted $\mathrm{CH}_{4}$ production ( $\mathrm{t}=0.58 \pm 0.11$ ) is not significantly different to subsequent average daily $\mathrm{CH}_{4}$ production in the $\mathrm{RC}(\mathrm{t}=0.61 \pm 0.12$ ). However, it is important to note that the time window is larger for the predicted $\mathrm{CH}_{4}$ production as compared to the $\mathrm{RC}$, which is shown in Chapter 2, to reducing residual error and thus increasing repeatability. The implications of this finding are that, in order to achieve adequate precision using sniffers, a longer recording period is required.

The correlation between predicted $\mathrm{CH}_{4}$ production and recorded $\mathrm{CH}_{4}$ production in Chapter 3 yielded individual level correlations of $0.77 \pm 0.18$ and similar ranking. In the comparisons of Negussie et al., (2016), a phenotypic correlation of 0.80 was back calculated from the CCC estimated between the two methods. In the correlation between sniffer using the eructation peak method and $\mathrm{RC}, \mathrm{CH}_{4}$ production was 0.89 (Garnsworthy et al., 2012). Although, deviating from unity, these correlations are substantial when placed in context of other methods of recording $\mathrm{CH}_{4}$ production. For instance, an individual level correlation of 0.81 between $\mathrm{CH}_{4}$ production from SF6 and RC in beef heifers (McGinn et al., 2006), and a phenotypic correlation of 0.83 in Holstein x Norwegian red (Muñoz et al., 2012). Comparisons from the GF compared to RC have yielded phenotypic correlations of $0.6-0.24$ in dairy cattle (Garnett, 2012; Hammond et al., 2015), but considerably higher in shorthorn cattle (0.85) (Velazco et al., 2015). Phenotypic correlations between $\mathrm{SF}_{6}$ and $\mathrm{GF}$ have been reported in the range of $0.4-0.77$ in dairy cattle (Hammond et al., 2015; Hristov et al., 2016). These results place the correlation between the sniffer method using $\mathrm{CO}_{2}$ ratio and $\mathrm{RC}$ well within the range of more accepted methods.

Assessing the agreement through calculating the CCC and the $\mathrm{CIA}$, scales the correlation between the methods based on the deviations from accuracy and precision. Both metrics have inherent shortcomings, which can be overcome by reporting both simultaneously, something which is rarely done in literature. The CCC is population specific and thus influenced by population heterogeneity, which can result in inflation when a highly heterogeneous population is measured with both methods (Barnhart et al., 2007b). The CIA is less influenced by population heterogeneity, but evaluates agreement relative to imprecision, thus a method with a low repeatability can have an inflated CIA (Barnhart et al., 2007b; Haber et al., 2010). From the comparison in Chapter 3 we find a $(C C C=0.56)$ and $(C I A=0.11)$, which indicates some agreement between methods, but the sniffer method using 
$\mathrm{CO}_{2}$ tracer gas is not equivalent to the RC. However, it is important to note that the time elapsed between measurements and the change in diets in the results from Chapter 3 will bias these metrics downwards. In the study of Negussie et al. (2017), the concordance between methods was $C C C=0.65-0.93$, but in the absence of repeated measures from the $\mathrm{RC}$ it was not possible to calculate the $\mathrm{CIA}$. Studies comparing $\mathrm{SF}_{6}$ and $\mathrm{RC}$ found the CCC ranging from 0.10 (Garnett, 2012) to 0.68 (Muñoz et al., 2012) in dairy cattle and CCC $=0.79$ in beef heifers (McGinn et al., 2006), GF and RC CCC $=0.10$ and the GF and $S_{6}$ CCC $=0.60$ (Hammond et al., 2015). None of the studies reported on precision, within-cow coefficient of variation or repeatability and, thus, it was not possible to calculate the CIA to determine if high CCC values are due to population heterogeneity or true method agreement. What is clear from these findings is that there is some agreement between different methods but none of the methods agree sufficiently well with the RC at the phenotype level to be deemed equivalent. It is also clear that the sniffer method performs comparably, and in some cases, better than the $\mathrm{SF}_{6}$ and GF methods reported. The implications of this are that if the intended purpose of the methods are to quantify individual cow $\mathrm{CH}_{4}$ production for comparing for instance two feed additive or for taxing farmers, then none of the alternative methods agree suitably well at the phenotype level to replace the RC (see Text Box 3).

If the intended purpose of a method is genetic evaluations, then the genetic correlation between methods is the most informative for assessing how best to incorporate an alternative method into a selection index. However, individual level correlations, when methods are imprecise (i.e. $t<0.80$ ), or single measure phenotypic correlations, when precision is high (i.e. $t>0.80$ ), from carefully controlled method comparison studies are good indicators of the sign and magnitude of genetic correlations (see Text Box 2), but at a fraction of the cost. This point is illustrated in sheep where portable accumulation chambers (PAC) are a short-term total emission flux method alternative to RC. In earlier studies, Goopy et al. (2011) compared the two methods in 39 sheep, by measuring for 22 hours in the $\mathrm{RC}$ and then measuring 1 and 2 hours immediately after, in the PAC. The phenotypic correlation between methods was reported as 0.67 (from supplementary material on 13 sheep we find CCC $=0.32$ ). In a subsequent genetic study on 3601 lambs with 4733 records in PAC and 8655 in RC, Jonker et al., (2018) found a genetic correlation of $0.67 \pm 0.11$ for $\mathrm{CH}_{4}$ production between methods. In this case, the method comparison on 39 sheep and the genetic evaluation on 3601 sheep both show that PAC is not equivalent to the RC, but is a highly correlated but separate trait. Importantly, Jonker et al. (2018) did not report individual level correlations, but they did report phenotypic correlations in the presence of repeated measurements, 
which were substantially lower $r p=0.27 \pm 0.02$ and a biased predictor of the genetic correlation due to attenuating effects of permanent environments and residual error. To this end, the individual level correlations found in Chapter $3(0.77 \pm 0.11)$ are very promising as proxies for genetic correlations between sniffers with the $\mathrm{CO}_{2}$ ratio methods and RC.

\subsubsection{Using $\mathrm{CH}_{4}$ breath concentrations directly}

The use of predicted $\mathrm{CO}_{2}$ tracer gas poses some challenges for practical implementation in genetic evaluations, as predicted $\mathrm{CH}_{4}$ production is a linear combination of ECM and BW, both of which are heritable traits and genetically correlated to $\mathrm{CH}_{4}$ production (Lassen and Løvendahl, 2016). Moreover, ECM is heavily under selection. For this reason, the direct measurement of $\mathrm{CH}_{4}$ concentration is attractive as a potential indicator trait. Garnsworthy et al. (2012) proposed the use of $\mathrm{CH}_{4}$ concentration from sniffers installed in the AMS with a gas recovery correction factor to approximate $\mathrm{CH}_{4}$ production and found this to be highly correlated (0.89) with $\mathrm{CH}_{4}$ production in $\mathrm{RC}$ for 12 Holstein Friesians. Methane breath concentration is a separate but likely correlated phenotype to $\mathrm{CH}_{4}$ production in the RC and, thus, evaluating agreement outside of individual level or genetic correlations is of limited use.

As the RC records the concentration of gases, it is possible to install alternative methods within the $\mathrm{RC}$ and make method comparisons for discerning sources of error. However, the RC are under very stable and high rates of airflow, if the airflow rate is constant and recovery rates are 1 , the correlation between background corrected $\mathrm{CH}_{4}$ concentration in the $\mathrm{RC}$ and $\mathrm{CH}_{4}$ production from the $\mathrm{RC}$ will be 1 . This means that comparing $\mathrm{CH}_{4}$ concentration from alternative methods installed within the $\mathrm{RC}$ are, in effect, sensor comparisons and will not reflect the realized correlations between $\mathrm{CH}_{4}$ breath concentration under variable conditions on farm and $\mathrm{CH}_{4}$ production in the $\mathrm{RC}$. However, these comparisons do give an impression of the effects of variable head movement on the sniffer methods under controlled atmospheric conditions.

As an unpublished sub-experiment of Chapter 3, we installed the sniffer instrument directly into the feed bin of the RC for 19 days, culminating in 2-3 measuring days on 5 Holstein and 4 Jersey cows. The objective of this comparison was to assess the performance of the $\mathrm{CH}_{4}$ and $\mathrm{CO}_{2}$ sensor under the carefully controlled conditions of the RC. Data was analysed using the models in Chapters 2-

3 , the results of which are presented in table 6.1 below: 
Table 6.1 Sources of (dis)agreement ${ }^{1}$ between sniffer sensors and $\mathrm{RC}$ sensors for daily $\mathrm{CH}_{4}$ and $\mathrm{CO}_{2}$ concentrations

\begin{tabular}{|c|c|c|c|c|c|c|c|c|}
\hline Measure $^{2}$ & Mean (SE) & CV\% & $\sigma_{B}^{2}$ & $\sigma_{\mathrm{w}}^{2}$ & Rep & $r_{p}$ & CCC & $\mathrm{ClA}$ \\
\hline $\mathrm{CH} 4$ sniffer & $220^{a}(17.4)$ & 1.7 & $2,014^{a}$ & $202^{\mathrm{a}}$ & $0.90^{\mathrm{a}}$ & & & \\
\hline $\mathrm{CH} 4 \mathrm{RC}$ & $214^{\mathrm{a}}(12.9)$ & 1.6 & $1,408^{b}$ & $183^{a}$ & $0.87^{a}$ & 0.95 & 0.93 & 0.52 \\
\hline CO2 sniffer & $2733^{a}(195)$ & 22.6 & $310,579^{a}$ & $69,408^{a}$ & $0.82^{a}$ & & & \\
\hline $\mathrm{CO} 2 \mathrm{RC}$ & $2562^{\mathrm{a}}(118)$ & 14.1 & $120,927^{b}$ & $10,135^{b}$ & $0.92^{b}$ & 0.8 & 0.66 & 0.56 \\
\hline
\end{tabular}

${ }^{1}$ Sources of (dis)agreement: $\mathrm{CV} \%=$ coefficient of variation $\%, \sigma_{\mathrm{W}}{ }^{2}=$ Inter-cow variance, $\sigma_{\mathrm{B}}{ }^{2}=$ Intra-cow variance i.e. precision, $\operatorname{Rep}=$ repeatability indicates the ratio of inter cow variation to total variation, not to be confused with repeatability coefficient used in agreement studies, $r p=$ Pearson's correlations coefficient, CCC = Lin's concordance correlation coefficient, $\mathrm{CIA}=$ Coefficient of individual agreement. ${ }^{2}$ Gas concentrations in ppm. Superscripts denoted significant differences between methods. 
From this sensor comparison, we find high agreement for both $\mathrm{CH}_{4}$ and $\mathrm{CO}_{2}$ sensors and no detectable difference in accuracy for both gases and precision for $\mathrm{CH}_{4}$. However, the $\mathrm{CO}_{2}$ sensor from the sniffer was significantly less precise than the $\mathrm{CO}_{2}$ sensor from the RC. This validation study gives a high level of confidence in the performance of the sniffer sensors under stable and controlled conditions. Based on the high phenotypic correlations, $\mathrm{CCC}$ and $\mathrm{ClA}_{\mathrm{A}} \mathrm{CH}_{4}(\mathrm{rp}=0.95, \mathrm{CCC}=0.93$ and $\mathrm{CIA}$ $=0.52$ ), and that the correlation between $\mathrm{CH}_{4}$ concentration and $\mathrm{CH}_{4}$ production in the $R C$ is $\sim 1$, one might incorrectly conclude that sniffer breath concentrations are the same trait as mass flux. Interestingly, for both sensor comparisons, the sniffer gave significantly higher between-animal variations, indicating differential animal to sensor interaction. The RC sensor samples from the inflowing and outflowing air and does not interact with the cow, but the sniffer was installed inside the feed bin of the RC. The larger between-animal variation between the two sensor sets could be due to variation in the distance from the cow head to the sniffer sensor sampling point or the exhalation and eructation rate between cows. Due to the constant airflow rates within the $\mathrm{RC}$, it is unlikely due to variable air velocity.

The effects of cow head movement, variable proximity to the sensor sample inlet and dilution due to exhalation rate and air velocity have been assessed under controlled and barn conditions in two studies using dummy cows, the results of which are summarised in Table 6.2 below (Huhtanen et al., 2015; Wu et al., 2018). Huhtanen et al., (2015) released a known amount of $\mathrm{CO}_{2}$ with an exhalation rate controlled using a foot pump and recorded the response using the GF as a flux or sniffer (GF study). Wu et al. (2018) used the artificial reference cow (ARC), a cylinder and piston system which controls exhalation rate, temperature and a mass flow controller for releasing known amounts of $\mathrm{CH}_{4}$ at differing levels (Wu et al., 2015) and recorded the response using a sniffer (Gasmet as used in Chapter 2) (ARC study). Both studies found that under controlled conditions, without variable air movement, cow head movement and exhalation rate, the captured fraction of gas (CFG) (relative difference in accuracy) was $100 \%$ (no difference in accuracy) and the CV less than that of RC $12 \%$ (an indicator of precision). However, when the distance from sensor sampling inlet to exhalation point was increased to $30 \mathrm{~cm}$, the CFG decreased to $78 \%$ and $62 \%$ and the CV increased to $29.8 \%$ and $8.8 \%$ in the GF and ARC study, respectively. In general, from Table 6.2, it can be seen that air velocity in the feed bin increased from 0.09 to $0.24 \mathrm{~m} / \mathrm{s}$ which further decreased the CFG from 26 to 35 and increased the CV from 17.1 to $26.9 \%$, respectively. Cow head movement had limited effects on CFG (102-109\%) but increased the CV (10.4 - $20 \%)$. Increasing exhalation rate systematically decreased CFG but had limited effects on CV. 
Table 6.2: Effects of variable muzzle position, head movement, exhalation rate and air velocity on the captured fraction of gas (CFG) and coefficient of variation (CV) in GF study Huhtanen et al. 2015 and ARC study Wu et al. 2018.

\begin{tabular}{|c|c|c|c|c|c|c|c|c|c|}
\hline $\begin{array}{l}\text { Muzzle } \\
\text { position }(\mathrm{cm})\end{array}$ & $\begin{array}{l}\text { Tidal } \\
\text { Volume (L) }\end{array}$ & $\begin{array}{l}\text { Breath } \\
\text { (Breath/min) }\end{array}$ & $\begin{array}{l}\text { Head } \\
\text { movement }\end{array}$ & $\begin{array}{l}\text { Sampling } \\
\text { (L/min) }\end{array}$ & $\begin{array}{l}\text { Exhalation } \\
(\mathrm{L} / \mathrm{min})\end{array}$ & $\begin{array}{l}\text { Air velocity } \\
(\mathrm{m} / \mathrm{s})\end{array}$ & $\begin{array}{l}\text { CFG } \\
(\%)\end{array}$ & $\begin{array}{l}\text { CV } \\
(\%)\end{array}$ & Study \\
\hline 0 & 3.5 & 30 & static & 1 & 111 & 0 & 100 & 9.8 & GF \\
\hline 30 & 3.5 & 30 & static & 1 & 111 & 0 & 78 & 29.8 & GF \\
\hline 0 & 4.4 & 30 & static & 4 & 132 & 0 & 100 & NA & ARC \\
\hline 30 & 4.4 & 30 & static & 4 & 132 & 0 & 62 & 8.8 & ARC \\
\hline 0 & 3.5 & 30 & static & 1 & 111 & 6 & 33 & 28.9 & GF \\
\hline 30 & 3.5 & 30 & static & 1 & 111 & 6 & 13 & 4 & GF \\
\hline 30 & 4.4 & 30 & static & 4 & 132 & 0.09 & 35 & 17.1 & ARC \\
\hline 30 & 4.4 & 30 & static & 4 & 132 & 0.24 & 26 & 26.9 & ARC \\
\hline NA & 3.5 & 30 & Moving ${ }^{1}$ & 1 & 111 & 0 & 102 & 20 & GF \\
\hline NA & 3.5 & 30 & Moving ${ }^{2}$ & 1 & 111 & 0 & 109 & 10.4 & GF \\
\hline 30 & 4.4 & 30 & Moving $^{3}$ & 4 & 132 & $0.09-0.024$ & 24.8 & 25 & ARC \\
\hline 0 & 3.5 & 60 & static & 1 & 141 & 0 & 100 & 12 & GF \\
\hline 30 & 3.5 & 60 & static & 1 & 141 & 0 & 48 & 33.1 & GF \\
\hline 0 & 4.7 & 60 & static & 1 & 282 & 0 & 93 & 11.1 & GF \\
\hline 30 & 4.7 & 60 & static & 1 & 282 & 0 & 48 & 33.2 & GF \\
\hline 0 & 4.4 & 30 & static & 4 & 174 & 0 & 62 & NA & ARC \\
\hline 0 & 3.8 & 25.1 & static & 4 & 95 & 0 & 95 & NA & ARC \\
\hline 0 & 5 & 34.9 & static & 4 & 174 & 0 & 36 & NA & ARC \\
\hline 0 & 4.18 & 28.5 & static & 4 & 120 & 0 & 74 & NA & ARC \\
\hline 0 & 4.62 & 31.5 & static & 4 & 145 & 0 & 54 & NA & ARC \\
\hline
\end{tabular}

${ }^{1}$ side to side movement; ${ }^{2}$ up and down movement; ${ }^{3}$ combined uncertainty based on direct observation of 20 cows $76 \%$ in feed bin, $16 \%$ out of feed bin and $8 \%$ above feed bin. 
Key to these findings are that increases in CV are due to increased random error (i.e. imprecision) and decreased systematic error (i.e. accuracy) and a decrease in CFG reflects a systematic error. Random errors caused by variable muzzle distance, air velocity and head movements can be reduced through the partitioning of variance into between-subject variance and within-subject variation. Systematic errors can be accounted for through statistical modelling, for example, including air velocity as a linear covariate or through a correction factor if compared to a gold standard. However, cow level systematic differences such as head lifting, which was reported by Huhtanen et al. (2015) to be highly repeatable $(0.74-0.82)$, or exhalation rate, which results in systematic differences between cows independent of $\mathrm{CH}_{4}$ production (Wu et al., 2018), cannot be accounted for through statistical measures. All of these sources of error will reduce the correlation between $\mathrm{CH}_{4}$ concentration and $\mathrm{CH}_{4}$ production from the high value we report in Table 6.1 ( $\mathrm{rp}=$ $0.95)$ and under the controlled conditions in Wu et al., (2018) $\left(R^{2}=0.97, r p=0.99\right)$. What can be seen from the $R^{2}$ reported under barn conditions in these studies is that the phenotypic correlation in the presence of repeated measures is, in practice, in the range of $(0.30-0.61)$. Unfortunately, neither study reported individual level correlations between $\mathrm{CH}_{4}$ production and $\mathrm{CH}_{4}$ breath concentration, so it is not possible to determine the correlation between $\mathrm{CH}_{4}$ production and $\mathrm{CH}_{4}$ breath concentration when random and systematic errors are accounted for in the best fitting statistical model.

In Chapter 2 we developed a cow head lifting algorithm which filters out data when the gas concentrations are no longer significantly different from background gas concentrations and no longer changing dynamically. This is a prediction of when the cow head has left the feed bin, but cannot account for the variation of muzzle position within the feed bin. We installed an NDIR gas sensor (sampling rate $1 \mathrm{~L} / \mathrm{min}$ ), comparable to that of Huhtanen et al., (2015), and a FTIR gas sensor (sampling rate $4 \mathrm{~L} / \mathrm{min}$ ), same as that of Wu et al. (2018), in a single feed bin of an AMS, applied the time alignment and cow head lifting algorithm and compared instruments. Significant systematic differences were observed in the means between instruments for both gases, likely due to differences in CFG due to different sampling rates. This systematic difference was corrected for by calibrating one of the instruments onto the other. We furthermore, modelled the repeated measurements per day and per week to remove associated random error. In the case of $\mathrm{CH}_{4}$ concentration, the intra-cow variation or imprecision decreased by more than $50 \%$ in both instruments from per visit to per day and more than $80 \%$ from per visit 
to per week. The repeatability estimates correspondingly increased from $t=0.38-$ 0.33 per AMS visit, to $t=0.58-0.51$ per day and $t=0.84-0.77$ per week for the NDIR and FTIR, respectively. These results show how increasing the number of records per cow can be an effective noise reduction method. However, the means remained largely unchanged and thus, systematic differences (i.e. decreased CFG) cannot be remedied through repeated measures. In principle, if we had run concentration recovery tests over each day of the experiment, it may have been possible to correct the drop in accuracy due to low and variable capture fractions, but repeatable cow factors like exhalation rates, would remain a source of bias. Regardless, the values of $\mathrm{CH}_{4}$ and $\mathrm{CO}_{2}$ breath concentrations per visit agreed sufficiently for interchangeable use $(\mathrm{CIA}=0.78$ and $\mathrm{CIA}=0.65)$. Regrettably, we did not report the CCC or individual level correlations in Chapter2, these were $\mathrm{rl}=0.70$ and $\mathrm{CCC}=0.69$ per visit for $\mathrm{CH}_{4}$ concentration. The individual level correlations from Chapter 3 for weekly $\mathrm{CH}_{4}$ concentrations where slightly lower than $\mathrm{CH}_{4}$ production $(0.75 \pm 0.20)$. Although the standard errors thereof are large, the correlation still indicates that $\mathrm{CH}_{4}$ breath concentrations are a good candidate as a large scale indicator trait for $\mathrm{CH}_{4}$ production in the $\mathrm{RC}$.

\subsubsection{Genetic variation in sniffer methane phenotypes}

Sniffer methane phenotypes have been dismissed off hand by many authors for the great variation (implied imprecision), inaccuracy or deviations in linear association from flux methods (Huhtanen et al., 2015; Goopy et al., 2016; Hammond et al., 2016; Hristov et al., 2018). For example, in their review Hammond et al. (2016) stated '...the need for high throughput methodology, e.g. for screening large numbers of animals for genomic studies, does not in itself justify the use of methods that are inaccurate, imprecise, or biased.'. Whilst the accuracy of the breeding values starts with the accuracy and precision of the phenotype, the validity of this statement is not absolute when applied to the specific use of sniffer $\mathrm{CH}_{4}$ phenotypes as large scale indicator traits for genetic evaluations. As demonstrated in Chapters 1-2, random bias or imprecision can be overcome through repeated measurements (see Text Box 1) and systematic bias or inaccuracy is of lesser importance as breeding values are centred (expressed relative to the base population with a mean of 0 ). As will be discussed below, slope or correlation bias (deviation from unity in linear association with the gold standard) can still be of use 
in a selection index, provided there is a linear genetic correlation significant from zero.

In Chapter 4, we find significant heritability estimates of $\mathrm{CH}_{4}\left(\mathrm{~h}^{2}=0.16-\right.$ $0.26)$ and $\mathrm{CO}_{2}\left(\mathrm{~h}^{2}=0.15-0.23\right)$ from repeated weekly records of breath concentrations in first parity cows in Denmark and The Netherlands. In Chapter 5 we report a heritability of $0.19 \pm 0.09$ for $\mathrm{CH}_{4}$ production using the $\mathrm{CO}_{2}$ ratio method from single weekly records of multiparous Danish Holstein cows, in line with the findings of others using this method $\left(h^{2}=0.21-0.25\right)$ (Lassen and Løvendahl, 2016; Zetouni et al., 2018). Using the individual level correlations estimated in Chapter 3, it is possible to estimate accuracy of breeding values for a bull with multiple daughter records (Figure 6.1). From Figure 6.1, it can be seen that the accuracy of bull EBVs fast approached 0.7 as the number of daughters with records exceeds 100 , which is practically feasible with the high throughput of sniffers installed in robotic milking herds. This assumes $\mathrm{CH}_{4}$ production in the $\mathrm{RC}$ is as heritable in lactating Holsteins on commercial mixed ration or grazing Holsteins using the $\mathrm{SF}_{6}$ method $0.33(0.15)$ (Breider et al., 2018) and our individual level correlations are reasonable predictors of the genetic correlations between sniffer and $\mathrm{RC} \mathrm{CH}_{4}$ emission. The resulting coheritability $\left(h_{x} \cdot h_{y} \cdot r x_{y}\right)$ is 0.19 using predicted $\mathrm{CH}_{4}$ production and 0.21 using $\mathrm{CH}_{4}$ breath concentrations, indicating considerable potential for sniffer $\mathrm{CH}_{4}$ phenotypes as large-scale indicator traits. In this instance, the slope or correlation bias which results in individual level correlations between sniffer phenotypes and $\mathrm{RC} \mathrm{CH}_{4}$ production deviating from 1 , does not preclude the use of sniffer phenotypes for breeding. However, this only demonstrates a proof of concept. Accurate estimates of genetic correlations between $\mathrm{CH}_{4}$ production in the $\mathrm{RC}$ and sniffer phenotypes, as well as all other traits currently included in the selection index, are needed before implementation can proceed with any certainty. Recording thousands of cows in RC requires a substantial financial investment and the largest deterrent is that $\mathrm{CH}_{4}$ production currently has no economic value, inhibiting the bio-economical modelling required to gauge the cost returns expected from selective breeding. This could be remedied by international collaborations to form a RC genomic reference population. Niu et al. (2018) recently collated RC data on 5,233 lactating dairy cattle, $68 \%$ of which are Holstein for phenotypic prediction equations, had all these cows been genotyped it would be feasible to estimate genetics correlations between the $\mathrm{RC}$ and other methods on genotyped Holstein populations. 


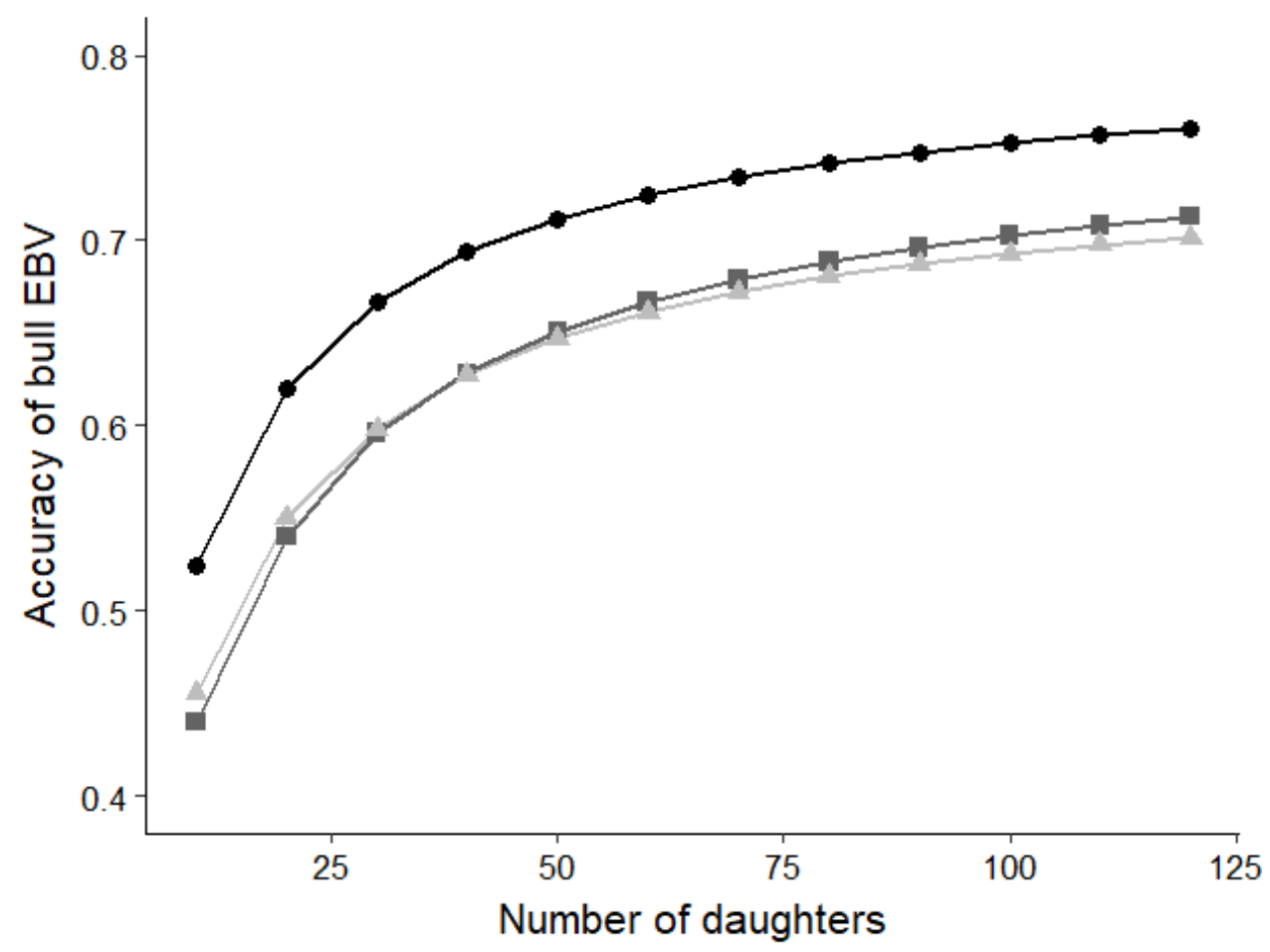

Figure 6.1. Accuracy of bull estimated breeding value (EBV) for $\mathrm{CH}_{4}$ production in the $\mathrm{RC}\left(\mathrm{h}^{2}=0.33\right)$, based on weekly averaged records for predicted $\mathrm{CH}_{4}$ production from sniffers $\left(h^{2}=0.19\right)$ (dark grey squares), $\mathrm{CH}_{4}$ breath concentration $\left(h^{2}=0.22\right)$ (light gray triangles) or both (black circles). Assuming $r_{g} \sim r_{1}$ and $r l=0.77$ for $\mathrm{CH}_{4}$ in $\mathrm{RC}$ and $\mathrm{CH}_{4}$ production from sniffers and $\mathrm{r}_{1}=0.75$ for $\mathrm{CH}_{4}$ production in the $\mathrm{RC}$ and $\mathrm{CH} 4$ concentration from sniffers.

\subsection{Genetic variation in feed efficiency of lactating cows}

Unlike $\mathrm{CH}_{4}$ emission, optimising feed utilisation in dairy cattle has a high economic value, but recording individual feed intake is challenging and costly and, thus, limits throughput to small research and specialised contract herds (Berry et al., 2014). As feed efficiency is not a directly observable animal metric, measuring feed efficiency relies on recording the feed intake and energy sinks and combining these into a single metric or index. In animal breeding, it has long been known that the most efficient index is a selection index based on genetic (co)variances and economic 
weights (Hazel, 1943). The implications of this are that appropriate weighting of DMI and energy sinks in the breeding goal will result in a genetic feed efficiency sub index, which requires records on $10^{4}-10^{5}$ animals (Veerkamp et al., 2013). However, for research purposes, a feed efficiency dependent variable is needed to determine the correlations between feed efficiency and other traits, as well as gauge responses to different interventions.

In its simplest form, feed efficiency can be defined as RFI, where DMI is regressed on multiple energy sinks in a multiple regression model and the resulting random residuals (RFI) are the feed efficiency phenotype analysed in an animal model (two-step RFI)(Koch et al., 1963). This method requires suitably large numbers of simultaneous records of DMI and energy sinks to accurately estimate the phenotypic regression coefficients. An extension of this model is to include the random additive genetic effects of animal directly into the multiple regression (single step RFI), which has been shown to be genetically correlated to two step RFI (0.80 0.991) (Savietto et al., 2014; Tempelman et al., 2015). An advantage of both methods is that heterogeneity in regression coefficients due to different diets or stages of lactation, can be accounted for by including a regression by diet or lactation stage interaction term (Tempelman et al., 2015; Li et al., 2017). A disadvantage of both methods is that by defining phenotypic correlation coefficients, RFI is phenotypically independent of energy sinks, but genetic correlations remain and, thus, correlations to other traits are not representative (Huttmann et al., 2009; Spurlock et al., 2012). A further disadvantage of the single step model is that we cannot estimate genetic correlations between single step RFI and DMI in a multitrait model due to collinearity problems, making estimating the correlated response to selection for DMI impossible.

Kennedy et al. (1993) demonstrated a method using selection indices for estimating regression coefficients from (co)variances, post-hoc from multitrait models, which include DMI and energy sinks. By defining a restricted gains index of DMI conditional on the genetic (co)variances with energy sinks, it was possible to define RFI genetically independent of energy sinks (RFIg). Under the specific set of circumstances where the genetic partial regression coefficients are equivalent to the phenotypic partial regression coefficients, RFIg will be equivalent to phenotypic RFI models. A further advantage of this approach is that sparsely recorded energy sinks are not excluded from the model analyses. A disadvantage is that large numbers of records are required to accurately estimate genetic (co)variances. Furthermore, heterogeneity of partial regression coefficients due to different rations cannot be 
estimated outside of the more cumbersome hierarchical Bayesian structural equation modelling (Lu et al., 2016).

In Chapter 4, we estimate gRFI for first parity lactating Holstein cattle in Denmark $\left(h^{2} 0.15 \pm 0.04\right)$ and The Netherlands $\left(h^{2} 0.17 \pm 0.03\right)$ and the combined country dataset ( $h^{2} 0.15 \pm 0.04$ ), confirming that gRFI is significantly heritable (Lu et al., 2015). However, defining gRFI in Denmark with 813 cows, with 29084 weekly records, was challenging, as can be seen from the standard errors on the genetic correlations with component traits DMI $(0.21 \pm 0.64)$, ECM $(0.002 \pm 0.58)$ and live weight $(0.004+0.71)$. The Netherlands had 2112 first parity cows with 39,464 average weekly records for $\mathrm{DMI}$, which reduced the uncertainty around the genetic correlations with DMI $(0.74 \pm 0.06), \operatorname{ECM}(0.00 \pm 0.15)$ and live weight $(0.00 \pm 0.11)$. Whilst, historical data, different experimental rations and different lactation stages can contribute to the heterogeneity of genetic partial regression coefficients and, thus, the standard errors of genetic correlations, these are two of the largest DMI datasets in the world at present. This implies that to define gRFI in practice, substantially larger numbers of cows are required to obtain more current and homogenous data. These results do lend confidence to the notion that breeding for increased metabolic efficiency is possible in lactating dairy cattle and these parameters can be utilized to estimate the cost benefit of large scale recording of DMI under commercial conditions. An important consideration is that we only estimate gRFI as a measure of metabolic efficiency during the first lactation, recognising that the productive life of cows spans multiple lactations and the life time efficiency spans lactating, growing and dry periods. In this respect, a considerable portion of the cow's life span is largely ignored; considerable efforts are required to define feed efficiency during all lifetime stages to truly increase the profitability and sustainability of the dairy industry. Regardless, metabolic efficiency during the first lactation is a logical first step in this progression.

To this end, new developments in the field of image analysis technology, providing an opportunity for the volumetric analysis of feed intake on dairy cows under commercial barn conditions, are promising. This technology is still under development, however, initial results show image analysis individual identification of cows show a sensitivity of $95 \%$ and specificity of 95\% (Thomasen et al., 2017), which are comparable to current automated feeding systems reviewed in the general introduction. In a pilot study conducted over 14 days in a commercial Jersey barn in Denmark, Lassen et al. (2018) was able to obtain daily DMI ( $t=0.65$ ) and weekly averaged DMI $(t=0.84)$, which are directly comparable to those found in 
Danish Jerseys used in automated feed bins in a research barn (Li et al., 2016). Although further validation of this technology is required, it poses a significant opportunity to increase the throughput of feed intake recording and, thus, feed efficiency throughout a cow's life.

\subsubsection{The relationship between Feed efficiency and $\mathrm{CH}_{4}$ emissions}

As $\mathrm{CH}_{4}$ emission currently has no economic value but, is estimated to constitute a loss of energy from the cow (2-12\%) of gross energy intake (Johnson and Johnson, 1995), many have suggested that improving feed efficiency will concomitantly improve $\mathrm{CH}_{4}$ emissions (Beauchemin et al., 2008; Waghorn and Hegarty, 2011; Lassen and Løvendahl, 2016). It follows that, since $\mathrm{CH}_{4}$ production in the RC is directly proportional to DMI (Yan et al., 2010), breeding cows which eat less DMI, for contemporary levels of ECM and BW (the very definition of feed efficiency), will reduce $\mathrm{CH} 4$ production. A counter argument is that increased diet digestibility (D) reflects the inherent ability of ruminants to transform ingested feed into metabolisable energy. Digestibility has been shown to be repeatable $(t=0.28-0.37)$ in dairy cattle (Huhtanen et al., 2015; Cabezas-Garcia et al., 2017). However empirical modelling evidence shows that $D$ is a function of rate of digestion $(k d)$ and rate of passage $(k p): D=k d /(k d+k p)$. Since $k d$ is feed, specific and independent of the animal, only $\mathrm{kp}$ can influence digestibility. It follows that decreasing $\mathrm{kp}$, will increase $D$, increasing feed efficiency but also increasing $\mathrm{CH}_{4}$ emissions. Furthermore, studies in sheep divergent for $\mathrm{CH}_{4}$ yield ( $\left.\mathrm{CH} 4 / \mathrm{DMI}\right)$, show that high emitters had significantly higher digestibility (Pinares-Patiño et al., 2011). Unfortunately, the authors did not compare $\mathrm{CH}_{4}$ production in absolute terms and instead chose a ratio trait as their response variable.

As has been discussed previously herein, adequate high throughput phenotyping of traits required for estimating feed efficiency and $\mathrm{CH}_{4}$ production with the $\mathrm{RC}$ is challenging. As a result, inconsistent definitions of feed efficiency are used, often with alternative methods of recording $\mathrm{CH}_{4}$ emissions on a small scale at the phenotypic level. Furthermore, feed efficiency phenotypes and $\mathrm{CH}_{4}$ emission phenotypes are often expressed as ratios, the limitations of ratios in terms of their non-linear relationships between the actual ratio and it's component traits and the narrow range of parameters where these correlations are linear are discussed elsewhere (Sutherland, 1965; Veerkamp and Emmans, 1995). Not surprisingly, defining the relationship between feed efficiency and $\mathrm{CH}_{4}$ emissions in dairy cattle has been inconsistent. A favourable phenotypic correlation was detected between 
$\mathrm{RFI}$ and $\mathrm{CH}_{4}$ production ( $r_{p}=-0.55$ ) in Angus cattle on pasture using the GF (Velazco et al., 2017). No relationships where detected between $\mathrm{RFI}, \mathrm{CH}_{4}$ yield of $\mathrm{CH}_{4}$ intensity in lactating Holstein, Simmental and Jerseys cows fed forage diets in the RC (Münger and Kreuzer, 2008). No differences in $\mathrm{CH}_{4}$ production or $\mathrm{CH}_{4}$ yield was detected on non-lactating Holstein-Friesians divergent for RFI, fed alfalfa cubes in the RC (Waghorn and Hegarty, 2011). Unfavourable relationships were found between RFI and $\mathrm{CH}_{4}$ production in beef heifers on feedlot, recorded using RC (Montanholi et al., 2016). However, all of these studies had limited numbers of cows (16 - 39).

Studies using $\mathrm{CH}_{4}$ production estimated from metabolisable energy intake yielded favourable correlations between feed efficiency and $\mathrm{CH}_{4}$ production. de Haas et al., (2011) estimated $\mathrm{CH}_{4}$ production from MEl in 665 first parity Holstein-Friesian cows and found RFI to be favourably correlated both phenotypically $\left(r_{p}=0.72\right)$ and genetically $\left(r_{g}=0.38\right)$ to $\mathrm{RFI}$. In 429 lactating Nordic red cattle, $\mathrm{CH}_{4}$ production was estimated using sniffers and the $\mathrm{CO}_{2}$ ratio method, with predicted $\mathrm{CO}_{2}$ tracer gas estimated from $\mathrm{MEI}$, and found that the phenotypic correlation between residual energy intake (REI) (similar to RFI except energy intake is used in place of DMI) and $\mathrm{CH}_{4}$ production was favourable $\left(r_{p}=0.60\right)$ (Negussie et al., 2014). In the same study, the ratio of ECM/EI was also favourably correlated $\left(r_{p}=-0.62\right)$, both ratio and residual traits indicating that more efficient cows will produce less $\mathrm{CH}_{4}$ in absolute terms. However, the phenotypic correlation between $\mathrm{REI}$ and $\mathrm{CH}_{4}$ yield $\left(r_{p}=0.38\right)$ indicates that more efficient animals produce more $\mathrm{CH}_{4}$ production per kilogram of energy intake. This finding could potentially reconcile the two opposing arguments about feed efficiency and $\mathrm{CH}_{4}$ emissions, where more efficient animals produce less total $\mathrm{CH}_{4}$, but more $\mathrm{CH}_{4}$ per unit of feed intake through increased digestion. However far larger studies are required to confirm this on a genetic level. For instance, Breider et al (2018) estimated genetic parameters for $\mathrm{DMI}, \mathrm{MY}, \mathrm{BW}$ and $\mathrm{CH}_{4}$ production $\left(\mathrm{SF}_{6}\right.$ method) in 314 Holstein cows on pasture. The restricted gains index for decreasing DMI, whilst maintaining MY and BW (definition of gRFI) showed a predicted correlated increase in $\mathrm{CH}_{4}$ production. In Chapter 4, we applied the methods described by Kennedy et al. (1993) and found $r_{g}=-0.004$ between gRFI and $\mathrm{CH}_{4}$ production.

In Chapter 4, we estimated genetic parameters for gRFI and $\mathrm{CH}_{4}$ concentration from the sniffers directly, but found non-significant negative genetic correlations in Denmark $\left(r_{\mathrm{g}}=-0.17 \pm 0.85\right)$ and The Netherlands $(-0.52 \pm 0.32)$. This could, in part, be due to difficulties in acquiring adequate numbers of cows to define gRFI and estimate genetic correlations with $\mathrm{CH}_{4}$ concentration. However, in the 
combined population dataset we found a significant favourable genetic correlation $\left(r_{g}=0.33 \pm 0.15\right)$. The change of sign from positive to negative in the genetic correlation in combined population could be due to increased numbers of records. It could, however, also be an artefact of population heterogeneity in genetic partial regression coefficients or other unknown factors, like genotype by environment interactions. Further work is needed to validate these results, either through alternative modelling strategies for RFI, or increased within country records for both traits. In the absence of a genetic correlation between $\mathrm{CH}_{4}$ concentration and $\mathrm{CH}_{4}$ production in the $\mathrm{RC}$, it is not possible to infer the relationship between gRFI and $\mathrm{CH}_{4}$ production. What is clear, regardless of the sign of the genetic correlations, is that from their magnitude in all datasets, $\mathrm{CH}_{4}$ concentration is a potential large-scale indicator trait for gRFI. Therefore, there is an economic incentive to record $\mathrm{CH}_{4}$ concentrations until a genetic correlation with $\mathrm{CH}_{4}$ production using the gold standard method is forthcoming.

\subsection{Genetic variation in the rumen microbiome of lactating cows}

In Chapter 5, we investigated both the genetic variation in rumen bacteria and archaea relative abundance and composition to assess the level of host genetic control on the rumen microbiome. At the individual OTU level, we identified 3,894 bacteria and 189 archaea present in at least $50 \%$ of the cows. From these, 4083 animals models were run and we found $6 \%$ of the rumen bacteria were significantly heritable $\left(h^{2} 0.16-0.44\right)$ and $12 \%$ of the archaeal OTUs were significantly heritable $\left(h^{2} 0.18-0.33\right)$. These results provide evidence from a good-sized cohort of cattle for host additive genetic effects on the rumen microbiome. However, the number of significantly heritable OTUs is alarmingly close to what would be expected under the null hypothesis. Although, it is not common practice for heritability estimates, we set a false discovery rate of $15 \%$ and none of the OTUs tested, passed this. This could, in part, be due to the sheer number of OTUs tested, many of whom are not heritable and are, relatively speaking, low number of cows $(n=750)$.

There are limited heritability estimates for rumen microbes from which to draw comparisons. Sasson et al., (2017) assessed the heritability of relative abundance of rumen bacteria in 47 genotyped Holsteins, and found 22 out of 85255 OTUS to be significantly heritable $\left(h^{2}>0.70\right)$. These estimates are considerably higher than our own, however, heritability estimates are notoriously biased in small numbers of cows. The same authors reported in their supplementary material a 
significant heritability of 1 for DMI and RFI, 0 from milk yield (Sasson et al., 2017). Conversely, there is a wealth of literature on heritability of gut microbes in monogastrics. In 412 pairs of humans twins, Goodrich et al. (2014) found 5.3\% of 909 OTUs to be significantly heritable ( $\left.h^{2} 0.20-0.35\right)$, and in a follow up study with 1126 pairs of twins, $8.8 \%$ of 945 OTUs where found to be significantly heritable $\left(\mathrm{h}^{2} 0.15\right.$ 0.42) (Goodrich et al., 2016). From these results, the authors conclude that human genetics shape the gut microbiota. In a study with 207 pigs, Camarinha-silva et al., (2017) found 8 genera out of 49 to be significantly heritable $\left(h^{2} 0.32-0.52\right)$. Although the gastro-intestinal tract of monogastrics and ruminants are vastly different, these results together do suggest that a portion of the gut microbiota are heritable and, are thus, influenced by host genetic composition. In both cases, the host is heavily reliant on the activity of microbes for the derivation of energy from feed, a crucial requirement for survival. It is, thus, in the host's best interest to provide an environment suitable for microbes which fulfil key digestive processes. As discussed by Shapira, (2016), evolutionary processes rarely leave biological pathways essential to survival up to chance.

The variation in the rumen microbiome can be partitioned into other sources of host variation, other than additive genetics. If repeated measures are available, it is possible to partition phenotypic variation into permanent environmental effects of host (also called general environment) and residual variation (also called special environment)(Falconer and Mackay, 1996). If repeated measures are made over very short periods of time, such that underlying biology has not changed, then the residual variation is 'method imprecision', as discussed in previous sections of this thesis. The permanent environment includes host additive genetics, non-additive genetics, maternal effects, common environmental effects and other host traits, like learnt behaviour. The permanent environment expressed as a proportion of the total variation is the repeatability, as mentioned in previous sections of this thesis. In a subset of 57 cows from Chapter 5 , we had repeated rumen samples 122 days apart, on the same diet, and ran repeatability animal models at the genus level (Zhu, 2016). We combined this with the genus level heritability estimates reported in Chapter 5 for comparison in Figures 6.2-6.3 below. Importantly, the repeatability estimates are a measure of persistence of ranking between cows through time, which had considerable range $(t=0-0.80)$. $\mathrm{A}$ proportion of genera $11.2 \%$ were not repeatable $(t=0)$, indicating the host explains no variation in their abundance and $12 \%$ has $t<0.50$, indicating more than $50 \%$ of the variation in their abundance was explained by host. 


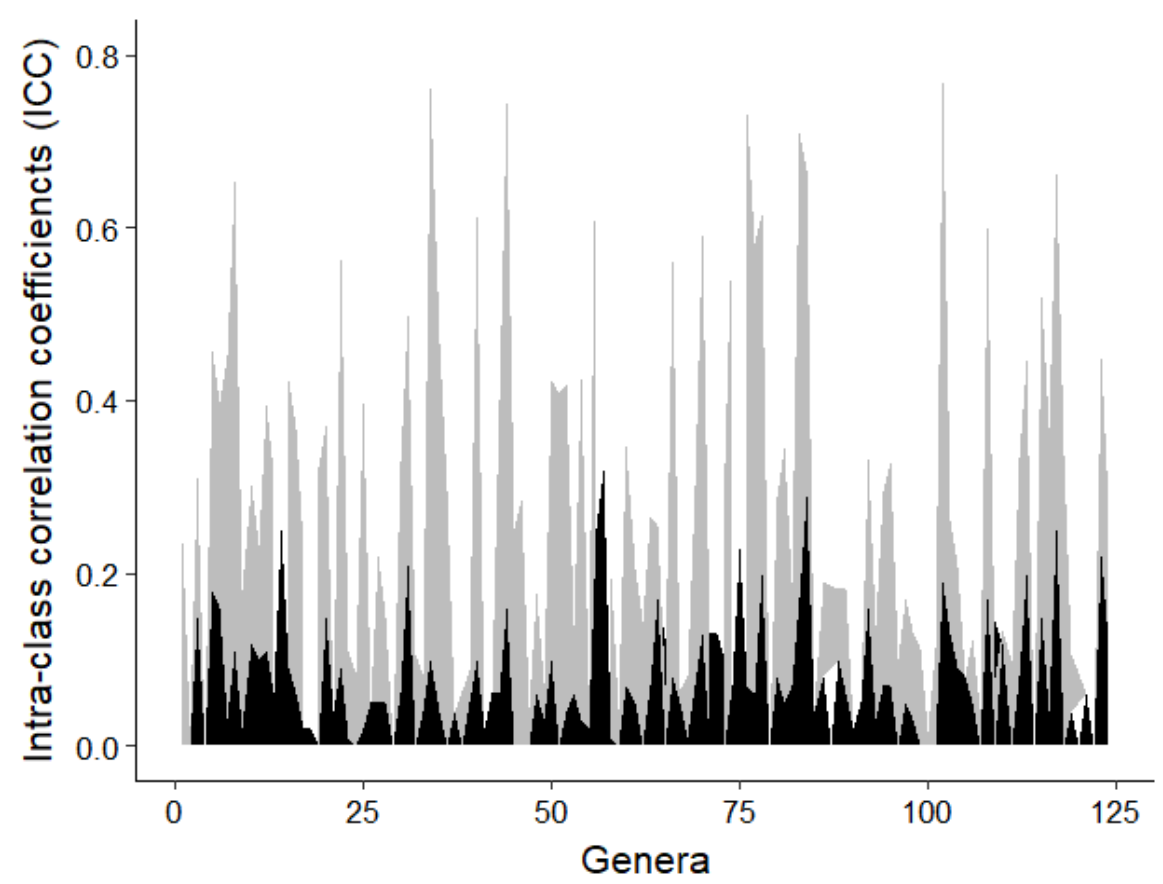

Figure 6.2 Intraclass correlations coefficients for rumen genera, repeatability (Grey) for 5 repeat sampled Holsteins and Heritability (Black) for 750 single sampled Holsteins.

From Figure 6.3 there is a general positive trend between magnitude of repeatability and heritability, although for some genera they were repeatable but not genetic and vice versa this is partly due to the smaller sample size with repeated measurements as $t=0$ and $h^{2}<0$ is not possible in practice. Similar results were reported for human gut microbiota using the intra class correlation coefficient (ICC) between pairs of dizygotic and monozygotic twins and heritability estimates (Goodrich et al., 2014, 2016). This ICC between identical twins is equivalent to the repeatability from repeated measures, however, the ICC between dizygotic twins reflects shared common and maternal effects (the difference between ICC for monozygotic twins and dizygotic twins is half the additive genetics). Together, these results indicate that the host does influence the abundance of certain rumen microbiota and that additive genetics is one of the contributing host effects. Further work and samples from larger numbers of cows are required to assess the effects of maternal and common environmental effects. 


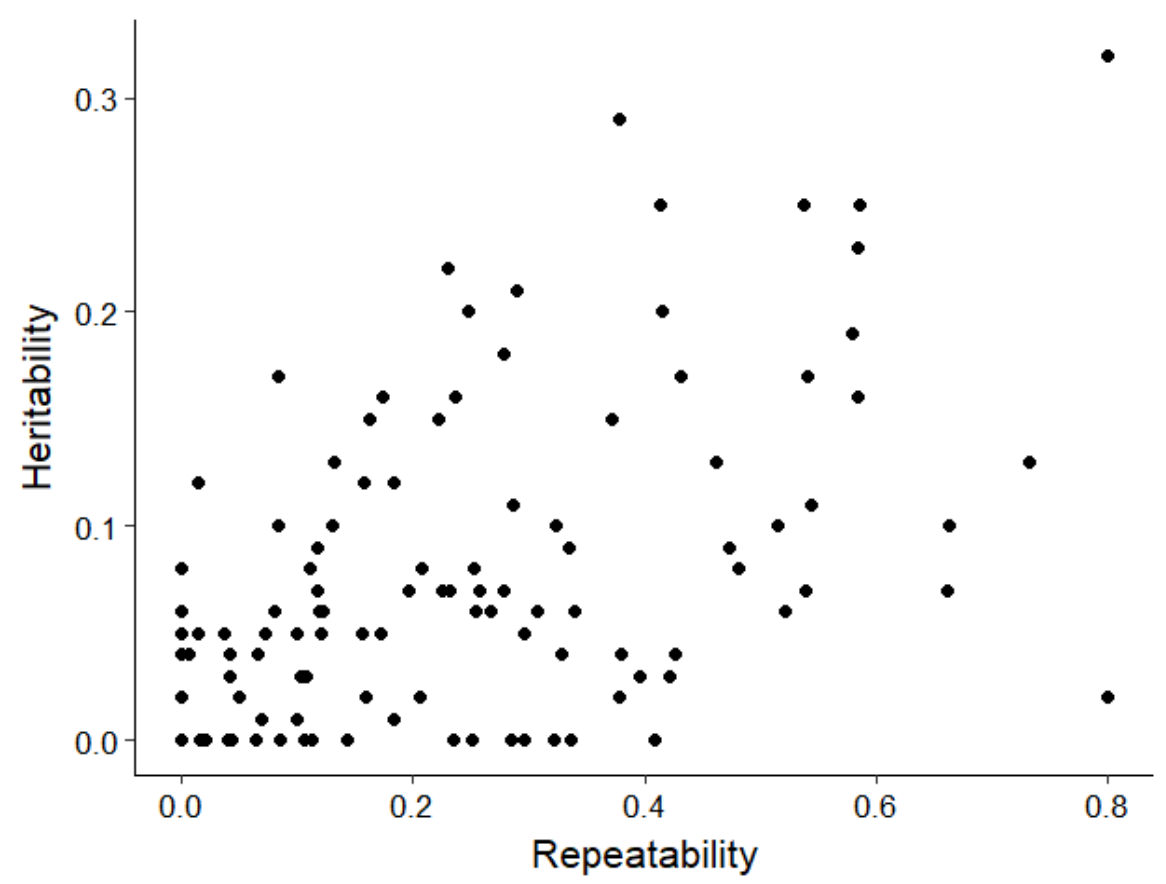

Figure 6.3 Repeatability of rumen genera in 57 Holsteins cows against the heritability of rumen genera in 750 Holstein cows.

\subsubsection{Genetic variation in rumen bacterial and archaeal abundance}

Some authors have subsequently challenged the notion that the relatively small proportion of heritable microbes can truly shape the entire community composition. For instance, Rothschild et al. (2017) weighted the heritability estimates of Goodrich et al. (2016a) by their relative abundance to estimate heritability of the entire microbiome and found $1.9 \%-8.1 \%$, depending on the use of a false discovery rate threshold for heritability estimates. For our dataset, the respective weighted average heritability of the rumen bacteria and archaea from Chapter 5 was $10.9 \%$. However, simply weighting the heritability by relative abundance assumes all microbiota are of equal functional importance and do not interact with each other.

Examining microbial community composition through multidimensional scaling, such as principal coordinate analysis or beta diversity, has identified stratified clusters in humans referred to as 'enterotypes' (Arumugam et al., 2013) and ruminants referred to as 'ruminotypes' (Kittelmann et al., 2014). Diversity 
estimates are used in microbial ecology to assess the diversity within samples (alpha diversity) and between samples (Beta diversity). These clusters found using beta diversity, are thought to represent altered host-microbial states (Arumugam et al., 2013) and in the case of sheep, one of the clusters was associated with smaller rumen size, high rumen passage rate and lower $\mathrm{CH}_{4}$ emissions (Kittelmann et al., 2014). In Chapter 5, we investigated ruminotypes in 750 Holstein cattle and found clustering, which was partly explained by non-genetic host parameters, like lactation stage and parity, technical factors, like sequence batch and environmental variables, like herd. However, the largest sources of variation was additive genetics $\left(h^{2} 0.20-\right.$ 0.39). These findings suggest that host additive genetics influences the rumen microbial communities to a larger extent than was suggested using the average heritability. It is important to note that clustering methods are data set specific and are, thus, affected by population and environmental heterogeneity. In our study, the herds were selected partly for similar management and dietary regimes, as well as breed uniformity (Danish Holsteins), to minimize these potential sources of variation. In the UK, in the human twins dataset, Goodrich et al., (2016) investigated different alpha and beta diversity metrics and found strong correlations between heritable microbiota, as well as host SNPs with diversity measures, indicating heritable microbes and host genetics influences community structures. Conversely, in a study with 1142 genotyped individuals in Israel from diverse genetic backgrounds (grandparents originating from 72 different countries), Rothchild et al, (2017) failed to detect a heritable component to gut microbial diversity estimates or significantly associated SNPs. Thus, it is important to consider the genetic and environmental heterogeneity when assessing their relative contributions to microbial communities, as both sources are associated with microbial variations.

\subsubsection{Genetic variation in rumen bacterial and archaeal community composition}

As genetic variation in $\mathrm{CH}_{4}$ production and rumen microbes is detected in Chapter 5 and methanogenic archaea and bacteria are directly responsible for $\mathrm{CH}_{4}$ production, a logical progression is to investigate associations between rumen microbiota and $\mathrm{CH}_{4}$ production. We ran a microbiome wide association study (MWAS) for OTUs and genera against $\mathrm{CH}_{4}$ production, whilst simultaneously controlling for familial relationships and non-genetic factors, and found eight genera to exceed an FDR threshold of $15 \%$. Of these eight, four were found to be affected by methane inhibitors or be associated with the production of methanogenic 
substrates; none were archaea, further strengthening the hypothesis that bacteria drive $\mathrm{CH}_{4}$ production through methanogenic substrate production. Of the eight, three were found to be moderately heritable $\left(h^{2} 0.17-0.20\right)$, a positive indicator that breeding or rumen microbial abundance could result in changes to $\mathrm{CH}_{4}$ production, but genetic correlations from larger datasets are required to confirm this. Single OTU or genera associations fail to capture the complexity of microbial communities, so we also investigated associations between community structure and $\mathrm{CH}_{4}$ production and found the first principal component of both bacterial and archaeal beta diversity significantly associated with $\mathrm{CH}_{4}$ production, indicating there is an optimal rumen microbial community composition for $\mathrm{CH}_{4}$ production.

Due to the moderate heritability estimates of rumen microbiota and $\mathrm{CH}_{4}$ production, as well as the detection of heritable and non-heritable rumen microbiota associated with $\mathrm{CH}_{4}$ production, it was necessary to quantify the relative contributions of rumen microbiota and host genetics to variation in $\mathrm{CH}_{4}$ production simultaneously. To do this, we create a microbial kinship matrix, analogous to genomic or pedigree relationship matrices used in the estimation of heritability. We defined microbiability $\left(\mathrm{m}^{2}\right)$ as the proportion of phenotypic variance due to rumen microbial kinship, in analogy to heritability. As with heritability, microbiability is narrow sense, in that it does not account for microbe-microbe interactions or microbe-environment interactions. In Chapter 5, we found significant microbiability of $\mathrm{CH}_{4}$ production $\left(\mathrm{m}^{2}=0.15\right)$ comparable to that of heritability $\left(\mathrm{h}^{2}=0.19\right)$. Crucially, when comparing these two sources of variation, first separately and then jointly, we found minor changes to the estimates, indicating that in the case of $\mathrm{CH}_{4}$ production, the two sources are largely independent. This implies that selection for microbes associated with $\mathrm{CH}_{4}$ production may have limited impact, as the majority of the variation in $\mathrm{m}^{2}$ is due to rumen microbiota less influence by the host genetics and vice versa. This also opens up the possibility for a largely under exploited source in host variation.

\subsubsection{Prospective for using rumen microbiota to obtain desired changes in the host phenotype}

It is proposed in the general introduction that the successful symbiosis due to coevolution of ruminant and rumen microbiome suggests that both be viewed together as a single unit (i.e. as a holobiont). It was discussed how ignorance of the microbial contribution to host phenotypes can result in suboptimal or unpredictable response, as was seen by rapid microbial adaption to methanogenic inhibiting 
additives. For traits of interest, we propose determining the microbiability through the use of microbial relationship matrices derived from OTUs, full metagenomic or transcriptomic sequences to quantify the microbial association with host phenotypic variation. If a trait of interest is not associated with the microbiome, further exploration of the rumen microbiome is not needed. However if a trait of interest is associated with the rumen microbiome it is necessary to determine the relative independence from diet or the host additive genetics. Particularly, the genetic correlations between associated microbiota and the host trait of interest to ensure unwanted correlated responses to selection in the rumen microbiome are not realized. Conversely, if genetic correlations are sufficiently greater than 0 there is a potential to incorporate rumen microbial phenotypes into the selection index as indicator traits to improve the accuracy of selection and thus the response.

By estimating the microbiability we determined that differences in the rumen microbiome are associated with differences in the host $\mathrm{CH}_{4}$ production. Furthermore, some of the specific rumen microbiota are likely under the influence of host additive genetics, but to a large extent the two are independent. In the case of $\mathrm{CH}_{4}$ production where the two sources are largely independent, selective breeding is one method to reduce $\mathrm{CH}_{4}$ emissions but this will not fully exploit the variation observed due to the rumen microbiome and will take generations to illicit a response. Better understanding of whether microbiability is causative or merely coassociated with differences in the host $\mathrm{CH}_{4}$ production and other traits are needed. One potential method is to inoculate cows with poor microbial estimated values (random solutions from microbiability models) with the rumen contents of cows which have favourable microbial estimated values and assess the response in host $\mathrm{CH}_{4}$ production. Inoculation of cattle with the cud of healthy donor cows has long been an effective and rapid treatment of cows with digestive or metabolic disorders (DePeters and George, 2014). This is an example of using rumen microbiota to affect a desired change to the host cow phenotype. Recent work with repeated inoculation of beef heifers with bison rumen contents altered the rumen microbiome and metabolic activity eliciting increased protein and nitrogen retention on a nutritionally poor straw diet (Ribeiro et al., 2017). Another example is the discovery of Synergistes jonesii in goats which conveys the ability of the host to degrade the otherwise toxic pyridinediol compounds from the fodder plant Leucaena leucocephala, which was successfully conveyed to Australian beef cattle and sheep (Graham et al., 2013). Both of these examples demonstrate the rapid adaption of 
host to dietary changes acquired through the incorporation of beneficial microbes into the rumen community.

\subsection{Conclusions and Recommendations:}

The aims of this thesis where to improve and validate the high throughput non-invasive sniffer method of recording $\mathrm{CH}_{4}$ emissions under commercial conditions. Furthermore, to investigate the genetic relationships between $\mathrm{CH}_{4}$ emission, feed efficiency and the rumen microbiome. Through instrument comparisons and validation, sources of error in sniffer $\mathrm{CH}_{4}$ emission phenotypes were identified and where possible corrected. The resulting $\mathrm{CH}_{4}$ production and $\mathrm{CH}_{4}$ breath concentration phenotypes were found to be significantly heritable but were low-moderately in agreement at the phenotypic level with $\mathrm{RC} \mathrm{CH}_{4}$ production. However, the individual level correlations (as proxies for genetic correlations) between sniffer $\mathrm{CH}_{4}$ emission phenotypes were high $(0.75-0.77)$ demonstrating the value of sniffer $\mathrm{CH}_{4}$ emission phenotypes as large scale indicator traits in a selection index for reduced $\mathrm{RC} \mathrm{CH}_{4}$ production.

Feed efficiency was found to be significantly heritable in first parity Holsteins in Denmark and The Netherlands. Furthermore favourable genetic correlations where estimated between $\mathrm{CH}_{4}$ breath concentration and feed efficiency, to this sniffer $\mathrm{CH}_{4}$ emission phenotypes can be of use as large scale indicator traits. A proportion of the relative abundance of the rumen bacteria and archaea where found to be heritable, demonstrating the host additive genetics can influence the rumen microbiome. Some heritable bacterial genera where found to be significantly associated with $\mathrm{CH}_{4}$ production, but the majority of variation in $\mathrm{CH}_{4}$ production explained by rumen microbial composition was largely independent of host additive genetics. The aims of this thesis were largely met; however, caveats and future research considerations remain.

The first priority for improving the profitability and sustainability of the dairy industry is the development of a life-time metabolic and maintenance efficiency index. The single most limiting factor to breeding for more feed efficient cattle is an accurate, precise, non-invasive, cost effective and high throughput method of recording feed intake in dairy cattle under commercial conditions. Small research studies have demonstrated proof of concept in genetic variation for metabolic and maintenance efficiency during lactation. Until methane production has a direct economic or societal value, its value to the farmer will lie in being an 
indicator trait for feed intake and feed efficiency. To this end, the sniffer method shows considerable promise, but any further development to the method that increases accuracy and precision without compromising through put and noninvasiveness, will be of value to improving accuracy of EBVs. Should $\mathrm{CH}_{4}$ production get an economic or societal value, obtaining genetic correlations with meaningful standard errors between RC and sniffers will be crucial to their use as a large scale indicator trait for $\mathrm{CH}_{4}$ production. Simulations show combining genomic information with feed efficiency records (and likely $\mathrm{CH}_{4}$ production as well) on 4000 cows a year will yield adequate genomic prediction accuracies to obtain genetic responses for these traits (Wallén et al., 2017). With considerable investment, these numbers are achievable in the $\mathrm{RC}$, which will yield meaningful genetic correlations between feed intake, efficiency, production traits and $\mathrm{CH}_{4}$ production within the $\mathrm{RC}$ and other traits under commercial conditions like sniffer breath concentration measures. The first breeding company to publish EBVS for these traits will have a competitive advantage which must be considered in cost benefit analyses.

Further work is needed in linking rumen microbial associations to causation. Whilst some rumen microbes are heritable their cost and throughput limits their use as indicator traits for already costly and limiting breeding goal traits like $\mathrm{CH}_{4}$ production and feed efficiency. Estimating microbiability and estimated microbial values for host phenotypes is the first step to identifying desirable rumen microbial communities associated with host phenotypes. However, validation of transmittable desired changes to host phenotypes through transfaunation and inoculation is still required. This could be investigated by in vitro batch fermentation studies before attempting in vivo investigations. Should improved feed efficiency and $\mathrm{CH}_{4}$ production prove transmittable through inoculation with rumen contents from donor animals this could open up new possibilities for directing rapid changes to host phenotypes using quantitative genetics methods to identify optimal microbial communities.

\section{References}

Adolph, S.C., and J.S. Hardin. 2007. Estimating phenotypic correlations: Correcting for bias due to intraindividual variability. Funct. Ecol. 21:178-184. doi:10.1111/j.1365-2435.2006.01209.x.

Arumugam, M., J. Raes, E. Pelletier, D. Le Paslier, J. Batto, M. Bertalan, N. Borruel, and F. Casellas. 2013. Enterotypes of the human gut microbiome. Nature 473:174-180. doi:10.1038/nature09944.Enterotypes.

Barnhart, H.X., M.J. Haber, and L.I. Lin. 2007a. An overview on assessing agreement 
with continuous measurements.. J. Biopharm. Stat. 17:529-569. doi:10.1080/10543400701376480.

Barnhart, H.X., Y. Lokhnygina, A.S. Kosinski, and M. Haber. 2007b. Comparison of concordance correlation coefficient and coefficient of individual agreement in assessing agreement. J. Biopharm. Stat. 17:721-38. doi:10.1080/10543400701329497.

Beauchemin, K.A., M. Kreuzer, F. O'Mara, and T.A. McAllister. 2008. Nutritional management for enteric methane abatement: A review. Aust. J. Exp. Agric. 48:21-27. doi:10.1071/EA07199.

Berry, D.P., M.P. Coffey, J.E. Pryce, Y. de Haas, P. Løvendahl, N. Krattenmacher, J.J. Crowley, Z. Wang, D. Spurlock, K. Weigel, K. Macdonald, and R.F. Veerkamp. 2014. International genetic evaluations for feed intake in dairy cattle through the collation of data from multiple sources.. J. Dairy Sci. 97:1-12. doi:10.3168/jds.2013-7548.

Bijma, P., and J.W.M. Bastiaansen. 2014. Standard error of the genetic correlation: how much data do we need to estimate a purebred-crossbred genetic correlation?. Genet. Sel. Evol. 46:79. doi:10.1186/s12711-014-0079-z.

Breider, I.S., E. Wall, P.C. Garnsworhty, and J.E. Pryce. 2018. Genetic relationships between methane emission and milk yield, live weight and dry matter intake. Page in Proceedings of the World Congress on Genetics Applied to Livestock Production, 11.

Cabezas-Garcia, E.H., S.J. Krizsan, K.J. Shingfield, and P. Huhtanen. 2017. Betweencow variation in digestion and rumen fermentation variables associated with methane production. J. Dairy Sci. 100:4409-4424. doi:10.3168/jds.201612206.

Camarinha-silva, A., M. Maushammer, R. Wellmann, M. Vital, and S. Preuss. 2017. Host genome influence on gut microbial composition and microbial prediction of complex traits in pigs. Genetics 206:1637-1644. doi:10.1534/genetics.117.200782/-/DC1.1.

DePeters, E.J., and L.W. George. 2014. Rumen transfaunation. Immunol. Lett. 162:69-76. doi:10.1016/j.imlet.2014.05.009.

Dingemanse, N.J., and N.A. Dochtermann. 2013. Quantifying individual variation in behaviour: mixed- effect modelling approaches. J. Anim. Ecol. 39-54. doi:10.1111/1365-2656.12013.

Downs, C.J., and N.A. Dochtermann. 2014. Testing hypotheses in ecoimmunology using mixed models: Disentangling hierarchical correlations. Integr. Comp. Biol. 54:407-418. doi:10.1093/icb/icu035.

Falconer, D., and T. Mackay. 1996. Introduction to Quantitative Genetics. Fourth edi. Longman Scientific and Technical, Essex.

Gardiner, T.D., M.D. Coleman, F. Innocenti, J. Tompkins, A. Connor, P.C. Garnsworthy, J.M. Moorby, C.K. Reynolds, A. Waterhouse, and D. Wills. 2015. Determination of the absolute accuracy of UK chamber facilities used in 
measuring methane emissions from livestock. Meas. J. Int. Meas. Confed. 66:272-279. doi:10.1016/j.measurement.2015.02.029.

Garnett, E.J. 2012. Evaluation of the greenfeed system for methane estimation from grazing dairy cows. Master Sci. Anim. Massey Univ. Nouv. Zélande 157.

Garnsworthy, P.C., J. Craigon, J.H. Hernandez-Medrano, and N. Saunders. 2012. Onfarm methane measurements during milking correlate with total methane production by individual dairy cows. J. Dairy Sci. 95:3166-80. doi:10.3168/jds.2011-4605.

Goodrich, J.K., E.R. Davenport, M. Beaumont, M.A. Jackson, R. Knight, C. Ober, T.D. Spector, J.T. Bell, A.G. Clark, and R.E. Ley. 2016. Genetic Determinants of the Gut Microbiome in UK Twins. Cell Host Microbe 19:731-743. doi:10.1016/j.chom.2016.04.017.

Goodrich, J.K., J.L. Waters, A.C. Poole, J.L. Sutter, O. Koren, R. Blekhman, M. Beaumont, W. Van Treuren, R. Knight, J.T. Bell, T.D. Spector, A.G. Clark, and R.E. Ley. 2014. Human genetics shape the gut microbiome. Cell 159:789-799. doi:10.1016/j.cell.2014.09.053.

Goopy, J.P., C. Chang, and N. Tomkins. 2016. A Comparison of Methodologies for Measuring Methane Emissions from Ruminants. T.S. Rosenstock, ed. Springer International Publishing.

Goopy, J.P., R. Woodgate, A. Donaldson, D.L. Robinson, and R.S. Hegarty. 2011. Validation of a short-term methane measurement using portable static chambers to estimate daily methane production in sheep. Anim. Feed Sci. Technol. 166-167:219-226. doi:10.1016/j.anifeedsci.2011.04.012.

Graham, S.R., S.A. Dalzell, N.T. Ngu, C.K. Davis, D. Greenway, C.S. McSweeney, and H.M. Shelton. 2013. Efficacy, persistence and presence of Synergistes jonesii in cattle grazing leucaena in Queensland: On-farm observations pre- and post-inoculation. Anim. Prod. Sci. 53:1065-1074. doi:10.1071/AN12301.

de Haas, Y., J.J.J. Windig, M.P.L.P.L. Calus, J. Dijkstra, M. de Haan, a. Bannink, R.F.F. Veerkamp, M. De Haan, a. Bannink, and R.F.F. Veerkamp. 2011. Genetic parameters for predicted methane production and potential for reducing enteric emissions through genomic selection.. J. Dairy Sci. 94:6122-34. doi:10.3168/jds.2011-4439.

Haber, M., J. Gao, and H.X. Barnhart. 2010. Evaluation of Agreement between Measurement Methods from Data with Matched Repeated Measurements via the Coefficient of Individual Agreement.. J. Data Sci. 8:457-469.

Hamlett, A., L. Ryan, and R. Wolfinger. 2004. On the use of PROC MIXED to estimate correlation in the presence of repeated measures. Proc. TwentyNinth Annu. SAS Users Gr. Int. Conf. Paper 198-:1-7.

Hammond, K.J., L.A. Crompton, A. Bannink, J. Dijkstra, D.R. Yáñez-Ruiz, P. O’Kiely, E. Kebreab, M.A. Eugenè, Z. Yu, K.J. Shingfield, A. Schwarm, A.N. Hristov, and C.K. Reynolds. 2016. Review of current in vivo measurement techniques for quantifying enteric methane emission from ruminants. Anim. Feed Sci. 
Technol. 219:13-30. doi:10.1016/j.anifeedsci.2016.05.018.

Hammond, K.J., D.J. Humphries, L. a. Crompton, C. Green, and C.K. Reynolds. 2015. Methane emissions from cattle: Estimates from short-term measurements using a GreenFeed system compared with measurements obtained using respiration chambers or sulphur hexafluoride tracer. Anim. Feed Sci. Technol. 203:41-52. doi:10.1016/j.anifeedsci.2015.02.008.

Hanneman, S.K. 2008. Design, Analysis and Interpretation of Method-Comparison Studies. Adv. Crit. Care 19:223-234. doi:10.1097/01.AACN.0000318125.41512.a3.Design.

Haque, M.N., H.H. Hansen, I.M.L.D. Storm, and J. Madsen. 2017. Comparative methane estimation from cattle based on total $\mathrm{CO} 2$ production using different techniques. Anim. Nutr. 3:175-179. doi:10.1016/j.aninu.2017.04.004.

Hartnack, S. 2014. Issues and pitfalls in method comparison studies. Vet. Anaesth. Analg. 41:227-232. doi:10.1111/vaa.12143.

Hazel, L.N. 1943. The Genetic Basis for Constructing Selection Indexes.. Genetics 28:476-490.

Hellwing, A.L.F., P. Lund, J. Madsen, and M.R. Weisbjerg. 2013. Comparison of enteric methane production predicted from the $\mathrm{CH} 4 / \mathrm{CO} 2$ ratio and measured in respiration chambers. Adv. Anim. Biosci. 4:6077-6085.

Hristov, a N., J. Oh, F. Giallongo, T. Frederick, M.T. Harper, H. Weeks, a F. Branco, W.J. Price, P.J. Moate, M.H. Deighton, S.R.O. Williams, M. Kindermann, and S. Duval. 2016. Short communication: Comparison of the GreenFeed system with the sulfur hexafluoride tracer technique for measuring enteric methane emissions from dairy cows.. J. Dairy Sci. 5461-5465. doi:10.3168/jds.201610897.

Hristov, A.N., E. Kebreab, M. Niu, J. Oh, A. Bannink, A.R. Bayat, T.M. Boland, and A.F. Brito. 2018. Symposium review : Uncertainties in enteric methane inventories, measurement techniques, and prediction models 1 6655-6674. doi:10.3168/jds.2017-13536.

Huhtanen, P., E.H. Cabezas-Garcia, S. Utsumi, and S. Zimmerman. 2015.

Comparison of methods to determine methane emissions from dairy cows in farm conditions. J. Dairy Sci. 98:3394-3409. doi:10.3168/jds.2014-9118.

Huttmann, H., E. Stamer, W. Junge, G. Thaller, and E. Kalm. 2009. Analysis of feed intake and energy balance of high-yielding first lactating Holstein cows with fixed and random regression models. Animal 3:181-188. doi:10.1017/S175173110800325X.

ISO. 1994. Accuracy (trueness and precision) of measurement methods and resultsPart 1: General principles and definitions. Geneva.

Johnson, K.A., and D.E. Johnson. 1995. Methane emissions from cattle.. J. Anim. Sci. 73:2483-2492. doi:10.2527/1995.7382483x.

Kennedy, B.W., J.H.J. Van Der Werf, and T.H.E. Meuwissent. 1993. Genetic and 
Statistical Properties of Residual Feed Intake' 3239-3250.

Kittelmann, S., C.S. Pinares-Patiño, H. Seedorf, M.R. Kirk, S. Ganesh, J.C. McEwan, and P.H. Janssen. 2014. Two different bacterial community types are linked with the low-methane emission trait in sheep. PLoS One 9:1-9. doi:10.1371/journal.pone.0103171.

Koch, R.M., L.A. Swiger, D. Chambers, and K.E. Gregory. 1963. Efficiency of feed use in beef cattle. J. Anim. Sci.

Lassen, J., and P. Løvendahl. 2016. Heritability estimates for enteric methane emissions from Holstein cattle measured using noninvasive methods. J. Dairy Sci. 99:1959-1967. doi:10.3168/jds.2015-10012.

Lassen, J., J.R. Thomasen, R.H. Hansen, G.G.B. Nielsen, E. Olsen, P.R.. Stentebjerg, N.W.H. Hansen, and S. Borchersen. 2018. Individual measure of feed intake on in-house commercial dairy cattle using 3D camera system. Page in Proceedings of the World Congress on Genetics Applied to Livestock Production, 11., Auckland.

Li, B., W.F. Fikse, J. Lassen, M.H. Lidauer, P. Løvendahl, P. Mäntysaari, and B. Berglund. 2016. Genetic parameters for dry matter intake in primiparous Holstein, Nordic Red, and Jersey cows in the first half of lactation. J. Dairy Sci. 1-8. doi:10.3168/jds.2015-10669.

Lu, Y., M.J. Vandehaar, D.M. Spurlock, K.A. Weigel, L.E. Armentano, C.R. Staples, E.E. Connor, Z. Wang, N.M. Bello, and R.J. Tempelman. 2015. An alternative approach to modeling genetic merit of feed efficiency in dairy cattle. J. Dairy Sci. 98:6535-6551. doi:10.3168/jds.2015-9414.

Lu, Y., M.J. Vandehaar, D.M. Spurlock, K.A. Weigel, L.E. Armentano, C.R. Staples, E.E. Connor, Z. Wang, M. Coffey, R.F. Veerkamp, Y. de Haas, and R.J. Tempelman. 2016. Modeling genetic and nongenetic variation of feed efficiency and its partial relationships between component traits as a function of management and environmental factors. J. Dairy Sci. 0:26002605. doi:10.3168/jds.2016-11491.

Madsen, J., B.S. Bjerg, T. Hvelplund, M.R. Weisbjerg, and P. Lund. 2010. Methane and carbon dioxide ratio in excreted air for quantification of the methane production from ruminants. Livest. Sci. 129:223-227. doi:10.1016/j.livsci.2010.01.001.

McBride, G.B. 2005. A proposal for strength-of-agreement criteria for Lin's Concordance Correlation Coefficient..https://www.medcalc.org/download/pdf/McBride2005.pdf [Accessed 01July2018].

McGinn, S.M., K. a. Beauchemin, a. D. Iwaasa, and T. a. McAllister. 2006. Assessment of the Sulfur Hexafluoride (SF) Tracer Technique for Measuring Enteric Methane Emissions from Cattle. J. Environ. Qual. 35:1686. doi:10.2134/jeq2006.0054.

Montanholi, Y.R., B.A. Smith, and S.P. Miller. 2016. Circadian characterization of 
thyroid hormones, methane and heat production profiles across physiological stages in replacement beef heifers. Page in 6th International Greenhouse Gas and Animal Agriculture conference, Melbourne, Australia.

Mrode, R.A., 2003. Linear models for the prediction of animal breeding values. Cabi.

Münger, a., and M. Kreuzer. 2008. Absence of persistent methane emission differences in three breeds of dairy cows. Aust. J. Exp. Agric. 48:77-82. doi:10.1071/EA07219.

Muñoz, C., T. Yan, D.A. Wills, S. Murray, and A.W. Gordon. 2012. Comparison of the sulfur hexafluoride tracer and respiration chamber techniques for estimating methane emissions and correction for rectum methane output from dairy cows. J. Dairy Sci. 95:3139-48. doi:10.3168/jds.2011-4298.

Negussie, E., J. Lehtinen, P. Mäntysaari, A.R. Bayat, A.-E. Liinamo, E.A. Mäntysaari, and M.H. Lidauer. 2016. Non-invasive individual methane measurement in dairy cows. Animal 4:1-10. doi:10.1017/S1751731116002718.

Negussie, E., P. Mantysaari, E.A. Mantysaari, and M. Lidauer. 2014. Animal wise variation in enteric output traits and its relationship with feed efficiency in dairy cattle: a longitudinal model analysis. Pages $2-4$ in Proceedings 10 th WCGALP.

Niu, M., Kebreab, E., Hristov, A.N., Oh, J., Arndt, C., Bannink, A., Bayat, A.R., Brito, A.F., Boland, T., Casper, D. and Crompton, L.A., 2018. Prediction of enteric methane production, yield, and intensity in dairy cattle using an intercontinental database. Global change biology. 24:3368-3389.

Pinares-Patiño, C.S., S.H. Ebrahim, J.C. McEwan, K.G. Dodds, H. Clark, and D. Luo. 2011. Is rumen reterntion time implicated in sheep differences in methane emission? Pages 219-222 in Proceedings of the New Zealand Society of Animal Production.

Pinares-Patiño, C.S., S.M. Hickey, E. a Young, K.G. Dodds, S. MacLean, G. Molano, E. Sandoval, H. Kjestrup, R. Harland, C. Hunt, N.K. Pickering, and J.C. McEwan. 2013. Heritability estimates of methane emissions from sheep.. Animal 7 Suppl 2:316-321. doi:10.1017/S1751731113000864.

Ribeiro, G.O., D.B. Oss, Z. He, R.J. Gruninger, C. Elekwachi, R.J. Forster, W. Yang, K.A. Beauchemin, and T.A. McAllister. 2017. Repeated inoculation of cattle rumen with bison rumen contents alters the rumen microbiome and improves nitrogen digestibility in cattle. Sci. Rep. 7:1276. doi:10.1038/s41598-017-01269-3.

Robertson, A. 1959. The Sampling Variance of the Genetic Correlation Coefficient. Biometrics 15:469-485.

Rothschild, D., O. Weissbrod, E. Barkan, T. Korem, D. Zeevi, P.I. Costea, A. Godneva, I.N. Kalka, N. Bar, N. Zmora, M. Pevsner-Fischer, D. Israeli, N. Kosower, G. Malka, B.C. Wolf, T. Avnit-Sagi, M. Lotan-Pompan, A. Weinberger, Z. Halpern, S. Carmi, E. Elinav, and E. Segal. 2017. Environmental factors dominate over 
host genetics in shaping human gut microbiota composition. bioRxiv 555:150540. doi:10.1101/150540.

Roy, A. 2009. An application of linear mixed effects model to assess the agreement between two methods with replicated observations. J. Biopharm. Stat. 19:150-173. doi:10.1080/10543400802535141.

Sasson, G., S.K. Ben-shabat, and E. Seroussi. 2017. Heritable Bovine Rumen Bacteria Are Phylogenetically Related and Correlated with the Cow's Capacity To Harvest. MBio 8:1-12.

Savietto, D., D.P. Berry, and N.C. Friggens. 2014. Towards an improved estimation of the biological components of residual feed intake in growing cattle. J. Anim. Sci. 92:467-476. doi:10.2527/jas.2013-6894.

Spearman, C. 1904. The Proof and Measurement of Association between Two Things. Am. J. Psychol. 15:72-101.

Spurlock, D.M., J.C.M. Dekkers, R. Fernando, D. a Koltes, and a Wolc. 2012. Genetic parameters for energy balance, feed efficiency, and related traits in Holstein cattle.. J. Dairy Sci. 95:5393-402. doi:10.3168/jds.2012-5407.

Sutherland, T.M. 1965. The correlation between feed efficiency and rate of gain, a ratio and its denominator. Biometrics 21:739-749.

Tempelman, R.J., D.M. Spurlock, M. Coffey, R.F. Veerkamp, L.E. Armentano, K.A. Weigel, Y. de Haas, C.R. Staples, E.E. Connor, Y. Lu, and M.J. VandeHaar. 2015. Heterogeneity in genetic and nongenetic variation and energy sink relationships for residual feed intake across research stations and countries.. J. Dairy Sci. 98:2013-26. doi:10.3168/jds.2014.8510.

Thomasen, J.R., J. Lassen, G. Gunnar, B. Nielsen, and C. Borggard. 2017. Individual cow identification in a commercial herd using 3D camera technology. Page in Proceedings of theWorld Congress on Genetics Applied to Livestock Production,.

Veerkamp, R.F., and G.C. Emmans. 1995. Sources of genetic variation in energetic efficiency of dairy cows. Livest. Prod. Sci. 44:87-97. doi:10.1016/03016226(95)00065-0.

Veerkamp, R.F., J.E. Pryce, D.M. Spurlock, D.P. Berry, M.P. Coffey, P. Løvendahl, R. van der Linde, J. Bryant, F. Miglior, Z. Wang, M. Winters, N. Krattenmacher, N. Charfeddine, J. Pedersen, and Y. de Haas. 2013. Selection on Feed Intake or Feed Efficiency: A Position Paper from gDMI Breeding Goal Discussions. Interbull Bull.

Velazco, J.I., R.M. Herd, D.J. Cottle, and R.S. Hegarty. 2017. Daily methane emissions and emission intensity of grazing beef cattle genetically divergent for residual feed intake. Anim. Prod. Sci. 57:627-635. doi:10.1071/AN15111.

Velazco, J.I., D.G. Mayer, S. Zimmerman, and R.S. Hegarty. 2015. Use of short-term breath measures to estimate daily methane production by cattle. Animal 1-9. doi:10.1017/S1751731115001603.

Visscher, P.M. 1998. On the sampling variance of intraclass correlations and genetic 
correlations. Genetics 149:1605-1614.

Waghorn, G.C., and R.S. Hegarty. 2011. Lowering ruminant methane emissions through improved feed conversion efficiency. Anim. Feed Sci. Technol. 166167:291-301. doi:10.1016/j.anifeedsci.2011.04.019.

Wallén, S.E., M. Lillehammer, and T.H.E. Meuwissen. 2017. Strategies for implementing genomic selection for feed efficiency in dairy cattle breeding schemes. J. Dairy Sci. 100:6327-6336. doi:10.3168/jds.2016-11458.

Wolak, M.E., D.J. Fairbairn, and Y.R. Paulsen. 2012. Guidelines for estimating repeatability. Methods Ecol. Evol. 3:129-137. doi:10.1111/j.2041210X.2011.00125.x.

Wu, L., P.W.G. Groot Koerkamp, and N.W.M. Ogink. 2015. Design and test of an artificial reference cow to simulate methane release through exhalation. Biosyst. Eng. 136:39-50. doi:10.1016/j.biosystemseng.2015.05.006.

Wu, L., P.W.G.G. Koerkamp, and N. Ogink. 2018. Uncertainty assessment of the breath methane concentration method to determine methane production of dairy cows. J. Dairy Sci. 101:1554-1564. doi:10.3168/jds.2017-12710.

Yan, T., C.S. Mayne, F.G. Gordon, M.G. Porter, R.E. Agnew, D.C. Patterson, C.P. Ferris, and D.J. Kilpatrick. 2010. Mitigation of enteric methane emissions through improving efficiency of energy utilization and productivity in lactating dairy cows.. J. Dairy Sci. 93:2630-2638. doi:10.3168/jds.2009-2929.

Zetouni, L., M. Kargo, E. Norberg, and J. Lassen. 2018. Genetic correlations between methane production and fertility, health, and body type traits in Danish Holstein cows. J. Dairy Sci. 101:1-8. doi:10.3168/jds.2017-13402.

Zhu, Z. 2016. Dynamics of rumen bacterial and archaeal communities in dairy cows over different lactation cycle stages. Aarhus University, 



\section{Acknowledgements}

The acknowledgements is an opportunity to thank all the many people who have contributed in different ways to this journey. As this is the most read section of any thesis (sometimes the only read section), I will do my best to thank as many of you as I can, but I believe there are far too many to fit into this short text.

The work completed over the last four years would not have been possible without the hard work, support and guidance of my supervision team. In particular, my main supervisor Peter Løvendahl. There were many times the tasks to be completed seemed insurmountable, Peter would smile, break the task into smaller pieces, offer good suggestions and every time we found a solution. It is a pleasure to try to find new problems to challenge us. I was extremely fortunate to have co-supervisors Yvette de Haas and Jan Lassen, who launched the Cost Action Methagene network, which gave me vast opportunities to build a network, collaborations and much specialised training. Jan has the rare ability to innovate new research ideas, and then develop and implement them at break-neck speed keeping at the forefront of research and Yvette can navigate the worlds of research and politics with extreme efficiency, building networks of people and resources that make tackling climate change seem trivial. My promoter Henk Bovenhuis came into the project in the second phase and brought with him fresh a perspective and thoughtful comments which were invaluable in grounding me and bringing a higher quality to my research at the time it was most needed. It has been a privilege working with and learning from you all, I can only hope to emulate what I have seen you all achieve. Furthermore, I would like to thank all my co-authors from Denmark, The Netherlands and all over the world, we did some great work together. I would like to thank Martin Bjerring without whom much of the data I used would not be available. Come rain or snow, Martin was always willing to visit farms for gas sampling and always delivered the highest level of professionalism.

Thanks go to my colleagues at QGG Aarhus University for a pleasant and extremely stimulating work environment - it was reassuring after some time to be able to follow the solving of mixed models equations Just, Gousheng, Per and Daniel were presenting. In particular, my PhD and EGS-ABG buddies Ahmed, Larissa, Palle, Kristian, Gabriel, Hadi, Andrew, Mesbah, Mette, Margot, Thin, Bea, Bingjie, Lise, Marcin and many more. Thanks for the great discussions, sharing of advice and listening to all the challenges I faced. Also to my colleagues at ABG Wageningen University, Mathijs, Juan, Pascal (and Anne), Rodrigo, Kasper, Jeremie, Mario, Aniek, Yvonne, Roel, Piter and Henry, the quantitative discussion group was one of the highlights of my week and the great fun we had at defence afterparty celebrations is something I sorely miss. Special mention must be made of the ladies I shared the office with: Sonia, Zih-Hua, Coralia, Maria, Jovana and Claudia. I enjoyed my time with you immensely - the support you showed me and Crystal was amazing and we loved discovering all Wageningen had to offer with you. You 
managed to keep the girl talk to an almost bearable level and I now have a greater appreciation for the effort that goes into choosing a dress for a defence. Grum, we started together four years ago. Since then we have followed nearly the same path between Denmark and The Netherlands, it has been a privilege going through the $\mathrm{PhD}$ with a friend like you every step of the way.

Elise Norberg and Peer Berg, I do not believe that two people who are not supervisors have ever contributed so much to a PhD. From loaning me furniture for my empty apartment, driving Crystal and I all the way to The Netherlands and then offering us to stay on your farm when we moved back to Denmark. Not to mention the continued support in our move to Norway. We cannot thank you enough, it has been an absolute pleasure and we will sorely miss looking after the sheep. You started as my colleagues, landlords and ended as our dear friends.

A very long list of school teachers put in a lot of hard work in my early years and I did not make it easy for them. I appreciate your hard work so much more now. Even though many will not be able to read this, special mention must be made of Mr Chris Allam, Mrs Cathy Schwartz and Mrs Bridget Fielding of Merrifield College and Mrs Sandra Remsing, Mr Wayne Rathbone, Mrs Louise Hoyle and Mr Lennard Viktor of Kingswood College. Your efforts made it possible for me to seize the opportunities. Dr Colleen Hepburn and Prof. Dr. Randal Hepburn you made every effort to introduce me to the word of academics at Rhodes University and showed me how rewarding a career in academia can be. My lecturers at Stellenbosch University in Biometry Mev Annalene Sadie and Mnr Theo Pepler who took special interest in me and nurtured my interest in biometry and statistics. Prof. Dr. Danie Brink who encouraged me to follow my interests and take an extra course or two in aquaculture and quantitative genetics, took a chance on accepting me for an MSc and then did all in his power to support me in taking the decision to do a PhD on the other side of the world. All you have taught me has lead me to the career of my dreams.

I would like to thank those who were there at the beginning and have contributed the most, my parents and family, after all they provided the $\mathrm{G}$ and the $E$ and possibly the $M$ (see chapter 5-6 to understand joke). More importantly your love and support. Few have been as privileged as me, I never wanted for anything, you have gotten me this far. To my mother Carolyn, thank you for being the best mother anyone could ask for, you taught me the value of a sharp mind and hard work even when the odds are stacked against you. To my father Clive, you taught me to use my head at a young age, never deceive yourself or others and to make up my own mind. When everyone else just accepts something as true, it is usually wrong. To Charles, you introduced me early in life to the wonders of the natural world and nurtured my love of farming and nature, which drives all the research I do. To my Nana Merle, you have always been there, looking after us and guiding us, I love you very much. To my brother Warwick and my sister Natalie, good luck topping this! Jokes aside, being your older brother has been a joy; it is the expectations you set for me which have motivated me. You have both already 
achieved so much, although we are spread all over the world I know we will always support each other.

Lastly and most certainly not least. My loving wife Crystal, you have supported me all these years and without your love, I would not be the person I am today. You gave me the strength to leave South Africa and I will forever be grateful to you for putting aside your career to come live all over the world with me because I would not have had the strength to stay away. Things became so much brighter, happier and easier after you came, without you, none of this would have been possible. You are the reason I strive to do better. You have read every manuscript, heard every presentation and probably know more about methane, microbes, genetics and statistics than any wife should. Wherever we end up in the world, we will thrive together, thank you my love.

Gareth Difford

August 2018 



\section{About the author}

Gareth Frank Difford was born 31 October 1988 in East London South Africa. He completed a B.S.c in Molecular Biology and Biotechnology from the Stellenbosch University, South Africa in 2010. During his bachelor he developed an interest in aquaculture and genetics. Shortly thereafter, he obtained a scholarship to study a master's degree in Genetics and Animal Breeding at Stellenbosch University, South Africa. The topic of research during his masters was selective breeding of the South African Abalone (Haliotis Midae), during which he developed a great appreciation for phenotyping, quantitative genetics and statistical methods. During the final year of his master's degree, he obtained an Erasmus Mundus Scholarship for a research exchange with the Katholieke Universiteit Leuven, Belgium during which he worked on genetic parameters for growth and carcass quality traits in the Flemish pig breeding program. This master's thesis resulted in the first genetic parameters for growth traits in South African abalone and was awarded cum laude in 2013. During University vacations and after his M.S.c, he worked as an assistant manager at a landbased recirculation facility in East London on Dusky Kob (Argyromomus Japonicus), which resulted in a collaborative research project and the first breeding program for the species. In 2014 Gareth Difford was awarded an Erasmus Mundus joint PhD scholarship between Aarhus University, Denmark and Wageningen Univeristy, The Netherlands. The PhD topic is 'Genetic control of Methane emissions, Feed efficiency and Metagenomics in Dairy Cattle' (This Thesis) defended 28 September 2018. After his PhD, he continues as a Researcher at Nofima, Norway working on phenomics and quantitative genetics in aquaculture species. 


\section{Peer review publications}

1. Vlok, A. C., Difford, G. F., Rhode, C., \& Brink, D. (2016). An Assessment of Hatchery Cohort Growth Rates of South African Abalone, Haliotis midae, Across Four Commercial Environments. Journal of the World Aquaculture Society, 47(5), 658-666.

2. Difford, G. F., Lassen, J., \& Løvendahl, P. (2016). Interchangeability between methane measurements in dairy cows assessed by comparing precision and agreement of two non-invasive infrared methods. Computers and Electronics in Agriculture, 124, 220-226.

3. Difford, G. F., Vlok, A. C., Rhode, C., \& Brink, D. (2017). Heritability of growth traits in South African Abalone (Haliotis midae L.) using the 'internal reference' method. Aquaculture, 468, 451-457.

4. Zhu, Z., Noel, S. J., Difford, G. F., Al-Soud, W. A., Brejnrod, A., Sørensen, S. J., ... \& Højberg, O. (2017). Community structure of the metabolically active rumen bacterial and archaeal communities of dairy cows over the transition period. PloS one, 12(11), e0187858.

5. Shetty, N., Difford, G., Lassen, J., Løvendahl, P., \& Buitenhuis, A. J. (2017). Predicting methane emissions of lactating Danish Holstein cows using Fourier transform mid-infrared spectroscopy of milk. Journal of Dairy Science, 100(11), 9052-9060.

6. Zetouni, L., Difford, G.F., Lassen, J., Byskov, M. V., Norberg, E. \& Løvendahl, P. (2018). Is rumination time an indicator of methane production in dairy cows? Accepted. Journal of Dairy Science.

7. Difford, G. F., Løvendahl, P., Lassen, J., Guldbrandtsen, B., \& Sahana, G. (2018). Microbiability-new insights into (genetic) modelling methane emissions of cattle. In 11th World Congress on Genetics Applied to Livestock Production.

8. Zhu, Z., Kristensen, L., Difford, G. F., Poulsen, M., Noel, S. J., ... \& Højberg, O. (2018). Changes in rumen bacterial and archaeal communities over the transition period in primiparous Holstein dairy cows. Journal of Dairy Science, DOI: https://doi.org/10.3168/jds.2017-14366.

9. Løvendahl, P., Difford, G.F., Li, B., Chagunda, M.G.G., Huhtanen, P., Lidauer, M.H., Lassen, J., \& P. Lund. (2018). Selecting for improved feed efficiency and reduced methane emissions in dairy cattle (a review). Accepted. Animal. 
10. Difford, G.F., Plichta, D.P., Løvendahl, P., Lassen, J., Noel, S.J., Højberg, O., Wright, A.D.G., Zhu, Z., Kristensen, L., Nielsen, H.B., Guldbrandtsen, B., \& Sahana, G. (2018). Host genetics and the rumen microbiome jointly associate with methane emissions in dairy cows. Accepted. PLOS Genetics.

11. Sorg, D., Difford, G.F., Mühlbach, S., Kuhla, B., Swalve, H.H., Lassen, J., Strabel, T., \& Pszczola, M. (2018). Comparison of a laser methane detector with the GreenFeed and two breath analysers for on-farm measurements of methane emissions from dairy cows. Computers and Electronics in Agriculture, 153, 285-294.

\section{Conference proceedings, abstracts and presentations}

1. Difford, G.F., Lassen, J., \& Løvendahl, P. 2015. Genetically active dairy cows eat more feed and produce more milk but they are not more efficient. The 66 th Annual Meeting of the European Federation of Animal Science (EAAP). Vol. 21 The Netherlands: Wageningen Academic Publishers, 2015. p. 398398.

2. Difford, G.F., Lassen, J., \& Løvendahl, P. 2015. Disagreements on current time an overlooked source of noise? Cost Action Methagene Annual Meeting. Wageningen, The Netherlands.

3. Lassen, J., Difford, G.F., \& Løvendahl, P. 2015. Genetic approaches for methane mitigation strategies. The 66th Annual Meeting of the European Federation of Animal Science (EAAP). Vol. 21 The Netherlands : Wageningen Academic Publishers, 2015. p. 92-92.

4. Difford, G.F., Lassen, J., \& Løvendahl, P. 2016. Comparing equipment for recording enteric methane concentrations, carbon dioxide concentrations and their ratio in the breath of Danish Holsteins during automated milking. The 6th Greenhouse Gas and Animal Agriculture Conference (GGAA), Melbourne, Australia. (Poster).

5. Difford, G.F., Lassen, J., \& Løvendahl, P. 2016. Genes and microbes, the next step in dairy cattle breeding. Book of Abstracts of the 67th Annual Meeting of the European Association for Animal Production (EAAP). Wageningen Academic Publishers.

6. de Haas, Y., Pryce, J.E., Wall, E., McParland, S., Difford, G.F., \& Lassen, J. 2016. Genetic and genomic analyses of enteric methane emissions of dairy cattle. The 67th Annual Meeting of the European Association for Animal Production (EAAP). Wageningen Academic Publishers. 
7. Szalanski, M., Difford, G.F., Løvendahl, P., Lassen, J. 2016. Comparing methods to analyse raw, large-scale methane data. The 67th Annual Meeting of the European Association for Animal Production (EAAP). Wageningen Academic Publishers.

8. Difford, G.F., Løvendahl, P., Lassen, J., \& de Haas, Y. 2016. Case studies of sniffer comparisons in Denmark. Cost Action Methagene Annual Meeting. Padova, Italy.

9. Difford, G.F., de Haas, Y., Visker, M.H.P.W., Lassen, J., Bovenhuis, H., Veerkamp, R., \& Løvendahl, P. 2017. Do breath gas measurements hold the key to unlocking the genetics of feed efficiency in dairy cows? The 68th Annual Meeting of the European Federation of Animal Science (EAAP), Tallinn, Estonia. Vol. 23 2017. ed. Wageningen Academic Publishers, 2017. p. 184.

10. Szalanski, M., Kristensen, T., Difford, G.F., Løvendahl, P., \& Lassen, J. 2017. Methane emission in Jersey cows during spring transition from in-door feeding to grazing. The 68th Annual Meeting of the European Federation of Animal Science (EAAP). Vol. 23 2017. ed. Wageningen Academic Publishers, 2017. p. 148-148.

11. Shetty, N., Difford, G.F., Lassen, J., Løvendahl, P., \& Buitenhuis, A.J. 2017. Feasibility of FT-IR-milk spectra to predict methane emissions in danish lactating dairy cows. Abstract from 68th Annual Meeting of the European Federation of Animal Science (EAAP), Tallinn, Estonia. Vol. 23 2017. ed. Wageningen Academic Publishers, 2017. p. 199.

12. Difford, G.F. 2017. Extending method comparison theory to $\mathrm{CH} 4$ emission in animal science. Cost Action Methagene Annual Meeting, Caserta, Italy.

13. Difford, G.F., Løvendahl, P., Lassen, J., Guldbrandtsen, B., \& Sahana, G. 2018. Invited speaker: Microbiability - new insights into (genetic) modelling methane emissions of cattle. Proceedings of the World Congress on Genetics Applied to Livestock Production, Auckland, New Zealand: Volume Challenges - Environmental. Vol. 11 2018. 405.

14. Difford, G.F., Gebreyesus, G., Løvendahl, P., Buitenhuis, A. J., Lassen, J. Guldbrandtsen, B., \& G. Sahana. 2018. The 69th Annual Meeting of the European Federation of Animal Science (EAAP), Dubrovnik, Croatia. Vol. 23 2017. ed. Wageningen Academic Publishers, 2018. 
Individual Training Plan
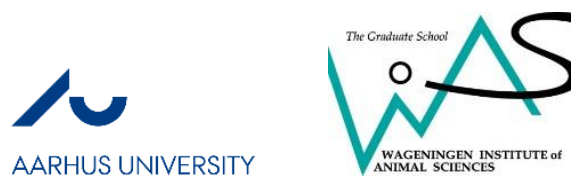

Mandatory courses (6 ECTS)

Year

Welcome to EGS-ABG

2014

EGS-ABG Summer Research School

2015

EGS-ABG Summer Research School

2018

Ethics course: Consequences of selection

2014

\section{Advanced Scientific courses (24 ECTS)}

Introduction to theory and implementation of Genomic Selection

2014

Methagene Training School - Methane Physiology for Geneticists

2014

Linear Models in Animal Breeding

2015

Gene Mapping

2015

Quantitative Genomics

2015

Methagene Training School - Rumen Microbial Ecosystem

2016

Methagene Training School - Breeding for complex traits

2017

Nova Course - Feed Efficiency in Dairy Cattle

2016

Professional Skills support courses (6 ECTS)

QGG research skills

2014

R programming for animal scientists

2015

\section{Dissemination of knowledge ( ECTS)}

\section{Teaching}

Teaching assistant - Methagene Training School: Large scale methane 2015

data handling, analysis and interpretation

Teaching assistant - Linear Models in Animal Breeding 2016

Teaching assistant - Population Genetics 2016

MSc supervision 2016

International conferences

Annual meeting of the European Federation of Animal Science (EAAP) $\quad 2015$ - 2018

Cost Action Methagene Annual Meeting

$2015-2017$

The 6th Greenhouse Gas and Animal Agriculture Conference (GGAA), 2016

World Congress on Genetics Applied to Livestock Production (WCGALP) 2018 


\section{Seminars and workshop}

Annual Gensap meeting

2015

Nordic Feed Efficiency in Nordic cattle (FUNC) annual meeting 2016

Nordic Cattle Meeting on Genomic Selection

2015, 2018 


\section{Colophon}

The research described within this thesis was financially supported by the European Commission with the framework of the Erasmus-Mundus joint doctorate 'EGS-ABG' and the REMRUM project funded by Innovation Fund Denmark (grant 11-105913).

The methane data used in Chapters 2,3,5 was collected in Denmark within the REMRUM project and additional metadata and pedigrees supplied by the Nordic Cattle Genetic Evaluation (NAV, Aarhus, Denmark). The methane data in Chapter 4 was from the REMRUM project Denmark, the Top Institute Food and Nutrition (TiFN) and Measuring individual methane project, The Netherlands. The Dutch pedigree and metadata was supplied by the cooperative cattle improvement organization CRV, the Netherlands.

The cover of this thesis was designed Crystal Difford.

This thesis was printed by Digisource, Viborg, Denmark 